\title{
The Uneven Development of Berlin's Housing Provision
}

Sabina Uffer

Thesis submitted to the Department of Geography and Environment of the London School of Economics and Political Science for the degree of Doctor of Philosophy, August 2011 


\section{Declaration}

I certify that the thesis I have presented for examination for the $\mathrm{PhD}$ degree of the London School of Economics and Political Science is solely my own work other than where I have clearly indicated that it is the work of others (in which case the extent of any work carried out jointly by me and any other person is clearly identified in it).

The copyright of this thesis rests with the author. Quotation from it is permitted, provided that full acknowledgement is made. This thesis may not be reproduced without the prior written consent of the author.

I warrant that this authorisation does not, to the best of my belief, infringe the rights of any third party. 


\begin{abstract}
Since the end of the 1990s, Berlin's housing has been described by a transformation from state- to market-led provision, creating more socially and spatially segregated neighbourhoods. The underlying processes exacerbating and reproducing these inequalities have however rarely been addressed. This thesis investigates the question how the transformation of Berlin's mode of housing provision generated particular forms of social and spatial inequalities. It begins from a state-focused approach to regulation theory and the related debate on the contemporary form of urban governance of the entrepreneurial city.
\end{abstract}

The thesis identifies three transformation processes of Berlin's mode of housing provision, which are informed by critical realist housing research. First, the privatisation of state-owned housing and the entrance of institutional investors; second, the reformation of the remaining state-owned housing companies and their adaptation to the government's social and economic demands; and third, the abandonment of supplyside subsidies for the construction and renovation of housing. The analysis of these three processes exposes how regulation, production, and consumption mechanisms play out under particular spatial and temporal circumstances, creating social and spatial inequalities. A particular emphasis lies on the production mechanisms defined through the diverging strategies of different institutional investors and state-owned housing companies.

The thesis concludes with a reflection upon the benefits of a critical realist methodology for analysing state restructuring. It is argued that only through the application of a critical realist methodology, the strengths of the regulation theory's conceptualisation of state transformation can fully be deployed. The thesis therefore goes beyond an affirmation of a more entrepreneurial mode of housing provision in Berlin, deploying a critical realist approach to reveal the underlying mechanisms of the particular mode of housing provision and its uneven consequences. 


\section{Acknowledgements}

This thesis grew out of the interest to understand why some neighbourhoods shrink while others grow and what the role of the state is in these processes of uneven development. The (ad)venture of investigating these questions would however not have happened without intellectual, financial, and moral support.

I would like to thank my supervisor Prof. Andy Pratt for the stimulating discussions, the detailed comments on my various draft versions, and the encouragement in some of the more difficult phases of the PhD endeavour. The motivation that came from the supervision meetings was invaluable. I am also very grateful for the comments I received from my second supervisor Dr. Murray Low. I would like to thank Prof. Ian Gordon for the critical questions and the inspiring discussions that followed. I received constructive comments from Prof. Michael Harloe. I would like to thank my colleagues who spent time to read and discuss this thesis, especially Dr. Nico van der Heiden, Andrew Watkins and Jayaraj Sundaresan. Additionally, I am grateful to the people commenting on the progress of my $\mathrm{PhD}$ when I presented at conferences and seminars. I would like to thank Tullia Marcolongo who proofread and edited the thesis.

A special thanks goes to the respondents of my interviews who showed great interest in the research project. The time they invested in answering my questions is highly appreciated.

The undertaking of this project would not have been possible without the financial support of the following institutions. The Swiss National Science Foundation (SNSF) supported my studies with a Fellowship for Young Researchers from June 2009 until September 2010. The Department of Geography and Environment of the London School of Economics and Political Science (LSE) supported me with Research Studentships Awards in 2008 and 2010. I also received a scholarship from the Swiss Association of Women in Academia (Schweizerischer Verband der Akademikerinnen). The teachers' organisation CLEVS in Switzerland contributed with a grant and made it therefore possible to start my studies. I would like to thank my parents Erika and Leza Uffer-Marthaler for their financial and moral support. And finally, I thank Jesse Rosenstock for his continuous support from the beginning to the end. 


\section{Content}

1 Introduction 10

1.1 “Poor, but Sexy”- Berlin's Urban Development 10

1.2 Regulating Uneven Development 13

$\begin{array}{lll}1.3 \text { Research Aim and Object } & 16\end{array}$

$\begin{array}{lll}\text { 1.3.1 Research Questions } & 17\end{array}$

$\begin{array}{lll}\text { 1.3.2 } & \text { Research Approach } & 17\end{array}$

1.3.3 Literature Review of Recent Research on Berlin 18

1.4 Chapter Outline 21

2 Uneven Development, Local Modes of Social Regulation, and the Entrepreneurial City 24

2.1 Uneven Development and the Role of the State 25

2.1.1 Regulation Theory 25

2.1.2 Role of the State Within Regulation $\quad 27$

2.1.3 Uneven Development and the Local Mode of Social Regulation 29

2.1.4 From Abstract to Concrete 32

2.2 The Entrepreneurial City 33

2.2.1 Increasing Importance of Cities 34

2.2.2 From Welfare to Economic Development 35

2.2.3 From Government to Governance 36

$\begin{array}{ll}2.2 .4 & \text { Social Inequality } \\ \end{array}$

2.3 The Entrepreneurial City, Uneven Development, and Housing Provision 38

2.3.1 Housing Provision within the Entrepreneurial City 40

2.3.2 Processes of Uneven Development: A Realist Approach 42

Conclusion 43

3 A Critical Realist Methodology $\quad 45$

3.1 Critical Realism 45

$\begin{array}{ll}3.2 \text { Causal Mechanisms of Housing Provision } & 47\end{array}$

3.2.1 Necessary Causal Relations $\quad 50$

3.2.2 Contingent Causal Relations $\quad 54$

3.3 Case Study Approach

3.3.1 Case Selection 56

3.3.2 Four Cases $\quad 58$

3.4 Fieldwork Process $\quad 62$

3.4.1 Semi-structured Interviews $\quad 62$ 
3.4.2 Participation in Conferences $\quad 67$

3.4.3 Document Collection $\quad 67$

3.5 Analysis of the Collected Data 68

$\begin{array}{lc}\text { Conclusion } & 69\end{array}$

4 Historical and Spatial Development of Berlin's Housing $\quad 70$

4.1 Late $19^{\text {th }}$-Century Block Developments

4.1.1 Sensitive Urban Renewal of Block Developments in West Berlin 75

4.1.2 Complete Abandonment of Block Developments in East Berlin 77

4.2 Twenties, Thirties, and Fifties Row Developments 79

4.2.1 Continuation of the Modern Style Row Developments in West Berlin 82

4.2.2 Socialist Realism Replaced Row Developments in East Berlin 83

$\begin{array}{lll}4.3 & \text { Post-war High-rise Developments } & 86\end{array}$

4.3.1 Three New High-rise Housing Estates in West Berlin 86

4.3.2 Large-scale High-rise Developments in East Berlin 89

4.4 Summary Illustrations of the Different Housing Types 91

$\begin{array}{ll}\text { Conclusion } & 93\end{array}$

5 Privatisation of State-owned Housing and Institutional Investors 96

5.1 Privatisation Encouraged Institutional Investors to Enter Berlin's $\begin{array}{lr}\text { Housing Market } & 97\end{array}$

5.2 Global Financial Market Mechanisms Directed Institutional Investors Towards Real Estate 102

5.3 Institutional Investors' Profit Speculation and the Reality of the Local and Global Market Conditions

5.3.1 Speculation on Capital Gain Based on Rising Demand for Use 106

5.3.2 Speculation on Capital Gain Based on Rising Demand for Investment 107

5.3.3 Local and Global Market Failures 109

5.4 Local and Global Market Failures Shaped the Strategies of Real Estate
Private Equity Funds

5.4.1 Two Types of Real Estate Private Equity Funds 111

5.4.2 Investment, Management, and Exchange of Value Added Funds 114

5.4.3 Investment, Management, and Exchange of Opportunistic Funds 123

Conclusion 131

6 Reformation of State-owned Housing Companies 134

6.1 Reformation Enabled Berlin's Government to Redefine the Aims of State-led Housing Provision $\quad 135$

6.2 Institutional Investors Created Competitive Market Conditions 141 
6.3 Guiding Principles and Competitive Market Conditions Shaped the Strategies of State-owned Housing Companies

6.3.1 Finance of State-owned Housing Companies 143

6.3.2 Investment, Management, and Exchange of State-owned Housing $\begin{array}{ll}\text { Companies } & 145\end{array}$

6.3.3 Differences Among State-owned Housing Companies 157

6.4 Synthesis of Privatised and State-owned Production Mechanisms 161

$\begin{array}{ll}\text { Conclusion } & 164\end{array}$

7 Abandonment of State Subsidies for Housing 166

$\begin{array}{lll}7.1 & \text { Abandonment of Subsidies for Social Housing } & 167\end{array}$

7.1.1 Production Mechanisms for Former Social Housing 170

7.1.2 Provision of Remaining Social Housing 176

7.1.3 Consumption of Social Housing 180

7.1.4 Synthesis of Key Mechanisms in Social Housing and Their Spatial
Outcomes

$\begin{array}{lll}7.2 & \text { Reconfiguration of Urban Renewal } & 187\end{array}$

7.2.1 Production Mechanisms of Urban Renewal Housing 188

7.2.2 Consumption of Urban Renewal Housing 200

7.2.3 Synthesis of Key Mechanisms in Urban Renewal Housing and Their
Spatial Outcomes

$\begin{array}{ll}\text { Conclusion } & 210\end{array}$

8 Conclusion $\quad 212$

8.1 Regulation Theory, the Role of the State, and Spatial Division of Labour $\quad 214$

8.2 The Entrepreneurial City Re-examined 215

8.3 Uneven Development Reviewed 220

8.4 Berlin's Urban Development Revisited 223

$\begin{array}{lll}8.5 & \text { Further Research } & 224\end{array}$

Conclusion 226

\begin{tabular}{lr} 
Appendices & $\mathbf{2 2 8}$ \\
\hline
\end{tabular}

$\begin{array}{ll}\text { Appendix } 1 \text { Interview List } & 229\end{array}$

Appendix 2 Interview Guideline (German) 231

Appendix 3 Conference List 234

Appendix 4 Document List

Appendix 5 Networks of the Data Analysis $\quad 238$

\begin{tabular}{ll} 
Bibliography & 243 \\
\hline
\end{tabular} 


\section{Figures}

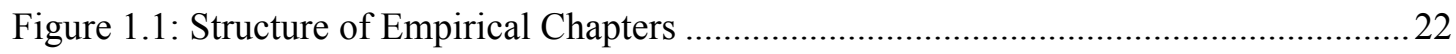

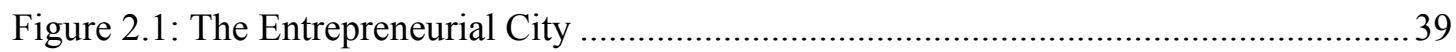

Figure 3.1: Structure of Causal Explanation for Processes of Uneven Development...............50

Figure 4.1: Distribution of the Housing Types Among Berlin's Districts (in \% of ha) ............92

Figure 5.1: Operational Structure of a Real Estate Private Equity Fund …………................. 106

Figure 5.2: Sold Housing Units in Berlin 1999-2000 .......................................................... 108

Figure 7.1: Base Rent Development of Social Housing (Euro/m² per Month) ....................... 178

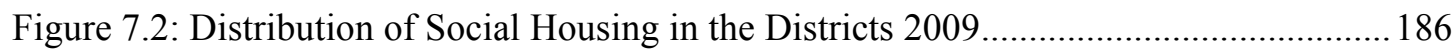

\section{Maps}

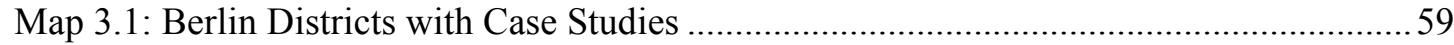

Map 4.1: Spatial Distribution of Different Housing Types in Berlin........................................72

Map 7.1: Current and Former Urban Renewal Areas in the Inner City of Berlin...................204

Map 7.2: Milieu Protection Areas and Restructuring Ordinance Area ...................................2.208

\section{Tables}

Table 2.1: Theoretical Framework from Abstract to Concrete ................................................25

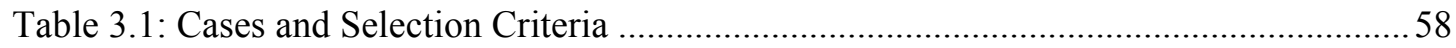

Table 5.1: Relative Importance of Strategies for Different Investors ....................................113

Table 6.1: Economic Position of State-owned Housing Companies Analysed ...................... 145

Table 6.2: Reduction of Personnel in Comparison to Reduction of Housing ......................... 150

Table 6.3: Key Production Mechanisms of Privatised and State-owned Housing................... 162

\section{Photos}

Photo 4.1: Bird's Eye View of a late 19th-Century Block Development with Side and Rear Wings (here Hackesche Höfe, Mitte).

Photo 4.2: Renovated Front Buildings in a late $19^{\text {th }}$-Century Block Development Neighbourhood (here Chamissoplatz, Kreuzberg)

Photo 4.3: Bird's Eye View of a Twenties Row Development (here Carl Legien Estate, Prenzlauer Berg, Constructed between 1928 and 1930) 
Photo 4.4: Bird's Eye View of Socialist Realist Housing in East Berlin Built

Between 1952 and 1960 (here Karl-Marx-Allee, Friedrichshain and Mitte).........84

Photo 4.5: Entity of Post-war High-rise Development (here Gropiusstadt, Neukölln).............87

Photo 4.6: Bird's Eye View of Prefabricated High-rise Developments in East Berlin (here, Marzahn, Marzahn-Hellersdorf) 


\section{Introduction}

\section{1 “Poor, but Sexy”- Berlin's Urban Development}

In 2003, a German magazine asked the Mayor of Berlin if money is sexy. He denied that money was sexy and gave Berlin as the perfect example to underline his point of view: "We are poor, but nevertheless sexy" (Frey 2003). This became a well-known Berlin slogan, advertising the city as extremely cheap but nevertheless or exactly because of it attractive. It also characterises, however, fairly well how Berlin developed after reunification: pretty unevenly. While economically under-performing and financially broke, Berlin became a global brand characterised as the "wild cultural metropolis" (Scharenberg and Bader 2009: 330).

Following reunification, the decision to re-establish Berlin as Germany's capital created expectations that the city could become another nodal point for the European or global economy and attract international headquarters to compete with Paris or London. Anticipating the transformation of Berlin (re-)gaining world city status, developers, expecting a growing demand for office and commercial space, considered the city as an excellent investment opportunity (Cochrane and Jonas 1999). This created, in the early 1990s, what Strom (2001: 7) called a "gold rush mentality". At the same time, Berlin's government invested heavily into the construction and modernisation of the city's housing stock, especially in East Berlin. The government promoted the construction of both new social and private housing with subsidies and tax deductions. Additionally, urban renewal strategies for the modernisation of Berlin's housing stock were extended to the neighbourhoods of East Berlin. The growth expectations for Berlin, however, were exaggerated, and the city soon struggled with increasing financial difficulties due to political, economic, and demographic changes.

While Berlin, both East and West, was highly subsidised during the Cold War, it lost its special status on the world stage that it had due to the two competing ideologies and therefore also lost the financial support from the national state and the occupying forces respectively. Furthermore, the population as well as the economy declined (Krätke and Borst 2000; Häußermann and Kapphan 2002). ${ }^{1}$ The population decline was partly due to an out-migration to other regions, especially to West Germany where more job opportunities could be found. It was, however, primarily due to an impressive suburbanisation process, which was only made possible through the fall of

\footnotetext{
${ }^{1}$ There was a short period at the beginning of the 1990 s when the population increased. However between 1994 and 2004, the population declined by 2.42 percent from 3.47 million to 3.39 million residents (Amt für Statistik Berlin-Brandenburg 2010).
} 
the Wall. The general demographic development and the in-migration, mostly from abroad, were not able to balance this out. And even though the population has been slightly growing in the last few years and is expected to continue to do so (Investitionsbank Berlin 2009: 16 et seq.), it has not returned to 1994 levels. Furthermore, it is not expected that the population will rise significantly in the near future.

This development was reinforced by an economic downturn. The selling of industrial enterprises of the former GDR to West German and western European companies induced a fast de-industrialisation process in East Berlin. At the same time, West Berlin's excessively subsidised industries and outdated economic structure collapsed after the discontinuation of state subsidies (Heeg 1998). The de-industrialisation and transformation process led to the loss of half a million industrial jobs that have been only partly replaced by service and creative industries (Droste and Knorr-Siedow 2007). ${ }^{2}$ Even though there has been a growth of jobs in these sectors, they were not emerging at the anticipated pace (Krätke 2001). The demographic decline and economic downturn also affected Berlin's housing market. Towards the end of the 1990s, the housing market was characterised as having a surplus. Berlin's housing market suddenly faced high vacancy rates. ${ }^{3}$ This led to a drastic decline in housing construction. ${ }^{4}$ The demographic and economic downward spiral also increasingly affected the city's fiscal revenue and budget. Berlin currently has a debt of around 60 billion Euros (Senatsverwaltung für Finanzen 2010c). ${ }^{5}$

From 2005 onwards, the downturn was at least temporarily halted. Statistics point to an economic recovery ( 3 percent growth of the GDP between 2005 and 2007) and a small population growth of 0.6 percent between 2005 and 2007 (Amt für Statistik

\footnotetext{
${ }^{2}$ See Seiler (1998) for a more detailed account of the economic crisis after reunification and how the government tried to address it.

${ }^{3}$ Vacancy rates are measured based on the use of electric metres. A dwelling is considered vacant if not in use for longer than six months. Between 2006 and 2008, the vacancy rate was stagnating at 5.7 percent. In 2009, it decreased to 5.5 percent (Investitionsbank Berlin 2010). There is however a debate on the accuracy of means for measuring vacancy rates and several respondents argued that the official vacancy rate is overestimated because part of the vacant housing stock is no longer inhabitable. See also Bangert et al. (2006) and Berliner Mieterverein (2009) for a discussion on measuring vacancy rates in Berlin. All respondents however agreed that there are parts of Berlin's housing market that are suffering relatively high vacancy rates.

${ }^{4}$ While from the early until the mid-1990s, approximately 12,000 housing units were built a year, only approximately 3,600 housing units a year were built between 2005 and 2008. This is approximately 0.2 percent of Berlin's housing stock with 1.89 million dwellings (Investitionsbank Berlin 2010). Because the new construction is so marginal, the present research almost completely neglects the construction side of the housing provision and focuses on the finance, investment, management, and exchange of the existing housing stock.

${ }^{5}$ In 2009, Berlin produced a GDP of 90.1 billion Euros (Amt für Statistik Berlin-Brandenburg 2009c).
} 
Berlin-Brandenburg 2009b). ${ }^{6}$ Berlin has also gained new popularity, attracting younger residents and artists because of the comparably low living costs. Reporting on a recent ranking of German cities by economists, a ZEIT online article was even titled "Berlin owns the future" (Endres 2010, author's translation). According to the study $^{7}$ quoted in the article, Berlin has all the essential features for a successful boom: a well educated population, an international orientation and good transport links. A closer look at the development within Berlin's twelve districts shows however that not all districts are equally gaining from this development. Some areas, especially the inner districts of former East Berlin have gained in popularity and value. In contrast, the outer districts of the city continue to suffer from the economic transformation. Different studies (Häußermann and Kapphan 2002; Krätke 2004) point to the fact that social polarisation is no longer necessarily observable between Berlin's eastern and western districts. It seems that the 'losers' of economic restructuring are increasingly the inner urban districts of West Berlin - the "traditional industrial workers' districts" (Krätke 2004: 61).

The short outline of Berlin's development since reunification shows that within the specific historical context, Berlin's transformation from manufacturing to service industries has been delayed. Whereas other industrialised cities have been adapting to global economic changes since the mid-1970s, Berlin continued to receive high subsidies (Heeg 1998) and did not need to adapt until the fall of the Wall. As Latham (2006a: 89) puts it, "[i]t is only since the fall of the Berlin Wall in 1989 that normal history has returned to Berlin". This raises the question to what extent does Berlin follow the path that other cities have been following since the end of the 1970s? How does Berlin reposition itself within a global context of increasing interurban competition? ${ }^{8}$ Are there similar patterns of increased social and spatial inequalities observable in other contemporary cities? How is the state regulating this uneven development? ${ }^{9}$

\footnotetext{
${ }^{6}$ Berlin's economic situation in 1999 was stagnating with a GDP growth rate of 0.5 percent. In 2003, the GDP contracted by -0.7 percent. The economy started only to take off again in 2005 with a growth rate of 2.1 percent (Statistisches Landesamt Baden-Württemberg 2009). However the unemployment rate only started to improve in 2007 from a very high level of 17.9 percent (Amt für Statistik Berlin Brandenburg 2007; Statistisches Landesamt Baden-Württemberg 2009) and the purchasing power of 16,908 Euros per person in 2008 is still below Germany's average of 18,734 Euros (IHK Berlin 2009). ${ }^{7}$ The Hamburgischen WeltWirtschaftsInstitut HWWI conducted the study (Endres 2010).

${ }^{8}$ In a review essay, Brenner (2002: 641) points to this gap in the literature on Berlin. He criticises Krätke and Borst (2000) and Häußermann and Kapphan (2002) for not providing theoretical interpretations "of the entrepreneurial, globalisation-oriented policy reorientation that has unfolded in Berlin's local state apparatus".

${ }^{9}$ While a majority of the studies on Berlin's urban development are concerned with the immediate post-reunification changes (see Prokla 1998; Scharenberg 2000; DISP 2004), this thesis focuses not on the immediate consequences of the reunification, but on the period between 1998 and 2008 and the question how Berlin developed beyond the immediate impact of the reunification process.
} 


\subsection{Regulating Uneven Development}

Uneven development as the unequal geographical pattern of economic and societal development has long been discussed within the discipline of Geography but also within other social sciences. ${ }^{10}$ The definition of uneven development that different places and scales develop at different speeds would, as Smith (1982: 142) points out, "barely deserve mention". However, studying the reasons for the production of a specific spatial pattern is what scholars have become interested in. Especially within critical geography, various approaches to account for uneven spatial patterns have been developed. Harvey (1982; see also Smith 1982; 1984), for example, argues that uneven development is a necessary condition of the capitalist system whereas capital moves through space seeking higher profitability, leaving behind older industrial regions in favour of more dynamic and innovative ones. ${ }^{11}$ In contrast to Harvey's structuralist view, Massey (1984; see also Massey 2004) argues that uneven development is a reflection of the unequal social relations within the economic system. The inequality between social groups and their respective function in the production process is reflected in the division of labour, which is spatially manifested. This means that different forms of production necessarily create a differentiated spatial pattern, because conditions for profit maximisation differ depending on the mode of production.

The present thesis uses as an initial approach a regulation theory that explores the role of the local state triggering processes of uneven development. Regulation theory (Aglietta 1976; Jessop 1990a) is an analytical framework that was originally applied to analyse the reproduction of the capitalist system during crisis periods. More recent generations of regulation theorists depart from the predominating economic concern, analysing such issues as the transformation of the state and the impact on the urban context. While regulation theory is a broad field that is continuously developed, this thesis is specifically concerned with a particular group of regulation theorists' interpretation of the local state and the uneven development of state regulation at the subnational level (Painter and Goodwin 1995; Peck and Tickell 1995). Integrating notions from Harvey and Massey, Peck and Tickell (1995: 27, original emphasis) argue

\footnotetext{
${ }^{10}$ Besides the discipline of Geography, economists have studied uneven development most famously. The new economic geography's understanding of uneven development is based on the Keynesian development economists (Myrdal 1960; Hirschman 1958/1988) who explained uneven development through the cumulative effects of advantages (democratisation, industrialisation, dominance in trade) of the western world over the less developed countries. This position was in contradiction to the neoclassical view that spatial disparities are only a result of external events like environmental disasters, war, or state interventions that contort market mechanisms, which would otherwise even out inequalities. However, newer neo-classical studies take into account positive external factors such as knowledge (see Wissen and Naumann 2008 for an overview).

${ }^{11}$ See also Harvey (2006) for other explanatory approaches to uneven spatial development and Wissen and Naumann (2008) for an extensive discussion of the conceptualisation of uneven development within a Marxist tradition.
} 
that "distinctive local modes of social regulation" represent different regulatory practices that lead to specific social relations. The basic argument of this strand of regulation theory thus claims that due to the different regulatory practices, on different scales and within different places, there is an uneven spatial development. Little has either then or later, however, been said on processes of uneven development within a specific place and time.

These abstract analytical categories of regulation theory mean however that more concrete research is needed in order to account for a specific spatial and temporal context (Duncan 1981). ${ }^{12}$ Regulation theorists and other urban scholars have investigated the current regulatory processes at the urban level under the concepts of neoliberalism (Tickell and Peck 1995) and urban entrepreneurialism ${ }^{13}$ (Harvey 1989; Jessop 1997b; Hall and Hubbard 1998). This strand of literature argues that the urban level has gained importance through a restructuring of state scales since the 1970s (Brenner 2004a). Accordingly, it is argued that the national state as a regulatory institution is increasingly 'hollowed out' (Jessop 1994a) in favour of supra- and sub-national bodies of regulation. Through the advancement of technology and communication infrastructure, and through a continuous deregulation and liberalisation by governments and international institutions (Castells 2000), the national state increasingly lost its capacity to regulate the economy within its own borders. At the same time, cities have come to play a strategic role in the global network of economic activities as the location for the key industries of finance and services (Friedmann 1986; Sassen 1991; Knox and Taylor 1995). Thus, cities are in a competition with one another for new investment and industries. In order to be able to maintain or establish a competitive position in this contest, cities have been developing "more active entrepreneurial strategies" (Leitner and Sheppard 1998: 286) to generate economic growth. These processes are combined with an increasing dominance of a political discourse promoting the free market.

Urban entrepreneurialism is defined here according to Painter (1998: 261) as "a shift in urban politics and governance away from the management of public services and the provision of local welfare services towards the promotion of economic competitiveness, place marketing to attract inward investment and support for the

\footnotetext{
${ }^{12}$ See section 2.1.4 for an elaboration of this argument.

${ }^{13}$ The terms entrepreneurial city or urban entrepreneurialism, which are used interchangeably, leave room for a lot of ambiguity. An entrepreneurial city can have different meanings, as for example, a place for entrepreneurial activity or a place with increasing entrepreneurialism among its residents (see Painter 1998 for a more complete list). It would be more useful to speak of urban governance dominated by economic and market dynamics. This thesis sticks, however, to the terms of entrepreneurial city and urban entrepreneurialism because these have become established concepts within the urban studies literature (Harvey 1989; Hubbard and Hall 1996; Leitner 1990).
} 
development of indigenous private sector firms". The entrepreneurial city is thus the neoliberal form of urban governance. Two shifts within the regulatory processes of the local state characterise the entrepreneurial city. On the one hand, there is a refocus from policies for the provision of public services to policies oriented towards the development of a business-friendly city. On the other hand, there is a reorganisation of the institutional structure of regulation, increasingly integrating nongovernmental agencies in the formulation and implementation of urban policies (MacLeod et al. 2003). On a more concrete level, urban entrepreneurialism includes activities such as place-marketing through cultural events, property-led (re-)development projects, and the promotion of knowledge-based industries through the creation of technology parks (Leitner and Sheppard 1998). In order to realise these state projects, governments increasingly rely on external agencies dissolving the boundaries between government and governance (Jessop 1997b). The local state's responsibilities are reduced to the role of a partner - often the one that takes on the risk - and facilitator in growth coalitions (Harvey 1989). Mostly, these partnerships are established without public legitimisation. Therefore, citizens' interests are often neglected or even overruled by the imperative to stay competitive. A consequence of these entrepreneurial strategies is an increasing spatial exclusion of the socially disadvantaged; either through processes of urban renewal, displacing local habitants (Marcuse 1986); or through exclusionary spaces from which the poor are ruled out (Katz 2001).

While there is an extensive literature on the entrepreneurial city, ${ }^{14}$ several authors (Hubbard and Hall 1996; Wood 1998; Ward 2003) have pointed out that there is still little understanding of the implications of these processes on the social and spatial inequalities ${ }^{15}$ within cities. This is foremost due to a lack of understanding of the uneven processes between the new forms of urban governance and the temporary outcomes of social and spatial inequalities. Thus, questions like what is it about the entrepreneurial city that creates these inequalities need to be addressed. Moreover, there is a need to understand the processes of uneven spatial development within the domain of the state's withdrawing from welfare provision.

\footnotetext{
${ }^{14}$ For a good overview on the different aspects of urban entrepreneurialism see Hall and Hubbard (1998).

${ }^{15}$ Social and spatial inequality is defined here as the historically relative social and spatial outcomes of uneven regulation, production, and consumption processes (compare Massey 1979).
} 


\subsection{Research Aim and Object}

It is exactly this shortcoming within regulation theory and the debate on urban entrepreneurialism that this thesis tackles. It addresses the question: How does a more entrepreneurial form of local governance create social and spatial inequalities. In order to answer this question, it is argued, one must investigate the particularities of a specific sector. This thesis, therefore, takes the re-regulation of Berlin's housing provision as its object of study. Its aim is to analyse the processes of uneven development caused through the reorganisation of Berlin's mode of housing provision. Thus, the thesis goes beyond the regulation theorists' claim that different regulatory systems at the sub-national level lead to an uneven development between places, but identifies the processes of uneven development of housing provision within a specific place.

The reorganisation of Berlin's housing provision serves here as an object of study for three reasons. First, housing is a good indicator to study processes of uneven development and its social and spatial inequalities. Housing is part of the built environment, therefore reflecting the value of different areas within a city. At the same time, the social status of the tenants reflects social-economic disparities within a neighbourhood. Second, having been strongly state-led for the last five decades, Berlin's mode of housing provision has recently undergone a major transformation process, which analytically can be identified as a more entrepreneurial form of housing provision. ${ }^{16}$ This makes it an excellent object to study Berlin's urban development and its uneven consequences. Third, the current mode of housing provision has led to protests and violence. Burning cars throughout the city have made the news across the country in recent years (see, for example, Kohlenberg 2010) and a website continues to count the Mercedes, BMWs etc. that get burned every couple of days (Anonymous Author 2010). ${ }^{17}$ The fact that inner city districts have come increasingly under pressure from investors has led to a battle between investors of luxurious apartments and anarchist groups who claim to resist gentrification processes. These anarchist groups have resorted to violent means by burning cars in order to discourage investors. The government of Berlin seems, at the same time, rather helpless. Analysing the particular mode of housing provision in Berlin therefore also contributes to current political debates.

\footnotetext{
${ }^{16}$ Harloe (1995: 2) argues that the domain of housing has never "taken a place alongside other significantly de-commodified aspects of social provision, such as health, education and income maintenance, as one of the central pillars of the welfare state", but remained in an ambiguous position, shifting between more and less de-commodified periods. Since Berlin's housing provision has, however, been highly state-led within the second part of the Twentieth century (see chapter 4), it is considered here as part of the German welfare system.

${ }^{17}$ According to the website (www.brennende-autos.de), over four cars were burnt down on average per week in 2009 (Anonymous Author 2010).
} 


\subsubsection{Research Questions}

Guided by the literature on the entrepreneurial city, the first research question is thus How has Berlin's mode of housing provision been reorganised? As mentioned, the literature on urban entrepreneurialism claims that the local state increasingly withdraws from the provision of social services in favour of economic development policies, trying to attract investment. These state activities are implemented by governance structures whereas the state is merely facilitating and co-ordinating private actors who are implementing market-oriented policies. Thus, one would expect a withdrawal of Berlin's government from the provision of housing. However, it is argued that there is more to the reorganisation of housing provision than a mere withdrawal from the state in favour of private capital; the state also integrates market mechanisms into state-led housing provision. The 'entrepreneurialisation' of Berlin's housing provision is thus a complex process, which has intended and unintended consequences. The thesis explores these different dimensions of Berlin's transformation to an entrepreneurial form of housing provision.

The second question, introducing the concept of uneven development within a specific place, is How does Berlin's provision of housing create processes of uneven development? The thesis thus analyses how the processes of reorganisation play out spatially. In the literature on urban entrepreneurialism, it is generally expected that the shift towards an entrepreneurial city cause the increasing inequalities that are assessed in urban areas throughout the world (Brenner and Theodore 2002). This thesis explores the connecting uneven processes between the shift towards an entrepreneurial city and increasing social and spatial inequalities. Importantly, the thesis goes beyond a confirmation of an uneven spatial outcome under the entrepreneurial city. Rather, through the focus on the specifics of the system of housing provision, it investigates the uneven development processes between the reorganisation and temporary forms of social and spatial inequalities.

\subsubsection{Research Approach}

In order to analyse the processes between the reorganisation of the mode of housing provision and the social and spatial inequalities, the thesis takes a critical realist approach. Based on this analytical specification, the thesis establishes causal relations between concepts of the mode of housing provision such as regulation, production, and consumption. ${ }^{18}$ Following a method of iterative abstraction, causal mechanisms are established through a dialogue between the abstract model and concrete observa-

\footnotetext{
${ }^{18}$ See section 3.1 for a discussion on critical realism and the specific approach that has been applied within this thesis.
} 
tion. This approach helps to understand the specific mechanisms of the mode of housing provision that create processes of uneven development, linking back to the question; what is it about the entrepreneurial form of housing provision that creates uneven spatial development?

Thus, the theoretical analysis is structured around the debates discussed above (see chapter 2). However, in order to establish the specific model of causal relations of the mode of housing provision (see section 3.2), the thesis borrows from an extensive literature on housing. ${ }^{19}$ Specifically, the meta-theoretical concept of the 'structure of housing provision' (Ball and Harloe 1992; Ball 1986, 1983) and Lawson's (2006) critical realist application of the structure of housing provision play an important role in organising the empirical research. The 'structure of housing provision' concept aims at an analysis that goes beyond "political explanation of the changes in housing policy" (Ball et al. 1988: 2), including not only the demand side of housing, but also the production side. Lawson (2006) refers more generally to the different institutionalactor relations influencing a particular mode of housing provision. These approaches, therefore, provide a useful starting point to address questions of processes beyond the policies of the local state. They identify the specific mechanisms of housing markets and financial regulations that equally influence the mode of housing provision. However, the 'structure of housing provision' is an analytical framework that needs "to be founded on implicit or explicit theories" (Kemeny and Lowe 1998: 163; see also Ball and Harloe 1992: 13). Thus, in order not to be trapped in an empirical analysis of housing, the structure of housing provision in the context of this research is used to bridge the gap between the theoretical debates on regulation and the empirical analysis of the particular mode of housing provision in Berlin.

\subsubsection{Literature Review of Recent Research on Berlin}

An analysis of the current state of the literature on Berlin shows that in the last decade, an increasing body of literature has tried to tackle questions regarding the city's urban development. The literature can be categorised along the debate of whether Berlin has become an entrepreneurial city and to what extent alternative paths have been sought and taken. However, only few studies have focused on housing, and they have foremost been in the context of gentrification.

\footnotetext{
${ }^{19}$ For a good overview on housing research, see Ball et al. (1988), Kemeny and Lowe (1998), or Lawson (2006).
} 


\section{Towards an entrepreneurial city?}

Studies (Cochrane and Jonas 1999; see also Cochrane and Passmore 2001;

Scharenberg 2000; Prokla 1998) that focus on place-making and re-imagining through redevelopment projects pointed to a business-friendly orientation of urban development policies, confirming a more entrepreneurial approach to urban governance. Analysing redevelopment processes such as those of the Friedrichstrasse, Potsdamerplatz or the Alexanderplatz in the mid-1990s, these authors showed how Berlin tries to recreate itself as a global city, taking on entrepreneurial policy strategies and reinforcing social division (Häußermann and Kapphan 2002; Krätke and Borst 2000). Marcuse (1998), referring specifically to the new buildings of the national government and the Potsdamerplatz, even argues that these redevelopment projects are an explicit demonstration of economic and political power and represent a return to authoritarianism. $^{20}$ The vision of a competitive city able to transform itself into a city for global finance and services remains the predominant discourse, despite the fact that all of these efforts have not resulted in great success (Heeg 1998). Consequences of this vision are increasingly repressive and exclusionary policies embedded, in a discourse oriented towards international competitiveness (Eick 1998; Heeg 1998). ${ }^{21}$

Studies on the gentrification process of inner city districts in former East Berlin have come to a similar conclusion regarding Berlin's transformation process. Bernt and Holm (2005; see also Levine 2004) studied the transformation and urban renewal process of Prenzlauer Berg using gentrification and displacement theories. They note that because of rent control and the remaining of substandard housing throughout the district, gentrification has been delayed. In their more recent account, however, Bernt and Holm (2009: 323) criticise how a more neoliberal policy orientation goes hand in hand with the acceptance of gentrification "as a 'normal' form or urban development" and is generally neglected by the political elite in Berlin (and increasingly also by urban scholars according to their account). Holm (2006) concludes that the abandonment of support programmes and a de-politisation of the urban renewal process has widely economised the transformation process. Thus, a transfer from publicfinanced renovations towards private-financed renovation since the mid-1990s has diminished the influence of Berlin's government and accelerated processes of gentrification causing displacement.

The transformation towards an entrepreneurial city has also been, at least partially, confirmed through studies analysing the institutional transformation processes within

\footnotetext{
${ }^{20}$ See Campbell (1999) and Häußermann (1999) for a reply to Marcuse's critique on the urban development of Berlin. And see Marcuse (1999) for a reply to the comments.

${ }^{21}$ See Eick (1998) for a discussion on the privatisation of security services.
} 
the context of these redevelopment projects (Lenhart 2001; Strom 2001). Applying urban regime theory (Stone 1989, 2004; Stoker 1995), Strom (2001) could not find a typical growth oriented coalition for the development of these sites. Due to the government's preoccupation with its own transformation immediately after reunification, Berlin's policy-makers were not capable of forming growth coalitions. Lenhart (2001; see also Lenhart 1998) finds nevertheless a substantial democratic deficit in the decision-making processes for the development projects at Friedrichstrasse and Alexanderplatz. Due to the political re-orientation towards a globally successful city, endogenous interests and citizen participation processes were completely overruled. Thus, while the involvement of private actors might not have been as coordinated as regime theory would expect, and private actors might not have played as big a role as predicted in the entrepreneurial city debate, the problem of legitimisation of local politics has been ascertained by these authors.

More recent studies (De Frantz 2006; Colomb 2007; Scharenberg and Bader 2009) on Berlin focus on cultural policy as a way to re-imagine Berlin. Especially the demolishment of the Palast der Republik, a symbolic building of the former GDR government and the reconstruction of the Stadtschloss, the residence of the Prussian Kings on the same site, led to enormous public and political debates. Stressing the historical and local political context, De Frantz (2006) argues that such symbolic cultural projects can serve as a mean to reposition the city within a global competition. At the same time, these symbolic projects also foster public debates that involve the formation of an alternative urban development model.

\section{Towards an alternative urban development model?}

Other studies (Colomb 2007; Scharenberg and Bader 2009; Bader and Scharenberg 2010), especially on the (sub-)cultural sector in Berlin, show that there is increasing resistance against urban entrepreneurial strategies. Latham (2006a, 2006b) emphasises that Berlin is still characterised as a refuge for alternative living and therefore could potentially take a different path towards urban development as opposed to an entrepreneurial one. Analysing one of the most recent development projects in Berlin, the 'Media Spree', Scharenberg and Bader (2009: 331) show that a successful urban movement can challenge the state's neoliberal strategies through political pressure. A coalition of cultural entrepreneurs and local residents managed to "turn a debate about urban space into political mobilization" and force a renegotiation of the development project. Colomb (2007: 308 et seq.) researched the public discourses surrounding the demolition of the 'Palast der Republik' and showed that there are points of resistance towards the "vision of a recreated Castle", which serves the economic growth strat- 
egies of the city and "would privatize a strategic inner city site". Local initiatives from artists were able to challenge, at least temporarily, the predominant discourse.

This thesis thus contributes to the debate on Berlin's urban development looking at the less extensively studied theme of the withdrawal from welfare provision, analysing the reorganisation process of Berlin's mode of housing provision within the last decade and identifying its uneven consequences.

\subsection{Chapter Outline}

As argued above, the thesis follows a method of iterative abstraction whereas causal mechanisms are understood through a process between a theorisation of the abstract model and concrete observation. ${ }^{22}$ However, for purposes of readability, the thesis follows a more traditional chapter structure cross-referencing the interaction between theory, method and empirical findings.

Chapter 2 outlines the theoretical debate of the specific regulation theory approach and the debate on the entrepreneurial city within which this thesis positions itself. It presents the regulation theory approach concerned with the concepts of a local mode of social regulation and uneven development. On a more concrete level of abstraction, the chapter then discusses the literature on urban entrepreneurialism, identifying its shortcomings for the analysis of the processes between the local state's transformation towards urban entrepreneurialism and the uneven spatial consequences. The chapter argues for a critical realist approach, focusing on the investigation of particular causal relations of a specific sector such as the system of housing provision.

Following the theoretical discussion, chapter 3 presents the philosophical and epistemological basis of the thesis. It establishes the conceptual model for the empirical analysis of Berlin's mode of housing provision. The model outlines, as a starting point for the empirical investigation, the internal causal relations of regulation, production, and consumption, as well as the external causal relations of time and space. The practical process of fieldwork, data collection, and data analysis are discussed in the second part of chapter 3 .

The empirical part is then structured in four chapters (see Figure 1.1). Chapter 4 analyses the spatial, institutional, physical, and social evolution of Berlin's mode of housing provision along the three most important types of housing; late $19^{\text {th }}$-century block developments; Nineteen Twenties, Thirties, and Fifties row developments; and post-

\footnotetext{
${ }^{22}$ See chapter 3 for a discussion on the philosophical and methodological grounds of this thesis.
} 
war high-rise developments. This chapter, therefore, provides the context within which current regulatory changes to the mode of housing provision has to be understood. By structuring the chapter along the spatial, institutional, physical and social differences between the three types of housing, the chapter thus raises the question how these characteristics play out under the particular mode of housing provision.

\section{Figure 1.1: Structure of Empirical Chapters}

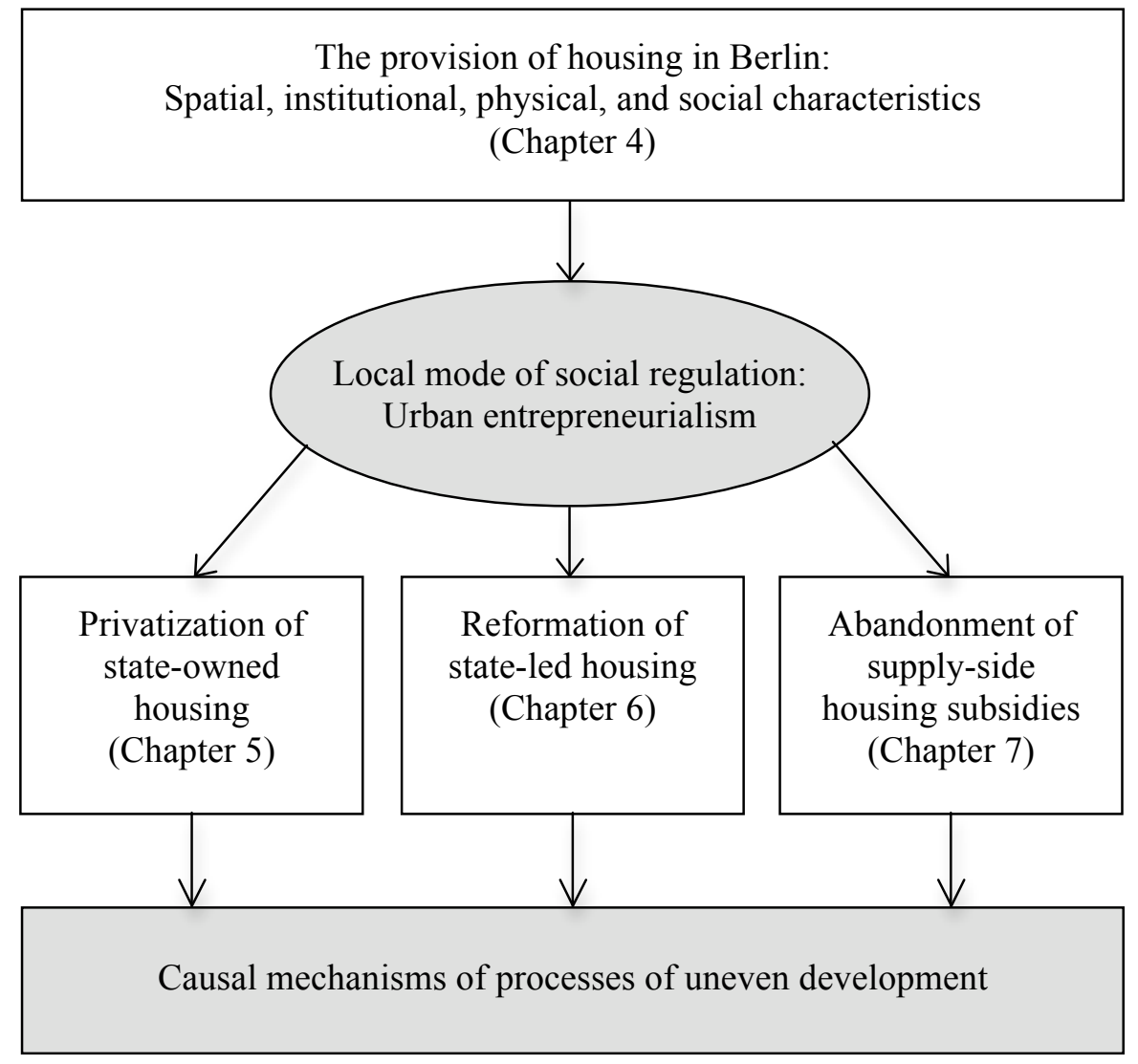

Chapters 5 to 7 analyse three specific processes of the reorganisation of Berlin's mode of housing provision and their respective causal mechanisms creating processes of uneven development. Chapter 5 analyses the privatisation of state-owned housing and the influence of institutional investment on Berlin's housing market. Within the global context of financial deregulation, the selling of state-owned housing has provided institutional investors an opportunity to enter Berlin's housing market. Chapter 5 investigates the strategies of two different types of investors and the consequences they have for the particular mode of housing provision. This chapter thus argues that it is not the privatisation of the state-owned housing per se, which created uneven development, but the particular way the government managed the privatisation. Moreover, 
it is the different production mechanisms of institutional investors under the state's regulatory conditions, which fosters the processes of uneven development.

Chapter 6 explores the reformation of the remaining state-owned housing companies. Facilitated through the national deregulation of non-profit housing companies, Berlin's government increasingly used state-owned housing companies for its financial benefit. This led to a reorientation of the state-led housing companies' strategies with uneven consequences. Chapter 6 therefore analyses the processes of Berlin's reformation of state-led housing and the strategies pursued by state-owned housing companies to fulfil the state's economic and social expectations. It argues that a more entrepreneurial form of housing provision is not a mere withdrawal of the state, but also includes complex processes of market mechanisms within state-led housing provision. Chapter 6 thus challenges the dualistic distinction between private- and state-led housing provision.

Chapter 7 investigates the specific regulatory conditions of social housing and urban renewal housing and the impact this has on the provision of housing structure. The government of Berlin decided to abandon the supply-side housing subsidies for social and urban renewal housing. The chapter analyses how the previously established agents of housing provision act under these specific regulatory conditions and argues that the state's particular way of abandoning the supply-side housing subsidies reinforce processes of uneven development.

In a concluding chapter 8 , the thesis refers back to the literature on regulation theory, the entrepreneurial city, and uneven development and argues how a critical realist approach to regulation theory helps to re-conceptualise these terms. Chapter 8 thus reemphasises the argument that only an investigation of the particular causal relations of the system of housing provision allows for an understanding of the uneven processes resulting from a move towards urban entrepreneurialism. The chapter addresses the consequences of the re-conceptualisation of the entrepreneurial city contributing to the debate on Berlin's urban development and ends with suggestions for future research. 


\section{Uneven Development, Local Modes of Social Regulation, and the Entrepreneurial City}

The empirical research of this thesis lies at the intersection of two theoretical approaches that contribute to the understanding of uneven development and of the reorganisation of the local state. Theory here is not used as a hypothetical model that is confirmed (or rejected) through empirical regularities. Rather, theory is understood here as the conceptualisation of empirical observations (see chapter 3). The process of conceptualisation is however not independent from previous concepts. Observation is therefore "theory-laden" (Sayer 1992: 83) whereas a system of concepts guides the empirical observation. By putting the conceptual system into a new situation, observation then either leads to the discovery of objects that have already been satisfactorily conceptualised or it leads to the discovery that changes the meaning of pre-existing concepts (Sayer 1992: 79); and some of the previous established concepts "may be part of the problem we are trying to escape" (Sayer 1992: 81). The aim of this chapter is thus to establish the concepts used around the reorganisation of the local state and uneven development and, via a sympathetic critique, to identify the shortcomings within the existing uses of the concepts (Sayer 1992: 81).

The first theoretical approach the thesis interacts with, is a reading of regulation theory that is concerned with the role of the state and the conceptualisation of uneven development at different regulatory state scales (Painter and Goodwin 1995; Peck and Tickell 1995). This theoretical debate provides a starting point for understanding the relation between economy and state regulation in a capitalist system (2.1). However, the position adopted in this thesis is that this literature remains at a level of abstraction that needs further concretisation for an analysis of regulatory processes within a specific time and place. The theoretical debate on the entrepreneurial city does help here (Harvey 1989; Jessop 1997b). Also based on foundations of regulation theory, the entrepreneurial city is viewed as the current regulatory practices at the urban level (2.2). Integrated into the neoliberal state, the entrepreneurial city is characterised by a policy shift and an institutional transformation increasingly creating forms of social and spatial inequalities.

There is however a shortcoming of the understanding between the reorganisation of the local state towards urban entrepreneurialism and the uneven development processes, which trigger social and spatial inequalities (2.3). Addressing this theoretical shortcoming, I propose a search for the causal relations between the processes of reorganisation within an entrepreneurial city (object) and processes of uneven spatial development (event) (Sayer 2000). Thus, the chapter adds a third level of abstraction: the particular mode of Berlin's housing provision. I argue that through an analysis of 
the causal mechanisms of the reorganisation of Berlin's system of housing provision processes of uneven development at the local state-level can be better understood and in turn, feed back into the more abstract levels of the entrepreneurial city and regulation theory. Table 2.1 illustrates the different levels of abstraction to clarify the analytical framework adopted in this thesis.

Table 2.1: Theoretical Framework from Abstract to Concrete

\begin{tabular}{|l|l|l|l|}
\hline Object & Regulation Theory & Entrepreneurial City & Berlin's Housing Provision \\
\hline regulation & $\begin{array}{l}\text { Different local modes of } \\
\text { regulation create uneven } \\
\text { development }\end{array}$ & $\begin{array}{l}\text { Entrepreneurial form of } \\
\text { urban governance creates } \\
\text { social and spatial inequali- } \\
\text { ties }\end{array}$ & $\begin{array}{l}\text { Current regulatory processes } \\
\text { at the local state level } \\
\text { uneusing provision processes with the } \\
\text { consequence of social and } \\
\text { spatial inequalities }\end{array}$ \\
\hline
\end{tabular}

\subsection{Uneven Development and the Role of the State}

Compared to other approaches for explaining uneven development within critical geography (see Harvey 1982, 2006; Massey 1984, 2004), the strand of regulation theory used in this work focuses on the role of the state. It is therefore considered the most useful perspective to understand the reorganisation of Berlin's state-led housing provision and its consequences. The following section first discusses the origins of regulation theory and then presents the specific interpretation used within this thesis.

\subsubsection{Regulation Theory}

Regulation theory was developed by French scholars (Aglietta 1976; Lipietz 1977; Boyer 1986) in opposition to neo-classical economics and structural Marxism. Contrary to the neo-classical economists' point of view that the economy is regulated through the market, regulation theorists integrate the economic with the extraeconomic. Thus, regulation theory analyses economic activities as socially embedded and regulated. The integrated relation of economic and extra-economic mechanisms are historically contingent. Economic development is therefore path-dependent (Aglietta 1978; Jessop 1997c). In opposition to structural Marxism, which is based on the automatic reproduction of capitalism towards its decline, regulation theorists argue that capitalism has to be regarded in stages whereas crisis play a "rejuvenating role" (Tickell and Peck 1995: 360; see also Jessop 1995b; 1997c). Regulation theory 
presumes that crisis is an intrinsic character of capitalism that can be stabilised through distinctive regulatory institutions (Painter and Goodwin 1995). In summary, regulation theory brings institutions back into political economy.

Two concepts of regulation theory are essential in understanding the stabilisation of capitalist accumulation through extra-economic institutions: The 'regime of accumulation' and the 'mode of regulation'. The 'regime of accumulation' refers to a period of time in which the conditions of production and consumption are balanced. The relatively stable convergence between the forms of production and consumption can however only occur through a distinctive set of social processes. These social processes are defined as the 'mode of regulation' (MacLeod 1997). The 'mode of regulation' is an ensemble of social, political, and economic institutions that help stabilise a regime of accumulation and therefore enable economic growth. The coupling between accumulation and regulation is the result of "chance discoveries" that are formed through social and political struggles (Lipietz 1987: 15). This 'institutional fix' of the coupling between accumulation and regulation is however only temporary and phases of relative stability are interrupted by periods of crises and regulatory restructuring (Peck and Tickell 1994). There are two opposing views regarding a particular institutional fix. On the one hand, Tickell and Peck (1995) claim that a particular (e.g. postFordist) mode of regulation is only found when uneven development is regulated and there is sustainable growth. ${ }^{23}$ Mayer (1994) then also sees in regulation theory's project the aim to test new modes of regulation against their effectiveness to balance uneven development and create sustainable growth. On the other hand, Painter and Goodwin (1995; see also Goodwin and Painter 1996) criticise this search for a new institutional fix as both teleological and functionalist. Instead of being concerned with the search for a new institutional fix, regulation theory is used as a tool to analyse ongoing processes of regulation. There is a constantly ongoing adjustment process between accumulation and its stabilising regulation, and it is relatively rare to stumble upon a stabilising mode of regulation. This is not a reason to abandon regulation theory, but to refocus research from a search for a new institutional fix to revealing regulatory processes and mechanisms. In accordance with Painter and Goodwin (1995), the thesis considers regulation theory as a tool to investigate the processes and mechanisms of regulatory change.

French regulation theorists (Aglietta 1976; Lipietz 1977; Boyer 1986) were preoccupied with the economic dimension of regulation. They were concerned with the

\footnotetext{
${ }^{23}$ Tickell and Peck (1995) oppose Jessop's (1994b) proposition of a Schumpeterian workfare state as a new mode of regulation replacing the Keynesian welfare state for reasons of increased social polarisation with the possible consequence of social instability and the growing threat of macro-economic crises.
} 
crisis of the Fordist regime of production and its corresponding mode of regulation, the Keynesian welfare state. The focus was on the regulation of the national economy (Aglietta 1976; Boyer 1986). In the past few decades, however, regulation theory has become more widely debated, especially within the disciplines of political economy, and urban and regional studies. Substantive critiques against the French school have evolved (MacLeod 1997) such as the neglect of the interaction of regulation at different scales (Brenner and Glick 1991) and the underdeveloped understanding of the processes behind regulatory changes (Painter and Goodwin 1995). Regulation theorists outside the French school have tried to address these critiques and have developed a research agenda directed towards the social dimensions of regulations. Incorporating different theoretical approaches such as Gramscian state theory (Jessop 1997a) or discourse analysis (Jessop 1997a), these regulation theorists are highlighting issues such as the state, space, and discourse. ${ }^{24}$

Regulation theory has been used in numerous fields of research and is continuously developing in exchange with other approaches, its main objective being a more institutionally grounded political economy (Peck and Tickell 1995). This thesis lies within later regulation theory approaches that depart from the predominating economic concern, but analyse such issues as the transformation of the local state and the impact of a local mode of social regulation on the spatial development. Regulation theory is therefore used to analyse regulatory processes at the local state level, such as political practices, strategies, and conflicts in order to reveal the processes of uneven development. The next two sections discuss in more detail the role of the state as the primary site for regulation (2.1.2) and uneven development between sub-national state levels caused by different local modes of social regulation (2.1.3).

\subsubsection{Role of the State Within Regulation}

The role of the state within regulation has been furthest developed through Jessop's strategic-relational approach (Jessop 1990b, 2007). Based on neo-Gramscian state theory, the strategic-relational approach ${ }^{25}$ focuses on the role of the state, taking into account the spatial and temporal specificities of institutions. The strategic-relational

\footnotetext{
${ }^{24}$ See Jessop (1997c) and MacLeod (1997) for a detailed account of the different critiques and developments within the regulation approach.

${ }^{25}$ Jessop, in what he calls a second phase of the strategic-relational approach, generalised the approach to "more general issues of structure and agency" (Jessop 2007: 38; Jessop 2005). Here however, I am concerned with the first phase of the strategic-relational approach that focused on the state and politics. This first phase of the strategic-relational approach was mainly elaborated in Jessop's book State Theory (1990b). Three main arguments are advanced: "First, the state system is the site of strategy. [...] Second, the state is also a site where strategies are elaborated. [...] Third, the structure and modus operandi of the state system can be understood in terms of their production in and through past political strategies and struggles" (Jessop 1990b: 260-2; see also Jessop 2007: 36-7).
} 
approach defines the state as integral, meaning as a complex relationship of political and social institutions. This conceptualisation of the state helps to understand uneven spatial development avoiding the structuralist trap (Jessop 2001; MacLeod and Goodwin 1999), because it emphasises the conflicts within regulatory processes and shows how these conflicts are resolved through the state.

The strategic-relational approach therefore claims that the state has to be analysed as a complex construction of social relations, which are guided by strategically selective institutions. The state is not able to manage the economy itself and hence must include different interest groups in the governing process. The state is a "site of struggle and contestation among diverse forces acting in and through the state" (Park 2008: 42). Thus, there is a conflict between different social interest groups that act through pre-existing institutions. The conflict is eventually resolved through a hegemonic project supported by an accumulation strategy. The hegemonic project involves the support of strategies that "explicitly or implicitly advance the long-term interests of the hegemonic class (fraction) and which also privileges particular 'economic-corporate' interests" (Jessop 1990b: 208; see also Jessop 1997a). The accumulation strategy is thus a specific model that enables economic growth. Jessop (1990b) admits that particular interests outside of the hegemonic project are integrated, especially in the interest of social cohesion. He argues however that these particular interests are cared for only in the short term in order to achieve longer-term goals of the hegemonic project. Thus, an accumulation strategy is important "in generating confidence in a hegemonic project as well as in the provision of the aspects of its social cohesion by letting material benefits, such as tax reductions and state subsidies flow to the social base, and by providing a high-quality infrastructure for economic growth including funding for scientific and technical education, worker retraining and research and development funds and centres" (Bertramsen et al. 1991: 114).

In order to implement a growth model, a state strategy is thus privileging the interests and access of key actors in formulating economic policy interventions. Institutions are therefore defined by a strategic selectivity ${ }^{26}$ because some institutions are more effective in achieving the state strategy (Bertramsen et al. 1991). The institutions are therefore necessarily specific in their geography and time. As Jessop (2001: 1227) puts it: "the structurally inscribed strategic selectivities of institutions are always and inevitably spatiotemporal and this in turn creates the space for both a geography of institutions and for a recognition of institutions as being, inter alia, geographical accom-

\footnotetext{
${ }^{26}$ In opposition to Offe's (1974) 'structural selectivity', which is defined by unequal access of interest groups (most often capitalist interests) based on better information and communication means, Jessop's 'strategic selectivity' defines the continuous reorganisation of the institutions privileging some interests over others.
} 
plishments". ${ }^{27}$ Furthermore, this means that the institutions of the state must be analysed as the outcome of past conflicts over state strategies (Jessop 1990b; Jessop et al. 2008), because "the present state form is [...] the product of the interaction between past patterns of strategic selectivity and the strategies currently adopted for their transformation" (MacLeod and Goodwin 1999: 517).

Thus, the strategic-relational approach helps to understand how new modes of regulation are established. The state is the principal site of negotiation for a new mode of regulation, based on hegemonic state projects and strategically selective institutions. The struggle for a new mode of regulation taking place through the state is, however, always based on past struggles. Therefore, the institutional context of the state matters for the negotiation of a new mode of regulation.

\subsubsection{Uneven Development and the Local Mode of Social Regulation}

Whereas early regulation approaches took space as a pre-given fact, ${ }^{28}$ third generation regulation theorists analyse the production of space, seeing space as the effect of the coupling between regime of accumulation and mode of regulation. Furthermore, there has been a shift from the analytical focus on the national state towards a more multiscalar analysis of regulation (Jessop 1997c). At first, the focus was on supra-national or sub-national scales of regulation. This new focus was related to the debate over the global-local relation (Swyngedouw 1992, 1997). On the one hand, the process of globalisation and the increasing importance of the European Union and other supranational institutions have highlighted the supranational scale. On the other hand, the observation that the local level regained importance in the accumulation process fostered research on the local level (Scott 1988; Amin and Robins 1990). This research came from an interest in the uneven development at the sub-national scale and the question why successful regional economies such as the Silicon Valley or the third

\footnotetext{
${ }^{27}$ For Jones (1997: 832), the integration of geography as the outcome of different path-dependent strategic selectivities that are specific to space and time is not sufficient. He introduces the concept of 'spatial selectivity' which "implies that the state has a tendency to privilege certain places within accumulation strategies, state projects, and hegemonic projects". Thus, the institutional setting of the state does not only privilege the access of certain interests over others but also certain places.

${ }^{28}$ Tickell and Peck (1995: 373) mention three things that early regulation theory had to say about space. First, the regime of accumulation and the mode of regulation vary between nation-states. Second, the coupling must be stabilised at the level of the nation-state. And third, uneven development is an intrinsic characteristic of capitalism. The authors point however to the lack of a conceptualisation of uneven development at the sub-national and supra-national level. See also Peck and Tickell (1995).
} 
Italy emerged. ${ }^{29}$ While these studies shed light on the reasons for specific successful industrial spaces, they overemphasised the agglomeration effect and missed out on the social mode of regulation (Tickell and Peck 1995; MacLeod 1997).

Other authors' (Peck and Tickell 1995; Jones 1997) ${ }^{30}$ attempts undertaken to understand the uneven development at the sub-national level are more valuable because they analyse the interaction of different regulatory scales and the effects they have on each other and on the uneven spatial development. The spatial dimension of regulation theory is thus addressed through an analysis of regional restructuring embedded in national and supra-national restructuring (Peck and Tickell 1995). In order to understand the social regulation of industrial districts and sub-national uneven development, Peck and Tickell (1995: 26 et seq.; see also Goodwin et al. 1993) argue for an integration of concepts such as Massey's (1984) 'spatial division of labour' or Harvey's (1985) 'structured coherence'. These concepts, they claim, provide a theoretical framework for an analysis of sub-national economic spaces as integrated entities in the wider context of global economic development. The spatial division of labour reflects the social relations within the production process. Similarly, structured coherence depicts a particular set of social relations playing out within a specific place.

Based upon these concepts, the local state is a necessary product of the division of capitalist production systems and its uneven development. Peck and Tickell (1995: 27, original emphasis) argue for the need to "explore the possibility that different regulatory functions may be sited at different spatial scales and that it may be possible to distinguish distinctive 'local modes of social regulation"'. Thus, the spatial division of labour creates a specific spatial division of the state with local modes of regulation. Different scales and different places have different modes of regulation depending on the specific conditions of the respective place. Uneven development therefore emerges due to diverging local modes of social regulation. Whereas Peck and Tickell (1995: 24 et seq.) argue that these local modes of regulation are the outcomes of the uneven development of capitalism and analyse the changing regulatory processes of

\footnotetext{
${ }^{29}$ Regulation theory has also been extensively used to analyse the transformation from a Fordist accumulation regime to a more flexible accumulation discussing such examples as the third Italy or Silicon Valley (Piore and Sabel 1984; Scott 1988; Storper and Scott 1992). This has however been widely criticised as "unsubstantiated empirical claims" because the literature fails to analyse how this new regime of flexible accumulation is socially embedded and regulated (Jones 1997: 831; see also Peck and Tickell 1995; Tickell and Peck 1995; MacLeod 1997). Regulation theorists that have been closest to the original French school, have emphasised that regulation theory is a method, a framework for the analysis of institutional transformation over space and time, and does not rest on the durability of postFordist models. In accordance with Jones (1997: 831; see also Peck and Tickell 1995), this research sees regulation theory as an ongoing research "whose strength rests on accounting for the operation and unevenly developed fabric of capitalism".

${ }^{30}$ See also Tickell and Peck $(1992,1995)$ and Chorianopoulos (2008).
} 
the national state affecting the local level, other authors (Duncan and Goodwin 1988: 41; see also Goodwin et al. 1993) attribute a stronger autonomy to the local state. In these accounts, the sub-national levels contribute to the differentiation of local modes of social regulation, and therefore to uneven development because of the local level's interpretative and representational roles. The local state transforms upper state level's strategies by interpreting them in a specific way. "These local spaces of regulation arise not only because of the uneven development of capitalist societies, but also because local agencies are often the very medium through which regulatory practices are interpreted and ultimately delivered" (Goodwin et al. 1993: 67). The interpretation of regulatory practices also depends on the local state's representational role, whereby the local state gives locally constituted groups that otherwise might be marginalised, access to state power (Duncan and Goodwin 1988: 41). Thus, the local government is seen as a possible agent to challenge the upper-level governments' hegemonic project.

Within this strand of regulation theory, uneven development is no longer seen as the mere effect of macro-economic transformation processes, from Fordist regimes of accumulation towards flexible accumulation, for example. Moreover, these regulation theorists (Duncan and Goodwin 1988; Goodwin et al. 1993) ${ }^{31}$ approach uneven development at the local scale as the effect of a restructuring that is also orchestrated through local institutions that act as regulatory agents. Uneven development at the sub-national level is therefore understood as the outcome of a sub-national coupling between a regime of accumulation and a local mode of social regulation. A local mode of social regulation is, however, not exclusively based on local regulatory practices. It is also characterised through the integration within national and global regulatory processes that are partly, but not exclusively, structured through local systems. The existence of local modes of social regulation then has two implications. First, the regulation is spatially unevenly developed at different scales, but also between different places. Second, local modes of social regulation result from an uneven development but also contribute to it. Local modes of regulation are a result of uneven spatial development, but reinforce it at the same time, because they can filter upper-level regulations in different ways.

\footnotetext{
${ }^{31}$ Duncan and Goodwin (1988) have written about the local scale as the result of national uneven development and as an agent for reinforcing uneven development.
} 


\subsubsection{From Abstract to Concrete}

Based on this strand of regulation theory, three aspects are crucial for the particular theoretical model that this thesis is founded upon. First, social regulation helps to reproduce capital accumulation. Therefore, there is a continuous struggle between the crisis tendency of capital accumulation and a form of social regulation that is capable of stabilising capital accumulation and enabling economic growth. Second, the struggle for new forms of social regulation takes place through a complex relationship of political and social institutions, which is defined as the state. The state, however, is based on previous struggles. Therefore, the historical institutional context of a specific mode of social regulation matters. Third, there are different social regulations within different places and scales, which leads to uneven development. However, uneven development also reproduces different local modes of social regulation. Thus, the historical spatial context of each locality equally matters.

In order to apply the above discussed concepts of regulation theory to a "specific historical process" (Duncan 1981: 231), there is however a need for more concrete concepts theorising current regulatory processes of the local state. The notion of local modes of social regulation that are represented through state strategies is not sufficient enough to understand specific processes of state intervention. As Duncan (1981: 235) points out: "[A]bstract analysis informs concrete research. But this explanation of actual state intervention can only be made to the extent that such a connection exists in itself, nothing can be deduced from such abstraction about the form, extent and nature of state intervention in any one society." Thus, there is a need for intermediate concepts that link the general categories of local mode of social regulation and uneven development to "specific historical relations of urban change" (Duncan 1981: 249).

Even though the historical relations of urban change can eventually be understood within the regulationist theory of capital accumulation, urban change at a given time depends on specific processes. Thus, in order to analyse the specific historical change of the reorganisation of Berlin's state-led housing provision and its regulatory and spatial consequences within the last decade, there is a need for intermediary concepts which refer to the current regulatory processes at the urban level. These intermediary concepts are drawn from the theoretical debate on the entrepreneurial city. 


\subsection{The Entrepreneurial City}

Continuing from a regulationist perspective, the current historical-specific form of regulatory processes at the local state level is referred to as the entrepreneurial city or urban entrepreneurialism. ${ }^{32}$ Scholars define urban entrepreneurialism in contrast to the pre-existing mode of urban managerialism (Harvey 1989; MacLeod 2002). Within the post-war Fordist-Keynesian system, the managerialist mode was concerned with "extending the provision of public services and decommodified components of welfare" (MacLeod 2002: 604) based on the national state's politics of redistribution. The oil shock in 1973, followed by a global recession, however, triggered a crisis of the Fordist-Keynesian coupling of accumulation and regulation. This transformed the global economy and the national welfare state (Lipietz 1994). With the breakdown of the Bretton Woods institutions that regulated the global financial flows and increasing financial deregulation (Smith 2002), national states were no longer able to protect their national economies. As a consequence, manufacturing industries relocated to countries with lower production costs (Dicken 2007). At the same time, major manufacturing regions in the US and Europe faced rapid decline (Beauregard 1993; Power and Mumford 1999).

While at the beginning of the 1970s, national states tried to adhere to their Keynesian state model grounded in redistributive regional policies, they increasingly faced financial difficulties. This led to a reorganisation of the Keynesian welfare state that dismantled the "entrenched managerial-welfarist framework of urban governance that had previously prevailed" (Brenner 2004b: 465). Within this reorganisation, national governments abandoned their redistributional policies and local governments were forced to adjust to this new fiscal austerity environment. Local governments sought new sources of income through economic development policies and entrepreneurial strategies. The entrepreneurial mode, in contrast to the managerialist mode, is thus "concerned with reviving the competitive position of urban economies" with the consequence of a "recommodification of social and economic life" (MacLeod 2002: 604).

Three processes characterise the entrepreneurial city. First, the entrepreneurial city has to be viewed within the context of cities' newly gained importance as motors of the national and global economy. Second, the entrepreneurial city shifts the priorities from the provision of welfare to the preoccupation with economic growth oriented policies. Third, the entrepreneurial city is characterised by an institutional transformation through a reorganisation of local governments towards new forms of governance, including non-state actors in policy formulation and implementation. These transfor-

\footnotetext{
${ }^{32}$ The regulatory processes at the urban level is defined here not solely through the city government's actions, but includes supra-national, national, and local state actions affecting the urban level.
} 
mation processes toward an entrepreneurial city go hand in hand with increasing inequality whereby large parts of the population are socially and spatially excluded. These processes are presented in more detail in the following sections.

\subsubsection{Increasing Importance of Cities}

Within the regulation approach, several authors have argued that the transformation of the Fordist-Keynesian system from the 1970s onwards has been accompanied by an institutional restructuring of the state in order to re-regulate the regime of accumulation (Jessop 1997b; Swyngedouw 1997; Brenner 1998, 2004a; Marston 2000). The restructuring of capitalism gives rise to a reorganisation and re-territorialisation of the state. Global economic processes such as the restructuring of production, the global deregulation of finance and trade, and advancements in technology and communication (Jones and MacLeod 1999) have undermined the national state's capacity to regulate and stabilise economic growth. Traditional production processes have been transformed and with it the importance of different places, scales and territory. Thus, the restructuring of capitalism during the Fordist crisis led to a reconfiguration of the regulatory capacities of the state: the national level lost some of its capacities downwards to the sub-national and upwards to the supra-national institutional level (Brenner 2004b). Within this transformation to a glocalised world (Swyngedouw 1992) the local, and especially the urban level, became more and more important in securing the local as well as the national economy.

Whereas earlier accounts of this process attributed the re-territorialisation of state responsibilities to global economic forces (Brenner 1998, 1999), later accounts integrate the role of the state as an agent in the re-scaling process. Jones and MacLeod (1999), for example, emphasise the role that the national state continues to play within this re-territorialisation. They argue that the national state continues to facilitate and promote regional and urban economic development. They promote an analysis that integrates the relationship of a state strategy with scalar governing capacities. Thus, the hollowing out of the national state is not just a simple down- and up-scaling, but rather a multidimensional process that depends on a specific state strategy. Similarly, Goodwin (2001), quoting Jessop (1995a), argues that even if economic forces have a direct influence on changes within urban politics, an analysis is needed of how these economic forces are translated into state strategies and how they are mediated and implemented through the state's strategically selective institutions. And Meyer (1995: 234-235) points to the fact that "most countries' central state (as well as EU) programmes have been put into place that encourage (in more or less coercive fashion) the emergence at the local / regional level of such developmental concepts and of the necessary institutional structures, often by tying their subsidies to the condition that 
the locality reach a consensus about the forms of cooperation among all the relevant actors". Thus, the national state fosters economic development policies through specific forms of market-oriented policy-making and subsidisation.

The transformation of the national state thus increases the competitiveness of cities. This growing inter-urban competition leads to a 'race to the bottom' (Peck and Tickell 1994: 281), whereas the same discursively constituted process that has led to marketoriented strategies at the national level is reproduced at the local level (Gordon 1999; Lever and Turok 1999; Peck 2002). Local regulatory and institutional change increasingly facilitates the access of private actors in order to secure foreign investment and increase local fiscal revenue. Cities enter into competition with one another and adopt entrepreneurial forms in order to establish themselves as "strategic nodal points within global and European financial networks" (Brenner 2004b: 469). This urban entrepreneurialism is characterised by specific state-projects and the reorganisation of the institutional setting of the local state. On the one hand, there has been a policy shift from welfare towards economic development oriented policies. On the other hand, there has been a parallel process of institutional transformation accompanied by new urban policy priorities.

\subsubsection{From Welfare to Economic Development}

There has been a shift from social welfare policies (i.e. education, health, housing) oriented towards improvement of citizens' well-being towards a preoccupation with policies focusing on economic growth (Harvey 1989; Meyer 1995; Hubbard and Hall 1996). The argument is that cities can better benefit from attracting financial capital and the mobilisation of the local economy than from provisions through the conventional welfare state (Hubbard and Hall 1996). This means urban decision-makers become more aware of "highly mobilized capital" and the necessity for their city to remain competitive in such a globalised world (Hubbard and Hall 1996: 159). As such, political decisions are based on the criteria of economic competitiveness. And state subsidies are aimed at industries that promise innovation and economic growth.

These growth oriented policies include the construction of large-scale development projects (Swyngedouw et al. 2002); ${ }^{33}$ the promotion of innovation (Porter 1998) and creative clusters (Florida 2003; Lee et al. 2004); the use of festive time strategies (Hughes 1999; Quinn 2005); or gentrification strategies (Smith 2002). These redevelopment policies are often linked to property speculation and fiscal incentives to

\footnotetext{
${ }^{33}$ Examples of these are the Guggenheim Museum in Bilbao (Gómez 1998), or the South Bank redevelopment in London (Baeten 2000).
} 
"guide the place and pace of the speculative activity" (Weber 2002: 537; see also Leitner 1990). Thus, local states are actively preparing the extraction of value by investors in order to facilitate capital accumulation. The entrepreneurial city promotes itself "in the global economy" (Meyer 1995: 234) using various means such as cultural and sport events. It tries to do two things: It seeks space to promote "marketoriented economic growth" and it creates places for "elite consumption practices" (Brenner and Theodore 2002: 368).

While promoting economic development policies, the entrepreneurial state is dismantling social welfare provision. This means that the local state withdraws from state support towards redistributional policies (Brenner and Theodore 2002), or applies market-oriented processes to these policy areas. Thus, the remaining domains of traditional welfare provision are deregulated, privatised and re-commodified (Jessop 1994a). The traditional responsibility of the local state to provide collective consumption goods has been abandoned (Meyer 1995; see also Jessop 2002) or integrated into the search for economic growth. Rather than continuing to support "allegedly unsustainable welfare expenditures", the state wants to create "enterprising subjects" (Jessop 2002: 459). This state strategy is embedded in new forms of institutional arrangements promoting these growth oriented interests.

\subsubsection{From Government to Governance}

In order to effectively achieve a business friendly environment, new institutional forms are needed to support the state strategy (Meyer 1995; Hubbard and Hall 1996; Jessop 2002). There is an increasing involvement of private agencies in the formulation and implementation of state policies. Specifically, economic development policies are shaped by public-private-partnerships involving business elites (Swyngedouw 2000). Thus, within "various policy fields where the local state used to be the exclusive service provider, non-governmental agencies have been upgraded or private markets have emerged" (Meyer 1995: 235). Government institutions are either abolished and left to market mechanisms, and public services such as policing are privatised leading to "a socially highly exclusive form of protection" (Swyngedouw 2000: 69).

This "market imperative" (Swyngedouw 2000: 69) leads to a "structural increase in the power of capital" that is no longer constrained through state regulation (Coleman et al. 2005: 2519, original emphasis). Without regulation, profit maximisation can be pursued untamed potentially leading to the exploitation of consumers and workers (Coleman et al. 2005). The market imperative also replaces democratic legitimacy. Political and business elites exclude the public from the decision-making process arguing that growth oriented strategies are necessary in order to remain regionally and 
internationally competitive (Swyngedouw et al. 2002). Additionally, nongovernmental agencies often compete for contracts and a multiplicity of private actors is getting involved in policy implementation. This leads, on the one hand, to depoliticisation and reduced transparency in policy implementation (Holm 2006: 316). On the other hand, economically powerful actors are privileged (strategically selected), because they are considered as the only ones capable to foster economic growth. These local non-elected agencies that are mandated to provide more efficient policy outcomes lack democratic legitimacy and are not accountable to the people (Tickell and Peck 1996). This creates a crisis of democratic participation. Without any governmental management, these agencies work outside of the public realm.

\subsubsection{Social Inequality}

Little has been said so far on the consequences of urban entrepreneurialism on the socio-spatial development. The restructuring of the economy combined with the dismantling of the welfare state has left large parts of the population unemployed and poor (Katz 2001; Rodriguez et al. 2001; MacLeod 2002). Through entrepreneurial state strategies, this stratum of the population is increasingly socially, but also spatially excluded. Harvey (1989) defines these entrepreneurial policies as a state strategy that is concerned with place rather than territory, because redevelopment projects are often targeted at "tourists and place-mobile capitalists" (MacLeod 2002: 605), but not planned for the urban citizenry. There are two forms of such exclusionary spaces.

Spaces become more exclusionary through strategies of gentrification (Smith 1982, 1996). Cycles of devalorisation of capital invested in the built environment followed by cycles of revalorisation through new investment create an uneven urban structure. These processes are often accompanied by "transitions in the tenure arrangements, occupancy, and physical condition of properties in a neighbourhood" (Smith 1982: 147). This upgrading of neighbourhoods is increasingly within the purview of publicprivate-partnerships, and the capital invested is increasingly global (Smith 2002). Investments in former derelict neighbourhoods and an increase in land use values create different forms of displacement. Marcuse (1986) distinguishes these forms of displacement as direct displacement, exclusionary displacement, and displacement pressure. Direct displacement is defined as forced displacement due to physical reasons such as lack of maintenance, or economical reasons like increasing rent levels. In contrast to direct displacement, exclusionary displacement prevents specific households to move into an area for economic reasons. Displacement pressure is defined as the impact on a household due to a dramatically changing neighbourhood. For example, when stores go out of business, the social network is lost or facility structures change (Marcuse 1986). 
Spaces become however also more exclusionary through new forms of social control. Places that are "seemingly public but actually private spaces" (Sibley 1995: xi) like gated communities, shopping malls, or redeveloped public plazas are ridden from undesirables like the homeless, often through private security firms. There is thus a combination of specific securitised architecture, legal measures, and 'zero tolerance' policing that regulates the use of space (Smith 1996; MacLeod 2002). "Concerned with [...] making urban centres attractive to both footloose capital and to the footloose middle classes, politicians and managers of the new economy in the late 1980s and early 1990s have turned to what could be called 'the annihilation of space by law.' That is, they have turned to a legal remedy that seeks to cleanse the streets of those left behind by globalisation and other secular changes in the economy by simply erasing the spaces in which they must live" (Mitchell 1997: 304). Thus, while there has been a rolling-back of the welfare state, there has also been a rolling-out of the state via new forms of punitive regulation of the poor and the socially excluded (Wacquant 2000; Peck 2003).

\subsection{The Entrepreneurial City, Uneven Development, and Housing Provision}

Summarising the theoretical debate on the current historical regulatory processes at the urban level, four main features can be attributed to the entrepreneurial city (see Figure 2.1): The priority of growth oriented economic development policies; the withdrawal and re-commodification of welfare provision; the inclusion of private actors in policy formulation and implementation; and new forms of social control and punitive regulations. The entrepreneurial city debate also analyses the consequences of these characteristics, notably the different forms of social exclusion and the increasing socio-spatial inequality. These characteristics of the entrepreneurial city, especially economic development policies facilitated through public-privatepartnerships, as well as the outcome of increasing inequality, are well analysed. However, there is a missing link between the different features of the entrepreneurial city and what it is about them that create socio-spatial inequality. Both, regulation theory and the entrepreneurial city literature disregard the uneven causal mechanisms between regulatory and institutional changes and the outcome of socio-spatial inequality. Thus, the theoretical debate around the social mode of regulation and the entrepreneurial city has left us with questions about how do the withdrawal and recommodification from welfare provision lead to socio-spatial inequality? What are the causal processes behind the re-commodification of welfare provision that create uneven development at the urban level? 
Figure 2.1: The Entrepreneurial City

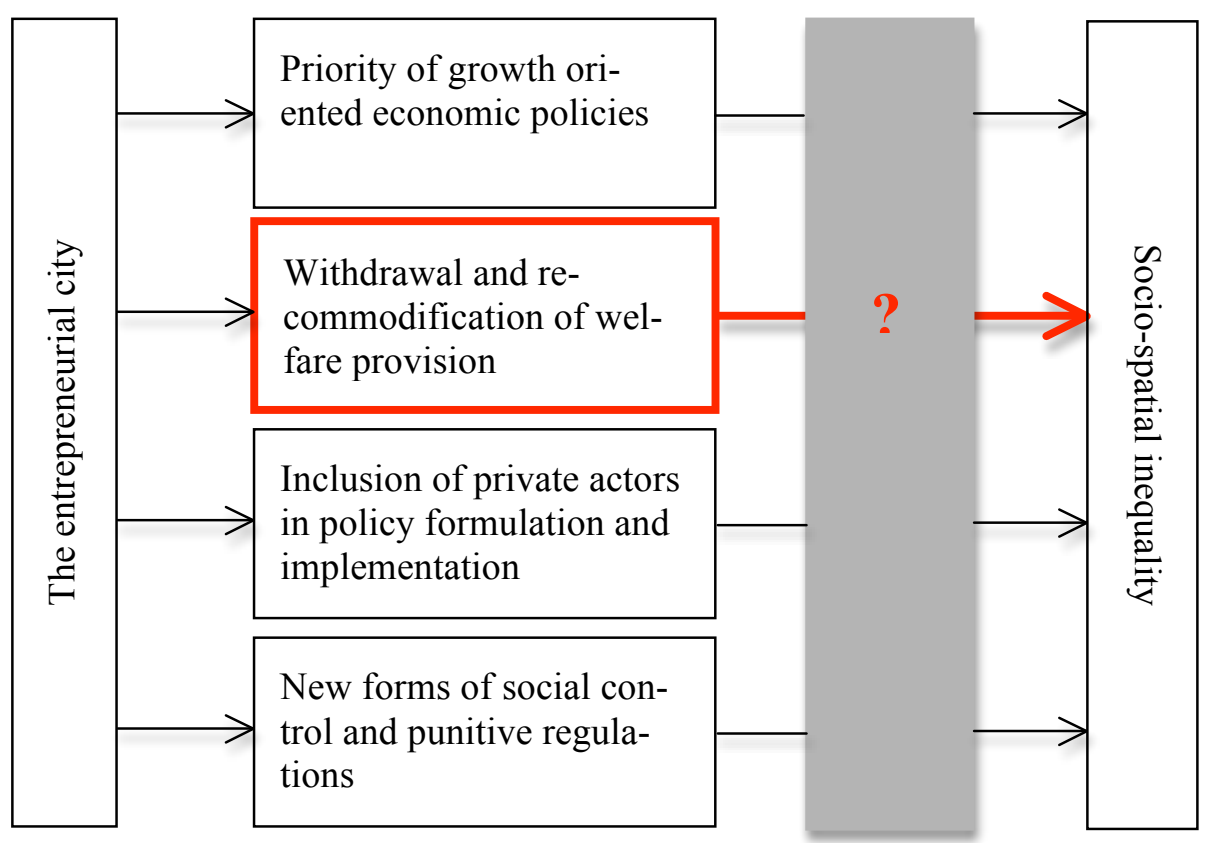

By disregarding the links between institutional change and socio-spatial outcome, the theory risks neglecting the multi-dimensionality of the entrepreneurial city processes and therefore the concept itself. Thus, the model is one-dimensional and does not account for different forms of urban entrepreneurialism or different strategy outcomes. The model of urban entrepreneurialism therefore underestimates the spatiotemporality and the various forms of urban entrepreneurialism that exist within a specific context (Sayer 2004). Within urban entrepreneurialism, there are multiple regulatory dimensions with intended and unintended consequences (Painter and Goodwin 1995). Depending on the institutional and spatial-temporal context, there might be constraints to the entrepreneurial strategy of the state. By disregarding these multiple dimensions, the intended and unintended consequences, the conceptualisation of the entrepreneurial city creates a black box whereas all the constraints and opportunities of the entrepreneurial strategies are hidden and remain unexplained (see Figure 2.1). The theory thus is not able to provide an adequate model for explaining concrete processes of uneven development.

Research therefore needs to avoid what Sayer (2004: 30) calls the "reduction of the concrete to the abstract or a fetishisation of certain transient and contingent social forms as the only possible results of capitalist development, with a consequent underestimation of the variety of forms that the latter can take". There is a "need to move beyond 'thick descriptions' of state restructuring, policy reforms and new forms of governance to ask what it is that the state is actually doing - why, where and with 
what political, social and economic implications" (Peck 2003: 222, original emphasis). Hence, there is a need to look at the spatial and temporal specifics, but also, and more importantly, at a particular domain of urban governance, such as the withdrawal and re-commodification of welfare provision, and more specifically the transformation towards a more entrepreneurial form of housing provision.

Scholars of the entrepreneurial city have rarely focused on particular policy domains to investigate the transformation process and its consequences. In the cases where they did investigate a specific area of urban governance, they focused on economic growth oriented strategies, such as large-scale redevelopment projects. Much less, if any at all, has been said on the withdrawal from welfare services, and more specifically on the transformation of housing provision. There is however a considerable amount of housing research (see, for example, Lundqvist 1992; Whitehead 1993; Harloe 1995; Aalbers and Holm 2008), which investigates the transformation of housing provision during the last decades. The three processes that characterise the entrepreneurial city - re-scaling, prioritisation of economic growth over social welfare, and institutional restructuring - are confirmed by housing researchers. The following section briefly summarises the main arguments confirming an entrepreneurial turn within the governance of housing provision.

\subsubsection{Housing Provision within the Entrepreneurial City}

Since the 1980s, state responsibilities in the domain of housing provision have continuously been shifted. On the one hand, there has been a shift of state competencies towards the European Union, even though they are not as significant for the provision of housing as for other policy domains. ${ }^{34}$ On the other hand, and this is more significant, there has been a devolution of competencies from the national level to the regional and local state levels. Thus, housing development is increasingly organised based on the principle of "local solutions to local problems" (Kleinman 1996: 8, original emphasis).

At the urban level, a more entrepreneurial form of housing provision manifests itself in two ways. First, the withdrawal from social welfare is confirmed through a shift from state-led provision of housing for the masses to a drastically reduced form of

\footnotetext{
${ }^{34}$ The European Union has no direct competence in the provision of housing. However, it influences the provision of housing through directives that exist in other domains such as banking or construction. Furthermore, through its regional policy and the structural funds, the European Union also, even though indirectly, subsidises the provision of housing. See Blöcker and Hieber (2003), Ghékiere (1992), and Rudolph-Cleff (1996) for a detailed analysis of the influence of the European Union on the provision of housing within its member states. For an analysis of the specific influence of the European Monetary Union on housing provision in Europe, see Priemus and Dieleman (1999).
} 
state intervention, which targets low income households (Harloe 1995). The government withdraws from the provision of social housing through changes in the finance system - from public loans to private loans - leading to a more competitive finance system. Moreover, the government privatises the social housing stock and promotes home ownership, reduces supply-side subsidies in favour of housing allowance, and deregulates rents (see, for example, Priemus and Dieleman 1999; Turner and Whitehead 2002; Aalbers and Holm 2008).

The second way urban entrepreneurialism manifests itself is closely connected to the first way. The privatisation of housing markets provides "the platform on which largescale multifaceted urban regeneration plans [...] are established" (Smith 2002: 438). In the 1960s, gentrification was a marginal phenomenon characterised through the movement of middle class households into low income areas. This was often accompanied by the exploitation of a rent gap (Smith 1996), whereas landlords bought derelict housing in low income areas cheaply, modernised it and rented it at inflated rates. This movement was however mostly independent from the public housing sector (Smith 2002). Since the end of the 1990s, governments have however increasingly started to promote "market-led gentrification as an instrument of both urban regeneration and social and economic policy" (Lees 2003: 572). Through partnerships between the local states in charge of planning and private capital, cities increasingly use gentrification as a means to improve their position in the interurban competition (Smith 2002).

While the housing literature provides the specificities, which are under-researched in the entrepreneurial city literature, it is most often concerned with explaining a particular form of housing provision. A gap, however, remains in understanding the causal relations between a particular form of housing provision - in this case a more entrepreneurial form - and the socio-spatial inequalities this creates. Thus, to iterate my argument: The entrepreneurial city debate is unable to explain the causal links between the transformation of urban governance and uneven development because it is prone to generalisation and neglects to look at the specific processes. In contrast, the housing literature is too focused on explaining a particular mode of housing provision or housing policy and does not go beyond the specificities of housing. Using a realist approach, this thesis aims to find a middle way in order to understand the causal relations between the transformation of urban governance and uneven development. While using the provision of housing as an example of a particular sector, the thesis aims foremost to contribute to the debate on regulation theory, the entrepreneurial city, and uneven development. 


\subsubsection{Processes of Uneven Development: A Realist Approach}

In order to understand uneven development within a specific place, research needs to address the causal mechanisms and necessary relations of regulatory processes (Sayer 2004). Moreover, research needs to investigate real processes, such as the specifics of housing provision. Only then, can the concept of uneven development move away from a mere reflection on different outcomes through different modes of social regulation in different places, territories or scales (Brenner 2009; Jessop et al. 2008). Uneven development is then no longer the mere outcome of regulatory differences, but is part of the process itself (see Pratt 1994). In order to move away from the mere confirmation of the transformation toward an entrepreneurial city and an uneven outcome, the thesis takes a realist approach (see chapter 3).

The realist approach emphasises the causal mechanisms between objects (transformation towards an entrepreneurial city) and events (processes of uneven development). Thus, through a method of abstraction between contingent and necessary relations of an object, "reasons which cause actors to act as they do" are identified (Sayer 2004: 41). The critical realist approach reflects a "greater appreciation of the multifaceted nature of the empirical world than do middle-range theory and grounded theory, which tend to restrict themselves to one or two of these levels or dimensions" (Layder 1993: 7). At the same time, the realist approach offers a "model of society, which includes macro (structural, institutional) phenomena as well as the more micro phenomena of interaction and behaviour" (Layder 1993: 7). This enables an understanding of how the behaviour of particular actors creates, under specific structural influences, processes of uneven development. It also allows a sensitive perception to the geographical and historical specificities involved in social processes.

The aim is to analyse the specific causal mechanisms of urban entrepreneurialism creating uneven processes. The thesis objects to a reconfirmation of general processes, which hide the causal relations of the transformation of urban governance and its uneven consequences. This requires investigating not only the specificities of time and place, but also the real processes of a particular sector: in this case housing. Looking at the reorganisation of Berlin's mode of housing provision, the focus lies on the entrepreneurial city's withdrawal from and re-commodification of the welfare provision. By explaining the mechanisms hidden in the black box (see Figure 2.1), the thesis eventually contributes to a re-conceptualisation of the entrepreneurial city by bringing out its multidimensionality. 


\section{Conclusion}

This chapter first drew on the concept of local modes of social regulation in order to understand the relation between the local state and uneven development. Local modes of social regulation are negotiated through the state, defined as a complex form of social relations guided through specific institutions. The state institutions are, however, always based on previously negotiated modes of social regulation. The historical institutional context is therefore essential to understand current regulatory processes. Local modes of social regulation are furthermore always integrated within wider regulatory processes at different scales and within different places. This leads to an uneven development between scales and places which then reproduces specific modes of social regulation. Thus, for an analysis of current processes of uneven development, understanding the historical spatial context is of great relevance.

In order to apply these abstract concepts within a specific historical and spatial context, the thesis calls on the middle-range concept of the entrepreneurial city. This is useful in order to understand the reorganisation of the local state within the specific context of economic globalisation. It describes the current local mode of regulation based on entrepreneurial state strategies of promoting economic development and withdrawing from the provision of welfare. This state strategy is achieved through institutional change giving greater emphasis on private agents in policy formulation and implementation and new forms of social control and punitive regulations. The consequences of entrepreneurial state strategies are various forms of social exclusion and socio-spatial inequality.

The approaches, on the more abstract level of regulation theory but also on the middle-range level of the entrepreneurial city debate, miss however the links between regulatory and institutional changes at the local state level and socio-spatial inequality. By disregarding these links, the theoretical model does not account for multidimensional processes of the entrepreneurial city. The thesis addresses these missing links by analysing the causal mechanisms of the reorganisation of a particular domain of the local state. By looking at the reorganisation of Berlin's mode of housing provision, the thesis analyses the causal mechanisms between the regulatory and institutional changes and its uneven consequences.

In order to analyse the causal mechanisms, the thesis turns towards a critical realist approach. Chapter 3 discusses the critical realist philosophy and its methodological approach. By identifying the key concepts of regulation, production, and consumption, and their relation within the provision of housing structure, chapter 3 outlines a model for analysing the particular mode of housing provision in Berlin and its causal mecha- 
nisms creating processes of uneven development. Chapter 3 further provides an account of the fieldwork and data collection process. 


\section{A Critical Realist Methodology}

Chapter 2 proposed a critical realist perspective in order to analyse the question of what is it about the entrepreneurial city and its withdrawal from social welfare, such as housing, that creates processes of uneven development. The aim of this chapter is to introduce critical realism and a method of iterative abstraction that links the theoretical conceptualisation with empirical research (3.1). The chapter provides a "hypothetical conceptual model" (Lawson et al. 2009: 4) to analyse the particular mode of housing provision in Berlin. It proposes to research the contingently emerging relations of regulation, production, and consumption within their spatial and temporal context (Lawson 2006) (3.2).

Having introduced the theoretical model for analysing the structure of housing provision, the second part of the chapter describes the practical aspects of the research project. This part is divided into three steps: First, it is argued why a case study approach has been chosen (3.3) - the theoretically guided case selection is outlined and each case is shortly described; second, the fieldwork process is presented (3.4) - the main data source was in the form of semi-structured interviews with key informants, which has been triangulated with an in-depth document analysis and the participation in symposia on housing in Berlin; and third, the method of analysis of the collected data is discussed (3.5).

\subsection{Critical Realism}

Critical realism is a version of realist philosophy proposed by Bhaskar (1979) for the social sciences. In rejection of the positivist view as well as the constructivist view, critical realists believe in a world that is independent from our knowledge of it. Thus, while the theory, meaning our knowledge of a certain phenomenon, is likely to change over time, the phenomenon itself does not necessarily change (Sayer 2000: $11)$.

Critical realists do not try to find regularities, because causality is not based on the number of times something happens. Rather, causality is understood as the necessary and possible conditions of a causal mechanism to create a certain event, such as the processes of uneven development. "The conventional impulse to prove causation by gathering data on regularities, repeated occurrences, is therefore misguided: at best these might suggest where to look for candidates of causal mechanisms" (Sayer 2000: 14). Thus, "identifying causal mechanisms and how they work, and discovering if they have been activated and under what conditions" creates explanations (Sayer 2000: 14). The same event can be produced through different causal mechanisms and the 
same causal mechanisms can produce different events. "[U]nintended consequences and unacknowledged conditions" influence these processes (Sayer 2000: 20).

In order to identify causal mechanisms, it is important to analyse the power of actors and/or institutions, referred to as objects. The power of objects depends on the relation to other objects, but also on the specific context. Thus, the power of a specific object (necessary relations) is only activated under particular circumstances (contingent relations). Necessary relations are therefore not fixed, but are "actualised in the context of" contingent relations (Lawson 2001: 35). As an example, the power of private investors to act according to their strategy depends on their relation to other institutions like creditors, but it also depends on the specific context of the regulatory framework of Berlin's housing provision. Thus, the behaviour of a private investor is not explained based on "formal similarities" like the size of the investment firm, but "by reference to the concrete conditions in which they were situated" (Sayer 2000: 24).

By emphasising the causal mechanisms, critical realism also resolves the tension between structure and agency (Giddens 1979, 1984). According to critical realism, structures are presupposed by actions that are themselves influenced by previously constructed structures. Thus, structures influence the event, but critical realism acknowledges that structures themselves are constructed through agents. The structures are therefore determined by the way they play out in practice through individual agency. "Social structures do not endure automatically, they only do so where people reproduce them; but, in turn, people do not reproduce them automatically and rarely intentionally" (Sayer 1992). ${ }^{35}$

In order to find the causal mechanisms of a certain event, critical realists move between concrete events and abstract models. While abstract theory analyses the power relations of certain objects, concrete research "looks at what happens" when the power relations of these objects are combined (Sayer 1992: 116). On the one hand, abstraction helps to theorise the characteristics and power of an object. On the other hand, abstraction helps to distinguish between contingent and necessary relations of objects and events. Thus, the process of abstraction isolates partial aspects of an object. In the case of the mode of housing provision, an example for an abstracted concept is the relation between finance and housing. The abstraction, however, is based on a real phenomenon (Yeung 1997). Thus, iterative abstraction is both inductive because it starts from a concrete observation, and deductive because the constructed

\footnotetext{
${ }^{35}$ See Pratt (1994) for a discussion on the differences between a critical realist approach to the structure-agency problem and Giddens' (1984) theory of structuration. See Jessop (2005) for a critical discussion on the structure-agency problem within critical realism.
} 
abstract model is again tested against the concrete phenomenon. It is an iterative process of conceptualisation and re-conceptualisation (Pratt 1995). The abstract model can be adjusted, so that no more contradictory evidence between the causal relations of the empirical analysis and the abstract model is found (Yeung 1997). The thesis therefore started from a concrete event: The uneven spatial development of Berlin's mode of housing provision. Guided by different concepts abstracted from the reorganisation of the mode of housing provision (object), the empirical research then explored the causal relations of these objects.

In a first step, the reorganisation of the particular mode of housing provision was abstracted through the isolation of different concepts influencing the mode of housing provision (see Sayer 1992: 87). It is, however, not possible to establish all the abstract concepts and their causal powers contributing to the mode of housing provision "at the outset of the research" (Sayer 2000: 20) because an established model would only be misguiding and prevent the scrutiny of the multidimensionality of the particular mode of housing provision. Thus, discovering the causal powers and analysing the way they operate are a "key component [...] of the research" (Sayer 2000: 20). A checklist of abstract concepts related to the mode of housing provision however helps as a starting point for the empirical research. In a second step, the aim of the empirical research is then to elaborate on these abstract concepts, feeding them with concrete power relations in the particular context of Berlin (see chapters 5-7). Only then, can we explain how the particular mode of housing provision in Berlin contributes to uneven development. The next section outlines the abstracted concepts.

\subsection{Causal Mechanisms of Housing Provision}

As outlined in chapter 1 and 2, the aim of the thesis is to analyse the specific causal mechanisms leading to uneven spatial development of an 'entrepreneurialisation' of Berlin's mode of housing provision, meaning the state's withdrawal from, and recommodification of, housing provision. The thesis' objective is however to go beyond the confirmation of whether Berlin's government has withdrawn from and recommodified the mode of housing provision. Moreover, the goal is to analyse the consequences of urban entrepreneurialism of Berlin's housing provision by revealing the uneven causal mechanisms generating temporary forms of social and spatial inequalities. In order to analyse the state's re-regulation of housing and its causal mechanisms leading to uneven development, a critical realist approach was argued for. In housing research, this approach has been furthest developed by Lawson (2001, 2006) who adopted Ball's (1983, 1986; Ball and Harloe 1992) meta-theoretical tool of the structure of housing provision (SHP). 
Contrary to what Ball calls the consumption-oriented approaches, which focus on isolated issues like, for example, the changing nature of housing subsidies (see Ball 1986; Ball et al. 1988), Ball's concept of the structure of housing provision takes into account all of the relevant agencies in the structure of provision and their effects on each other (Ball 1986: 152). This approach has however been criticised for missing a generalisation of social relations within housing systems, which is going beyond economic relations. Moreover, it misses a clear distinction between the necessary power of certain relations and their contingent contextual factors influencing these relations (Lawson 2006: 27; see also Lawson 2001: 34). ${ }^{36}$

Lawson $(2001,2006)$ therefore developed Ball's SHP through an "explicit application of critical realist ontology and notions of causality, comparing contingently defined emergent relations underlying different modes of housing provision through comparative historical analysis" (Lawson et al. 2009: 6, original emphasis). In order to analyse causal mechanisms of the changes of a particular housing provision and their consequences, it is therefore more valuable to single out key internal (necessary) and external (contingent) relations of housing provision (Lawson 2006: 64). Internal relations are defined through the interdependence of the concept to its object. For example, the housing developer cannot exist outside of the mode of housing provision. The relationship between the two is therefore necessary. External relations, in contrary, are not dependent on each other and are therefore contingent in the way they affect the particular mode of housing provision (see Sayer 1992: 89). Thus, external relations are contextually determined factors influencing the particular mode of housing provision. Defining a cluster of the three necessary relations of property rights, investment and savings, and labour and welfare, Lawson (2006) proposes a more general model to investigate the particular provision of housing structure.

These necessary relations bind the different agents within the provision of housing structure, such as the relation between tenant and landlord, or borrowers and lenders (Lawson 2001: 35). The way these relations play out in practice depends on contingent relations. The necessary relations help however to explore the "realm of the possible" (Lawson 2001: 37) for the agents. Lawson (2001: 37) builds upon the concepts of risk and trust, arguing that agents in the structure of housing provision adapt their strategies based on the risks posed by the contingent relations. This means agents change their strategies based on the specific spatial and temporal context.

\footnotetext{
${ }^{36}$ See also the more general debate on systems of provision (Fine and Leopold 1993) which overcomes the dualistic opposition of consumption versus production by analysing systems of provision of particular commodities, such as food or clothes.
} 
Aiming to explain the outcome of different types of housing provisions in a comparative study, Lawson (2006: 85) defines the state as a contingent relation to the provision of housing. The state plays a "mediating, sometimes conflicting role establishing" a coherent cluster of housing provision. Coherence occurs when property rights, investment and saving, and labour and welfare are "able to sustain a particular form of housing provision" (Lawson 2010: 209). Periods of coherence are followed by periods of crisis when "one or more components of the emergent cluster evolve in such a way as to destabilise" the other components, which leads to adaptation (Lawson 2006: 87). Through a historical analysis of the contingently defined emergent relations of property, investment and savings, and labour and welfare during periods of crisis and periods of coherence, Lawson $(2001,2006)$ explains the temporal outcome of particular types of housing provision, such as private rental housing or occupied-ownership housing.

In contrast to Lawson $(2001,2006)$, the goal of this thesis is to explain particular processes of uneven development that are triggered through a particular mode of social regulation. The thesis thus aims to find empirically grounded explanations for how housing provision works within a more entrepreneurial state strategy, creating processes of uneven development. While remaining within Lawson's $(2001,2006)$ approach, the conceptual model adapted for the purpose of this study, gives the state a more dominant role. Ball (1986: 161) argues for an inclusion of the state "where state agencies are necessary parts of structures of provision". In accordance with Ball (1986: 161), the state's mediating role is considered as a necessary relation of the structure of housing provision. The necessary relations of the structure of housing provision are therefore defined as housing regulation, housing production, and housing consumption. These relations emerge under the contingent relations of space and time (see Figure 3.1). In the following, the necessary and contingent relations are developed and possible routes for the following empirical analysis explaining how the state's reorganisation of the housing provision influences housing regulation, production, and consumption are explored in order to understand the causal mechanisms of processes of uneven development. 
Figure 3.1: Structure of Causal Explanation for Processes of Uneven Development

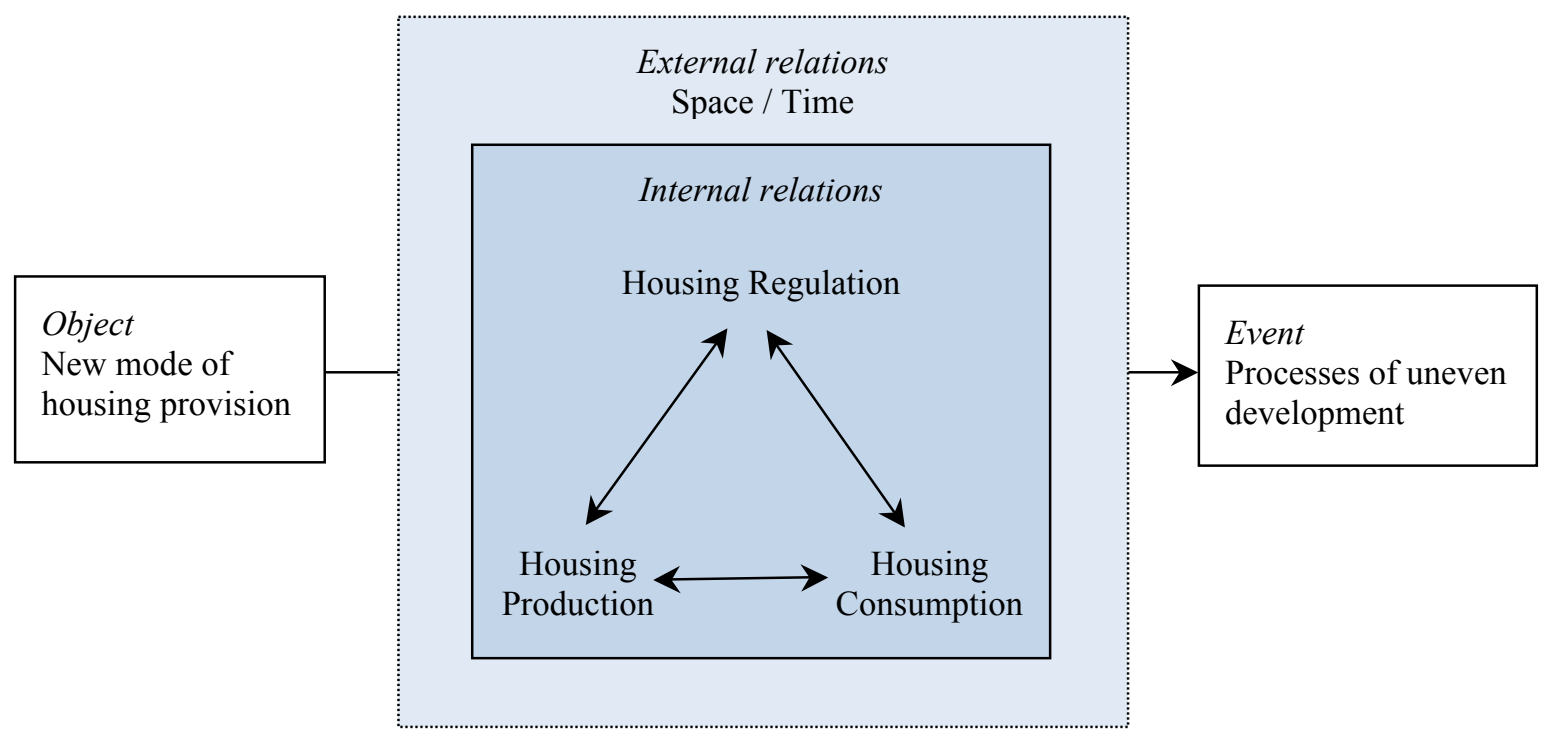

Source: Inspired by Sayer (1992: 109) and Lawson (2006: 165)

\subsubsection{Necessary Causal Relations}

Housing regulation, production, and consumption are considered as the necessary relations of the provision of housing structure. These relations are however not fixed; they change depending on specific combinations with other necessary relations under specific contingent conditions (see section 3.3.2) (Lawson 2006: 78).

\section{Housing Regulation}

The national, but also the local state intervenes in production and consumption for various reasons, from facilitating access to the housing market for low income households to promoting economic growth through the support of housing construction and therefore consumption (Lawson 2006: 74). The state mediates the consumption and production relations through regulatory conditions, which are referred to here as housing regulation. Housing regulation is perceived as constraining or enabling rights to develop, maintain, exchange, and use rental housing. Housing regulation includes property rights and subsidies.

Property relations are defined as the rights of occupation, ownership, and exploitation of land and buildings. This in turn, affects the value of the land and the housing on it. In the case of rental housing, the value of a building depends at least partially on the building's "capacity to generate rental revenue" (Lawson 2006: 68). Restrictions on private property rights such as rent or planning regulation therefore affect production 
and consumption relations. Rent regulation can have constraining effects on the generation of rental revenue. Three rental systems can be distinguished based on rent control. First, there is no rent control and landlords can charge according to market criteria. Second, landlords are restricted by rent control in the amount they can charge or increase the rent levels. Third, landlords are forced "to collectivise any inflation in the market value of housing, in essence feeding back profit to tenants in the form of lower rents" (Doling 1999: 160). Linked to rent regulations are the protection against tenants' eviction in cases where the tenant cannot pay the rent or where landlords have other interests to vacate the dwelling. Rent regulations determine the possibilities of making profit through rental revenue, therefore influencing the finance of and investment in housing. Planning regulations from zoning regulations to building regulations such as the specific rights to modernise housing under heritage protection can also affect the rental revenue. Property rights therefore influence the investment strategy and the form of surplus value extraction; they "[i]nfluence the nature of use, exchange, exploitation of land and subsequently, patterns of investment in land development over space and time" (Lawson 2006: 78).

Through housing subsidies, the state can promote the production and consumption of housing. There are supply-side subsidies such as public or private loans or interest subsidies for the construction and renewal of housing, or demand-side subsidies such as housing allowances. The intervention through supply-side subsidies towards housing infrastructure can lower construction costs and rent levels (Turner and Whitehead 2002). In order to support poorer households, the state grants demand-side subsidies (Doling 1999; Priemus and Dieleman 1999) (see below). Changes in these subsidy systems can impact rent levels and investment in housing.

\section{Housing Production}

Housing production is defined as the relations involving the production and exchange of rental housing. It involves finance in the form of equity or credit capital combined with profit targets. Finance in turn influences the investment, management and exchange strategies of housing owners. In the structure of rental housing provision, production relations emerge through different types of housing owners that adapt their strategies based on the other necessary relations of housing regulation (see above) and housing consumption (see below) under the contingent spatial and temporal contexts (see section 3.2.2).

The development and exchange of housing depends, to a great extent, on the availability of finance due to the high costs of housing. The purchase of housing requires significant credit capital. This can come in different forms such as loans or equity 
share holding (Lawson 2006: 73). For loans, interest levels might be fixed or flexible and are predetermined for a specific time period. The conditions of interest levels depend on the form of tenancy, but also on market mechanisms that affect the entire financial system (Lawson 2006: 75). For equity shareholding, different investors have diverging expectations regarding risk and return on investment. While some investors look for relatively long-term and risk-averse investments, albeit with low returns, others pursue more short-term, high risk, and high return strategies.

Real estate investment involves balancing risk and return with a lot of uncertain factors that are sometimes difficult to value: There are opportunities in the form of increasing cash flow, financial management, and exit strategies. First, cash flow can be increased through higher rental income or reduction of expenditure. Depending on rent regulations, higher rents can be achieved through new tenancy agreements or by refurbishing the housing stock. Reducing operation costs by creating economies of scale or streamlining management also helps to generate cash flow. Second, investment opportunities also exist through leveraging via debt financing. ${ }^{37}$ Third, different exit strategies exist, such as re-selling the housing for a higher price or going public (Linneman 2004).

Real estate investment however also involves the following risks: First, there could be unforeseen operation costs such as higher property taxes, insurance costs or management salaries. Some of the costs can be reduced through longer-term contracts or passed onto tenants. However, depending on rent regulation or a depressed market situation, the costs cannot be passed on. Second, vacancy rates reducing cash flow from rent poses a considerable risk. This depends again on tenancy agreements and how fast a new tenant can be found when the existing one decides to leave. A third risk is that a house is much harder to sell than other assets such as government bonds or stock options. This could lead to liquidity problems due to real estate market fluctuations whereby the seller cannot unload the asset at the anticipated asking price (Linneman 2004).

Depending on the strategy, investors "rely on a financial return via the developments in rental revenue, improved land value or the sale of related mortgages" (Lawson 2006: 74). These factors influence the housing provision in that the investor "may demand particular forms of marketable development, building processes and standards, or the minimum rent level and even specify the desired profile of eligible tenants" (Lawson 2006: 73). This in turn affects the ownership structure and consumption of housing (Ball 1986: 156, 160). Certain types of capitalist enterprises therefore profit

\footnotetext{
${ }^{37}$ See section 5 for an explanation of how financial leveraging works for real estate investment.
} 
from housing provision in "particular historical circumstances" (Ball 1983; see also 1990).

\section{Housing Consumption}

Housing consumption emerges through aggregated demand, defined here as income relations and household structure. Consumption is determined by the tenant's capacity to pay for housing costs. In a rental housing market, the "ebb and flow of effective demand and supply" (Lawson 2006: 70) influence rent levels. If mortgages, for example, become more expensive due to high interest rates, there will be more demand for rental housing, therefore increasing rent levels. 'In an 'open' rental market, rents are set by the imperfect operation of the rental market, where tenants compete for dwellings of different types, quality and location" (Lawson 2006: 70). However, rent levels are also influenced by rent regulation, and state intervention through supply or demand side subsidies.

The tenant's capacity to pay for housing costs depends however not only on the rent level, but also on the tenant's position in the housing market. A tenant in a stressed housing market is in a less powerful position to negotiate lower rent levels than a tenant in a depressed housing market. The capacity to pay for housing costs depend also on the tenant's position within the labour market (Lawson 2006: 75 et seq.). An unemployed tenant does not have the same budget as a high-earning employee for housing consumption. Moreover, housing consumption also depends on the household structure. A single household needs comparatively more housing than a large family. Thus, the tenant's economic, but also demographic and household specifics, influence the form of housing consumption (Ball 1986: 154).

While income relations and household structure play a role in the provision of housing structure, I argue here that consumption of housing is mainly explained through production relations, but also mediated through the state (Lawson 2010: 209). Housing cannot be replaced with another good. This possibly constrains the consumer's position in negotiating prices (Krätke and Borst 2000: 159). Smith (1996: 57) even argues that the "need to earn profit" is more important than consumption preferences. Thus, the expressed demand by different consumers have a minimal role to play in the uneven market mechanisms, which are best explained via the particular mode of housing production and regulation. 


\subsubsection{Contingent Causal Relations}

Critical realists have very little to say about space and time in the abstract. However, "abstract research, being concerned with the character, powers, and preconditions of social structures, has to take account of the fact that they are neither aspatial nor ' $a-$ chronic" (Sayer 2000: 136). Thus, the particular time and space makes a difference to the social relations of the provision of housing structure. In order to understand how time and space influences the provision of housing structure, there is however a need to "move to a more concrete kind of analysis", in which we investigate the necessary relations proposed above within "concrete spatial conjunctures" (Sayer 2000: 112).

\section{Spatial context}

Theory cannot anticipate the influence space has on the necessary relations of the mode of housing provision. However, "by building into the theory an assumption about the form of the particular (contingent) spatial setting that happens to exist" (Sayer 2000: 122), the particular spatial setting influencing internal relations can be worked out. With regards to the provision of housing structure this means, for example, "a housing market does not clear at a point in time over a whole area but evolves sequentially and is constrained by wherever and whenever vacancies and potential buyers crop up" (Sayer 2000: 123). Moreover, housing is highly interwoven with "its location in social and physical space" (Ball 1986: 162), but also with its morphology in terms of design and production quality. Due to the heterogeneity and inflexibility of housing, there are different market segments. On the one hand, the immobility of the good means that there are spatially differentiated market segments. On the other hand, there are factually differentiated market segments based on such characteristics as quality, age, and size of housing. ${ }^{38}$ The housing owner's strategy is therefore closely linked to a specific market segment. At the same time, a segmented housing market influences the consumption. There is no equal access of tenants to all the housing units: Based on location, economic and social criteria, different groups of tenants have access to different market segments.

\footnotetext{
${ }^{38}$ See Krätke and Borst (2000) for a discussion of the concept of 'segmented housing market' and its impact on social segregation.
} 


\section{Temporal context}

Time is as important as space in influencing a particular mode of housing provision. Specific events such as general financial and economic crises influence the housing provision by inducing "shifts in the operation of specific financial institutions and in their regulation" (Ball 1990: 36). The restructuring of the financial system and the globalisation of capital can influence the investment process in housing. Similar to an economic crisis, political and social events such as state transformation processes influence the mode of housing provision.

This conceptual model guides my empirical research, investigating how the necessary relations play out in the particular spatial and temporal conditions of Berlin's provision of housing structure.

The next section presents the practical process in terms of case selection, fieldwork and data analysis. It serves three purposes. First, the section presents the reasoning for a case study approach and the theoretically guided case selection (3.3). Second, it discusses the fieldwork and data collection process including some of the challenges encountered (3.4). Third, the section presents the methodological approach for data analysis (3.5).

\subsection{Case Study Approach}

Critical realist work is predominantly conducted as intensive research because it is a useful mean to analyse "what makes things happen in specific cases" (Sayer 2000: 20). This means individual cases are studied in their specific contexts in order to detect the substantial causality between necessary and contingent relations of a phenomenon. The case study approach is particularly useful when analysing "complex social phenomena" (Yin 1994: 3). The empirical research therefore focuses on case studies.

A case study is defined as the process of analysing a specific case and the reporting of the inquiry (Stake 2008: 121). A case, in turn, can be described as a system with clear boundaries whereas certain activities take place within the case, and others outside of it. In this thesis, the case study approach was used in the sense of what Stake (2008: 123) calls a "multiple case study". The aim of the research lied not in understanding one particular case, but several: Multiple cases were studied in order to understand a specific phenomenon, in this context, the consequences of the reorganisation of Berlin's mode of housing provision. As such, I did not compare the four neighbourhoods 
selected for the study, but used them as a point of entry to understand Berlin's provision of housing structure as a whole.

\subsubsection{Case Selection}

The theoretically guided case selection is based on the assumption that a detailed understanding of these individual cases creates a better understanding of the general phenomena studied (Stake 2008). Thus, I selected the cases according to a purposive, meaning theoretical sampling based on categories defined by the causal mechanisms of my conceptual framework (see Pratt 1994: 69). ${ }^{39}$ The aim of purposive sampling was to cover the necessary and contingent relations relevant to the study. The sampling was diverse which enabled the exploration of the impact of specific contexts. By selecting cases that vary from each other, it was possible to analyse the central themes that cut across all of them (Ritchie and Lewis 2003: 78). The cases were chosen to expand on theoretical concepts. ${ }^{40}$

The case selection was guided by the theoretical concepts on the provision of housing structure established in section 3.2. The aim was to have a wide variety of cases involving the key relations and the contextual factors of the established model for analysing a particular mode of housing provision. Therefore, the selected neighbourhoods ${ }^{41}$ covered a variety with regards to regulation, production, consumption, as well as to their spatial context. ${ }^{42}$

- Spatial context: The selection of neighbourhoods with regards to the spatial context is based on the main housing types (see chapter 4); late $19^{\text {th }}$-century block developments; Nineteen Twenties, Thirties, Fifties row developments; and post-war high-rise developments.

\footnotetext{
${ }^{39}$ This realist interpretation of the case study approach differs slightly from a grounded theory approach (Glaser and Strauss 2009) in that it avoids the pitfalls of emergent categories, which are solely deduced from empirical research. Thus, the realist interpretation evades a categorisation, which possibly "reduces any structural factors to those of individuals" and which are "derived from "the analyst's head" instead of being "informed by the abstract theoretical analysis of causal mechanisms" (Pratt 1994: 69).

${ }^{40}$ See Glaser and Strauss (2009) for a detailed discussion on how theoretical sampling is used to develop and extend theory.

${ }^{41}$ The neighbourhood is defined based on the historical development of the housing structure (see chapter 4) in this neighbourhood. This means that a certain type of housing has been built in this neighbourhood and a specific name designates the area. For example, a housing development from the 1920s was called "Grüne Stadt" (Green City) and the blocks that are built within this housing development define the neighbourhood.

${ }^{42}$ The temporal context is given by the period studied, from 1998 to 2008 .
} 
- Regulation: The selection of neighbourhoods is based on different regulatory means: free-market housing, social housing, neighbourhood management, urban renewal area, milieu protection area, and restructuring ordinance.

- Production: The way the neighbourhood was financed, through credit capital or equity share holding was not identifiable beforehand. However, it was expected that privatised housing companies have different approaches to financing housing provision and therefore to investment, management, and exchange of housing.

- Consumption: Since it is rarely possible to get exact data on the tenant structure of specific neighbourhoods, the selection is based on the quality of the residential area, assuming that higher quality residential areas are more expensive and therefore attract tenants with a high socio-economic status; and lower quality housing provides for the poorer households. ${ }^{43}$

Table 3.1 presents the case selection. Based on these criteria, the cases were selected through an analysis of the media coverage that took place during the years of reorganisation of Berlin's housing provision and four preliminary interviews with housing experts in Berlin (see appendix 1).

\footnotetext{
${ }^{43}$ Berlin's government defines three types of quality of residential areas: good, middle and basic. The housing currently or previously owned by state-owned housing companies have primarily housing within the middle and simple residential areas. Since the focus of research lies on these two types of ownership, only these two categories are represented in my case selection.
} 
Table 3.1: Cases and Selection Criteria

\begin{tabular}{|l|l|l|l|l|}
\hline $\begin{array}{l}\text { CASE } \\
\text { Neighbourhood } \\
\text { (Main Street) }\end{array}$ & $\begin{array}{l}\text { SPATIAL } \\
\text { CONTEXT } \\
\text { Housing type }\end{array}$ & $\begin{array}{l}\text { REGULATION } \\
\text { Regulatory means }\end{array}$ & $\begin{array}{l}\text { PRODUCTION } \\
\text { Majority owner }\end{array}$ & $\begin{array}{l}\text { CONSUMPTION } \\
\text { Quality of residen- } \\
\text { tial area }\end{array}$ \\
\hline $\begin{array}{l}\text { (A) Grüne Stadt } \\
\text { (Anton-Saefkow- } \\
\text { Str.) }\end{array}$ & $\begin{array}{l}\text { 1930s row devel- } \\
\text { opment }\end{array}$ & $\begin{array}{l}\text { Free-market hous- } \\
\text { ing, restructuring } \\
\text { ordinance, heritage } \\
\text { protection }\end{array}$ & $\begin{array}{l}\text { Privatised housing } \\
\text { company owned by } \\
\text { institutional inves- } \\
\text { tors }\end{array}$ & Basic \\
\hline $\begin{array}{l}\text { (B) Chamissoplatz } \\
\text { (Arndtstr.) }\end{array}$ & $\begin{array}{l}19^{\text {th }} \text {-century block } \\
\text { development }\end{array}$ & $\begin{array}{l}\text { Former urban } \\
\text { renewal housing, } \\
\text { now milieu protec- } \\
\text { tion area }\end{array}$ & $\begin{array}{l}\text { State-owned hous- } \\
\text { ing company }\end{array}$ & Middle \\
\hline $\begin{array}{l}\text { (C) High-Deck- } \\
\text { Siedlung (Leo- } \\
\text { Slezak-Str.) }\end{array}$ & $\begin{array}{l}1980 \text { s row devel- } \\
\text { opment }\end{array}$ & $\begin{array}{l}\text { Social housing, } \\
\text { neighbourhood } \\
\text { management }\end{array}$ & $\begin{array}{l}\text { Privatised housing } \\
\text { estate owned by } \\
\text { institutional inves- } \\
\text { tors }\end{array}$ & Basic \\
\hline $\begin{array}{l}\text { (D) Gropiusstadt } \\
\text { (Liepschitz-Allee, } \\
\text { Wutzkyallee) }\end{array}$ & $\begin{array}{l}\text { Post-war high-rise } \\
\text { development }\end{array}$ & $\begin{array}{l}\text { Partly social hous- } \\
\text { ing, partly free- } \\
\text { market housing, } \\
\text { neighbourhood } \\
\text { management }\end{array}$ & $\begin{array}{l}\text { State-owned hous- } \\
\text { ing company }\end{array}$ & Basic \\
\hline
\end{tabular}

\subsubsection{Four Cases}

As mentioned, I used cases as an entry point to understand Berlin's provision of housing structure and not in order to compare them. The aim was to understand how production, regulation, and consumption play out spatially, meaning in different types of housing. As such, the neighbourhood's characteristics along the above discussed criteria were important and not the cases themselves. In the following, the four cases are therefore only shortly described with regards to their characteristics listed in Table 3.1. See Map 3.1 for an overview of where the neighbourhoods are situated within Berlin. For more details on the different housing types within the housing provision in Berlin, see chapter 4.

\footnotetext{
${ }^{44}$ Because each housing unit is individually evaluated, the residential area was based on the majority type within the neighbourhood. One - or where necessary - two of the main streets within the neighbourhood have been taken as point of reference. The data is based on the comparative rent index (Mietspiegel) of 2007. See Senatsverwaltung für Stadtentwicklung (2007b, 2009).
} 


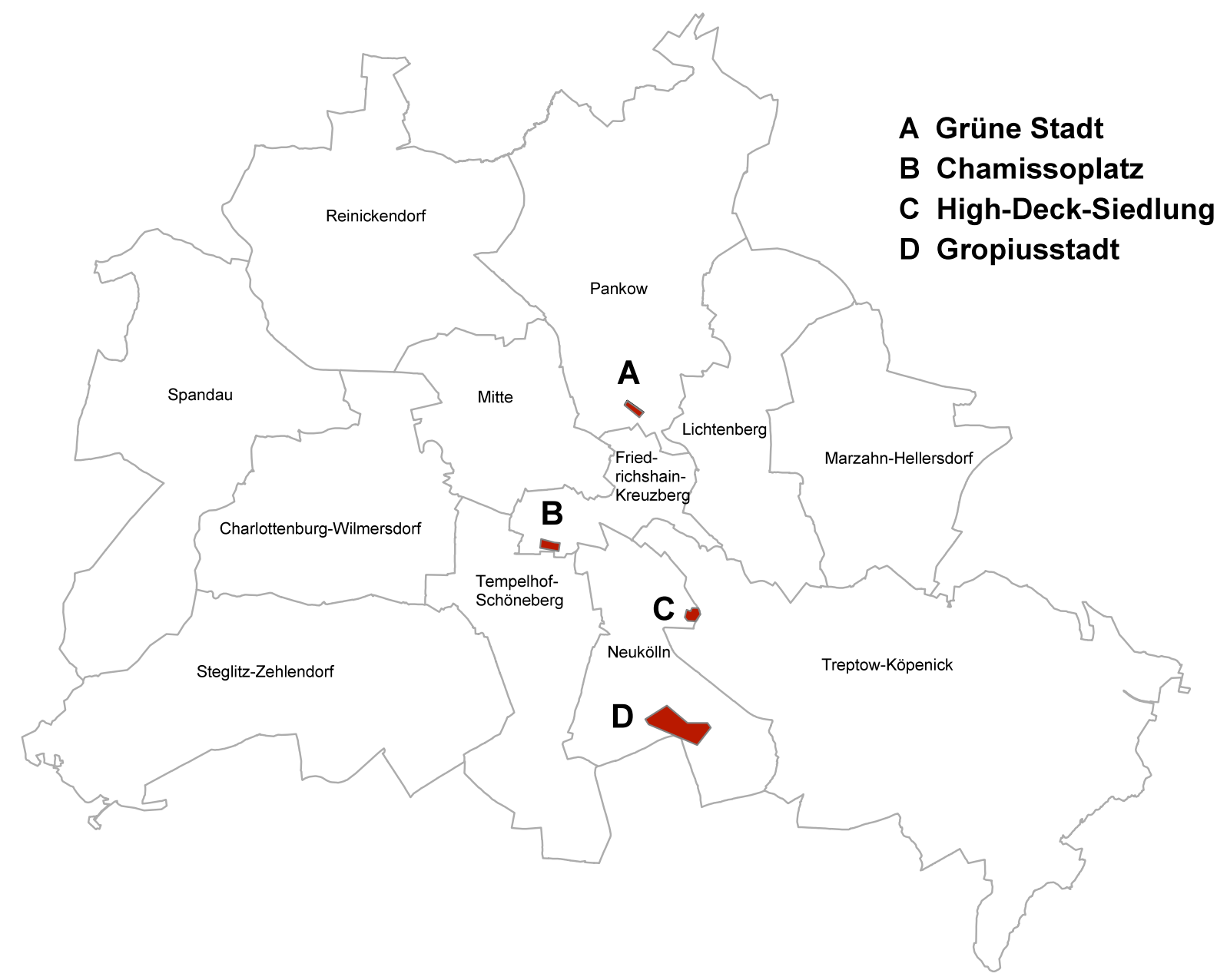

Grüne Stadt, Pankow (A)

The Grüne Stadt is located in Prenzlauer Berg, in the district of Pankow. This centrally located area was the "biggest urban renewal site in Europe" (Holm 2006: 12, author's translation) that has become highly gentrified after Berlin's reunification. The Grüne Stadt was built in the modern style between 1937 and 1939 (GSW 2007). Parts of the row development are under heritage protection. The Grüne Stadt has around 1,800 apartments, most of which had still been in the original state until they were renovated in 2005. The tenant structure was characterised by a high degree of low income households either because they are pensioners, unemployed, or on social welfare. Only 36 percent of the households were gainfully employed.

The Grüne Stadt apartments belonged to a state-owned housing company which prior to 2004, was the largest state-owned housing company. In 2004, Berlin's government privatised the company, and an investment consortium of two investment banks bought it. Thus, the apartments were no longer in the purview of state-ownership. In 
2005, the privatised company sold one part of Grüne Stadt to a smaller investment fund. When modernisation started that same year, the district imposed a restructuring ordinance that obligated the owners to draw up a social plan for the tenants who could not bear the higher rents. Because of an administrative delay, only the part owned by the smaller investment fund was under this restructuring ordinance. The part owned by the privatised company is now available through private ownership. The other part, owned by the smaller investment fund, is still rental housing.

\section{Chamissoplatz, Friedrichshain-Kreuzberg (B)}

Chamissoplatz is situated in the district of Friedrichshain-Kreuzberg. Kreuzberg is famous for its politically left-wing oriented population during the division of the city, welcoming young men who did not want to serve in the West German army. ${ }^{45}$ The Chamissoplatz neighbourhood consists of late $19^{\text {th }}$-century block developments built between 1889 and 1911 which were not destroyed during the Second World War. There are 1,600 apartments in the neighbourhood of Chamissoplatz, often with stores located on the ground floor of the blocks. The apartments were mostly renovated between 1978 and 2003. The quality of the housing and the location contribute to the relatively high standard of living in this area. This is reflected in the government's "middle" category of quality measurement (see above).

The apartments at Chamissoplatz are foremost in the ownership of a state-owned housing company. In the 1970s, the state mandated the state-owned housing company to buy the housing stock because private landlords were not able to pay renovation costs. The neighbourhood thus became a designated urban renewal area whereas its modernisation was highly state subsidised. Since 2003, the neighbourhood is no longer a designated urban renewal area, the district government however decided to confer the neighbourhood the status of a milieu protection area. This means that there are some restrictions on further renovations in order to keep a similar social structure within the neighbourhood (Bremer et al. 2007). The housing remains state-owned.

\section{High-Deck-Siedlung, Neukölln (C)}

The High-Deck-Siedlung is a row development neighbourhood at the fringe of the inner city area, in the district of Neukölln. The estate was built as social housing on the West side, close to the Berlin Wall, between 1975 and 1985. It has around 2,300 apartments. The division of car traffic and pedestrian sidewalks, the so-called highdecks, was considered an innovative housing model at the time. The status of social

\footnotetext{
${ }^{45}$ West Berlin's residents did not have to do military service.
} 
housing meant restrictions on allocation, and households whose income reached a certain ceiling had to pay additional fees on the rent. Today, the estate is considered as one of the most problematic neighbourhoods in Berlin. In 2007, around 600 apartments were vacant. The neighbourhood is under the neighbourhood management programme which adresses the social problems within the neighbourhood.

A state-owned housing company built the High-Deck-Siedlung. In 2006, the stateowned housing company sold the estate to an investment firm. The sales contract obliged the new investor to modernise the estate, which happened between 2007 and 2009. The state-owned housing company owns a remaining 427 apartments within the same estate. However, these apartments were only built between 1983 and 1993 and are therefore in better condition (Simons 2007). A few apartments also belong to a housing co-operative.

\section{Gropiusstadt, Neukölln (D)}

The Gropiusstadt is a large-scale housing estate with post-war high-rise developments in the district of Neukölln, in the outskirts of Berlin. Named after its planner, the architect Walter Gropius, the housing estate was built between 1962 and 1975 . However, the final housing estate has little in common with Gropius' original plan. One of the reasons was the construction of the Wall, which meant less available space to remedy the housing shortage. The need for densification resulted in high-rise developments that were higher than originally planned by Gropius. There are 18,500 apartments in the Gropiusstadt, 90 percent of which were constructed as social housing, mostly by two state-owned housing companies. The status as social housing meant that most apartments were under allocation restrictions as long as they were supported by state subsidies. However, in 2001, the restriction was released. Pensioners, often the ones who moved in during the 1960s and 1970s and an increasing amount of immigrants inhabit Gropiusstadt. Gradually, the different high-rise developments are coming onto the free market and are getting modernised (Kolland 2002). Part of the housing estate is under the neighbourhood management programme that is trying to address the rising social problems within the estate.

While one of the two initial housing companies is still state-owned and remains the owner of the majority of the apartments in the Gropiusstadt (approximately 6,000 dwellings), there are an increasing number of other owners. The other state-owned housing company has been privatised and is now part of a German housing company owned by institution investors. This privatised company has sold most of its apartments in the Gropiusstadt, either to individual homeowners or to smaller investors. It maintains approximately 2,000 dwellings in the housing estate. The owner that pos- 
sesses the third largest amount of apartments (approximately 1,500) in the Gropiusstadt is a social housing company (see chapter 7) owned by the protestant church.

\subsection{Fieldwork Process}

The data collection process was predominantly based on semi-structured interviews (Gaskell 2000; Kvale 1996; Wengraf 2001). There were three reasons for using this approach. First, a qualitative approach was prioritised in order to understand the underlying causal mechanisms of the reorganisation of Berlin's housing provision. Second, semi-structured interviews were used for exploring different views on a single empirical event. In contrast to more quantitative oriented surveys, the main object was to receive a wide range of viewpoints in order to understand the processes under scrutiny. Third, semi-structured interviews were based on an interview guideline along the theoretical concepts established above, but leaves enough space for exploring unanticipated relations (Gaskell 2000). Thus, the conversation remained open to information that the previously established theoretical model might not have taken into account.

The information collected through the semi-structured interviews was then complemented by a method of data triangulation ${ }^{46}$ whereas other data sources are used to get a more complete picture of the processes studied (Blaikie 1991; Denzin 1970; Seale 1999). Multiple data sources are compared and contrasted for the analysis of the same processes (Yeung 1997). This increases the validity and reliability of the data collected and helps to understand the phenomenon studied. The fieldwork also involved in-depth document analysis and the participation in conferences on the provision of housing in Berlin. The different data sources and the challenges involved collecting and analysing them are discussed in the following sections.

\subsubsection{Semi-structured Interviews}

Semi-structured interviews are trying to create knowledge through conversations between the interviewer and interviewee (Kvale 1996: 124). However, in order to extract evidence from these interviews, a theory-based guideline and contextual knowledge is necessary. Thus, the interviews are not just conversations on any topic (Wengraf 2001), but are based on the previously established theoretical model. There-

\footnotetext{
${ }^{46}$ For a critical discussion on the concept and various definitions of triangulation, see Blaikie (1991). Here, the term is used to describe the different data sources that were combined within a critical realist methodology.
} 
fore, the interview process involves different steps; from the preparation of an interview guideline to the interview situation itself.

\section{Constructing the interview guideline}

The interview guideline (Patton 2002: 343) was based on an elaborate case study protocol that I developed before fieldwork. This involved the establishment of expected relations guided by the theoretical framework. Once key causal relations had been identified, a detailed list of questions was worked out. These were then summarised and transformed into a language that was accessible for interviewees who might not be familiar with the theoretical language. The questions formed the basic structure of the interview guideline. However, the general guideline was kept flexible and was constantly adapted. Depending on the role of the respondent and the information gained from previously conducted interviews, the focus and therefore the guideline were slightly reformulated before each interview. For the general interview guideline, see appendix 2.

\section{Selecting actors and informants ${ }^{47}$}

In order to analyse the reorganisation of Berlin's housing provision, key actors were first identified (Wengraf 2001) informed by the causal relations of the conceptual model. On the one hand, this involved the identification of actors involved in the regulation of housing. These ranged from government bodies to non-governmental agencies that were involved in lobbying for tenants or housing companies. In accordance with a strategic-relational approach (Jessop 1990b, 2007), it is argued that all these actors use the state to promote their interests. Thus, they play a crucial role in the regulation of the provision of housing in Berlin and its reorganisation. On the other hand, key actors of each case were identified in order to analyse how they use the regulatory framework in order to pursue their own interests in the production of housing. This involved investment firms, housing companies, and agencies for urban renewal and neighbourhood management, and district government officials. The actors on the regulatory level together with the actors on the case level provided a wideranging picture of the reorganisation of Berlin's mode of housing provision and its uneven consequences. ${ }^{48}$

\footnotetext{
${ }^{47}$ I distinguish between key actors and informants/respondents/interviewees, whereas the key actors are the institutions or organisations involved in the process and the informants represent these organisations.

${ }^{48}$ In accordance with the conceptual model, which argues that consumption relations are determined by regulation and production mechanisms (see section 3.2), individual tenants were not interviewed. The consumption side was however still represented through tenant organisations and neighbourhood managers.
} 
Three steps were involved in the identification of relevant actors. First, research was conducted with the help of the Internet and of newspapers. Key actors in the provision of housing were identified and information on the neighbourhoods was collected. Through this, two to three actors per case could be identified and used as a starting point. Second, for each key actor, a possible respondent was identified. The aim was always to get to the manager level of the institution because it was assumed that the strategies of the actor were decided at this level. Third, the identified respondents were contacted and an interview was requested. At this stage, the potential interviewees were also asked if other key respondents could be recommended for interviews. Furthermore, at the end of each interview, the interviewee was again asked to identify other informants.

\section{Accessing informants}

This snowballing system helped to establish a network of respondents and provided an openness to identify unanticipated activities and processes. It was relatively easy to get appointments with representatives from the district and Berlin governments as well as with non-governmental organisations. Fieldwork was done during the summer which turned out to be unproblematic and an LSE letterhead proved to be a gateopener. In contrast to the public sector, it was more difficult to access actors from the private sector, such as representatives of investment firms or privatised housing companies. A first problem was to identify the right contact within a company. This was partly because private companies and especially investors do not have extended organisational structures publicised on their website. Once having established the right contact, often through other respondents, a second problem was the gatekeeper. It proved difficult to get beyond the secretary of the fund manager or of the director of a housing company. Sometimes, this was not possible at all. It proved to be much easier where personal email or phone numbers were available, or a mediating contact that could be referred to.

Another challenge with actors from the private sector was the non-disclosure information policy they often adhered to. As a CFO of a housing company pointed out during the interview: "We are shy in regards to our information policy" (ID 12, author's translation). These companies are not willing to reveal their investment strategies. Another reason for their non-disclosure may be the fact that privatised housing companies and their respective investment firms have received negative publicity in the last few years. In some interviews, the respondents did not reveal as much insider information as hoped for. Nevertheless, through building up a network of contacts and establishing trust with the actors that were interviewed, some of the representatives 
from the private sector could be accessed and information gathered. This proved to be important for gathering the complete picture of Berlin's reorganisation of its housing provision.

In the end, 30 interviews (with a total of 39 respondents) were conducted. This was sufficient in order to assess the different viewpoints on the reorganisation of Berlin's housing provision and its uneven consequences. The interviews covered representatives from all the different actors relevant to the governance of Berlin's housing provision and the specific cases. And even though the private sector might have been slightly underrepresented, there are only a certain number of interpretations of the same event (Gaskell 2000). While the first few interviews provided new and surprising insights into the topic, a saturation point was reached as more interviews were conducted. Once a point was reached where interviews became too repetitive and even a departure from the guideline proved to corroborate the existing understanding, no further interviews were conducted (Gaskell 2000). For a complete list of the interviews conducted, see appendix 1.

\section{Interviewing informants}

The interviews were mostly conducted in the office of the interviewee. There were three occasions where the person suggested meeting in a café or in a hotel. This was because these respondents did not have an office in Berlin, but had no impact on the interview process. While I felt the conversations outside of the office were more informal and also more informative, I attribute this more to the personality and position of the interviewee than to the location.

The interviews were always set up as a conversation, whereas I set the parameters and controlled the conversation, but did not intervene in the flow of it. I only intervened in order to guide the conversation where necessary. While I emphasised to the interviewees that neither their name nor their company's name will be mentioned in the thesis and that I am more interested in general processes than in the specific company itself, I encountered two respondents ${ }^{49}$ who did not want me to record the conversation. In these instances, I wrote down as many notes as I could and tried to recapture the whole interview on paper right after it happened. There is the possibility that I have missed out some details because I could not go back to the record. However, I do not think that this impacts in any way my data, since I still gathered the opinions and views of the respondent.

\footnotetext{
${ }^{49}$ One of the respondents was from a privatised housing company. The other was from the investment side.
} 
It struck me how strongly the opinions of the interviewees were shaped by ideology. This reflected the perception I got from the preliminary analysis of the media coverage of the privatisation debate of Berlin's state-owned housing companies. At the same time, it was still surprising how little detailed knowledge of the regulatory structure the respondents had and how much their position was based on their political leanings or their social milieu.

This also brought up the reflection on my own position in the interview process (Patton 2002: 329). What impact does my own political views, but also my gender, my status as a PhD student, and me as a Swiss researching a German city have on the interview process? My own political view seemed to be the least concern in the fieldwork process since I was aware of it, but I was also aware that by not commenting (negatively or positively) on anything said in the interview itself, I could hide my own point of view well enough. My gender, my status as a student as well as being Swiss, was less easy to hide. While there was in almost every conversation a hint about the Swiss-German diplomatic fight over taxation and bank secrecy going on at the time of my fieldwork, I was mostly welcomed doing research as an outsider, hopefully bringing some more objective insights into the debate. Thus, while I was seen very much as an outsider, I strongly believe that this had the advantage of being trusted as non- or less-judgemental. My status as a female student was probably the most affecting factor in the interview process. I was highly regarded when mentioning the LSE as my home-university. However, in a few interviews with private actors but also with government administration personnel, I felt being looked down upon. I do not necessarily consider that as a disadvantage in the interview process though, since it often meant that they explained processes in more detail.

An external factor that highly affected my research was the financial crisis. When I established my research project and research question, the financial crisis had not broken out yet. However, during my fieldwork, Berlin - even though less hit by the crisis because it could not fall further as many interviewees pointed out - started to feel the consequences. One interviewee, working for an investment fund, explained, for example, that he had to negotiate for a credit over six months whereas before he would have gotten the credit with one telephone call. Furthermore, the hype around investing in Berlin was extremely moderated and statistics show that the selling and re-selling of apartments stopped (see chapter 5 for an analysis on the impact of the financial crisis). Thus, the financial crisis was a specific historical event referred to in the analytical model (see section 3.2.2) that influenced the particular mode of housing provision at the time of investigation. 


\subsubsection{Participation in Conferences}

During my fieldwork time in Berlin, I also attended different conferences related to the city's housing provision. They ranged from academic conferences, industry gatherings, political symposia, and government discussion panels. This helped me, on the one hand, to build up my contact network. On the other hand, I was able to confirm and extend the understanding of the different viewpoints in the debate on Berlin's housing provision. A list of the conferences I participated in is in appendix 3.

\subsubsection{Document Collection}

A third part of my fieldwork involved the search for primary documents. I was interested in three types of documents: political and legal documents such as government and parliamentary decisions related to the changing of regulations or law in housing provision; housing market reports discussing the investment climate in Berlin's housing; and evaluation reports analysing the impact of housing policy on the social structure of the neighbourhoods studied. The document analysis was relevant for two reasons: First, it helped to establish the basic facts around regulatory changes in the provision of housing in Berlin. This proved to be crucial because interviewees were often not familiar with the regulatory details. Being myself familiar with them, it helped me on the one hand to establish mutual respect and trust with the interviewees. Second, I was able to compare the statements given by the respondents with the information from the documents. The document analysis, therefore, helped me to gain a more complete understanding of the underlying processes because I could put the interviewees' statements into perspective. Thus, for example, a statistical report on the changes of a social structure within a certain neighbourhood helped to confirm the statements made with regards to an increasing exclusion of better off tenants from this neighbourhood. There is a complete list of the documents analysed in appendix 4.

The search for political documents turned out to be not entirely satisfying because government decisions in Berlin are not public. While I was able to access protocols of parliamentary debates and decisions at the legislative level, I was not able to access the documents that involved decision-making on the executive level of Berlin's government. There is a decision by the government to change its strategy regarding the state-owned housing companies that several interviewees referred to, but either they did not know the exact content of it themselves or they were not able to give me the document. The same applied to the sales contract between private investors that bought the state-owned housing company from Berlin's government. While the statements from the interviews referring to the government decision and the purchase contracts often pointed in the same direction, and therefore started to confirm one another, I was not able to confirm the statements through the documents themselves. 
While some documents proved to be helpful in triangulating the findings from the interviews, the lack of access to other documents meant that it was not always possible to yield complementary information through this method and I had to rely on triangulation through interviews.

\subsection{Analysis of the Collected Data}

For the analysis of the collected data, I relied on Kelle (1995) and Prein and Kelle (1995). Through a method of coding, I aimed for reduction of information. The purpose was to reveal the different processes within the reorganisation of Berlin's mode of housing provision that have occurred, the social relations between the key actors, and the viewpoints of the respondents with regards to each of the processes and its consequences. For this data reduction process, the software AtlasTi helped me to organise the data once all the interviews were transcribed. The programme also assisted me with the coding process and the reduction of information.

A three-step approach was chosen. First, I identified key themes, some of them were concepts that emerged from the theoretical model and some of them were surprise discoveries in the fieldwork process. Six interviews were test-coded in order to establish the main codes. However, I left the coding structure open enough that unexpected themes could still be added that would have been lost otherwise. Thus, a "rough preliminary coding scheme" was established along the previously developed theoretical model, but modified in line with new emerging elements (Prein and Kelle 1995: 63).

Second, all of the interviews were coded using the same coding structure. After this first revision of the interviews with a rather detailed coding, the process was repeated in order to identify the main actors and their relations with the themes that were revealed in the first run. This helped me to see which of the key actors were involved in the different themes and how they perceived the processes. An example would be the code "PS-PR: increasing rent levels" that meant the privatisation process (PS) led to increasing rent levels within privatised housing companies' (PR) housing stock. If another respondent claimed the opposite, it was also coded in order to acknowledge and identify their different viewpoints.

Third, networks of the established codes were created. Networks are graphs that link the different codes and their content with each other. This helped to "give account of the emerging theory by displaying its main categories" (Prein and Kelle 1995: 66). I created four different networks under the themes of 'State Restructuring', 'Regulation', 'Institutional Investors', and 'State-owned Housing Companies'. This served to identify relations between the codes in order to understand power relations. The relation between codes was identified as either opposing each other, as being associated 
with each other, or as caused by each other. See appendix 5 for the four networks. Through this three-step approach, I was able to identify the key processes and actors, and the respondents' viewpoints.

\section{Conclusion}

This chapter established the methodological approach in order to tackle the question of how a particular mode of housing provision creates processes of uneven development. Using a critical realist perspective, the necessary relations of a particular mode of housing provision such as regulation, production, and consumption as well as the contingent relations of the spatial and temporal context have been identified in order to analyse the reorganisation of Berlin's mode of housing provision. The second part of the chapter dealt with the practical process of research and the challenges involved in fieldwork.

The next chapters turn to the analysis of the reorganisation of Berlin's state-owned housing provision. The first of the empirical chapters (4) analyses the historical and spatial development of Berlin's provision of housing structure in order to contextualise the analysis. Having established the context, the three following chapters (5-7) analyse the different processes of the reorganisation of Berlin's mode of housing provision and its uneven consequences. First, the process of privatisation of state-owned housing companies and estates, and the impact of institutional investors on the provision of housing is analysed (5). Second, the reformation of the remaining state-owned housing companies and its consequences on how they operate is investigated (6). And third, the abandonment of supply-side subsidies is under scrutiny, looking at the impact this had on the previously established production relations of institutional investors and state-owned housing companies (7). 


\section{Historical and Spatial Development of Berlin's Housing}

Current regulatory changes have to be contextualised within historical developments because they are embedded within inherited legacies produced by specific social and political struggles (Brenner and Theodore 2002). This is especially significant in regards to the built environment and the provision of housing, since housing was built at one point, evolved sequentially, and is continued to be used today (Sayer 2000: 123; see also section 3.2.2). The high production costs and the long-term use of housing imply that the historically developed housing, which still exists, is pivotal to understanding current changes in the mode of housing provision. With the purpose to analyse the transformation of Berlin's mode of housing provision and its uneven mechanisms in the last decade (see chapters 5-7), this chapter looks at the historical development of Berlin's housing provision before the mid-1990s.

The chapter builds the argument that the evolution of Berlin's housing provision, over the past century, created particular conditions which play a significant role in the processes of uneven development triggered through the transformation of Berlin's housing provision in the last decade. In order to understand how the reorganisation of Berlin's mode of housing provision created processes of uneven development, the chapter addresses the following question: How have different types of housing spatially, physically, institutionally, and socially developed?

Housing is a highly heterogeneous and inflexible good (Krätke and Borst 2000: 158 et seq.). Four characteristics are crucial to its understanding. First, the spatial location of housing is significant due to its immobility. This creates spatially differentiated market segments. Second, the institutional form is important for understanding price mechanisms. Three forms are distinguished: Owner-occupied, private rented, and social rented housing. ${ }^{50}$ Third, diverging physical characteristics such as age, quality, design, and size create factually differentiated market segments. And fourth, the heterogeneous character of housing influences the social structure of the occupants. The highly segmented housing market means that there is not equal tenant access to all the housing units. This is what makes housing a good reflection of the socio-spatial urban structure.

\footnotetext{
${ }^{50}$ Berlin's housing market is dominated by social and private rented housing. 86.5 percent of the housing stock is rented. The percentage of rented housing is especially high in inner city districts (Mitte, Friedrichshain-Kreuzberg, Lichtenberg) with more than 94 percent of rented housing. While there has been a successive increase in home ownership, from 11 percent in 2000 to 13.5 percent in 2008 (Investitionsbank Berlin 2010), it remains relatively small and is therefore largely neglected in the analysis.
} 
The chapter investigates these characteristics along three different types of housing: (1) late $19^{\text {th }}$-century block developments, (2) Nineteen Twenties, Thirties, and Fifties row developments, and (3) post-war high-rise developments. ${ }^{51}$

- Block developments: built during the late $19^{\text {th }}$-century, block developments are predominantly located within an urban belt around the historical core of the city.

- Row developments: built from the beginning of the 1920s through the 1950s, row developments are located within the train loop of the inner city and at the periphery of West Berlin.

- High-rise developments: built in East and West Berlin from the 1960s onwards, high-rise developments are located in the outskirts of Berlin.

Map 4.1 shows Berlin's housing structure with the three types of housing. ${ }^{52}$

The chapter is structured along these three types of housing, which still play a significant role in Berlin's housing provision today. The chapter investigates their historical development during the division of the city and discusses their spatial, physical, institutional, and social legacy that has implications for the transformation of Berlin's mode of housing provision analysed in the following chapters 5,6 , and 7 . This new approach, which contrasts with a conventional chronological approach to investigate the historical development of Berlin's housing provision, exposes the question of how regulation, production, and consumption mechanisms affect the three housing types. The chapter ends with a more detailed spatial analysis of Map 4.1 and raises the questions that will be addressed in the following chapters.

\footnotetext{
${ }^{51}$ These three types are based on the broadest summary categorisation by the Senate Department for Urban Development for the Urban Structure of the Berlin Digital Environmental Atlas (Senatsverwaltung für Stadtentwicklung 2008). The English terms used here are based on the official translation by the Senate Department for Urban Development.

${ }^{52}$ The category of low buildings with yards is a fourth category distinguished by Berlin's Senate Department for Urban Development's broadest summary categorisation. This category is relatively heterogeneous with one to two storey row houses built before 1945, single family houses built after 1945, villas, and mansions with surrounding land. The buildings in this category take up significant space. They do however play an inferior role in the provision of housing structure because of their lowdensity. Moreover, the housing units in this category are often owner-occupied. This category has therefore been neglected.
} 


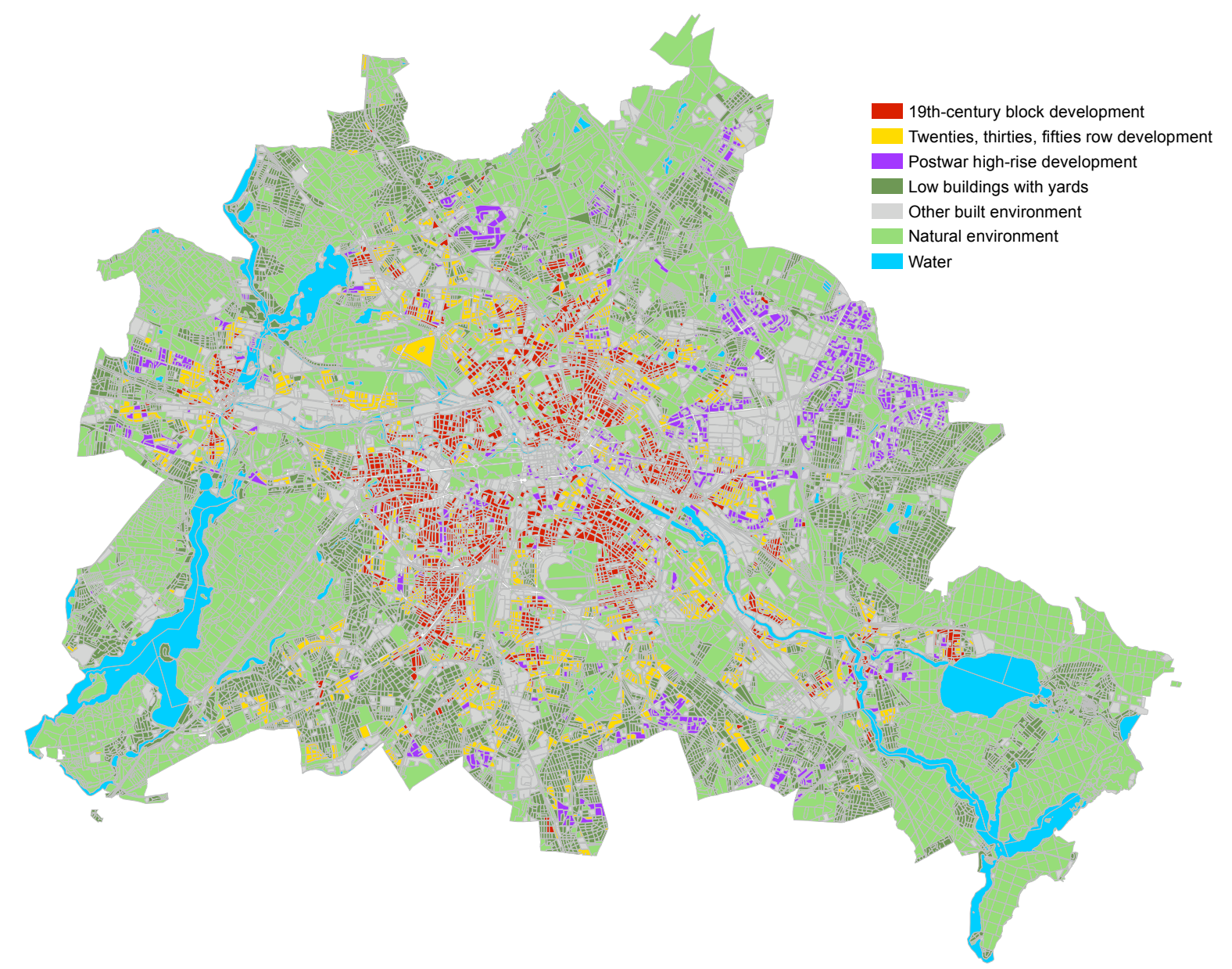

Data set: Informationssystem Stadt und Umwelt (ISU) der Senatsverwaltung für Stadtentwicklung Berlin

\subsection{Late $19^{\text {th }}$-Century Block Developments}

The block developments ${ }^{53}$ are closely linked to Berlin's urbanisation and the city's rise to a modern metropolis. At the end of the $19^{\text {th }}$-century, Berlin underwent a rapid industrialisation causing exceptional population growth. During this time period, also referred to as the Wilhelmine Berlin, housing construction predominantly occurred in the form of block developments (see Photo 4.1 and Photo 4.2). These developments were built starting in the 1870 s resulting from public street planning, construction law, and private investment (Schwenk 2002). While previous housing was primarily built by landowners, private corporations started to invest in new housing, hoping to make high profits (Häußermann and Kapphan 2002). The president of the police was in

\footnotetext{
${ }^{53}$ Late $19^{\text {th }}$-century block developments are also referred to as tenement buildings (Mietskasernen).
} 
charge of planning and building regulations and decreed strict rules regarding the form of housing structure, leading to uniform five-story buildings. ${ }^{54}$

The block developments were built along a belt that surrounded the urban core of the city at the time. ${ }^{55}$ Railway lines defined the exterior boundary of this belt. In some cases though, this boundary was crossed and the developments went beyond the railway lines (Schwenk 2002: 208 et seq.). The developments are characterised by their closed structures with a front house, side and rear wings. Several rear wings follow each other creating a sequence of courtyards (see Photo 4.1).

With this housing structure, the police president at the time wanted to avoid the development of working class slums within the city-centre. The cheaper and smaller apartments in the rear wings that were very densely built and the more generous apartments in the front buildings created a social mixture within each block. However, this structure did not prevent the development of working class neighbourhoods in the North and East of the city. In these neighbourhoods, the apartments were generally smaller in size and the rear wings of the blocks were more densely structured. The petty bourgeoisie and craftsmen inhabited the front buildings while unskilled workers lived in the rear wings. In western districts such as Charlottenburg and Wilmersdorf, the apartments within these block developments were built more generously. In these districts, front buildings were often connected with the side wings, constituting apartments of five rooms or more. The bourgeoisie occupied these apartments and the people working in the trades or in the public sector lived in the rear wings of these houses (Häußermann and Kapphan 2002; Bernet 2004). Häußermann and Kapphan (2002: 35, author's translation) call this development "a 'social mix' within segregated structures".

\footnotetext{
${ }^{54}$ See Bernet (2004) for a discussion on the 'Hobrecht-Plan' (named after the head of the commission in charge of the construction police in Berlin - the urban planning department at the time) and how its assessment has changed over the past 150 years.

${ }^{55}$ A city wall that marked the fiscal boundary delimited the urban core. The wall was however torn down in 1860 (Schwenk 2002: 112).
} 
This image has been removed, as the copyright is owned by another organisation.

At the beginning of the 1910s, the block developments came under criticism from the general public, but also from the professional planning guild. ${ }^{56}$ Besides planning and aesthetic critiques, the block developments were criticised for their increasingly deteriorating social conditions (Häußermann and Kapphan 2002). Private corporations were not capable of producing enough dwellings for the growing population. Often, rear buildings were overcrowded leading to sanitary deficits. New solutions for a more humane housing provision to accommodate the growing working class population had to be found. This resulted in the state-led construction of row developments during the Twenties, Thirties, and Fifties (see section 4.2 below). At the same time, the block developments became increasingly neglected until their physical reconstruction which began in the 1970s.

After the Second World War, during the division of the city, the two governments had diverging approaches on handling the old block development housing stock in the inner city. West Berlin's government aimed to tear down the block developments and replace them with new ones. The government came however under increasing pressure from the population to preserve and renovate them. East Berlin's government mainly abandoned the old block development housing stock. The particular way in

\footnotetext{
${ }^{56}$ The German term Mietskaserne (tenement) for this housing type manifests itself in this critique. The term is still used, but no longer with this negative connotation. See Häußermann and Kapphan (2002) for a discussion of the different critiques.
} 
which the two governments dealt with the block developments influences the provision of housing structure still today. The following sections analyse the diverging paths in more detail.

\subsubsection{Sensitive Urban Renewal of Block Developments in West Berlin}

In the immediate post-war period, the government of West Berlin had a rather ambiguous position regarding the late $19^{\text {th }}$-century block developments. On the one hand, public subsidies existed to remove the stucco on the facades because it was considered to be out-of-date. On the other hand, there were efforts to protect the few remaining historical sites that were not bombed out during the war. However, despite state subsidies to renovate the block developments, private owners rarely had the means to renovate their properties. The housing stock of Wilhelmine Berlin therefore continued to decay (Bremer et al. 2007).

At the beginning of the 1960s, Berlin's government decided to replace these block developments. West Berlin's government designated several neighbourhoods with block developments for demolition. This was partly motivated by the aim to support a construction industry that suffered from a vanishing interest to invest in Berlin. The goal was to replace the block developments with socially financed high-rise buildings (see section 4.3.1 below). State-owned housing companies led this urban renewal. They had to buy the apartments and a whole block had to be emptied before it could be demolished. It usually took 13 years from the announcement to the demolition phase due to the rigidity of the demolition regulations.

The social structure of the inhabitants of this type of housing remained relatively mixed until the announcement of the demolition at the end of the 1960s. The announcement however, fostered an exodus of the more mobile population, mostly to the post-war high-rise developments in the periphery (see section 4.3.1 below). During the time period between the announcement and the actual demolition itself, the apartments were sublet to migrant workers that were expected to return to their home country. The proportion of immigrants, mostly from Turkey, increased quickly, especially within the districts of Wedding and Kreuzberg. Because immigrants were excluded from the newly built (social) housing units at first, they remained within the old block developments. Besides the immigrant population, students also increasingly squatted the block developments.

Towards the end of the 1960s, however, tenants began to protest against this form of 'comprehensive renewal' (Flächensanierung). The squatters were the first ones to protest against the demolition of these housing units (Häußermann and Kapphan 
2002). This protest led to a rethinking at the political level which resulted in the reorientation of urban renewal to preserve the built environment and social structures of the block developments (see Photo 4.2). The state started subsidising the renovation of these neighbourhoods (Häußermann and Kapphan 2002; see also chapter 7.2). At first, state-owned housing companies implemented this new form of 'sensitive urban renewal' (behutsame Stadterneuerung); later, private landlords also benefitted from the state subsidies to renew the housing themselves.

Photo 4.2: Renovated Front Buildings in a late $19^{\text {th }}$-Century Block Development Neighbourhood (here Chamissoplatz, Kreuzberg)

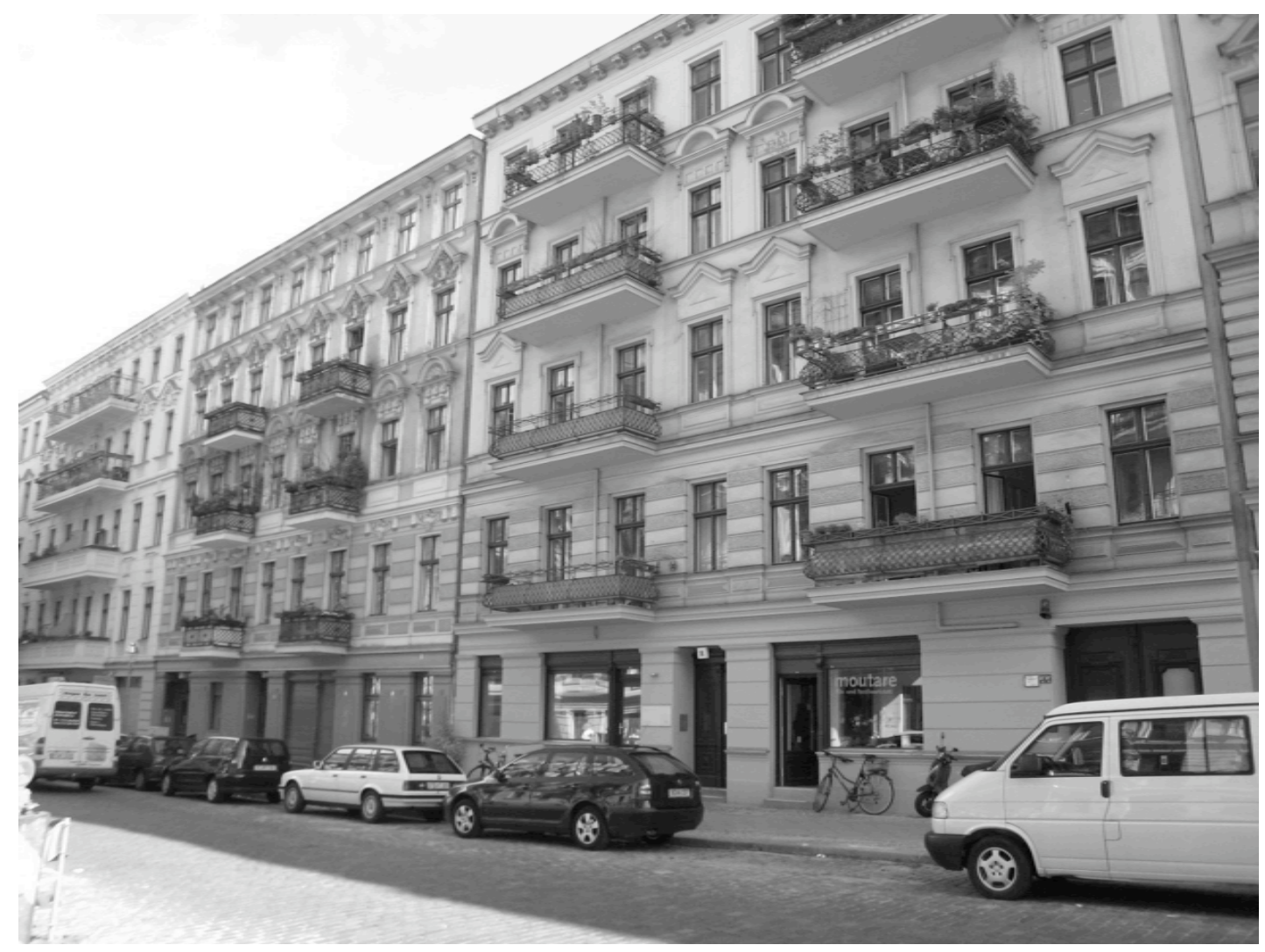

(C) Sabina Uffer

The sensitive urban renewal strategy significantly increased the physical quality of the block developments in West Berlin. Through the demolition of some of the rear wings, the block structures were opened up, and more light was able to reach the remaining buildings. This made living in the rear wings more comfortable because the apartments were better protected from street noise. The high ceilings, the wooden floors, and the large rooms also contributed to the increasing popularity of this housing type. 


\subsubsection{Complete Abandonment of Block Developments in East Berlin}

In East Berlin, the situation of the housing stock from Wilhelmine Berlin was different. The block developments were considered as a "relic from the former capitalist system" (Kemper 1998: 18) and were mostly abandoned. At the same time, new prefabricated housing estates were built, first in the bombed out inner city areas and later in the outskirts of the city (see section 4.3 .2 below).

During the GDR era, private land ownership, and therefore housing, was abandoned. Rent levels in the existing housing stock were kept at pre-war levels and allocation was organised by the state. Even where the ownership of housing formally remained, the owners could not rent the housing cost-effectively. There was no possibility of profit-making from renting apartments. Owners who left for West Berlin either donated the house to the state or were expropriated (Häußermann and Kapphan 2002: 179).

A lot of apartments were emptied due to the increasing neglect of this housing stock. Others were occupied by young people who did not want to move out to the monotonously newly built housing (see section 4.3.2 below) and considered this form of living more attractive (Häußermann and Kapphan 2002: 68). There were a lot of critical intellectuals and artists among them. Due to a politically motivated allocation policy, the old neglected housing stock was also inhabited with socially discriminated citizens. These were, for example, the elderly and people who applied for an exit permit. A third group consisted of families on the waiting list for the new housing (Häußermann and Kapphan 2002: 77 et seq.). The social structure was therefore relatively heterogeneous.

Only since the 1980s did some block development renovations take place in the shadow of the large-scale housing construction at the periphery (see section 4.3 .2 below). The initial efforts to modernise the block developments could however not stop the decay of this housing in East Berlin. The construction industry of the GDR was too focused on new buildings. This made a reorientation of the necessary capacities for the modernisation of the old housing stock difficult. However, also in East Berlin, experts and increasingly residents of the block developments mostly in the district of Prenzlauer Berg, demanded a rethinking towards the preservation of block developments. It was however only from the mid-1990s onwards that this housing stock got renewed on a large scale (see section 7.2).

After reunification, the owners of the housing who were expropriated either during the Nazi-Regime or during the GDR could reclaim their property based on the 
national law for unresolved property questions. ${ }^{57}$ Restitution claims were made for most of the inner city areas in East Berlin. ${ }^{58}$ Solving restitution claims often took several years, delaying the modernisation process immediately after reunification. ${ }^{59}$ However, most previous owners were no longer interested in the housing and sold it relatively quickly after restitution. Individuals, owners' associations, and small-scale private investors bought the majority of this housing stock. The housing stock without restitution claims came into the ownership of state-owned housing companies (Häußermann et al. 2002).

The analysis of the different pathways that late $19^{\text {th }}$-century block developments underwent in East and West Berlin shows that the physical, but also institutional and social conditions of this type of housing in the mid-1990s depended on their location. In West Berlin, the block developments were increasingly renovated through state subsidies. They were either in the ownership of state-owned housing companies or small private landlords. The tenant structure constituted of tenants that were not able or did not want to move into newly built social housing, such as immigrants, students, and elderly people. In East Berlin, the block developments, in contrast, were mostly decaying. Through the restitution process, they were transferred to small-scale investors or remained in the ownership of state-owned housing companies. A high social mix, from intellectuals, and artists to families and elderly people made up the tenant structure. These previous rounds of uneven development between East and West Berlin's $19^{\text {th }}$-century block developments raises the question of how the transformation of the mode of housing provision starting in the mid-1990s played out under these circumstances. How do regulation, production, and consumption relations occupy and transform these spatial characteristics?

The following section turns towards the second category of the three housing types, the Nineteen Twenties, Thirties, and Fifties row developments, analysing their spatial, physical, institutional, and social development.

\footnotetext{
${ }^{57}$ Gesetz zur Regelung offener Vermögensfragen. In West Germany, the restitution of expropriated housing during the Nazi era had already taken place earlier.

${ }^{58}$ In the district of Prenzlauer Berg, for example, restitution claims were made for 90 percent of the properties (Häußermann et al. 2002). The high amount of restitution claims in inner city areas was due to the relatively high percentage of Jews owning this type of housing before 1933. It was however also due to the fact that the GDR expropriated the housing for the substitution of urban infrastructure (Häußermann et al. 2002).

${ }^{59}$ The housing companies, which managed the housing stock during the restitution process, did not have any incentives to modernise, since most likely restitution meant that they had to return the housing to its rightful owner (Häußermann et al. 2002).
} 


\subsection{Twenties, Thirties, and Fifties Row Developments}

The 1920s and 1930s row developments are closely linked to the origins of statesubsidised housing provision in Berlin. The collapse of the privately funded housing industry that built the $19^{\text {th }}$-century block developments until the Great War became a major challenge for Berlin during the Weimar Republic (Haspel and Jaeggi 2007: 12; see also section 4.1). The urgent housing shortage that resulted in the overcrowding of block developments demanded state intervention. Social and planning reforms of the Weimar Republic targeted the misery of the working class districts. These reforms had two major impacts on the provision of housing.

A first impact concerned the ownership of the development and management of the housing. The reforms introduced the publicly financed housing provision subject to certain regulatory conditions. This generated a different structure of housing developers (Burkhardt 1999: 26). It marked the beginning of non-profit housing construction (Gemeinnütziger Wohnungsbau), which continues to impact the mode of housing provision until today (see chapter 6). In comparison to the small-scale private investors that built the tenements of the Wilhelmine Berlin, the non-profit housing companies had the capacity to build compact housing estates with several hundred dwellings. Considering the non-profit housing companies as a solid partner, the state supported the construction of housing (Bernhardt 1999: 59). In exchange, these housing companies, restricted in their profit-making, built affordable housing for the masses. Between 1925 and 1930, 135,000 apartments were built in Berlin, of which 75 percent were built under the principle of non-profit housing construction (Bernhardt 1999: 59; Häußermann and Kapphan 2002: 49). In this time period, state-owned housing companies were founded and established as non-profit companies. These state-owned housing companies, even though transformed from the 1990s on, still play a major role in Berlin's mode of housing provision (see chapter 6).

A second impact of the social and planning reforms concerned the design of the housing. Avant-garde architects ${ }^{60}$ started to design high quality housing at affordable prices. These row developments soon became nationally and internationally acclaimed for their modern style architecture. Less dense structures with a high amount of green areas characterised them. Even though the size of the apartments was not necessarily bigger than the size of those in a block development, they had higher living standards with modern facilities (such as bath, kitchen, hot water, central heating

\footnotetext{
${ }^{60}$ These architects (Gropius, Mies van der Rohe, Taut are some of the best-known among them) were later canonised under the term International Style and they became famous for their aesthetics of functionalism. See Hake (2008) and Haspel and Jaeggi (2007) for a more in-depth discussion of the architectural features of these housing estates.
} 
system, and balcony). Hake (2008: 106) described this type of housing as "[t]he simple materiality of glass, iron, and concrete announced the levelling of social and national differences, while flat roofs, unadorned façades, and horizontal window bands captures the dynamism of the times in this clearest manifestation of the new mass body" (see Photo 4.3).

The row developments of the 1920s and 1930s were built within the inner city loop demarcated by the railway lines. Often, these developments filled sites of existing gaps within the urban structure. The more centrally located row developments were densely built with open structures and a lot of greenery (see Photo 4.3). More peripheral housing estates were integrated in park-like areas. The row developments created residential areas introducing a clear functional division between living and working (Haspel and Jaeggi 2007: 9).

White-collar employees from the private and public sector and better off manual workers mainly occupied these new housing estates. The lower working class did not have access to these estates for three reasons. First, the housing was often constructed by corporations owned or closely related to companies, which provided housing for their white-collar employees. ${ }^{61}$ Second, despite subsidies, rent levels were comparably high. And third, the allocation through the housing office was discriminating against families and households that were "perceived as less desirable" (McElligott 1992: 107). ${ }^{62}$

\footnotetext{
${ }^{61}$ For example Siemensstadt (Siemens-City).

${ }^{62}$ For a more detailed account of the historical development of housing provision in the first part of the Twentieth century, see Häußermann and Kapphan (2002) and Puchta and Koop (2008).
} 
Photo 4.3: Bird's Eye View of a Twenties Row Development (here Carl Legien Estate, Prenzlauer Berg, Constructed between 1928 and 1930)

This image has been removed, as the copyright is owned by another organisation.

During the Second World War, the provision of housing mostly gave way to the construction of representational buildings for the Nazi Regime, despite continuous housing shortages (Schäche 1999: 194). The housing problem became even more pressing after the war when Berlin struggled with the destruction. After the Second World War, Berlin was badly bombed ${ }^{63}$ out and suffered from a structural housing shortage. Physical reconstruction was therefore an urgent task. In the immediate years after the war repairing existing buildings was a priority. Private investment was however scarce. State intervention was therefore considered essential to the rebuilding of the city. The increasingly divided city followed however slightly different approaches, not only with regards to the renewal of the old housing stock (as seen in sections 4.1.1 and 4.1.2 above), but also with regards to the construction of new housing. The following sections explore the early post-war construction of housing that was, at least in West Berlin, still dominated by row developments.

\footnotetext{
${ }^{63}$ The estimations of destruction vary widely from between 10 and 20 percent of all buildings that were completely destroyed and around 70 percent that were partially destroyed (Sewing and Hannemann 1999: 208).
} 


\subsubsection{Continuation of the Modern Style Row Developments in West Berlin}

In West Berlin, row developments continued to be built after the Second World War, however, under a slightly changed institutional form. Housing subsidies orchestrated on the national level became even more pivotal than during the interwar period. State intervention was based on legal regulations and direct economic means. The legal regulations were dominated by rent regulations. ${ }^{64}$ Direct economic intervention was accomplished through supply-side subsidies that were going into housing construction. The housing subsidy system that was implemented in this early post-war period continues to influence Berlin's mode of housing provision today.

The immense housing shortage and the lack of private investment led to a highly subsidised housing system, a considerable part being financed with special Berlin subsidies from the national government and the Western Allies. With the First Housing Construction Act that West Berlin adopted from the national government in 1951, ${ }^{65}$ the city started the housing subsidisation at a large scale in order to remedy the shortage and provide housing for a broad cross-section of the population. ${ }^{66}$ State-financed housing became an essential part of the housing provision. Between 1952 and 1961, 90 percent of the new housing construction was social housing and non-profit housing companies built 39 percent of it (Hanauske 1999).

In contrast to the Weimar Republic where non-profit companies exclusively undertook the construction of subsidised housing (see section 4.2 above), the Housing Construction Act entitled all house builders to receive government assistance for a certain time period - either through direct subsidies or low interest loans - in return for rent ceilings and occupancy control. Once the government assistance was paid back, the housing units became private property (see also section 7.1 ). ${ }^{67}$

\footnotetext{
${ }^{64}$ Because of a dramatic housing shortage - a lack of six million dwelling units after World War II -, there was a system of housing control where rents were frozen at pre-war levels and letting of units was done by local housing offices which alone were responsible for allocation (Heinz 1991). This control system was removed in 1960 (Gesetz über den Abbau der Wohnungszwangswirtschaft). Only in 1963 were new rent regulations introduced (Egner et al. 2004). New tenant protections were introduced as part of rent regulations in 1971 (Heinz 1991). In certain cities however, the termination of rent control for the old housing stock was postponed. In West Berlin, this was not abolished until 1987 (Heinz 1991; Krätke and Borst 2000).

${ }^{65}$ With West Berlin's implementation of the national Housing Construction Act in 1951, the city became integrated in the structure of housing provision of West Germany.

${ }^{66}$ Until the beginning of the 1950s, the repair of the still functional dwellings had priority over new construction. However, due to a lack of material and skilled workforces, the immense housing shortage could not be remedied in West Berlin.

${ }^{67}$ Direct government loans with no, or reduced, interest rates were gradually curtailed in favour of capital market money (Heinz 1991).
} 
This form of state intervention helped to augment the housing supply at a large-scale when private investors were not able to construct at a sufficient enough pace on their own. From the very beginning however, state intervention was viewed as an emergency and temporary measure until the free market could take over again. A withdrawal of the state "in favour of the free forces of the market and of property formation" was therefore pre-programmed (Novy 1991: 20; see also Heinz 1991).

As mentioned, the housing during this period was still predominantly built as row developments. In contrast to the 1920s and 1930s, the 1950s row developments were mostly built in the periphery due to the higher prices in the inner city, but also because the open structure of these developments allowed no interaction with the historical urban structure of the built environment. Only towards the mid-1950s, were row developments also built in inner city areas. They were mostly linked to the comprehensive renewal, meaning the demolition of old block development housing (see section 4.1.1 above) although these projects were few.

With regards to their physical form, the 1950s row developments did not incorporate new urban visions. Second-rate architects have copied the open structures of the 1920s and 1930s developments, which had long become standardised. The apartments were relatively small and had a higher standard than the rest of West Germany due to the higher subsidies (Sewing and Hannemann 1999: 217 et seq.). As with the earlier row developments, the 1950s row developments were built as residential estates segregated from other functions such as employment and retail. None of the estates had more than 2000 units. In comparison to the 1920s and 1930s row developments, the 1950s row developments soon became criticised for their moderate modern style, being too monotonous, too functional, and too small. At the same time, the rent levels of the social housing units were higher than the average rent levels in Berlin due to the relatively high costs for land and construction (Hanauske 1999: 101).

\subsubsection{Socialist Realism Replaced Row Developments in East Berlin}

The ideological position of the GDR, created especially at the beginning of the division a different form of housing. Later, the two forms of housing provision became surprisingly convergent (see section 4.3 below). However, at the beginning, the rivalry between the two cities was also fought out on the grounds of housing provision. Only very few 1950s row developments were built in East Berlin. The GDR government discredited the housing model of the 1920s and 1930s row developments that was at the time initiated as a modern, social, and functional housing model. The success that this model gained in North America turned the 1920s and 1930s row devel- 
opments into a capitalist housing model, which was no longer acceptable to the GDR government (Sewing and Hannemann 1999: 213).

Socialist realism propagated the integration of "habitation, recreation, consumption, and political self-projection in the public realm" (Sewing and Hannemann 1999: 213; author's translation). This meant that living took place in the inner city. Housing was constructed as "palace-like" high-rises with retail spaces on the ground floor. Apartments were generously sized with luxurious standards (Sewing and Hannemann 1999: 214; author's translation). This led to the construction of the Stalin-Allee, today's Karl-Marx-Allee in East Berlin (see Photo 4.4).

\section{Photo 4.4: Bird's Eye View of Socialist Realist Housing in East Berlin Built Between 1952 and 1960 (here Karl-Marx-Allee, Friedrichshain and Mitte)}

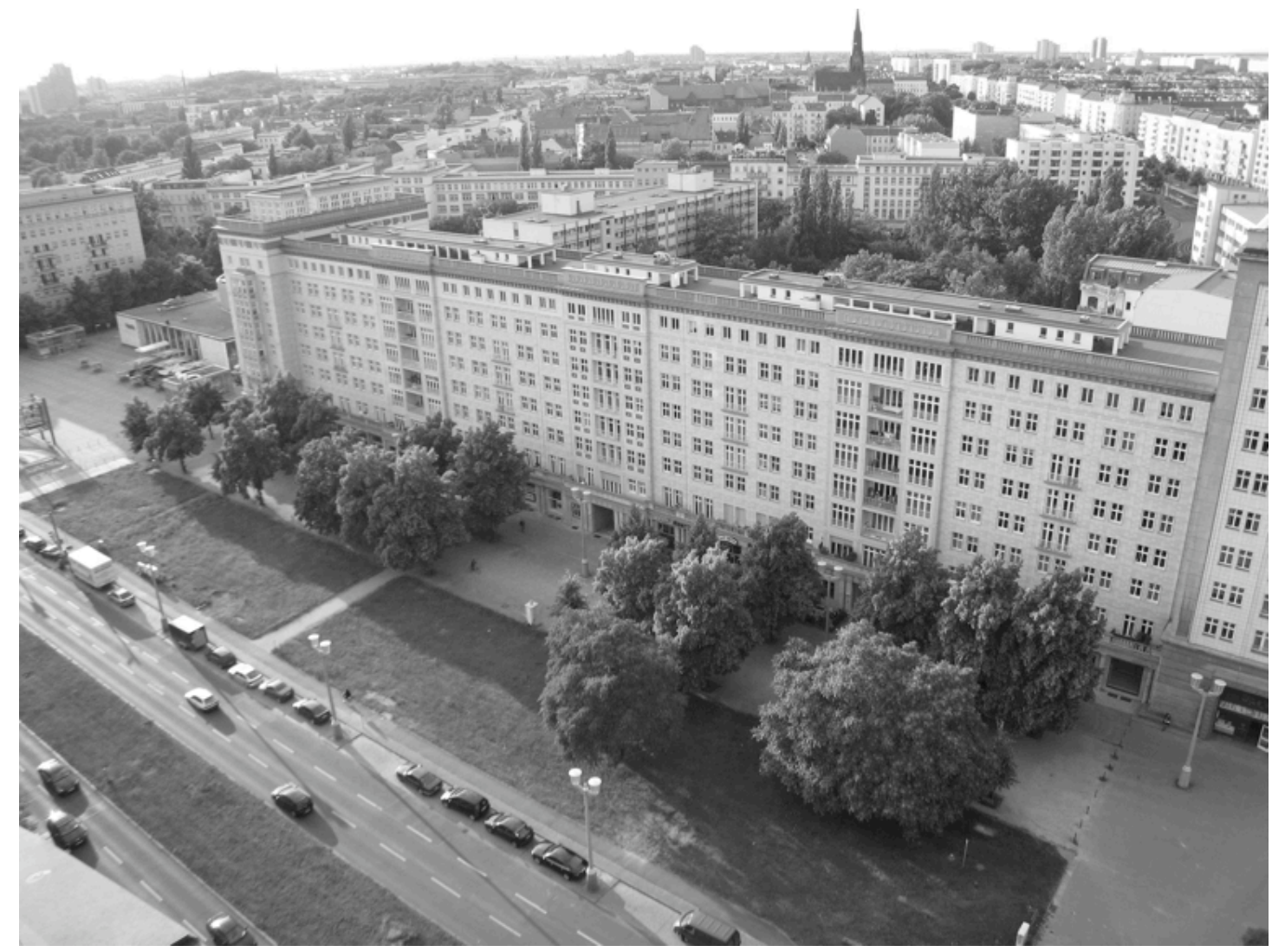

(C) Sabina Uffer

The luxurious standard of this socialist realist model of housing provision could however not been kept up for long. Already from 1954 onwards, the GDR government reoriented its mode of housing provision. While the new technology of the prefabricated slabs was already developed in the 1950 s, it took until the 1970 s to massproduce them at a large scale (see section 4.3 below). 
In the mid-1990s, the Twenties, Thirties, and Fifties row developments were in rather desperate condition. Because subsidies were paid back, they were no longer part of the social housing stock, but integrated into the free market. They were rarely upgraded to a newer housing standard and needed urgent renovation. There was however a clear difference between the Twenties and Thirties developments and the Fifties developments. The Twenties and Thirties row developments were centrally located. The Fifties row developments, in contrast, were mostly located in the urban periphery. Moreover, while the former were increasingly celebrated for their historical significance as a representation of modern design, ${ }^{68}$ the latter degenerated into insignificance. Row developments have continued to be built in one form or another until today (see case of High-Deck-Siedlung, section 3.3.2). However, none of the post-war built row developments gained the same cult status of the Twenties and Thirties row developments. How did these differences in location and popularity play out under the transformed mode of housing provision in the last decade? How did the fact that the Twenties and Thirties as well as the Fifties row developments needed renovation affect the regulation, production, and consumption relations?

The analysis of the Twenties, Thirties, and Fifties row developments illustrate the rise of state-led housing provision whose legacy continues to play a significant role in today's mode of housing provision in Berlin (see chapters 5-7). Within both parts of the city, the government played an essential role in the construction of these housing estates. In East Berlin, construction was directly organised by the state. In West Berlin, construction of the housing estates was almost entirely supported by social housing subsidies. Both states gave high importance to housing as part of their welfare provision (Sewing and Hannemann 1999). This institutional form of housing provision peaked with the development of new urban visions at the edge of both cities: the postwar high-rise developments. The next section turns towards the analysis of this third type of housing.

\footnotetext{
${ }^{68}$ Six of the Twenties and Thirties row developments have been designated with UNESCO World Heritage Status in 2008.
} 


\subsection{Post-war High-rise Developments}

From the 1960s onwards, the urban visions of East and West Berlin started to converge. These new planning visions appeared in the form of post-war high-rise developments. In West Berlin, the focus was no longer on the development of single housing estates such as row developments, but the construction of large-scale housing estates with high-rise developments. From the mid-1970s onwards, East Berlin solved the problem of housing shortage similarly, but on an even larger scale. The high-rise developments in East and West resemble each other also with regards to the technological approach. Both applied prefabricated slabs to construct different entities within a large-scale housing estate, which covered whole neighbourhoods. Moreover, in East and West Berlin, the post-war high-rise buildings were constructed to accommodate small families and integrated different facilities into the neighbourhoods.

\subsubsection{Three New High-rise Housing Estates in West Berlin}

Towards the end of the 1950s, the national housing subsidies system started to change. With the Second Housing Construction Act in 1956, the national state also subsidised home ownership for low income households (Egner et al. 2004). At the same time, the free housing market was indirectly promoted through tax-deductible amortisations (see Stimpel 1990). Additionally, starting from 1965, demand-side subsidies supported tenants on lower incomes and therefore strengthened their position in the housing market (Egner et al. 2004). ${ }^{69}$ Supply-side subsidies however continued to play an important role. In the $1960 \mathrm{~s}, 85$ percent of the housing construction was still state subsidised (Hanauske 1999: 113; see also chapter 7). As in the 1950s, the non-profit, mostly state-owned housing companies, predominantly acted as developers of largescale housing estates.

Starting in the 1960s, new urban visions were constructed in the outskirts of West Berlin (see Photo 4.5). Under the direction of state-owned housing companies, three large-scale housing estates with high-rise developments were built. The names of these housing estates made clear that they covered whole neighbourhoods. The Gropiusstadt and the Märkisches Viertel each with 18,000 housing units, and the Falkenhagener Feld with 11,500 housing units were finished between 1962 and 1975. These estates were characterised by their high density and the integration of infrastructure such as schools and shopping facilities (Hanauske 1999: 105). However, while the neighbourhoods were equipped with these types of facilities, they often lacked job opportunities within the area.

\footnotetext{
${ }^{69}$ For a more detailed account of the different subsidy systems and how they developed over time, see Stimpel (1990), Norton and Novy (1991), Egner et al. (2004), or Kofner (2004).
} 


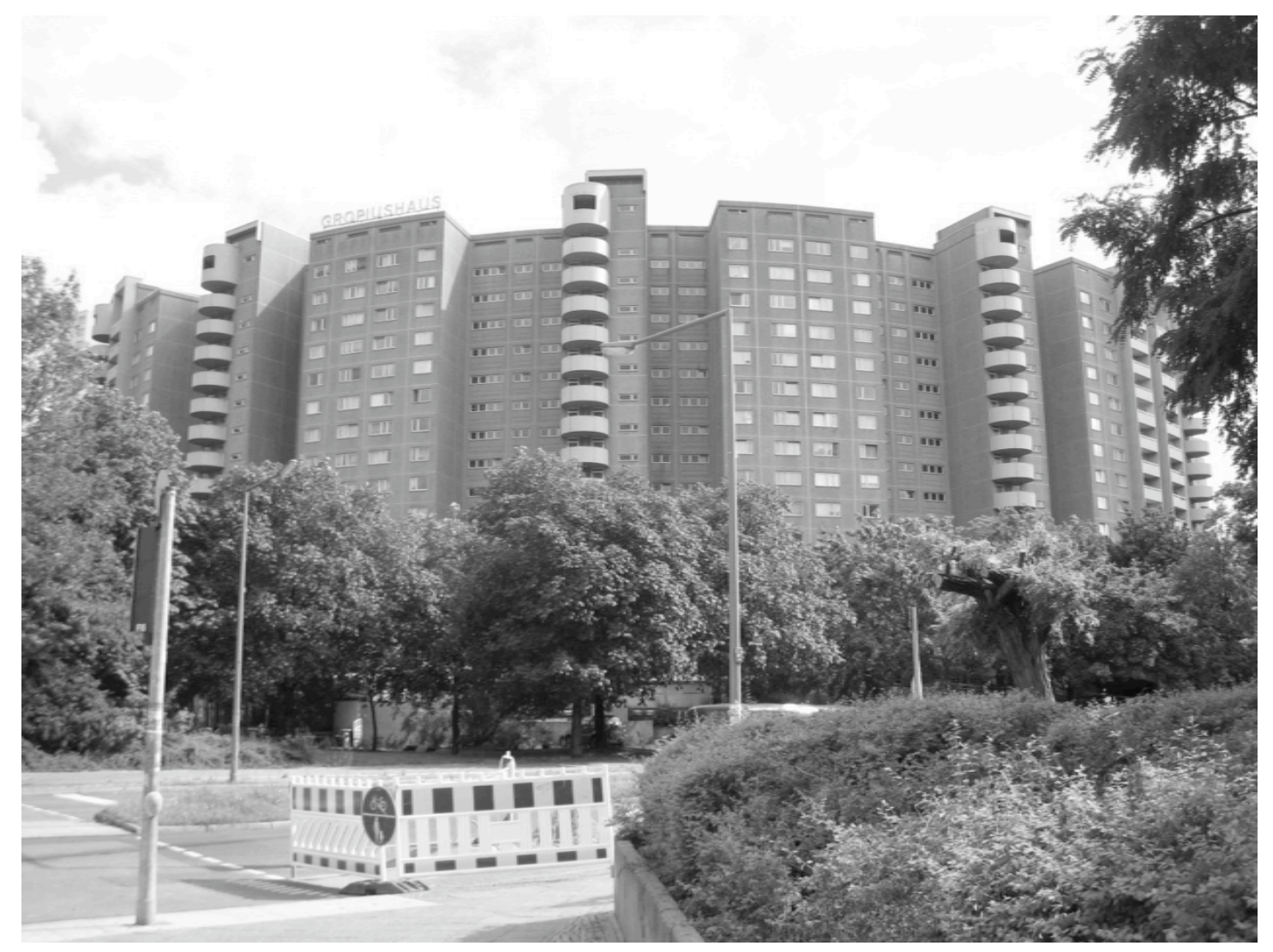

(C) Sabina Uffer

The aim of these large-scale housing estates was to overcome the schematic row developments of the Nineteen Twenties, Thirties and Fifties. Different high-rise developments constituted the area of these large-scale housing estates. While the design of the high-rise developments varied, they mostly had more than ten floors. Also, they were constructed with prefabricated slabs (Hanauske 1999: 105). Knorr-Siedow and Droste (2005: 16) characterise these estates as "distinctly different built entities, assessed as being a unitary type of an urban entity". As with the state subsidised housing in earlier years, the housing was built according to the latest standards. Because of state subsidies, the government determined allocation and rent ceilings. The post-war high-rise developments were predominantly inhabited by the German middle class, young couples, small families and some pensioners (Häußermann and Kapphan 2002: 82). Migrants and students remained in the old block developments of the inner city (see section 4.1.1 above).

In West Berlin, the construction of high-rise buildings was halted from 1974 onwards. This change in housing construction was not only induced by protests against the demolition of housing in the inner city; it was also connected to the starting decline of socially financed housing construction for the masses (Bodenschatz 1999: 231; see 
also section 7.1). The national state level had already been reducing its intervention in the provision of housing from the 1950s onwards. The 1980s however, marked a historical moment with a dramatic decrease in the provision of new state-aided housing.

The slower growth rate of West Germany's economy coupled with high inflation that was hard to tackle, but also an increasing over-supply of housing, led to the retreat of the national state from the provision of housing. Already under a socialist party government, but even more so under a more right wing oriented government, cuts in social welfare, and therefore housing provision became the main priority. Housing specific reasons also contributed to this re-thinking. There was a fading trust in stateowned housing companies and a belief that private housing companies would do a more cost-efficient job (see also chapter 5). At the same time, there was a growing concern that state-subsidised social housing was not targeting those who needed it the most because of the continuing occupancy by better off tenants (see also section 7.1). Another critique of the existing subsidies system was the fact that the rent levels in new social housing were higher than in the old housing stock (Harloe 1995: 460 et seq.; see also section 7.1).

The reduced intervention of the national state can be distinguished by two major transformations. First, the national state continuously decreased the volume of supplyside subsidies for housing construction (Kuhn 1999: 119). Housing allowances increasingly became the central instrument of the federal government's housing policy. Second, there was a shift from subsidising (social) rental housing towards the promotion of home ownership through tax-subsidies. ${ }^{70}$ With this transformation, West Berlin's housing provision construction fell into a crisis. The expectation of everincreasing economic growth was shattered. Instead, construction costs and interest rates exploded due to high land prices and an uncertain political future (Kuhn 1999: 119 et seq.). As mentioned, a reduction of the housing output from 1974 onwards was the consequence.

While West Berlin's housing construction began to decline starting in the 1970s, housing construction in East Berlin started to take off. It stood by the promise to solve the housing problem until the 1990s. Within twenty years, each family had to be accommodated within a housing unit that included heating (Bodenschatz 1999: 232).

\footnotetext{
${ }^{70}$ In 2006, based on the federal state reform (Föderalismusreform), the national government completely devolved the regulatory and financial responsibilities for the construction of supply-side subsidised housing onto the regional governments (Länder) and to the communities (Deutscher Bundestag 2007). This means that the national state did not only provide the Länder and cities with increased governing capacity, but also withdrew from the financial responsibilities of the housing provision. The law states that the housing market is more and more differentiated between and within the cities and therefore the Länder and cities can better target the specific local needs on the respective market (Egner et al. 2004).
} 


\subsubsection{Large-scale High-rise Developments in East Berlin}

The GDR government tried to solve the housing problem with the construction of industrialised high-rise housing. Compared to West Berlin, East Berlin's high-rise buildings were first constructed in inner city areas, "on the ruins of the rest of the old city" (Bodenschatz 1999: 225, author's translation). Only from the mid-1970s onwards did East Berlin's approach to housing construction converge with West Berlin's.

Between 1975 and 1990, three neighbourhoods with 68,000 (Marzahn), 34,000 (Hohenschönhausen), and 40,000 (Hellersdorf) housing units respectively, were constructed (Häußermann and Kapphan 2002). Schools, kindergartens and shops were integrated in these housing complexes. The goal was to have these facilities as well as a public transport hub within walking distance (Hannemann 1996). State-run housing companies built these estates and allocation was entirely state-led. Rents were standardised and only slightly higher than rents in the old housing stock in the inner city ${ }^{71}$ (Kemper 1998). The housing was highly standardised, built with prefabricated slabs (see Photo 4.6). In terms of housing quality, it was regarded as a higher standard than the rest of the housing stock because it had central heating. Criticism arose, however, because of the small room sizes (Hannemann 1996).

Through the construction of housing developments on an even larger scale than in West Berlin, the government hoped to relocate the population from inner city areas into new housing with better standards. The aim was to annihilate social classes. Thus, the development of new 'housing complexes' was considered the opposite of capitalist segregated urban development (Hannemann 1996). While there was a high mixture in terms of social status, the allocation policy of the state fostered other forms of segregation: The government gave priority to young couples and families, and ignored non-conforming and elderly people (Häußermann and Kapphan 2002: 70 et seq.; Kemper 1998).

\footnotetext{
${ }^{71}$ Rent levels within the old housing stock of the inner city remained at the level of 1936.
} 
Photo 4.6: Bird's Eye View of Prefabricated High-rise Developments in East Berlin (here, Marzahn, Marzahn-Hellersdorf)

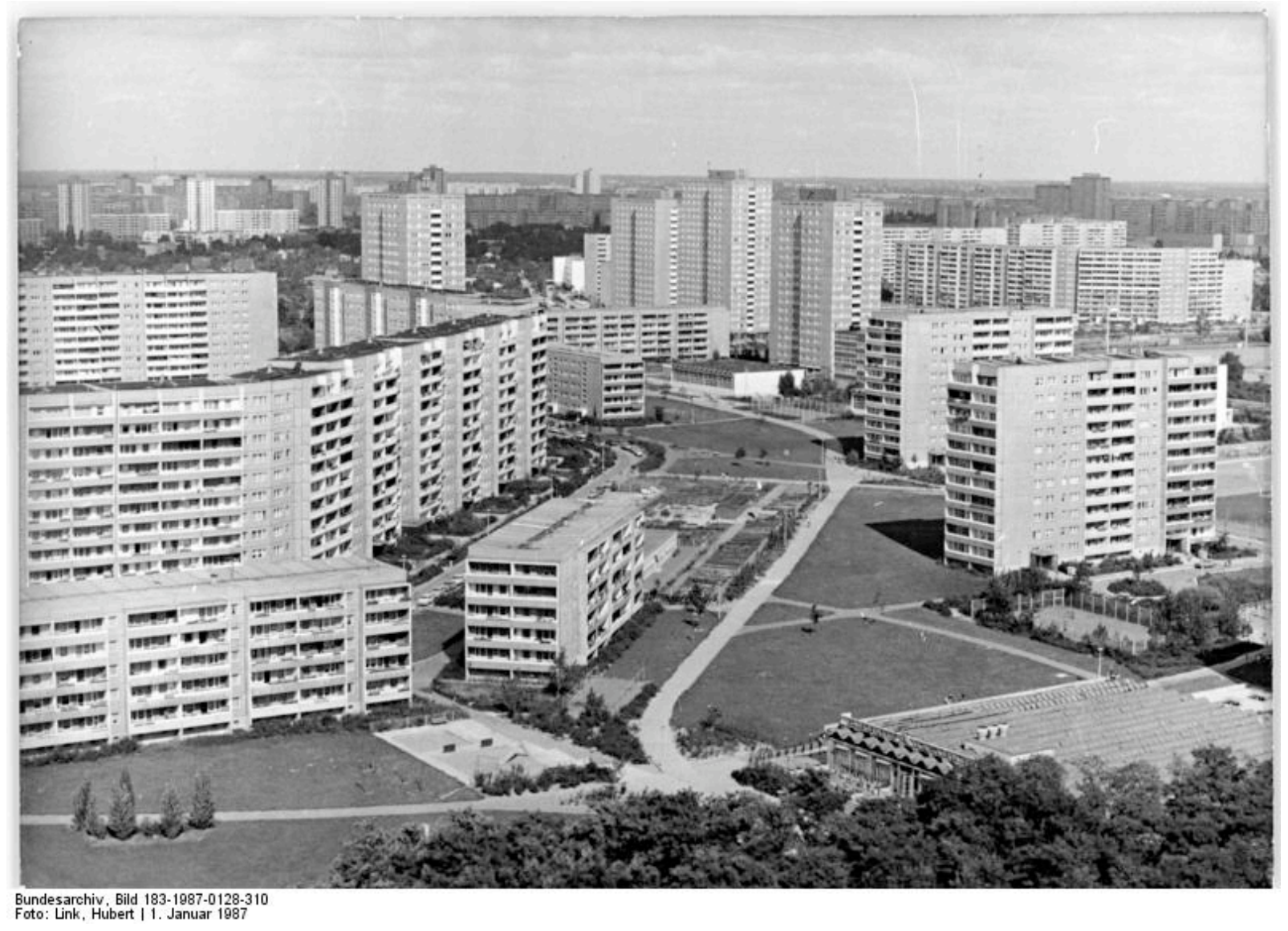

Source: Deutsches Bundesarchiv (German Federal Archive) ${ }^{72}$

The analysis of the post-war high-rise developments shows that the mode of housing provision in East and West Berlin did no longer significantly differ, at least with regards to the construction of new housing. Both cities solved the housing problem in the post-war era with the construction of state-directed large-scale housing estates in the outskirts even though the dimensions in the East were considerably larger.

While the attraction of these high-rise developments in West Berlin already began to fade since the 1980s, the prefabricated high-rises in the East quickly came under attack after reunification for their monotonous structure. Moreover, criticised for their peripheral location, the high-rise structures and the lack of social infrastructure, have increasingly been neglected. In East and West Berlin, the high-rise estates increas-

\footnotetext{
${ }^{72}$ Picture Number 183-1987-0128-310. Photo: Link, Hubert, 01.01.1987. Licenced under Creative Commons (http://creativecommons.org/licenses/by-sa/3.0/de/deed.en [accessed 29.03.2011]).
} 
ingly fought against a poor reputation. How do regulation, production, and consumption relations play out in this type of housing?

\subsection{Summary Illustrations of the Different Housing Types}

Having explored the historical development of the different types of housing, this section provides a spatial overview of the current housing provision in Berlin, still largely dominated by the three types of housing analysed in this chapter. Looking closer at Map 4.1 (see introduction of the chapter), it becomes apparent how the three types are spatially distributed within the city and shows the relatively clustered distribution of the late $19^{\text {th }}$-century block developments and the post-war high-rise buildings in comparison to the scattered distribution of the Twenties, Thirties, and Fifties row developments. The late $19^{\text {th }}$-century block developments mentioned in 4.1 are located in a "Wilhelminian"-belt around the urban core, which constitute the inner city districts in today's urban structure.

The Nineteen Twenties, Thirties, Fifties row developments are distributed all over Berlin, representing the earlier Twenties and Thirties developments within the inner city areas which were all connected to the city rail and subway network. The distribution of these row developments, however, also reflects the construction of the Fifties row developments, which were predominantly built at the periphery of the urban centre in West Berlin; and closer located to the urban core in East Berlin.

The post-war high-rise developments are clearly concentrated at the edge of the city. The large-scale developments are especially striking in the eastern part of the city, where the dimension of the construction of high-rise developments exceeds the ones in the West by far. In the western part of the city, the three large-scale housing estates with post-war high-rise buildings are however also apparent in the South, the North, and the West of the city. The small-scattered high-rise buildings in the inner city areas represent mostly newer developments from the 1990s onwards.

Figure 4.1 below shows the distribution of the housing types within the different administrative districts of Berlin in terms of area coverage (hectares). As in Map 4.1, Figure 4.1 also ignores the density of housing types, showing the land area, not the number of dwellings. It therefore needs to be taken into account that while low buildings with yards have a density of between 30 and 50 residents per hectare, post-war high-rise developments feature a density of between 220 to 290 residents per hectare. Late $19^{\text {th }}$-century block developments even have a density of between 280 and 490 
residents per hectare, depending on how much of the rear and side wings still exist within the block. ${ }^{73}$

Figure 4.1: Distribution of the Housing Types Among Berlin's Districts (in \% of ha)

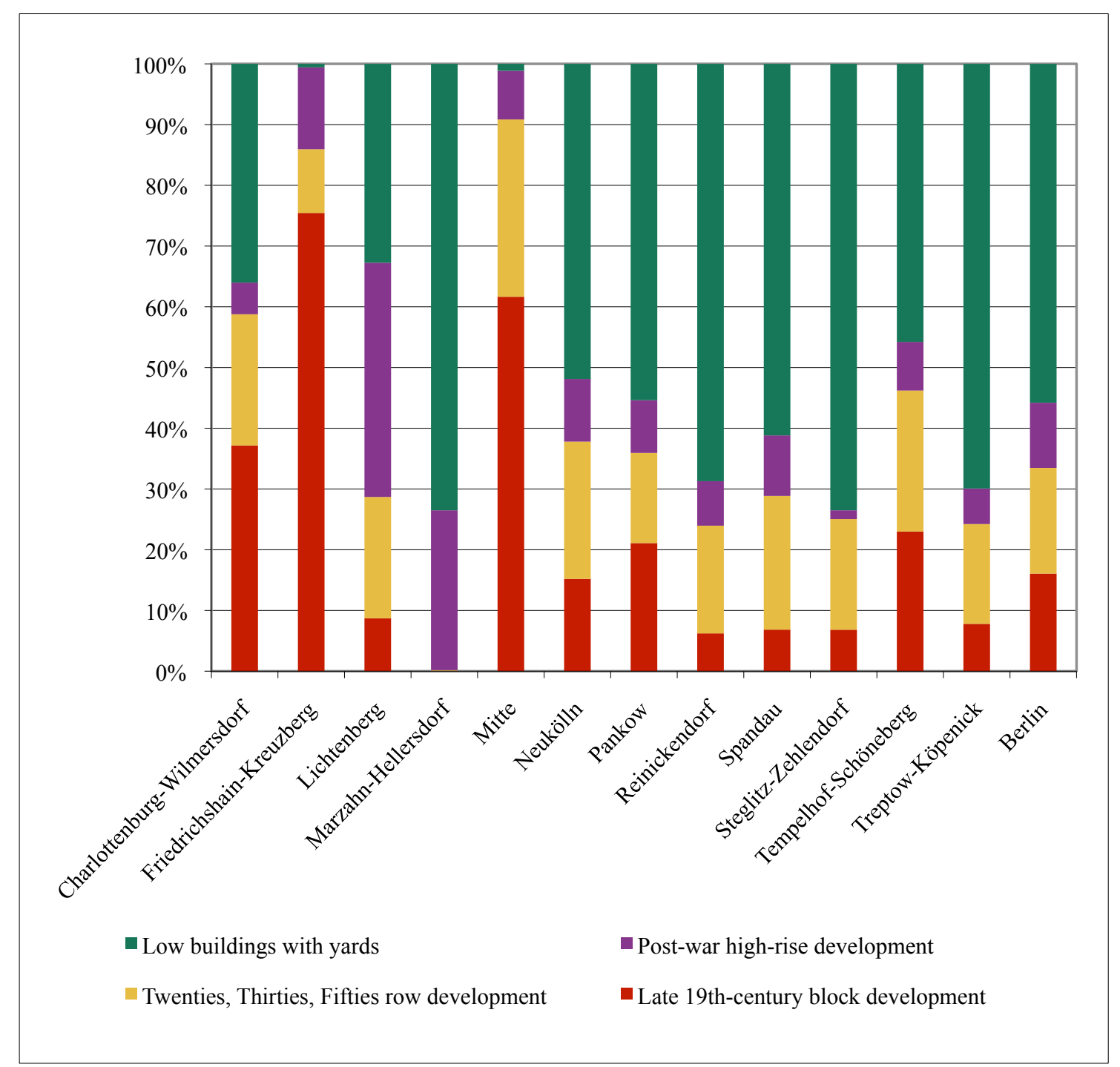

Source: Berlin Digital Environmental Atlas 06.07/08 Urban Structure (Edition 2008), Senate Department for Urban Development

Figure 4.1 nevertheless portrays the dominant building type within each district, revealing the specific housing structure within each administrative boundary. The inner city districts of Charlottenburg-Wilmersdorf, Friedrichshain-Kreuzberg, and Mitte have predominantly late $19^{\text {th }}$-century block developments. Again, the Nineteen Twenties, Thirties, and Fifties row developments are relatively evenly distributed. Post-war high-rise developments make up only a small percentage of the whole housing struc-

\footnotetext{
${ }^{73}$ See Senatsverwaltung für Stadtentwicklung (2010a) for a detailed table of the different levels of density within each housing type.
} 
ture in the districts. This housing type is relatively prominent in the outer districts of Lichtenberg and Marzahn-Hellersdorf, reflecting the large-scale construction in East Berlin. Due to the relative high density of these post-war high-rise developments, they take on an even more important role within these districts than reflected in Figure 4.1.

\section{Conclusion}

Arguing that the historical development of Berlin's mode of housing provision creates particular conditions for how regulation, production, and consumption relations played out in the past decade, this chapter established the spatial, institutional, physical, and social characteristics that continue to influence Berlin's current mode of housing provision along three different housing types.

First, the $19^{\text {th }}$-century block developments were built within an urban belt around the historical core of the city. West Berlin's block developments have undergone a process of sensitive urban renewal since the 1970s. In the mid-1990s, they were characterised by moderate rent levels and a social structure of immigrants, young, and elderly people living there. East Berlin's $19^{\text {th }}$-century block developments, in contrast, were decaying and rents were at pre-war levels. A considerable number of apartments were vacant. Other apartments were occupied by intellectuals and artists, as well as elderly people. Second, the Nineteen Twenties, Thirties, and Fifties row developments were built within the urban centre demarcated by the railway line and at West Berlin's periphery. In the mid-1990s, most of these apartments were below modern housing standards and in need of renovation. While the Twenties and Thirties row developments were centrally located and became acclaimed for their architectural style, the row developments built during the Fifties and later were at the urban fringe and criticised for their monotonous and small structure. Third, the post-war high-rise developments were constructed at a large-scale in the periphery. After reunification, the post-war high-rise developments in East and West Berlin got a poor reputation. They were criticised for their mass-produced character, for their monotony, and for their prefabricated structure. In the mid-1990s, these post-war high-rise developments were increasingly falling into decay.

The historical analysis of the three housing types also shows the institutional development of Berlin's mode of housing provision and its particularities, especially with regards to the high volume of social rented housing, which marked Berlin's housing provision. The following quote summarises the particularity of Berlin's mode of housing provision.

"Berlin was not only a tenement city, Berlin was the city of social housing construction par excellence, on this side as well as the other side of the Wall. The housing 
provision was therefore a field for experimenting with new urban planning visions of the welfare state. In both cities of Berlin, rent was subsidised to a degree that is no longer imaginable. This was due to the particular view on housing. Housing should not be a good, but a service, which needs to do justice to a basic needs of the human being. As such, housing had to adhere to a minimal standard, which was not exactly moderate. The non-profit housing industry in West Berlin and the communal housing provision in East Berlin were a significant part of this development. [...] With such a housing policy, a relatively low socio-spatial differentiation has been achieved, in East and West Berlin. The object of a socially even city became reality within certain limits" (Bodenschatz 1999: 237; author's translation).

This quote stresses the socio-spatial evenness of Berlin's housing provision. Due to the state-directed and standardised housing, the social segregation of Berlin's tenants was relatively low. However, the analysis of the different types of housing also shows that the quality of housing varies significantly with regards to its spatial, institutional, physical, and social legacy. There were thus differentiations not suggested in the quote above. This historically evolved unevenness has implications for the current mode of housing provision which is analysed in the following chapters.

With the economic and demographic decline from the mid-1990s onwards, the described particularities started to vanish. The reunified government increasingly struggled with a lack of finances while Berlin's housing market suffered from an oversupply. This led to dramatic changes in the city's mode of housing provision. Immediately after reunification there was a boom in housing construction (see chapter 1) that was triggered by special national subsidies and tax incentives for housing renovations and construction in East Germany. Experts and government officials first estimated that 800,000 new apartments would be needed. However, these growth numbers soon turned out to be illusionary.

In Berlin, most of the new housing construction happened between 1994 and 1998, a time when the population was already in decline. The construction was predominantly based on compact structures, with mixed height buildings which often evoked the resemblance with garden cities. These housing estates were mainly constructed at the urban fringe. The construction boom coupled with a declining population ${ }^{74}$ created a housing surplus for the first time in Berlin's urban development during the Twentieth century (Häußermann and Kapphan 2002: 100). As a consequence, a lot of housing units were vacant (see chapter 1), especially those with substandard conditions and in need of renovation. The transformation of Berlin's mode of housing provision (see

\footnotetext{
${ }^{74}$ Between 1990 and 1998, the housing stock grew 6.4 percent, while the population decline was 2 percent (Häußermann and Kapphan 2002: 100)
} 
chapters 5-7) from the end of the 1990s onwards took place under the premises of a relatively depressed housing market.

The analysis of this chapter thus raises two types of questions.

- How has the mode of housing provision with regards to regulation, production, and consumption changed in the last decade?

- How do the spatial, institutional, physical, and social differences of housing play out under the particular mode of housing provision?

Having established the historical legacy of Berlin's mode of housing provision, the following chapters turn to an investigation of how the particular mode of housing provision observed in the decade between 1999 and 2009 generated processes of uneven development. The analysis is carried out along three identified processes of reorganisation; the privatisation of state-owned housing and the entrance of institutional investment (chapter 5); the reformation of state-owned housing companies (chapter 6); and the abandonment of supply-side subsidies for housing (chapter 7). In order to understand the uneven processes that these transformation processes generated, the regulation, production, and consumption mechanisms of different types of housing providers are explored. 


\section{Privatisation of State-owned Housing and Institutional Investors}

The aim of the following chapters is to find empirical grounded explanations for why a particular mode of social regulation for housing provision creates processes of uneven development. Exploring the regulatory changes of Berlin's mode of housing provision towards a more entrepreneurial, meaning a more precisely market-oriented form (see chapter 2), three processes of reorganisation have been identified: The privatisation of state-owned housing; the reformation of state-owned housing companies; and the abandonment of state subsidies for construction and renovation of housing. Uneven development is either enabled or constrained through such regulatory processes. It is therefore necessary to understand the specific mechanisms these regulatory changes create under the given circumstances.

In order to understand the uneven development that the three identified processes of reorganisation created, it is essential to analyse its impact on the production mechanisms of the provision of housing structure defined in the conceptual model (see section 3.2). Production mechanisms contingently emerge through the different types of investors and housing companies that are active on Berlin's housing market. Through the privatisation of state-owned housing (this chapter) and the reformation of the remaining state-owned housing (chapter 6), the state enabled a diversification of housing providers. The guiding question for the next two chapters therefore is: How do the different providers contingently emerge under the specific market conditions through their finance, investment, management, and exchange strategies?

This chapter analyses the first transformation process towards a more entrepreneurial housing provision, namely the privatisation of state-owned housing. The aims of this chapter are fourfold: First, to understand how the specific regulatory conditions of privatisation enabled a diversification of housing providers, promoting the entrance of institutional investment (5.1); second, how global financial market mechanisms facilitated institutional investment (5.2); third, how local housing market conditions shaped profit expectations (5.3); and finally, how institutional investors who newly entered Berlin's housing market re-shaped the provision of housing structure through their contingently emerging mechanisms (5.4). 


\subsection{Privatisation Encouraged Institutional Investors to Enter Berlin's Housing Market}

Housing in Berlin was traditionally ${ }^{75}$ provided by either small private landlords or by non-profit housing companies that worked under the principle of the 'common public interest' (Gemeinnützigkeit). These companies were owned by churches, unionised companies, housing co-operatives, and in large part by the state (see also chapter 6). Berlin's state-owned housing companies predominantly owned housing estates built in the 1920s and 1930s, and from the 1950s onwards. The state-owned housing companies however also acquired some late $19^{\text {th }}$-century block developments in order to renovate them. After reunification, the housing stock built under the GDR regime was passed into the ownership of newly created state-owned housing companies, rapidly increasing the state-owned housing stock. In 1991, after reunification, Berlin owned a total of 19 housing companies, and through them 28 percent of Berlin's 1.72 million housing units (Senatsverwaltung für Stadtentwicklung und Investitionsbank Berlin 2002: 26).

Starting in 1995, Berlin's government began to privatise the state-owned housing stock. ${ }^{76}$ Berlin's government instructed the state-owned housing companies to sell 15 percent of its stock preferably to its tenants (Senatsverwaltung für Stadtentwicklung und Investitionsbank Berlin 2002: 36).$^{77}$ The structure of the sell off was quite different in East and West Berlin. While the aim to sell off 15 percent of the state-owned housing was practically achieved in the East by the end of 2000, only 5.4 percent could be privatised in the West during the same period. However, in the West, most apartments were sold to tenants and tenant associations ( 75 percent of units sold) whereas in the East, 80 percent of units sold were bought by investors (Senatsverwaltung für Stadtentwicklung und Investitionsbank Berlin 2002: 37). The privatisation process accelerated between 1998 and 2007 when the government sold two of its housing companies owning approximately 40,000 and 60,000 units respectively. In addition to facing difficulties in increasing the rate of owner-occupiers, state-owned housing companies sold entire housing estates en bloc.

\footnotetext{
${ }^{75}$ If not mentioned explicitly, the traditional mode of housing provision refers to the regulatory context of West Berlin. After reunification, East Berlin's housing provision was transformed into the social market economy of West Berlin under the Unification Treaty. For a more detailed account of the integration of East Germany's housing provision, see Steinmetz (2003) or Kofner (2004: 193-210).

${ }^{76}$ This process was enabled through the national government's deregulation of non-profit housing companies working under the principle of the common public interest (see section 6.1).

${ }^{77}$ In the eastern part of the city, the policy to sell 15 percent of Berlin's state-owned housing stock was based on the national law for help on past debts (Altschuldenhilfegesetz) (Bundesministerium der Justiz 1993). In the western part of Berlin, the policy was based on a Senate decision (Senatsbeschluss vom 10. Juli 1994, Senatsverwaltung für Stadtentwicklung und Investitionsbank Berlin (2002: 36)). As much as possible, these housing units were supposed to be sold to tenants, tenant associations and cooperatives.
} 
The en bloc privatisation starkly contrasts with privatisation processes in other Western European countries such as the right-to-buy policy in the UK (Murie 1976), or the promotion of home ownership in the Netherlands (Aalbers 2004). It also contrasts with privatisation processes of countries in the former Soviet bloc (Pickvance 1994; Struyk 1996a, 1996b). The privatisation process in Berlin, while similar in name, was quite different in process and scale to these other schemes. This was due to the difficulties of increasing owner-occupation (see section 5.3.3), but also due to the aims of privatisation. In order to account for these differences, it is thus not sufficient to look only at the outcomes of privatisation. This thesis argues that it is necessary to explore more closely the mechanisms and contingencies which generate these differences. This chapter therefore addresses the particularities of Berlin's privatisation process, interpreting the contingent regulation, production, and consumption mechanisms of the conceptual model established (see section 3.2).

Aiming to improve the government's budget created a process of en bloc privatisation

According to the respondents interviewed, the government's aim of the privatisation process was twofold. First, it aimed to improve its budgetary situation through selling the entire shares of two housing companies. Furthermore, the government anticipated that the selling of housing estates would help to reduce the remaining state-owned housing companies' debt loads, and therefore indirectly also the state's budget. The head of public relations of a private housing company summarised the two aspects of the privatisation process:

"The privatisation has to be viewed from the perspective to relax the budget and it took place at a time when the government absolutely needed cash. We were not the only company that was sold; also other state-owned companies and other housing estates were sold. That means privatisation contributed to the strengthening of the government's budget. From an economic standpoint, privatisation has definitely unleashed impulses for the modernisation of the housing economy and the investment in the housing stock." (Head of public relations of a private housing company, ID 23$)^{78}$

The government's second aim for privatisation, according to the respondents, was to trigger investment into the housing stock that the state-owned housing companies could no longer execute. In East and West Berlin, the housing estates built before and after the Second World War were mostly in need of renovation and modernisation. The state-owned housing companies however struggled with high debts. ${ }^{79}$ The priva-

\footnotetext{
${ }^{78}$ The interviews were in German. I therefore translated all quotes.

${ }^{79}$ In 2000 , the seven state-owned housing companies had an annual debt of 347.23 million Euros (Senatsverwaltung für Finanzen 2004a).
} 
tisation created hope that investors would have the financial resources to modernise the housing stock. An urban planner and member of a district parliament stressed the necessity for renovation and the incapability of state-owned housing companies:

"The prospects of privatisation are of course that the housing stock gets renovated. There are still bigger housing estates that were built before or shortly after the war and that have a standard that is today completely outdated in regards to sanitary or heating systems. And state-owned housing companies were apparently overstrained to invest in these housing units." (Urban planner, member of a district parliament and head of the district's urban planning commission, ID 15)

The state's financial situation was key to the privatisation of its housing stock. The privatisation process was however also facilitated through the depressed housing market, which meant that housing had taken a back seat among political parties. ${ }^{80}$

"Previously, each political party in Berlin gained popularity through their housing strategy because of the immense housing shortage everywhere. This was no longer the case in the mid-1990s." (Managing director of a research institute for housing and urban development, ID 2)

The government chose to improve its budget and to restore the financial capacities of state-owned housing companies through a novel strategy of an en bloc privatisation where entire state-owned housing companies or housing estates were sold off. This process is in line with a more entrepreneurial housing provision (see chapter 2), trying to attract private investment that takes over services that the state previously provided. The privatisation principle itself however, does not explain processes of socio-spatial inequality. It is necessary to understand the specific mechanisms by which the privatisation of state-owned housing has taken place to understand the outcome, the conditions it created. This section therefore analyses the way the en bloc privatisation process played out in practice. In particular, the section highlights how it opened up the market for a new and specific type of investor.

\section{Selling en bloc generated interest from institutional investors}

As noted, in contrast to the privatisation processes where home ownership is promoted (see, for example, Murie 1976; Struyk 1996b), Berlin's privatisation happened en bloc. This affected who was willing and able to buy the housing stock en bloc. The en bloc privatisation process of the housing estates and housing companies spawned

\footnotetext{
${ }^{80}$ There was a struggle between the Senate Department for Finance (at the time in the hands of the right-wing CDU party) and the Senate Department for Urban Development (in the hands of the social SPD party). However, the SPD party congress in 1997 decided to go along with the privatisation proposal of the Senate Department for Finance to disencumber the state of Berlin and the state-owned housing companies (Oellerich 2011).
} 
institutional investors' interest as a result of two mechanisms: First, buying an entire housing company or an entire estate, institutional investors negotiated discount prices for the individual housing units (see also Holm 2010). Several informants expressed their concern that the housing stock was sold too cheaply:

"If one looks at the price the state got for a single apartment, then one realises that it was apples and eggs that were sold. The selling price [for the housing company or the estate] sounds high; however when you divide it per apartment, you get an average price of 30,000 Euros per apartment. This is not a very exciting amount." (Urban planner, member of a district parliament and head of the district's urban planning commission, ID 15, see also ID 11)

The second mechanism as to why the government's en bloc selling appealed to institutional investors was the opportunity to increase management efficiency through economies of scale. Institutional investors do not have an interest in buying a single apartment, because it would not be worth the effort. Being able to buy a housing estate, institutional investors saw the possibility to efficiently modernise and manage the housing units. The head of public relations of a privatised housing company explained this strategy:

"Buying compact structures, efficiency models arise in regards to the modernisation, maintenance, and management of the housing. This means, it is easier to administer a compact housing structure, starting with addressing the tenants, the supply of support personnel for the maintenance and the complaints management, the exchange of tenants and so on, also with regards to energy provision, and garbage removal. When you have compact structures, you can generate high volume business where prices decrease and where technical equipment is cheaper." (Head of public relations of a private housing company, ID 23)

The en bloc selling however also favoured institutional investors as purchasers because of their financial capacity. The fact that the government wanted to make the highest profit possible reinforced the institutional investors' position vis-à-vis other possible purchasers. Thus, the government created a new market for investors.

\section{Aiming for the highest price favoured institutional investors as purchasers}

The emergent process that can be identified is that in both cases the government's sale of the housing companies and the state-owned housing companies' sale of the housing estates, the companies and the estates were sold to the highest bidder due to the focus on the financial benefit of privatisation. As a consequence, institutional investors were unintentionally favoured since they have the necessary equity to make en bloc purchases and bid high in comparison to housing co-operatives or other forms of ownership with lower access to capital. 
The government however also largely ignored alternative forms of privatisation such as the possibility of forming housing co-operatives. In one case where tenants founded a co-operative to buy the estate themselves, was the state-owned housing company forced to give in. ${ }^{81}$ This happened however only because of a bottom-up initiative and public protests. The government did not promote this form of privatisation. Moreover, the state did not question the bidder's strategy in the privatisation process. This was partly due to the constraint of achieving the highest return possible and partly due to a lack of understanding by the government and state-owned housing companies how particular types of investment funds would act in Berlin's housing market. The government thus was conscious that their selling strategy would attract institutional investors above all. However, it was not aware of the consequences particular institutional investors' strategies would have on Berlin's housing market.

The government therefore, did not differentiate between short-term and long-term investors (which is common in the private sector, see section 5.4). As a consequence, the government's unintended default favoured one type of investor. Short-term investors, which follow a strategy of trading housing and not necessarily investing in it, often overrode long-term investors because they did not have to take into account possible renovation costs. Long-term investors in contrast needed to integrate renovation costs into their bid. An informant confirmed the government's ignorance:

"Often financial and private investors are lumped together and it is not analysed what strategy they exactly follow. I always plead for a careful analysis of the investor's concept and there is nothing to say against long-term investors because they have to treat the housing stock economically and socially as reasonably as the state-owned housing companies have to. However, if you sell to a financial investor with a short-term asset strategy, then you don't need to be surprised about their behaviour. However, politicians apparently don't have enough knowledge or interest to differentiate investors. Therefore, the decision to sell to an investor is often based on the principal of the highest bid. And in the past, financial investors that could bid the highest prices were the ones with short-term interests while the long-term investors consider the need for investment and calculate modernisation costs. Short-term investors are not interested in that." (Former project manager for the development of a housing estate employed by an asset management company, ID 13)

A careful investigation of the bidder's strategy is however also relatively difficult due to external factors such as financial market mechanisms. The investor dynamically adapts a strategy based on the specific conditions of the financial and the housing

\footnotetext{
${ }^{81}$ There was a case in 1999 where tenants of an estate (Bremerhöhe) got together and founded a cooperative. Supported by political protests, it prevented the sell off to a financial investor and ended up buying the housing estate.
} 
market (see also section 5.4.1). The manager of a state-owned housing company that sold an estate explained the difficulties they had in assessing the bidder's strategy:

"First, there is the observation of which strategy they follow. Second, which strategy can they follow [in the actual market-situation] and third, which strategy are they pretending to follow. In this case, the investor pretended to be a long-term investor and it was difficult to confirm. Because it was a fund, it could have been possible. However, as it turned out later, the investor was apparently more of a short-term investor." (Managing director of a state-owned housing company, ID 28)

The analysis of the privatisation process shows that the state was rolling-back from the provision of housing, reducing the influence it could exercise on state-owned housing companies. The process however is complex and can take different forms due to the causal relations that triggered it. It is embedded in particular spatial and temporal contingencies, which need to be understood in order to reveal the specific mechanisms it generated. In Berlin, the government privatised two entire state-owned housing companies in order to decrease its debts and urged the remaining state-owned housing companies to sell 15 percent of their housing stock to consolidate their budgets. Due to financial pressure to sell within a short time period and difficulty selling to tenants the two state-owned housing companies and many housing estates were sold en bloc. The specific modality of privatising the housing stock en bloc to the highest bidder in effect favoured institutional investors. The entrance of institutional investors in Berlin's housing market was however also triggered by changes in global financial markets. Having established the specific way Berlin's government enabled the interest of institutional investors in the city's housing market, the next section turns towards an analysis of the global financial markets which facilitated institutional investment at the time.

\subsection{Global Financial Market Mechanisms Directed Institutional Investors Towards Real Estate}

The internationalisation of financial markets made capital more mobile (Dicken 2003; Held and McGrew 2003) creating opportunities for institutional investors to diversify their investment portfolio by investing in different sectors and different geographical markets. Three processes drove the internationalisation of financial markets. First, the development of new communication technologies such as advanced telecommunication systems dramatically decreased transaction costs for financial institutions. A wide range of data can be instantaneously analysed and investment decisions can be promptly made. Thus, "[c] apital is managed around the clock in globally integrated financial markets working in real time for the first time in history: billion dollars 
worth of transactions take place in seconds in the electronic circuits throughout the globe" (Castells 2000: 102).

Second, the deregulation of financial markets and the liberalisation of cross-border transactions enabled saving and investment from anywhere to anywhere (Castells 2000). Financial deregulation took place in most countries, starting in the US in the mid-1970s, but becoming more wide spread in the 1990s, moving to the 'Big Bang' in London in 1987, followed by France ('Little Bang' of 1987) and Germany (Dicken 2003). Technological advances made financial regulation especially difficult and created a global competition where governments became increasingly constrained to "maintain existing levels of social protection or welfare state programmes without undermining the competitive position of domestic business and deterring muchneeded foreign investment" (Held and McGrew 2002: 55). Financial institutions were able to move their activities to less regulated areas. This led governments to relax their domestic regulations in order to keep and attract new investment. A parallel process of multilaterally dismantling capital control and unilaterally relaxing regulations generated increasing international financial integration (Herring and Litan 1995; Linneman 2004).

The third process contributing to the internationalisation of financial markets was the invention of new financial products. Technological advances also fostered an innovation of financial products where financial attributes are repackaged to redistribute the risk of those investing. The desired investment product can be achieved through a multiplicity of arrangements and risk can be spread among the investors (Herring and Litan 1995; Linneman 2004). These financial products "recombine value around the world and across time" (Castells 2000: 104), often moving financial capital in a speculative way.

This development primarily benefitted investment banks that specialised in providing their clients access to the global financial market and offered "an entire package of services - a 'one-stop shop' - to customers" (Dicken 2003: 458). Thus, the international financial market is increasingly dominated "by a small number of highly capitalized securities and banking houses" that primarily invest institutional capital via diversified activities (Hirst and Thompson 2003: 345). Institutional investors such as pension funds, insurance companies, banks, and university endowments began to dominate the financial markets. These types of investors have large amounts of capital that need to be invested. Harrison and Bluestone (1990) call this "impatient capital" where pension funds and other institutional investors are expecting short-term results for their investment and are under pressure to earn "competitive risk-adjusted returns" 
(Herring and Litan 1995: 17). In order to boost returns and reduce the volatility of investment portfolios, institutional capital is diversified geographically and sectorally.

After the stock market crash in 2000, most central banks in developed countries drastically decreased interest rates, flooding "their economies with more financial liquidity, in order to prevent recessions" (Downs 2009: 8). In this financial environment, real estate increasingly became a target for financial investors for two main reasons: First, the profitability of real estate is "greatest when interest rates are low and money can be borrowed easily" (Downs 2009: 8) which was the case at the time. Second, because financial investors suffered "from excessive exposure to the volatile technology market" in the late 1990s (Falzon et al. 2003: 68), they increasingly turned towards the supposedly "safe harbour" of real estate (Winograd 2004: 200; see also Rottke 2004: 61). Institutional investors previously avoided real estate because it was less liquid than other assets such as stocks. Furthermore, institutional investors did not have the required knowledge of local property markets that they assumed they would need. This changed however with the stock market crash in 2000: "Owning real estate in some form seemed desirable both because it increased the diversity of portfolios and because although nearly all stocks were plunging in value and bonds were vulnerable to possible increases in inflation, real estate property values kept rising" (Downs 2009: 13). With investment in real estate, capital takes material form and becomes embedded in place and time, and is subject to institutional and regulatory control.

The en bloc privatisation in Berlin happened exactly at a time when institutional investors entered real estate markets, matching institutional investors' demand. ${ }^{82}$ The combination of the effects of local regulation and global accumulation strategies created the perfect storm. It was a mutual reinforcing mechanism. Berlin's mass selling strategy of state-owned housing offered institutional investors the advantageous investment opportunities they were seeking. In addition, global financial market mechanisms provided the required capital conditions necessary for real estate investments. The availability of cheap money and cheap housing were key factors for institutional investment. The process of privatisation was therefore accelerated by the global economic conditions at the time. The specific conditions of the local housing market however influenced the way institutional investors operated in Berlin's housing mar-

\footnotetext{
${ }^{82}$ The role of institutional investors in private rental housing has also been acknowledged in other countries. Ball (2007), for example, sees an increasing role for large-scale investors in private rented housing in the UK. However, the matching between demand and supply in Berlin was especially striking. Obstacles observed by Berry (2000) and Berry and Hall (2005) in Australia's rental market, such as high management costs due to a lack of intermediary structure between tenants and investors and poor market information, did not play a role in Berlin.
} 
ket. The next section therefore analyses the local housing market conditions that institutional investors encountered and the profit expectations this fostered.

\subsection{Institutional Investors' Profit Speculation and the Reality of the Local and Global Market Conditions}

In Berlin's housing market, institutional investment has primarily taken place via real estate private equity funds. ${ }^{83}$ The hybrid of real estate and private equity presents a good investment opportunity since it combines the relative stability of real estate with the "opportunity for high degrees of value creation" in private equity (Falzon et al. 2003: 78). ${ }^{84}$ According to Rottke (2004: 28 ) real estate private equity is a form of investment through which equity is provided based on non-regulated funds.

Figure 5.1 shows the operational structure of a real estate private equity fund. Investment banks, investment houses or other real estate players (see Linneman 2004: 159) create and manage funds by collecting money from institutional investors. ${ }^{85}$ Investment banks often also contribute equity to the fund in order to stimulate the confidence of institutional investors (Rottke 2004: 88). With credit capital from a bank, funds then invest directly in real estate like housing estates or indirectly through shareholding of housing companies. ${ }^{86}$ Often fund managements also collaborate via a joint venture with a local company, which has the valuable expertise of the local market.

\footnotetext{
${ }^{83}$ A deterioration of the German national regulatory situation for traditional institutions providing credit in the real estate market contributed to the increasing popularity of real estate private equity funds. See Rottke (2004) for a detailed analysis of the regulatory changes within the financial market in Germany.

${ }^{84}$ The hybrid between real estate and private equity became an interesting investment vehicle for both sides. On the one hand, institutional real estate investors have been "seeking higher risk-adjusted returns" in an increasingly competitive environment. Private equity investors, on the other hand, were looking for an alternative because of the high volatility of other assets, in the technology market for example (Falzon et al. 2003: 68).

${ }^{85}$ Large institutional investors often also have their own fund managements.

${ }^{86}$ When not otherwise specified, housing companies that are referred to in this chapter are owned by real estate private equity funds.
} 
Figure 5.1: Operational Structure of a Real Estate Private Equity Fund

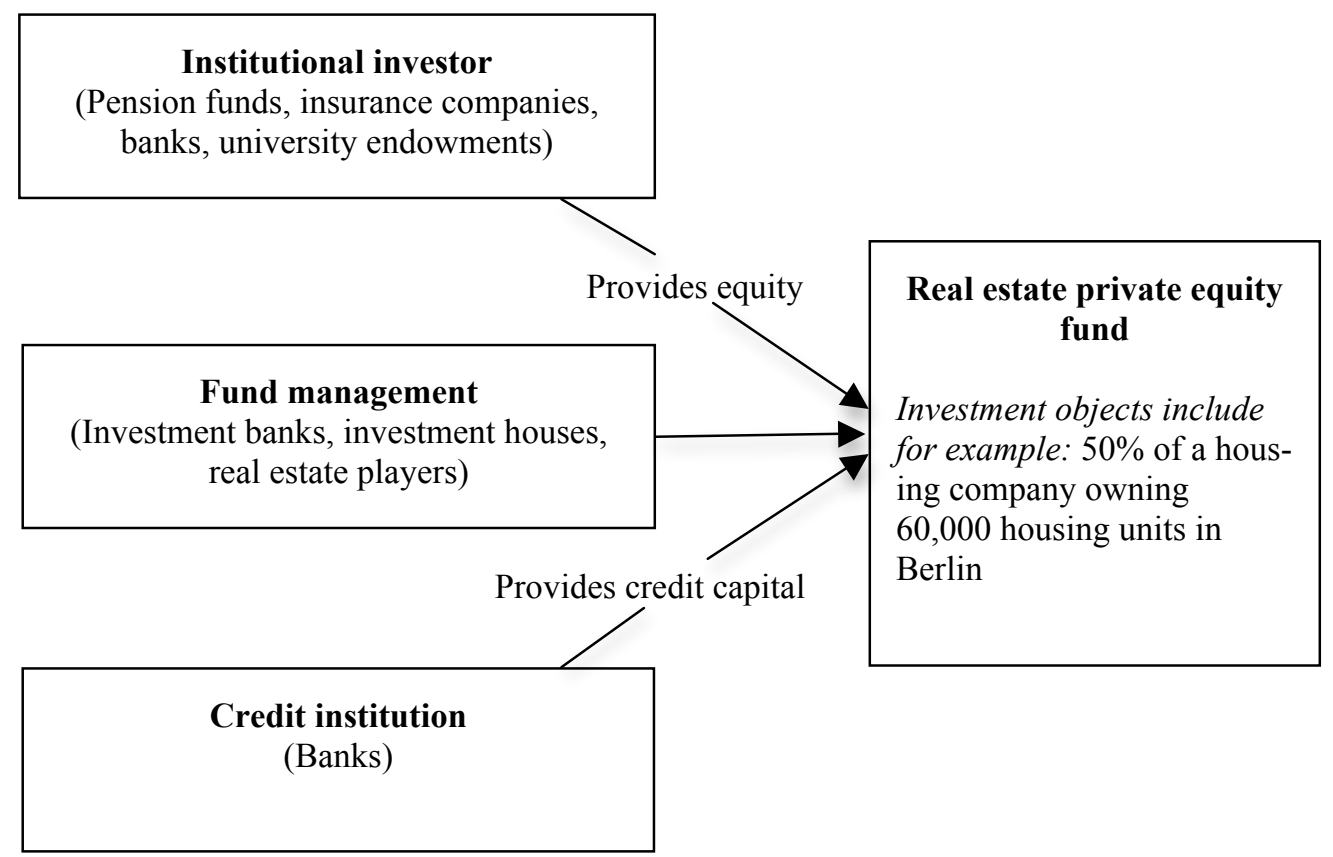

Source: my own illustration on the basis of Zingel (2006: 8).

Due to favourable market conditions in Berlin's housing market, real estate private equity funds were expected to make high returns. On the one hand, real estate private equity fund investors believed that capital gain could be achieved through returns from use (see section 5.3.1). On the other hand, they believed that capital gain could be achieved through rising prices independently from use (see section 5.3.2). The following sections explore the investors' expectations comparing them with the actual market conditions.

\subsubsection{Speculation on Capital Gain Based on Rising Demand for Use}

Capital gain achieved through the use of housing is measured based on the yield of a property which is defined as the profit on the capital investment of housing. ${ }^{87}$ If there is an expectation for upward rents, yields are increased. This is especially true when the property was acquired at a low price. A central strategy for investors therefore, is to enter the market at the right time. This means that the optimal entry point occurs when prices are lowest and are due to rise, using inequalities in the real estate market cycle (Rottke 2004). An investor explained this method of assessing the potential of a market based on the example of Berlin:

\footnotetext{
${ }^{87}$ It is usually calculated as the annual rent minus the costs divided through the price paid for the property.
} 
"We have a top-down approach. This means, we invest internationally and analyse in which country there is disequilibrium in the real estate market and which scenarios could come out of this. We are asking ourselves a) why are apartments in Berlin so cheap? b) how attractive is Berlin as a location? and c) in which time span is the disequilibrium going to be balanced out? Because in the long run, real estate markets are always growing. Thus, for example, in 2003 we saw an increase in offers on the housing market in Berlin, but a relatively limited demand. This means it is attractive to buy because it is cheap." (Principal of an investment firm, ID 7)

Investors speculated on Berlin as a rising housing market despite the general macroeconomic situation not being very favourable at the beginning of the 2000s; a stagnating economy including high unemployment rates and little purchasing power. ${ }^{88}$ This speculation on a rising market was due to several mechanisms: First, low rent levels combined with a relatively high fluctuation rate of 9.4 percent in 2003 (Senatsverwaltung für Stadtentwicklung 2005b) was considered interesting; it was an opportunity to increase rent levels through modernisation. Second, the extreme predominance of a rental market created hopes for the potential increase in owneroccupation through the re-selling of single housing units. And third, because there was no new construction, the expectation was that the supply could not keep up with the anticipated demand. The CEO of a private housing company summarised these points:

"The interest of investors stemmed from the fact that the quota for home ownership was low, that Germany is in general a fundamentally strong economy, and that there would be potential to increase the rent levels." (Chief financial officer of a private housing company, ID 12, see also ID 7)

The low prices and the lack of new construction would however not have raised the same interest if investors did not also have a perception that Berlin was gaining in popularity and growing by attracting new inhabitants (see chapter 1). Investors thus partly speculated on a rising demand for use. They also however, speculated on a rising demand for investment.

\subsubsection{Speculation on Capital Gain Based on Rising Demand for Investment}

While at the end of the $1990 \mathrm{~s}$, investment was still predominantly made by German investment firms, Berlin's housing market experienced a veritable hype from 2004 onwards when one of the world's leading investment firms entered the market and created a herd-like movement of international investment firms.

\footnotetext{
${ }^{88}$ See discussion on Berlin's urban development in chapter 1.
} 
"Once that internationally well-known investment firm was here, other investors followed and have shopped around in Berlin." (Chief financial officer of a private housing company, ID 12)

Figure 5.2 illustrates the increase in sold housing portfolios from 2004 onwards. It not only includes the selling from state-ownership to private ownership but also re-selling among private investors.

Figure 5.2: Sold Housing Units in Berlin 1999-2000

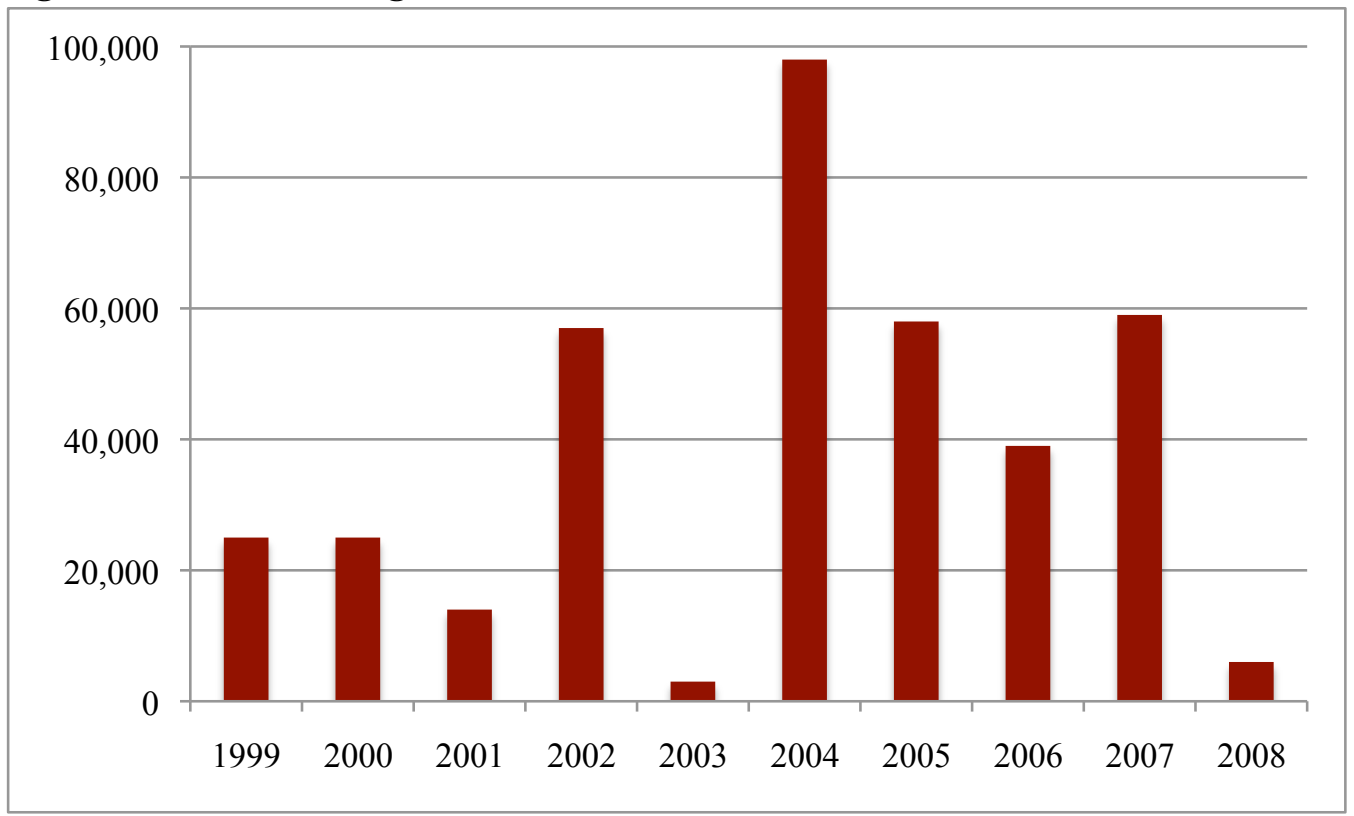

Note: Only big housing stocks of more than 800 housing units are considered.

Source: Bundesinstitut für Bau-, Stadt- und Raumforschung (BBSR) Datenbank Wohnungstransaktionen, Juli 2009

The investment hype fostered a self-reinforced speculation to make capital gains because the demand for buying real estate is higher than the offer. For these investors the demand for the use of housing did not play a significant role. More importantly, it was the availability of cheap credit capital that fostered the increase in price speculation. Specific housing market conditions such as vacancy rates were therefore mostly irrelevant. One investor interviewed admitted that he does not know much about Berlin's housing market (ID 7). The projected return was therefore simply a speculation on the increase of value due to an increasing demand for investment.

The real market conditions did however not match investors' expectations. Different forms of market failure abated speculation on the demand for use and investment. The expectation to make returns from use was tempered by Berlin's slowly growing economy. Moreover, the expectation to make returns from rising housing prices faced a severe drawback due to the financial crisis in 2008 and 2009, when credit capital became scarce. Due to these local and global market failures, investors could not make 
the expected return on investment. The following section explores how respondents perceived the actual situation of Berlin's housing market.

\subsubsection{Local and Global Market Failures}

An analysis of the market situation in Berlin shows that investors' expectations and needs to make a return on investment through higher rent levels and the transformation to owner-occupied housing were not realistic. In 2004, 17.7 percent of Berlin's population was still unemployed (Amt für Statistik Berlin-Brandenburg 2009a). The income of Berlin's population, with an average of 15,000 Euros per person per year, is significantly lower than in other German cities ${ }^{89}$ (Investitionsbank Berlin 2009). Moreover, income levels have not increased significantly over the last ten years. It was therefore difficult to achieve higher rent levels, especially in lower market segments. Furthermore, the transformation to owner-occupied housing is very slow because rent levels are still considerably lower compared to the costs of home ownership (Holm 2010). Several informants confirmed that it is hard work to increase the rate of homeowners, because owner-occupation is not very common in Berlin:

"The owner-occupied flat is still associated with a lot of disadvantages. There are more profitable investment possibilities than the owneroccupied flat. A rented flat also offers more flexibility, especially when the professional situation is more and more flexible. And when people want to have their own house, it is still the idea of a detached home, because you have your privacy and there is no need to negotiate with a neighbour you don't like." (Managing director of a research institute for housing and urban development, ID 2)

"We have a subsidiary company, which painfully operates the selling. [...] We sell now between 150 and 250 units per year, but we have to put huge efforts into it." (Managing director of a state-owned housing company, ID 28)

The lack of demand for owner-occupied housing and relatively low incomes are all signs that some investors overestimated the specific local conditions. A representative from the Senate Department of Urban Development confirmed that expectations were largely overrated:

"The yield expectations that stood in the foreground when buying the housing units in Berlin are not realisable. On the one hand, we have a relatively depressed market. On the other hand, Berlin is one of the cities with the lowest income levels. This means the leeway for rent increase is not very large if you do not want to overburden your tenant, which would lead to a higher vacancy rate. And housing companies

\footnotetext{
${ }^{89}$ Hamburg 24,000 Euros; Munich 22,000 Euros; German average 18,000 Euros (Investitionsbank Berlin 2009).
} 
normally try to prevent vacancies." (Employee of the Senate Department for Urban Development, ID 5)

Investors therefore had many difficulties achieving the expected return from use. This, however, played a less important role as long as credit capital was cheaply available, maintaining and creating a demand for investment in real estate (see also section 0 ). With the financial crisis of 2008, however, the returns from speculating on buying cheap and selling high were also slashed. Credit was no longer as cheap and easy available as in the boom years. This drastically lowered the demand for real estate investment. Figure 5.2 (see above) reflects the dramatic decrease in housing transactions. ${ }^{90}$ A financial officer admitted that the combination of local and global conditions made it hard to achieve the anticipated profit expectations:

"It shows now that the expectations to increase rent levels and converting dwellings into owner occupied housing is not feasible. Investors have increasing problems to refinance their investment because their business plan was too short sighted. While the prices haven't suffered yet, there are just no transactions anymore. The market does no longer exist." (Chief financial officer of a private housing company, ID 12, see also ID 9)

The actual property market of Berlin starkly contrasted with investors' speculation on rising demand for use and investment. Having entered Berlin's housing market, institutional investors had to deal with the specific form of local and global market failures.

Having analysed how and why institutional investors entered Berlin's housing market and what local and global market conditions they encountered, the chapter turns towards an analysis of the contingently emerging production mechanisms of the different real estate private equity funds used as investment vehicles. ${ }^{91}$ The strategies of the funds to deal with specific market conditions depended on their contingently emerging finance, investment, management, and exchange mechanisms.

\footnotetext{
${ }^{90}$ A report by the Senate Department for Urban Development equally confirms the impact of the financial crisis by showing that there were 19 percent less housing portfolio sales in 2008 compared to 2007 (Geschäftsstelle des Gutachterausschusses für Grundstückswerte in Berlin 2009).

${ }^{91}$ For simplicity, funds are regarded as agents in the following, even though it is the institutional investor that decides to invest in a particular fund and the fund manager who makes the strategic decisions.
} 


\subsection{Local and Global Market Failures Shaped the Strategies of Real Estate Private Equity Funds}

Thus far, the chapter analysed the specific way in which the privatisation process and the conditions of the global financial and the local housing markets created and shaped the entrance of institutional investors through real estate private equity funds ${ }^{92}$. In order to understand how the particular mode of housing provision that came into place with the privatisation of state-owned housing stock creates uneven development in Berlin, it is necessary to investigate the contingently emerging production mechanisms of this new owner structure and the changing relations this has on the consumption of housing.

The explanatory model in chapter 3 defines production mechanisms that we should expect to find in any empirical situation in terms of finance, investment, management, and exchange. Based on these categories, one might expect different emerging types of investment funds under the specific market conditions. The following questions guided the analysis:

- How do the production mechanisms of the different types of investment funds play out in practice under the local and global market failures?

- How do the production mechanisms of the different types of investment funds affect the consumption under the local and global market failures?

The remaining sections of the chapter turn towards an analysis of the contingently emerging types of real estate private equity funds and investigate how their specific mechanisms create processes of uneven development.

\subsubsection{Two Types of Real Estate Private Equity Funds}

The explicit investment funds' finance strategy was mostly kept a secret by my informants due to it being proprietary information. Specifically, the managers of large funds were not willing to reveal particular strategies (see also section 3.4.1). However, from the literature on institutional real estate investment, different strategic considerations of investment funds can be interfered. The following sections, therefore, draw on the existing literature (Linneman 2004; Rottke 2004; Brueggeman and Fisher 2008) to portray the different characteristics of investment funds and the accumulation strategies they pursue. Integrating this literature back into the empirical cases, the diver-

\footnotetext{
${ }^{92}$ In the remaining part of the chapter real estate private equity funds are referred to as investment funds in order to make it easier for reading.
} 
ging investment, management, and exchange strategies are then analysed, and the uneven mechanisms they created within Berlin's mode of housing provision are revealed.

During the time that a real estate private equity fund is active, ${ }^{93}$ there are many different strategies to achieve a return on the institutional investment and as such, several are often combined. ${ }^{94}$ A major criterion to distinguish between different investment strategies is the target return coupled with the degree of risk involved. The literature (Rottke 2004: 87; Falzon et al. 2003) on the real estate industry usually distinguishes three types of real estate private equity funds: core, value added, and opportunistic investment. Zingel's (2006: 7) analysis of real estate transactions points however to the fact that the core investment fund, which bears the least risk but also the lowest return, did not play a significant role in the context of Germany. The case studies analysed confirmed this assessment and this thesis therefore concentrates on the two other types: value added and opportunistic investments. This differentiation of institutional investment contrasts with the theoretical literature on the uneven development of regulation and accumulation (Harvey 2006), which seldom goes beyond a universal definition of finance capital. I therefore provide evidence for the multidimensionality of the causes for uneven development.

Table 5.1 illustrates the differences between value added and opportunistic funds with regards to the finance strategy in order to achieve the target return. The value added investment fund runs for between five and seven years and it has a target return between of 11 and 15 percent per year. The most important factor for achieving return on investment is income from rent, followed by leveraging through high debt financing based on low interest rates. The opportunistic investment is more short-term oriented with a period of around three years or less and a target return of 16 percent and more. The focus is clearly on leveraging (see sections 5.4.2 and 0 for a more detailed discussion of their finance strategies).

\footnotetext{
${ }^{93}$ In order to make above average returns on the invested equity, a disposition of the investment is necessary. Therefore, investment funds are always temporary. The funds have a finite period of between three and twelve years and generally end once the "opportunity has been realized in order to generate higher rates of return" (Linneman 2004: 149). There are several possible exit strategies. First, the investment fund can be refinanced through new investment. Second, the real estate can be securitised for trading on the secondary market (Rottke 2004: 116). Third, the investment can be sold after the achieved aim of the fund. Fourth, the investment fund can go public (Linneman 2004: 156). The analysis here however, is focused on the mechanisms of investment funds while they are active. Since the specific exit strategies are not revealed in advance, here they only play a subordinate role in terms of exit timing.

${ }^{94}$ See Brueggman and Fisher (2008) for an extensive list of strategies.
} 
Table 5.1: Relative Importance of Strategies for Different Investors

\begin{tabular}{|c|c|c|c|}
\hline & \multicolumn{2}{|c|}{ Investment Strategy } \\
\hline & & $\begin{array}{l}\text { Value Added Investment } \\
\text { 5-7 years }\end{array}$ & $\begin{array}{c}\text { Opportunistic Investment } \\
3 \text { years and less }\end{array}$ \\
\hline \multirow{5}{*}{ 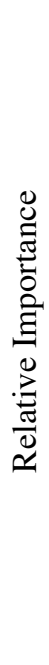 } & Target Return & $11 \%-15 \%$ & $16 \%+$ \\
\hline & Rental Income & & \\
\hline & Leveraging & & \\
\hline & Diversification & O & 0 \\
\hline & Legislation & O & 0 \\
\hline
\end{tabular}

Note: The bigger the point, the more important is the respective strategic consideration. Source: adapted from LaSalle Investment Management (2009), see also Rottke (2004: 87).

The two investment strategies are however not as easily distinguishable in reality. The specific strategy is also adjusted to the prevailing market situation. The market situation during the global financial crisis in 2008 and 2009 made leveraging and re-selling a lot more difficult (see section 5.3.3). Investment funds could no longer exit the market and especially opportunistic funds had to change their strategy, becoming more dependent on rental income. A former project manager of an investment company explained how investors adjust their strategy based on the prevailing market situation:

"If someone had arrived with an offer to buy the estate for 1,200 Euros per square metre, the investor would have sold it right away.

However, if - like in the current situation - no one is here to buy, then an investor automatically becomes a long-term investor and he then also likes to emphasise this, because everything else would be a confession to have had the wrong strategy." (Former project manager for the development of a housing estate employed by an asset management company, ID 13)

This underlines the claim made above (see section 5.3.3) that demand for the use of housing is independent from the demand for investment. However, when the speculative investment strategy fails as it did with the financial crisis, demand for the use of housing ends up playing a more important role. How great of a role depends however on the specific strategies of the investment fund. The specific finance strategies of the two investment funds affect the investment, management, and exchange strategies 
differently, creating processes of uneven development. The following sections explore the two diverging investment funds in more detail, analysing how they play out in practice under Berlin's housing market conditions and global financial market conditions.

\subsubsection{Investment, Management, and Exchange of Value Added Funds}

As Table 5.1 shows, the value added real estate private equity fund makes its return on investment predominantly through rental income since it is generally a secure and low risk strategy. Rents are relatively stable, meaning they can be relatively well budgeted when acquiring the housing estate. However, the focus on rental income makes value added investment funds dependent on local housing market conditions and regulations. Large-scale value added investment funds therefore balance specific local market conditions with geographical diversification of their investment portfolio. As such, smaller investment funds have fewer possibilities for diversification.

Value added investment funds optimise their rental income through the appreciation of property with development potential to rent or sell the property at a higher price, thus making a higher capital gain (see also Brueggeman and Fisher 2008). Property has development potential if the incoming cash flow (i.e. rent, government subsidies) is greater than the funding costs (i.e. interest rates on borrowing) and management costs; or if the potential profit when selling the housing estate is judged to be high enough. The determining factors for this evaluation are the location and the quality of the housing, the tenure structure and the credit conditions (see also Whitehead 1999).

In order to increase cash flow from rental income, value added investment funds additionally apply an efficient management strategy. This can be achieved by outsourcing the management of the housing estate or through more flexible working contracts for the employees within the housing company (Holm 2010). The imperative to reduce costs and therefore increase the net cash flow, leads to a reduction of the maintenance budget and a restructuring of services. This is evident in cases where funds bought an entire housing company and "also own the claim on the creativity and execution skills of the people at the company" (Linneman 2004: 115; Rottke 2004: 131 et seq.), meaning that the fund has the possibility to take over the team, restructure it, or make it redundant.

The finance strategy of value added funds involves less risk because it depends on rental income, making the fund dependent on local market conditions including regulatory conditions such as rent regulations. The following section explores how this finance strategy influences the contingently emerging investment, management, and 
exchange mechanisms of value added investment funds under the specific market conditions of Berlin.

\section{Creating added value through a selective portfolio strategy}

The investment funds, which bought housing in Berlin with the aim to create added value, cherry-picked housing estates with development potential. This was perfectly logical and sensible from their point of view and Berlin's housing market offered the conditions to do so. Value added investment funds selected good quality housing estates in attractive locations for their investment, predominantly in late $19^{\text {th }}$-century block developments and housing estates from the 1920s and 1930s (see chapter 4). The rent gap between the existing rent level and the possible rent increase after modernisation or refurbishment that adds value to the property, shaped the investment decision. A principal of an investment firm described the selection process for investment:

"We look where in the city we invest. We look if it is centrally located, how good the infrastructure is, and if there is a potential for increasing the rent level. We only invest in the property if we know that we can realise higher rents afterwards." (Principal of an investment firm, ID 7)

In the cases where the investment fund bought an entire state-owned housing company, it inevitably also acquired housing with less or no development potential because state-owned housing companies constructed and managed former and current social housing of the post-war period (see chapter 4). This was specifically the case for the investment fund that acquired the largest state-owned housing company in Berlin. At the same time as concentrating investment in properties with development potential, the value added funds that also acquired housing without development potential divested these housing units as quickly as possible. The added value funds therefore sold post-war high-rise developments in disadvantaged or unpopular areas where investment costs were often deemed too high for making capital improvements. The portfolio manager of a privatised company confirmed this selective portfolio strategy, illustrating the influence of the physical outcome and the rent levels for the different types of housing:

"We clearly invest in a way to make capital improvements. This means, we increase the rent levels, we lower the vacancy rates and we invest where we see potential for appreciation and divest where there is no potential for appreciation." (Portfolio manager of a private housing company, ID 12)

Divesting part of the portfolio however, did not mean that the company made a loss on it. While credit capital was available, the housing company could sell the housing estate with no development potential for a higher price than it acquired the estate because there was a demand for housing investment. There is thus always more than one 
way to make profit. This strategy was however only possible when demand for investment in housing was high enough, fostering investment from other speculators. When the hype in Berlin abated as a result of the financial crisis (see section 5.3.3), investment funds could no longer divest. Value added funds therefore began to neglect the housing with no development potential.

This selective investment in housing with development potential and the divestment or abandonment of housing without potential starkly contrasts with an expectation that housing companies invest in all types of housing equally. Moreover, the analysis shows that investment funds, and the housing companies they own, selectively invest according to their finance strategy. This uneven mechanism is especially strong in Berlin due to the specific market conditions where market failure exists in certain housing segments (see chapter 4). In an ideal-type of well functioning housing market, investment and improvement in the housing stock is meant to be profitable because there is enough demand for housing - also in less prosperous neighbourhoods. In the case of Berlin, where demand in certain market segments is not high enough, housing companies are not able to realise profits by investing in these segments. They therefore invest very strategically, meaning selectively.

\section{Reducing management costs through an efficient management strategy}

In order to increase rental income, value added investment funds chose to optimise management of the housing by creating efficiency models. In the cases analysed, three specific processes could be identified as part of an efficient management strategy: the restructuring of the organisation, the reduction of tenant services, and the reduction of neighbourhood engagement. The deputy director of one of the umbrella tenant association summarised these processes, illustrating how the reduction of management costs has real consequences for the housing provision and more specifically the tenants:

"I don't have any exact numbers because it is also not evident from the company's annual report, but this is information we have from an employee of the company: The budget for maintenance has been reduced by a third. This is quite important for tenants. The company has also undergone major personnel restructuring and it has dissolved the service centres for tenants in the districts. Now, they operate one central hotline." (Deputy managing director of an umbrella tenant organisation, ID 6, see also Holm (2010))

Restructuring the organisation: In the cases where the investment fund bought the entire state-owned housing company, a major restructuring of the company could be observed. This was especially true for the second state-owned housing company that 
was also privatised. While the first privatisation entailed a negotiated protection for the employees of the state-owned housing company, the second privatisation focused more on the protection of tenants. ${ }^{95}$ The second privatised housing company has undergone major restructuring of personnel; the new board of directors exchange of managers; and a new wage model was introduced, promoting flexible work hours (Holm 2010).

The same mechanism also took place in the cases where the state-owned housing companies privatised an estate. In this case, the state-owned housing company transferred the management team for the particular estate along with the estate. The stateowned housing company therefore also transferred the claim on how to manage the estate. The fund took over the two employees from the state-owned housing company and integrated them into the management team it established for the housing estate. The employees however, did not fit into the new management philosophy and left the management company shortly after (see ID 29).

Reducing tenant services: The reduction of personnel within the housing companies or the restructuring of services created a deterioration vis-à-vis customer liaison and support. Traditionally, tenants had a direct link to the state-owned housing company that was on-site with a service centre. The privatised housing companies have centralised the service centres or reduced their business hours. Increasingly, the tenant organisation received more complaints from tenants.

"The reduction of access for tenants has been taken negatively by tenants. It has to be said that the state-owned housing companies were also not optimal in their management. However, the service has definitely deteriorated. That is obvious, because the housing company has reduced the personnel and has rented out the former service centres to generate more income through commercial rents." (Deputy managing director of an umbrella tenant organisation, ID 6)

The abandonment of the service centres created greater distance between the tenant and the housing company. The service has become more anonymous. This makes the relationship between the owner and the tenant also less transparent. This mechanism was reinforced in cases where ownership constantly changed through the re-selling of housing estates. With constantly changing owners that were often represented through a property management firm, it became less transparent to the tenant what strategy the owner pursued. The emphasis on profit maximisation and the indifference of the fund towards the specific location and housing development further created insecurity

\footnotetext{
${ }^{95}$ The different emphasis on protection of employees and tenants in the two cases was because the trade union of the first state-owned housing company to be privatised was successful in negotiating a deal, which however meant concessions on tenant protection. When the second state-owned company was privatized, the tenant associations had more power to influence the negotiated sales contract.
} 
among tenants. An urban planner explained the relationship between the new owners and tenants:

"When there is an investment fund that buys the housing, the fund is often from Luxembourg or Switzerland or anywhere else and is represented through another firm that is not locally situated. But the owners are even less reachable because they are in the US or Australia. And they are not interested in the condition of a particular apartment or if the tenant is dislocated, but they have bought it to make a profit and the manager of the estates are expected to implement this profit target." (Urban planner, member of a district parliament and head of the district's urban planning commission, ID 15)

Reducing neighbourhood engagement: The third form of efficient management that could be observed was a reduction of the privatised companies' commitment to support the neighbourhood and its activities. While state-owned housing companies had a long tradition of supporting and initiating neighbourhood activities, privatised companies often no longer felt responsible to go beyond their core business of managing housing. The pressure to reduce costs became very apparent. A collaborator of a tenant consulting service described the relationship they have with the privatised company:

"We generally have a good relationship with the [privatised] company that is in charge of this neighbourhood. However, we notice that depending on the current direction from above, he [the company's person in charge of the estate] is more or less responsive to our proposals. Sometimes, he says that the company is in no way able to help out. Sometimes, he is more open for our projects as long as it does not cost too much money for them." (Collaborator of a tenant consulting service, ID 21)

This mechanism is strengthened because while state-owned housing companies were traditionally anchored in specific neighbourhoods, privatised housing companies often re-sold a majority of their housing units in an area and therefore no longer felt responsible to support the area. The consequence of the diversification of owners in a neighbourhood is therefore an increasing lack of responsiveness on the part of the owners. The head of public relations of a privatised company confirmed the reduced commitment due to the smaller housing stock in the area:

"We do invest in public infrastructure such as playgrounds and parks within the housing development. We do that of course not with a philanthropic aim, but with the aim to improve the neighbourhood and therefore create positive effects. However, and this is what we are criticised for at the moment, we do it within the dimension we feel responsible for. And because we are no longer owning 15,000 units in the area, but only 2,000 units, our commitment is reduced accordingly." (Head of public relations of a private housing company, ID 23) 
The value added investment funds restructured the housing companies and reduced personnel. They consolidated tenant services through the closure of service centres and trimmed down their engagement in neighbourhoods. However, since value added funds aimed to increase rental income streams, they could not cut key services to tenants such as maintenance under the particular market conditions. In Berlin's housing market situation, a considerable deterioration of maintenance and services would have lead to higher vacancy rates. Better off tenants had relatively good options to relocate if they were not satisfied with the services provided by their housing company. The value added funds therefore, needed to provide a certain standard if they wanted to make their return on investment through the rental income stream. Because of this mechanism, the organisational restructuring of a housing company played a more important role in creating efficient management than the reduction of frontline services. The everyday life of tenants was therefore not dramatically impacted when a value added investment fund owned the housing.

The tenant was however affected by rising rents. Having analysed the investment and management strategies of value added investment funds, the next two sections turn towards exchange strategies, looking at how value added investment funds increased rent levels and apply exclusionary allocation strategies.

\section{Increasing rent levels through modernising the housing stock}

In order to make the investment profitable and achieve their target returns, value added investment funds increased the rent levels and attracted a clientele with a higher socio-economic status after modernising the housing with development potential. The head of public relations of a housing company confirmed this:

"We invest in the housing stock and furnish dwellings with attributes that increase the quality of the housing, either through energy saving means or through the improvement of kitchen, bathrooms, floors, outdoor façade, etc. in order to newly place them on the market, mostly in a higher segment." (Head of public relations of a private housing company, ID 23)

The possibility to increase rent levels however greatly depends on the housing and rent regulation. Berlin's existing rent regulations are discussed in more detail in chapter 7. Two points are important to understand here: First, rent regulations only apply to existing tenant agreements. Tenants often did not want to bear lengthy renovation periods so they moved out before it started. By announcing modernisation projects, investors created even higher vacancy rates which were already high enough because of substandard housing conditions. This suited them well because for new tenancy agreements there is no rent regulation allowing them to increase rent levels reflecting 
market conditions. A portfolio manager confirmed the benefit of high vacancy rates during renovation:

"Best is of course, if the whole estate is emptied. We had a vacancy rate between 30 and 50 percent. And of course, we would have preferred to boot out everyone, but that is of course not possible. Then you have to deal with the retired and the alcoholics, which makes the situation more complex." (Director of a real estate fund at a bank, ID 16)

The second point of rent regulation, which is important here, is that investors can partly transfer modernisation costs onto the rent. This means that even if a tenant decided to bear the renovation period and was therefore protected by existing rent regulation, the regulatory conditions allow investors to partially transfer modernisation costs onto rent levels. This particular regulatory mechanism created an incentive to modernise the housing to a high standard. Tenants affected by modernisation were however, often not able to bear the higher rent levels after modernisation. The tenants living in these substandard housing estates were often the socially disadvantaged. This remaining clientele therefore, starkly contrasted with the investors' aim to renovate to a high standard and increase rent levels. A district parliamentarian and urban development consultant summarised the effects on the existing tenants when modernisation was announced in the neighbourhood of a 1930s row development:
"It was already feared and it also happened that after the privatisation of the housing company owning this estate, the modernisation of the estate was announced. The modernisation process was then also any- thing but pleasant for the tenants. It was clear that the now privately owned housing company wanted to renovate the entire estate and ex- change the tenants because the existing tenant structure was not what the company wanted. It wanted to have a clientele that is able to pay higher rents and it wanted to restructure two-room apartments into big family homes also with the possibility to sell it afterwards as owner- occupied housing units. That was catastrophic for the existing tenants, because a high percentage of elderly people lived there. Some moved into these apartments in the 1950s. It was horrible for them that they had to move because their apartment was getting renovated. A similar high percentage of people on social welfare lived in these estates. They were not able to bear the higher rent levels." (Urban planner, member of a district parliament and head of the district's urban plan- ning commission, ID 15)

The modernisation process was anticipated, and even wished for, when the government privatised the state-owned housing companies (see section 5.1). However, the particular way the mechanisms of modernisation and increasing rent levels played out generated two processes of tenant dislocation: First, the value added investors' appreciation of the housing stock in better locations created a direct displacement of 
existing tenants. Second, it also produced an "exclusionary displacement" (Marcuse 1986: 156) whereas households voluntarily vacated, but the barriers for new tenants to move into the neighbourhood were heightened. The exclusionary displacement is thus a process of gentrification which was induced by voluntary means.

The process of modernisation that was anticipated through the privatisation of the state-owned housing legitimates the exclusion of the poor and vulnerable tenants. The modernisation therefore is not for the benefit of the existing tenants, but only for the wealthier ones in future. The barriers for moving into a modernised apartment are however not only heightened through increasing rent levels, but also through investors' specific allocation strategy.

\section{Excluding low income households through a selective allocation strategy}

Value added investment funds not only physically, but also socially upgraded their housing stock. They aimed at upgrading the social structure when tenants vacated their homes voluntarily or involuntarily. Value added investment funds excluded disadvantaged households with a selective allocation strategy. A portfolio manager confirmed this selective allocation strategy:

"We have clearly an allocation strategy, you can't call it racist, but we do not rent out to a single alcoholic for example. I have two letting teams and they have clear instructions which profile they should rent out to. We want to have families with children. We are also lobbying for a kindergarten nearby. And we have kicked out the pub at the corner of the housing estate." (Director of a real estate fund at a bank, ID 16)

The allocation strategy of the investment fund shows that a logical mechanism based on the finance and investment strategy of value added funds has uneven effects on the housing provision and consumption relations.

Similarly to the exclusion of the poor, immigrants were often not welcomed in the upgraded housing stock because it could deter German middle class families from moving into the area for such reasons as the schooling of their children. This mechanism was also confirmed in an interview:

"The new investors take into account the demand in regards to the German groups who wish to live in homogeneous neighbourhoods. The investors have tried to create these neighbourhoods, for example in the row developments. Only middle class households that are traditionally anchored and things like that. This minimises conflicts and creates in the investor's view a stabilised tenant structure which the investor's housing company also advertises. They argue that they are contributing to an important stability for the neighbourhood and there- 
fore the city. It however means nothing else than that they displace the problems to other neighbourhoods, mostly to those in the outskirts." (Deputy managing director of an association for housing and urban development, ID 8)

The allocation strategy of value added investment funds therefore reinforce uneven development processes by shaping the exclusionary consumption of certain types of housing such as the $19^{\text {th }}$-century block developments or the 1920 s and 1930 s row developments in good locations.

\section{Value added investment funds shape an exclusive form of consumption}

Consumption emerges through aggregated demand. In order to understand the influence of consumption on processes of uneven development, the explanatory model (see section 3.2) defines consumption in terms of income and household structure. These categories help to understand how aggregated demand increases or decreases under specific conditions. The expressed demand of occupants however strongly depends on production mechanisms.

The appreciation of the housing stock created by the investment, management, and exchange strategies of value added funds shaped an exclusionary demand for middle and upper income classes. The modernisation of the housing stock made living in the $19^{\text {th }}$-century block developments attractive and therefore created a demand from the professional middle class whose taste is oriented towards particular aesthetics of the inner city (Ley 1996; Hamnett 2000). Berlin's economic transformation towards a post-industrial city, with decreasing manufacturing jobs and an increasing labour force in business services and cultural industries (see chapter 1), contributed to the demand of $19^{\text {th }}$-century block developments in the inner city. Equally, Berlin's reunification made inner city living attractive again. The fall of the Berlin Wall opened up previously deserted land. The consumers of the $19^{\text {th }}$-century housing developments consisted then of the incoming government workers, the growing business class, and a rapidly expanding number of creative entrepreneurs, often from abroad.
"A very important process here in Berlin is that people from other EU countries enter the housing market. People from Britain or Denmark, to mention just two, who can afford a flat in London, can afford here the whole floor. Thus, the proportion of immigrants has not necessa- rily changed. But the immigrants living here are no longer Turkish people, but come from other EU countries." (Collaborator of a tenant consulting service, ID 21)

Value added investment funds have upgraded the housing stock, a task that most of the indebted state-owned housing companies were no longer able to provide without state subsidies (see section 5.1). The privatisation process therefore fostered the 
state's anticipated modernisation of the housing stock, however only in the market segment where investors saw potential for higher rents to achieve their target return. Under the existing market conditions, value added investment funds invested in the $19^{\text {th }}$-century block developments and the Twenties and Thirties row developments in well-situated areas. At the same time, they divested or neglected post-war high-rise developments. It is then also the modernised housing in better locations that was most affected by higher rent levels. Housing in the lower market segment, for which demand was not high enough to make investment profitable was divested or neglected. The uneven investment process is reinforced through the particular allocation strategy that value added investment funds followed regarding the housing with development potential.

This analysis underlines the argument that the uneven investment mechanisms and outcomes of the privatisation process are not because of the privatisation per se, but because of the particular contingently emerging production mechanisms of the value added investment funds. The same process of privatisation led to differential outcomes as a result of how value added investment funds modernised or neglected the different types of housing. The differential outcomes were however also due to investors' diverging strategies. Value added investment funds were only one type of capital investment acting in Berlin's housing market. The other type that was observed is the opportunistic investment fund. The next section turns towards opportunistic investment funds, investigating their contingently emerging finance, investment, management, and exchange strategies.

\subsubsection{Investment, Management, and Exchange of Opportunistic Funds}

Compared to value added funds, opportunistic investment funds target higher returns within a relatively short time span. In order to achieve this return, rental income plays a less significant role for opportunistic investment funds. Opportunistic real estate private equity funds' main yield strategy is financial leveraging (see Table 5.1 and Rottke (2004: 87)). Financial leveraging is the profit that occurs when the interest rate is lower than the return on the total investment in a property. Thus, "[i]f the return on the total investment invested in a property is greater than the rate of interest on the debt, the return on equity is magnified" (Brueggeman and Fisher 2008: 348). If this is the case, investing with high credit capital and low equity is advantageous because it increases the return on equity. This has the effect that profit is to a great part not resulting from a particular investment project, but from the degree of credit capital on the investment (Rottke 2004: 145). However, leverage "works both ways in the sense that it can magnify either returns or losses" (Brueggeman and Fisher 2008: 352). The more credit capital invested in the property, the higher the loss when the property is de- 
valued or interest rates rise. The higher the debt on the investment, the higher is the return in good times but the greater the loss in hard times. Leveraging is a more risk prone strategy because it depends to a greater extent on the availability of cheap credit capital. It is therefore more exposed to the volatility of interest rates.

Since opportunistic investment funds make their return through financial leveraging, their objective is to buy cheap and re-sell at a higher price as soon as possible to make profit on the credit capital. Winograd (2004: 205) summarises the opportunistic strategy: "buy as much as they could, leverage it as much as they could, and wait for markets to recover." As soon as the investment target is achieved, the housing is re-sold to another investor. For opportunistic investment funds, the availability of good credit conditions and a belief that the specific market for capital investment is still cheap but on the rise is therefore significant. These funds are more specialised on the trading aspect of real estate than on the management side. Often, they do not have in-house real estate expertise, but are solely financial engineers.

Due to the opportunistic funds' focus on trading, the possibility to increase rent levels by adding value is not relevant to them. Therefore, location and the condition of a housing estate are often neglected at purchase. Linneman (2004: 126) explains this neglect: "In fact, even a property with little or no residual value can still be extremely valuable." This starkly contrasts with theoretical concepts such as the rent gap theory (Smith 1996) which postulate that profit is achieved through increasing rent levels. If a leveraging effect is possible, the existing and potential use value of the housing estate has no priority. A portfolio of lower value housing is sometimes even actively sought because of the low purchasing prices. The following sections explore how this particular finance strategy influenced the contingently emerging investment, management, and exchange mechanisms of opportunistic investment funds under the specific market conditions of Berlin.

\section{Making profit through buying cheap and selling high}

In Berlin at the beginning of the 2000s, the availability of housing at low prices combined with easy credit (see section 5.2) promoted investment from opportunistic funds. They bought housing estates from state-owned housing companies, but also from value added investment funds that divested the housing units without development potential (see section 5.4.2). In line with their profit-making strategy through leveraging, regulatory conditions did not play a role because they aimed to re-sell the housing and were therefore only marginally affected by rent or planning regulations. A fund manager confirmed the funds' ignorance when purchasing housing: 
"For financial investors, things like preservation orders, rent regulations or difficulties with existing tenants are negligible details. They almost never appear in Excel-Spreadsheets. Investors did not look at these details, they saw the cheap housing and the cheap money and they wanted to enter the Berlin market." (Director of a real estate fund at a bank, ID 16)

Not only did regulatory conditions not play a role, opportunistic investors also followed a portfolio strategy where they sought to buy the cheapest housing in order to re-sell it at a higher price. As a result of this investment strategy, the existing or potential value of the housing estate played a subordinate role. Opportunistic investment funds bought the cheap post-war high-rise developments - often formerly or currently within the lock-in period of social housing (see chapter 7). They did not analyse the specific housing conditions (ID, 16). While credit was easily available and demand for investment high, opportunistic funds could count on the 'bigger fool', another investor that buys at an even higher price. The investment therefore was pure financial speculation, based on the assumption that the investment hype will continue. A representative of an investment firm explained the bigger fool theory:

"Investors just buy prefabricated housing ${ }^{96}$ and try to re-sell it as fast as possible at a higher price. This is called the 'bigger fool theory'. That worked very well in the last years, not so much anymore nowadays." (Principal of an investment firm, ID 7)

This strategy works well in a rising market. The hype that existed in Berlin's housing market provoked the trading activities of opportunistic investment funds. The strategy however, no longer worked when the financial crisis hit investment funds and investment came to a halt. Credit capital was no longer easy available and the market collapsed (see section 5.3.3). Due to their high debts that became difficult to refinance, opportunistic funds ran into difficulties to serve their credit line. The portfolio manager of a fund explained the risk of investing with high credit capital:

"We have around 60 percent credit capital. Everyone wanted me to increase this, but I refused to do it. Healthy is a credit capital of 55 to 60 percent; everything above is pure financial speculation. In crisis times like these, we are now of course heroes, because we can pay the interest on our credit. I am coming from the real estate sector and not from the financial sector." (Director of a real estate fund at a bank, ID 16)

Opportunistic investment funds were therefore forced to change their strategy in order to be able to serve their credit line. Since opportunistic funds were indifferent to the type of housing they bought, they were often stuck with housing that did not have socalled development potential. These housing estates were in desperate condition and

\footnotetext{
${ }^{96}$ The prefabricated housing built by the GDR government in the outskirts of East Berlin are considered low standard housing today because they are very monotonous high-rises with outdated amenities (see chapter 4.3).
} 
often suffered from high vacancy rates because state-owned housing companies were not able to stem the costs of renovation (see section 5.1) and value added investment funds did not want to pick up the costs for renovations (see section 5.4.2). The opportunistic funds' indifference towards housing also shaped their management and exchange strategies. The next sections analyse how these strategies contingently emerged.

\section{Reducing expenses through neglecting maintenance}

In order to get the full positive effect of leveraging, opportunistic investment funds reduced expenses to a minimum while a new buyer was sought. This is how they increased income, and therefore the difference between the profit and the interest rate, in order to maximise the leverage effect. Opportunistic investment funds reduced the management and maintenance of the housing estate to the most possible minimum. This efficient management strategy saves costs, but affects tenants' homes.

The opportunistic investment funds did not make the necessary renovations. Moreover, they cut caretaker jobs only replacing them once they were forced to change towards a longer-term strategy. When replacing the caretakers, the funds replaced them with cleaners who generally have lower salaries. They also reduced customer service to a higher extent than the value added investment funds. Opportunistic investment funds allowed the already problematic housing estates to further deteriorate. A district councillor and a neighbourhood manager confirmed this process for one of the cases analysed:

"The estate has been rundown. The caretaker jobs were cut. The investor's policy is a different one than the one of the state-owned housing company that owned the estate before." (District councillor for social welfare, housing and environment, ID 22)

This is in stark contradiction with the state's intention to trigger renovation of the housing which could not be stemmed by the state-owned housing companies. The deterioration of the housing estates was an unintended consequence of the privatisation process which was in exact opposition to its stated goal. Failure to perform the necessary renovations was curbed in one case: The state forced the purchaser to renovate the housing estate by adding a condition to renovate the estate in the sales contract. In this case, the investor had to renovate the housing estate for a certain predetermined amount. However, this was only possible because a state-owned housing company sold the housing estate. When housing estates were re-sold from investor to investor, they did not force on each other renovation responsibilities. 
Where the state enforced a renovation process, the state did not interfere in the way the estate got renovated, but only controlled the amount that got invested. This enabled the opportunistic investment fund to set the priorities in spending the agreed amount. The state could therefore not control the consequences. In the case where the state enforced this renovation process, the director of the state-owned housing company and the neighbourhood manager in charge expressed their disappointment at the renovation process after privatisation.

"It is correct that in the sales contract we agreed with the investor on a certain amount that needs to be invested in the housing estate for renovation until 2010. We have also accompanied this process with an external expert and the money that we agreed upon will be invested until 2010. However, the renovation was not done as intelligently and professionally as we had wished for." (Managing director of a stateowned housing company, ID 28)

"The renovation has been anything else than pleasant because the quality is very poor and the tenants are very discontented, also because they were promised more at the beginning than what was done in the end. [...] We also had problems with the windows. They were only painted and sometimes even when it was wet. That means the tenants have now leakier windows than before." (Project director of a neighbourhood management team, ID 29)

The decline of the housing estate affected the everyday life of the residents. Living in a run down estate became increasingly unpleasant, especially when garbage was no longer collected and staircases no longer cleaned.

"When the estate was privatised the lack of cleaning of the estate became unbearable. It was so dirty in the communal areas outside and inside the estate. For weeks there was no cleaning, so that the tenants started to ask why they still pay rent. Now the property manager emphasises the fact that he newly employed these cleaners. However, these are not real caretakers." (Project director of a neighbourhood management team, ID 29)

In contrast to the efficient management of value added investment funds, opportunistic investment funds were, at least as long as they followed their short-term strategy, not dependent on rental income. Therefore, they could not care less how well the housing was managed. The effects on the housing and the tenants analysed here were therefore more dramatic compared to the ones of value added investment funds' management strategies. Even after the opportunistic funds changed their strategy in order to be able to serve their credit line, they saved costs by keeping maintenance at a minimum. This neglect however, generated higher vacancy rates which had to be diminished, especially once the opportunistic investment fund started depending on rental income. Rent levels were therefore lowered and letting strategies were aggressively targeting low income households. 
Due to the neglect towards the condition of the housing estate, vacancy rates rose. Once the market collapsed and the opportunistic fund had to seek ways of serving its credit line, the reduction of vacancy rates became crucial to the new strategy. The managing director of the responsible property management firm confirmed that the investment fund behind the housing development sought a rapid re-sell and explained the new strategy:
"Because of the banking crisis at the moment, the plan to re-sell has been modified, because the price that the investor aimed for is not achievable. No investor is currently able to get the credit for paying such a price. This is why the investor decided to go for a longer-term strategy. That means we have to ensure that the credit line can be served and therefore we need to have the estate fully rented in order to deal with the current situation." (Managing director of a property management firm, ID 30)

Since the estate was poorly maintained, opportunistic investors ran into increasing difficulties attracting new tenants and achieve a full occupancy rate. They were also not able to increase their income streams through higher rent levels due to the depressed situation in these lower market segments. Opportunistic investors therefore created what Holm (2010) calls 'discount housing'. Because they had to reduce vacancy rates in order to increase their income streams, they also accepted lower rent levels. The director of a property management company confirmed their attempt to reduce vacancy rates, even accepting lower rent levels:

"We aim at a vacancy rate of five percent. This is however very difficult. We have to work hard for it and we have to move away from a strategy with high rents. We say, we want to rent out the apartment to generate a rental income stream and if we can't get 5 Euros, we have to accept 4.80 Euros [per square metre and month]." (Managing director of a property management firm, ID 30)

This shows how rent levels depend on specific market dynamics and the type of housing within this market. Privatisation of state-owned housing does not necessarily foster increased rent levels in the privatised housing stock. The particular way in which opportunistic investment funds finance their investments strongly contrasts with an expectation that private-led housing contributes to higher rents. There is more than one way of generating return on investment. The particular way investment funds choose to make their return under the given market conditions influences the way they manage the housing stock and determine the rental rates. The particular finance strategy also influences the way funds allocate housing to tenants. 
Lower rent levels were not sufficient to attract new tenants, especially because the estate acquired a poor reputation due to neglect in maintenance. The fund therefore increasingly applied aggressive letting strategies, indifferent to the tenant that was moving into the housing unit. The fund hired an external agency, which it paid on the basis of the amount of housing units rented. The letting agency advertised the apartment specifically to people with a poor credit history and promised new tenants three months rent free and a voucher of 200 Euros redeemable at a home improvement store (Du Chesne Immobilien GmbH 2009). A district head of a tenant association heavily criticised this strategy:

"Other owners get also better off tenants, but they are committed to get the better off ones. It is simpler to get the apartments filled by advertising it with strategies like handing out 250 Euro vouchers for Media Markt ${ }^{97}$. This is how they get the apartments full. However, this is not sustainable because as fast as these people move in, the better off ones become angry and move out just as fast." (District head of a tenant association, ID 27)

This discount housing strategy implemented by opportunistic funds is in contrast with Besecke and Enbergs' (2008) findings that state-owned housing companies are the only actors that provide housing for the disadvantaged because neither housing associations nor the privatised companies are willing to accommodate them. The analysis shows that opportunistic funds also provide housing for the socially disadvantaged. However, they are motivated by the possibility of decreasing vacancy rates and not by any social responsibilities they feel towards their tenants. The objective of opportunistic investment funds is therefore not quite the same as the state-owned housing companies' political mandate to provide housing for the more vulnerable ones (see chapter 6). This indicates that a dualistic interpretation of privatised versus stateowned housing is not helpful in understanding the particular mode of housing provision and its consequences on uneven development. ${ }^{98}$

The opportunistic investment funds' strategy of buying cheap and selling high while ignoring to maintain housing estates and pushing for lower vacancy that favour low income households, shapes the consumption of such housing estates. In this last section, the opportunistic investment funds' production mechanisms are analysed with regards to their effects on the changing consumption relations of housing.

\footnotetext{
${ }^{97}$ A famous media chain store in Germany.

${ }^{98}$ I develop this argument further in chapter 6.
} 
Due to the neglect of the estates, households with a higher socio-economic status moved out. In the market conditions of Berlin, these households were able to find a housing estate that is better maintained. This is in contradiction with a tight market situation where tenants cannot necessarily vote with their feet. The tenants who then moved into the housing estate owned by the opportunistic fund were the ones that did not have access to other market segments. The majority of these tenants were on social welfare. The fact that the job centre, which is in charge of benefits for people on social welfare, guarantees the rent payment, created further incentives for the opportunistic fund to rent to tenants on welfare. Often, the tenants who had no access to other market segments were also immigrants:

"In the last year, thanks to the letting agency, we had an increased influx of Roma. They were not in one apartment but in four apartments and that was enough. This year, there is an increased influx of Arab families, many among them very religious. We have a mosque nearby, which is observed by the Federal Office for the Protection of the Constitution. These are all things that cause distress." (Project director of a neighbourhood management team, ID 29)

The influx of different nationalities and ethnic groups also affected the everyday life of other tenants, creating conflicts within the estate because of their different degrees of integration into German society. While Turkish people as non-EU immigrants, for example, have to attend language courses, Roma and other EU immigrants do not need to demonstrate any language skills. These conflicts further deteriorated the reputation of the housing estate:

"It is dirtier and louder in the estate, there is a complete indifference towards it. All problems we had before, but not to such an extent. And the arrival of the Roma families last year created conflicts because they released a wave of grudges among other immigrants because they do not speak German. And in comparison to the Turkish people who move here and who have to show that they attend a language course, the Roma do not have to do this. They rented an apartment and thirty people lived in it. The staircase was used as a toilet and they drank without limits." (Project director of a neighbourhood management team, ID 29)

The neighbourhood management tried to counter the downward spiral of an influx of people on social welfare by collaborating with the job centre. Since the job centre has to approve the apartment of someone on social welfare, the neighbourhood management tried to interfere so it would not approve everyone for the specific housing estate. This way, the neighbourhood management hoped to force the investor to increase its efforts to attract a clientele with a higher socio-economic status. The manner, in which opportunistic investment funds function however, makes it extremely difficult 
to establish a social mixture in this type of housing estate. Moreover, under the specific market conditions, the contingently emerging investment, management and exchange mechanisms of opportunistic investment funds actively created a concentration of lower-income households. This is in stark contrast with the value added investment fund that displaced lower-income households and created enclaves of affluent tenants in inner city neighbourhoods.

The concentration of the more vulnerable tenants in certain areas of the city is a common phenomenon (Van Kempen and Priemus 2002). The analysis of the contingently emerging production mechanisms of value added and opportunistic investment funds shows the particular way this concentration came about in specific circumstances. The concentration of the socially disadvantaged is not solely generated through their displacement from inner city housing. It does also not solely happen because low income tenants are living in social housing (compare chapter 7). Concentration is also actively created through the opportunistic investment funds' specific finance, investment, management and exchange strategies. These mechanisms contrast the normalised expectations where finance capital creates pockets of gentrified neighbourhoods, where high-income households displace low income tenants who have nowhere to go.

\section{Conclusion}

The government's privatisation of state-owned housing companies and housing estates diversified the type of providers in Berlin's housing market. The en bloc selling and the aim to make the highest profit possible to restore the precarious financial situation of the city, favoured institutional investment funds as purchasers of the former state-owned housing. At the beginning the 2000s, institutional investment funds guided by global financial market conditions of cheaply available credit capital found in Berlin's privatisation process a matching supply for their demand. They entered Berlin's housing market on a large scale through the vehicle of real estate private equity funds.

Real estate private equity funds speculated on a rising housing market where rent levels and owner-occupation could be increased. These types of funds however also speculated on a rising demand for investment independent from the use value of the housing resulting from credit availability and the matching supply. This was in contrast to the reality of Berlin's development, where the general socio-economic situation of the city did not considerably improve to trigger a higher demand for the use of housing. Demand was rising, but only in the market segments of $19^{\text {th }}$-century block developments and Twenties and Thirties row developments in inner city areas. Post- 
war housing estates at the edge of the city still suffered from high vacancy rates (see also chapter 4). Moreover, when the financial markets collapsed in 2008 and 2009, the credit capital was no longer cheaply available. Real estate private equity funds, therefore, had to deal with specific conditions; the mismatch between speculative expectations and market reality.

Under the specific market conditions, this chapter identified two types of real estate private equity funds: The value added investment fund and the opportunistic investment fund. The analysis of their contingently emerging mechanisms provides explanations for the processes of uneven development. The added value fund predominantly relied on rental income. It upgraded the housing stock in order to be able to increase rent levels. This was however only possible in the market segments with rising demand. The added value fund therefore invested very selectively, contrasting at least in part the state's intention to deploy a modernisation of Berlin's housing stock through privatisation. The increased rent levels coupled with a very selective allocation strategy followed by added value funds created enclaves of neighbourhoods occupied by tenants with a high socio-economic status.

In contrast to the value added fund, opportunistic investment funds depended on financial leveraging to achieve their target return. They purchased the cheapest, often problematic, housing estates, financed them with high debt rates and re-sold them as quickly as possible to other investors for a higher price. They did normally not invest in the housing stock. Moreover, they were completely indifferent towards maintenance and tenant allocation while they owned the estate. Trying to reduce expenses, they neglected the estates. In the market situation, where demand was only increasing for housing in the better neighbourhoods, the opportunistic funds' applied aggressive letting strategies with the imperative to serve their credit lines through decreasing vacancy rates. This fostered a concentration of socially disadvantaged tenants that have no access in the housing stock to better neighbourhoods.

The government's privatisation of state-owned housing confirms Berlin's trajectory towards a more entrepreneurial housing provision as outlined by the entrepreneurial city debate (see section 2.2). The process reduced the influence of Berlin's government, creating incentives for private investors. Moreover, because the privatised system established by the government was not fully understood by the protagonists, it produced many unintended consequences. The analysis shows that finance had driven privatisation. A balanced development is tipped in favour of attracting capital and against tenants, especially the more vulnerable ones. This was expected. The mechanisms of this privatisation process were however profoundly unequal. The chapter showed that the transformation towards a more entrepreneurial housing provision in 
itself does not explain this inequality. It is the specific way in which the privatisation takes place that produce processes of uneven development. Moreover, it is the contingently emerging production mechanisms of value added and opportunistic investment funds that create the specific processes of uneven development. The privatisation of state-owned housing did not create per se processes of uneven development, but the diverging production mechanisms under Berlin's specific market conditions did. These different mechanisms analysed in this chapter start to fill the black box between the entrepreneurial housing provision and social and spatial inequality identified in section 2.3 .

With the analysis of the privatisation process, this chapter investigated the consequences of the first transformation process of Berlin's social mode of housing regulation. The next chapter turns towards the second transformation process; the reformation of the remaining state-owned housing companies. Berlin's government not only privatised part of its housing stock, but also reformed the remaining housing companies. This generated increasing pressure on state-owned housing companies to work in a more profitable way in order to pay dividends to the state. At the same time, state-owned housing companies have a political mandate to provide housing for a broad stratum of the population and to contribute to the improvement of socially disadvantaged neighbourhoods. The next chapter investigates the tensions and uneven mechanisms of the contingently emerging production mechanisms of state-owned housing companies under particular guiding principles and compares them to the production mechanisms of the different types of investment funds identified in this chapter. 


\section{Reformation of State-owned Housing Companies}

The second transformation process towards a more entrepreneurial housing provision this thesis has identified is the state's reformation of the state-owned housing companies. In comparison to real estate private equity funds, public or state-owned housing companies have a different rational for acting in the housing market. Typically, the state provides housing for a particular income group that would not have access to housing on the free market. The provision of housing for low income households is therefore prioritised over economic profits. In Berlin, the state's reformation of stateowned housing companies challenged this rationale, creating a state-owned housing provision that can be considered as a more entrepreneurial and socially regressive form of housing provision. I argue that this is due to the particular way in which the state integrated profit-oriented goals.

In order to comply with the specific entrepreneurial and social guiding principles of the state, state-owned housing companies were forced to adapt their production strategies; become economically successful while adhering to a political mandate of providing housing for low income households. At the same time, state-owned housing companies started to feel increasing competition from a more diversified owner structure in Berlin's housing market as a result of the privatisation process (see chapter 5). This chapter addresses the question How do state-owned housing companies contingently emerge under the new guiding principles and market conditions through their finance, investment, management, and exchange mechanisms?

The chapter explores this second transformation process in three steps. First, it explores the state's reformation process of state-owned housing companies, outlining the new guiding principles they had to follow (6.1). Second, the chapter investigates how the new owner structure of Berlin's housing market shaped the state-owned housing companies' market position (6.2). Third, the chapter analyses how the stateowned housing companies influence the provision of housing structure through their contingently emerging production mechanisms, ultimately contributing to processes of uneven development (6.3). The chapter closes with a comparative synthesis of key mechanisms analysed among privatised (see previous chapter 5) and state-owned housing (6.4). 


\subsection{Reformation Enabled Berlin's Government to Redefine the Aims of State-led Housing Provision}

In principle, the state holds public housing with the goal to provide it for the socially disadvantaged and low income households (Turner and Whitehead 2002: 211). The state commonly intervenes in the housing market through supply-side housing support, especially in times of housing shortage, when housing costs tend to be too high for low income households, or private housing construction cannot keep up with a rising demand (Ball et al. 1988: 11; Golland 1998: 6; see also Harloe 1995). In comparison to private-led housing provision, public-led housing provision usually aims not to make profits through the construction and management of housing, but aims to improve "the consumption possibilities of households, either in general or for particular targeted social groups" (Ball et al. 1988: 15). The state, therefore, has diametrically opposing objectives compared to the profit orientation of private landlords. Public-led housing is non-profit oriented offering below market rents that the state subsidises. Public-led housing is associated with "socially financed, large-scale, standardized, and monotonous housing" (Lawson 2006: 68).

The practice of public housing provision is less clear. The dualistic distinction between private-led (equalling profit-oriented) and public-led (equalling low income) housing provision is in reality rarely as clear-cut as the literature often normatively asserts. It is therefore necessary to investigate the mechanisms defining public-led housing provision in more detail. This chapter addresses the particular way public-led housing provision worked in Berlin based on the interpretation of the conceptual model of regulation, production, and consumption mechanisms.

\section{Changing vision for state-owned housing fostered a reformation}

In Berlin, the government holds housing through state-owned housing companies. The state-owned housing companies are public limited companies (AG) or companies of limited liability $(\mathrm{GmbH})$ and therefore guided by private law. ${ }^{99}$ However, the government of Berlin is the sole owner. Until 1990, the state-owned housing companies

\footnotetext{
${ }^{99}$ German law makes a distinction between public and private law. Public law regulates the relationship between a citizen and the state or different entities of the state. Private law regulates the relationship between citizens or companies. State-owned housing companies, guided by private law, are legally treated as a private company and not as an entity of the state.
} 
acted as non-profit housing companies ${ }^{100}$ under the principle of the common public interest (Gemeinnützigkeit) with the aim to provide housing for a broad cross-section of the population. Housing companies under this principle benefitted from tax exemptions, but were in return limited in their profit-making. They were not allowed to pay out more than four percent in dividends, limiting profit maximisation strategies. Their field of activity was also regulated, limiting it to building and managing subsidised social housing units (see section 7.1) as well as rental units on the free market that could be no more than 120 square metres (Stimpel 1990: 104). In contrast to other public housing systems (see, for example, Lundqvist 1992; Whitehead 1999 for the UK), state-owned housing companies in Germany were therefore not exclusively operating in the social housing market; there was therefore never a sharp line between state-led and private-led housing provision in Germany (see also section 7.1).

Starting in 1990, the state's vision for state-owned housing changed. The national government abandoned the status of non-profit housing companies acting under the principle of the common public interest. The non-profit companies were no longer exempt from tax payments. At the same time, they were released from the restrictions with regards to their activities on the housing market. ${ }^{101}$ The housing companies could therefore widen their portfolio and increase profit margins. With this deregulation, these formerly non-profit housing companies became considerable income generators; the owner could extract higher dividends or sell the company. It became an opportunity to improve their financial situation, especially for owners that were under financial pressure, such as the government of Berlin. The abandonment of the principle of the common public interest for housing companies enabled Berlin's government to change its strategic goal for holding state-owned housing. It increasingly saw stateowned housing companies as a way to make profit and improve the state's budget. The abandonment of the principle of the common public interest not only enabled Berlin's government to privatise state-owned housing (see chapter 5), but also allowed it to merge state-owned housing companies.

\footnotetext{
${ }^{100}$ Non-profit housing companies are here referred to as housing companies that were acting under the law of the common public interest (Wohnungsgemeinnützigkeitsgesetz) enforced starting in 1940, but rooted, however, in the long tradition of co-operatives promoting social reformation dating back to the late $19^{\text {th }}$ century. The Nazi Regime integrated the co-operatives as institutions of state-run housing politics. After the Second World War, these state-owned housing companies played a major role in the provision of housing (Rudolph-Cleff 1996). There were however also other owners of non-profit housing companies. In 1990 there were 1850 housing companies following the principle of the common public interest in Germany, owned by such diverse groups as the national and regional states, cooperatives, the church, and unionised companies (Stimpel 1990).

${ }^{101}$ The abandonment of the status of non-profit housing companies was part of a tax reform. With the expected tax income from the non-profit housing companies, the national government aimed to balance out tax benefits it made to other interest groups. The government argued that around 60 percent of the non-profit housing companies were in state-ownership and therefore protected from increasing rent levels by the state. See Stimpel (1990) for a more detailed analysis of the national government's deregulation of non-profit housing companies.
} 
From the mid-1990s onwards, before privatising the first state-owned housing company, Berlin's government started to merge state-owned housing companies with each other. The process was the following: One state-owned housing company raised enough capital to purchase another one, or - as in the majority of the time - two other ones. Berlin's government then received the proceeds of this 'internal sale' and could decrease its own debt without loosing the housing stock. Eleven housing companies were sold in this way until 2002. At the end of 2008, after the privatisation process (see chapter 5) and the mergers, Berlin owned a remaining six housing companies with 15.8 percent of the city's housing stock (Investitionsbank Berlin 2010). ${ }^{102}$

Aside from the proceeds of privatising the two housing companies (see chapter 5), Berlin's government received 1.5 billion Euros from the state-owned housing companies between 1991 and 2006. These incomes were generated through the above described mergers, dividend payments, special dividends from property sales, and subsidy repayments (Wowereit and Junge-Reyer 2007). The payments to the state created increasing financial difficulties for the state-owned housing companies. The representative of the housing department of a district confirmed this process:

"We have experienced how state-owned housing companies were merged. Berlin's government, as the owner, decided to sell some of its housing companies to others in order to receive the revenue from the sale. This meant that the money went from one pocket into another. In the end, this resulted in a situation where some of the state-owned housing companies became nearly bankrupt." (Deputy head of a district housing administration, ID 17)

The payments of the state-owned housing companies to the state are in stark contrast with the expectation that public-led housing is non-profit oriented. This underlines a more differentiated picture from the normalised expectations of a private versus public mode of housing provision. In 2007, this particular form of public-led housing provision, which aims at generating profits for the state while continuing to provide housing for a broad representation of the population, was re-emphasised with the master plan for the remaining state-owned housing companies. The next section analyses the particularities of Berlin's strategic aims in the master plan for the remaining stateowned housing companies.

\footnotetext{
${ }^{102}$ In 2007, the government decided to hold on to approximately 15 percent of its housing stock and stopped further privatisation although single units and smaller estates could still be sold, especially if they fostered owner-occupation (Wowereit and Junge-Reyer 2007).
} 
The government of Berlin does not intervene in the operations of its state-owned housing companies. However, the government is able to influence the strategic orientation of the state-owned housing companies through different channels, thereby implementing political priorities regarding the provision of housing. At least one member of the Senate Department for Urban Development and one member of the Senate Department for Finance participate on each company's administrative board. This facilitates regular information exchange. More important, the government of Berlin annually develops an agreement with each company, outlining the strategic goals; and the state-owned housing companies have to provide quarterly reports. The representative of the Senate Department of Urban Development explained the relation between the state and the companies:

"Let's say we are not influencing the operations. However, we try to provide certain general regulations. From my point of view, these regulations could still be a bit more differentiated and precise than they are now, but of course we do not intervene in the operations." (Employee Senate Department for Urban Development, ID 5)

In 2006, due to the continuing financial difficulties faced by state-owned housing companies - in the form of high debts as a result of the payments that were made to the state (see above), but also because of increasing public opposition towards further privatisation - politicians demanded a master plan outlining the state's general strategy towards its state-owned housing companies (Abgeordnetenhaus Berlin 2006). In the summer 2007, the Senate thus enacted its first master plan to guide state-owned housing companies (see Wowereit and Junge-Reyer 2007). In this strategic plan, there was a commitment to keep the six remaining housing companies under state ownership, with adherence to keeping 15 percent of Berlin's housing stock. Smaller portfolio sales were possible but had to be agreed upon by the Senate. Privatisation to tenants were still to encouraged (Wowereit and Junge-Reyer 2007: 8).

The master plan re-emphasised the state-owned housing companies' mandate to maintain and provide housing for a broad cross-section of the population and to contribute to a stabilisation of rent levels (Wowereit and Junge-Reyer 2007: 6). Berlin's stateowned housing companies were to take into account the tenants' situation when increasing rent levels and to maintain comparable rents after modernisation (Wowereit and Junge-Reyer 2007: 11). Additionally, the strategic plan mentioned the importance of state-owned housing stock for accommodating people unable to access the private housing market. State-owned housing companies therefore had to integrate socially disadvantaged people. Furthermore, they were considered important partners for the positive development of disadvantaged neighbourhoods (Wowereit and Junge-Reyer 2007: 7); for example, contributing to neighbourhood management programmes, 
which aim to "activate the commitment of residents" (Senatsverwaltung für Stadtentwicklung 2007a: 1, author's translation).

The master plan therefore confirmed the social responsibilities of state-owned housing companies. In contrast to the traditional aim of state-led housing provision, the master plan newly incorporated economic goals such as profit-making in order to be able to pay dividends to the state. The master plan thus not only depicted the social responsibilities of these housing companies, but also identified economic goals that they had to pursue. The plan outlined the continuation of financial stabilisation in terms of optimising the core business and further reducing the debt (Wowereit and Junge-Reyer 2007: 9). These measures would allow companies to pay out dividends in the future: "The task of state-owned housing companies, today, is to strategically align the company with the political aims for urban development. They need to become economically healthy companies, in order to be able to pay dividends to the state"103 (Wowereit and Junge-Reyer 2007: 5, author's translation). A representative from the Senate Department for Urban Development confirmed the state's aim to lead its housing companies into profit-making enterprises in order to extract dividends:

"I don't think that privatisation was the decisive reason for the professionalisation of Berlin's state-owned housing companies. Moreover, because of the general situation, the Senate took care that the stateowned housing companies are managed more professionally in order to avoid losses and to finally lead the companies into a profit zone. This was done with the intention to siphon dividends in order to improve Berlin's state budget." (Employee Senate Department of Urban Development, ID 5)

Besides social and economic goals, state-owned housing companies were also asked to continue playing a role as vanguards for housing innovation: They were to improve housing with regards to energy efficiency; provide adequate housing for a growing ageing population by re-modelling dwellings for the purpose of communal living.

The master plan left all state-owned housing companies with three responsibilities: Becoming economically viable, remaining socially responsible to a broad crosssection of the population, and being a role model for innovative (and sustainable) investment in the housing sector. Duvigneau (2001: 1, author's translation), a stateowned housing company director prior to the company's privatisation, described this transition of state-owned housing companies as from "a means of redistributional

\footnotetext{
${ }^{103}$ In Annex 6 of the plan, where short, middle and long-term goals for each company are formulated, the economic aims are more detailed. The Senate demands a reduction of the companies' staff, and a further privatisation of dwellings to tenants in order to increase the rate of owner-occupied housing. The companies need to achieve an adequate profit for the state (Wowereit and Junge-Reyer 2007: VIIIXXIV).
} 
politics to an economically successful service enterprise with social standards". These new strategic goals confirm the move to a more entrepreneurial housing provision: For the state, achieving economic goals is equally important as providing housing for a broad stratum of the population. The state no longer perceives the construction and management of housing as a necessary instrument to support low income households, but increasingly uses state-owned housing as a way to raise money.

This vision of state-led housing provision contradicts the understanding of the entrepreneurial city as the mere withdrawal of the state from welfare provision through privatisation. The reformation of state-owned housing companies shows that a transformation towards an entrepreneurial housing provision is more complex than the retreat of the state in favour of private agencies. In contrast to the privatisation of state-owned housing (see chapter 5), the reformation of the state-owned housing companies promotes the integration of market mechanisms into the state-led housing provision (compare Fosler 1992; Jessop 1997b). In Berlin, these market mechanisms are identified as the integration of economic goals into public-led housing provision.

The integration of market mechanisms into the state-led housing provision further challenges the dualistic understanding of the state versus the private sphere of housing provision. This creates a particular hybrid form of public-led housing provision which cannot simply be equated to a private-led form of provision. In the previous chapter, it was shown that the private sphere of housing provision is not one dimensional, but is instantiated in particular production mechanisms. Equally, the incorporation of profitoriented goals into state-led housing provision does not mean that state-owned housing companies are part of the private sphere of housing provision. While integrating economic goals, state-owned housing companies still have a political mandate to provide housing for a broad cross-section of the population, and especially for low income households. To this end, the chapter turns its attention to an analysis of how state-owned housing companies actually implemented their new mandate, ultimately creating processes of uneven development.

The master plan's economic and social guiding principles shape the state-owned housing companies production mechanisms in particular ways. In order to understand how this form of entrepreneurial housing provision creates mechanisms of uneven development, it is important to analyse the production mechanisms of state-owned housing companies. The state-owned housing companies' production mechanisms are however not solely dependent on the state's guiding principles; their strategies are also highly influenced by Berlin's specific market conditions in which they have to operate. Before investigating the contingently emerging production mechanisms of state-owned housing companies, the following section analyses Berlin's market con- 
ditions and how they have changed resulting from the entrance of institutional investors.

\subsection{Institutional Investors Created Competitive Market Conditions}

Until 1990, competition between state-owned housing companies was sparse. The relation among the state-owned housing companies was more collaborative than competitive due to three mechanisms: First, state-owned housing companies, as all other non-profit housing companies, were regulated in the particular way described above, where their profits were limited and activities were constrained to social housing and certain segments of the private housing sector. Second, there was a widespread housing shortage in Berlin before and shortly after reunification (see chapter 1 and 4). State-owned housing companies did not have to compete for tenants. Third, stateowned housing companies dominated certain neighbourhoods due to their historical development where each housing company was mandated to construct and manage particular housing estates. The state-owned housing companies' activities were therefore spatially concentrated, giving them a monopoly position in certain neighbourhoods.

This non-competitive situation however changed with the transformation of these conditions: First, the reformation of state-owned housing companies triggered profit expectations (see section 6.1) which fostered a rivalry, defined through their profits, amongst themselves. They each had to broaden their activities in order to generate the expected profit and therefore they competed for profitable investment opportunities. This competition was reinforced through a public debate on the state-owned companies' value; and whether their selling price values more than their economic, social, and environmental contribution to Berlin's development. This debate was connected to the question of whether more state-owned housing companies should be sold and if so, which ones. A representative from a state-owned housing company explained:

"It is certainly the case, if you consider all the state-owned housing companies, that the possible profits through privatisation were discussed. [...] Hence, what can the state-owned housing companies do? They have to make profit, to be cost-effective and they have to place themselves differently on the market. They belong to Berlin and the Senator for Finance is looking at what he can take out of them to help a city that chronically suffers from financial difficulties. Thus, you are no longer just a landlord, but you develop; you brand yourself and you position yourself in the market. This is due to the fact that there are competing [state-owned] companies that have a certain quality, revenue optimisation, and customer proximity that the private housing companies do not provide." (Deputy head of a customer service centre for a state-owned housing company, ID 24) 
Second, the surplus of housing that Berlin had starting in the mid-1990s created a more competitive market situation for housing providers. In order to keep the income stream stable, housing companies were forced to fight vacancy rates by attracting more tenants. A representative of a state-owned housing company confirmed this, underlining the competition between private and state-owned as well as among stateowned housing companies:

"The competition is of course strong, also between state-owned housing companies. I don't really care if I get a tenant from another stateowned company or a privatised one; the main point is that the tenant lives with us, is reliable, takes care of his apartment and the environment, and adheres to the rules." (Technical project manager of a state-owned housing company, ID 20)

And third, the entrance of institutional investors (see chapter 5) drastically changed the ownership structure of housing provision, creating a more competitive environment for the remaining state-owned housing companies. Institutional investors abrogated the monopolistic position of state-owned housing companies in certain areas. Investment funds bought previously state-owned housing, competing in the same market segment. The deputy director of a tenant association pointed to the difficult position that state-owned housing companies are in today:

"Berlin's state-owned housing companies are in a difficult situation from my point of view. They are under political pressure to provide housing for the financially disadvantaged population. At the same time, they are in competition with the new investors. Previously, they were not really in competition with the private landlord who owned eight apartments. However, they are in competition with the new investors because they have the same structure and try to attract the same tenants." (Deputy manager of an umbrella tenant association, ID 6)

In this more competitive market environment with a diversified owner structure, the activities of state-owned housing companies were no longer protected and they had to adapt to the new provision structure.

Thus far, the chapter established the state's changing aims of maintaining control of state-owned housing companies. The new guiding principles for the state-owned housing companies' social, economic, and innovative responsibilities were outlined. The chapter further analysed the specific market conditions under which state-owned housing companies acted. Having established these conditions, the chapter now turns to an analysis of the contingently emerging production mechanisms of state-owned housing companies, investigating how these contribute to processes of uneven development. 


\subsection{Guiding Principles and Competitive Market Conditions Shaped the Strategies of State-owned Housing Companies}

Thus far, the chapter explored the redefinition of state-led housing provision and the particular market conditions within which state-owned housing companies operate. In order to explain how the reformation of state-owned housing companies generates processes of uneven development, the chapter now turns to an investigation of the contingently emerging production mechanisms within the context analysed. The guiding questions for the analysis of how production mechanisms fostered uneven development were therefore as followed:

- How do the production mechanisms of the state-owned housing companies play out in practice under the competitive market conditions?

- How do the production mechanisms of state-owned housing companies affect the consumption under the competitive market conditions?

The following sections analyse the finance, investment, management, and exchange strategies of state-owned housing companies under Berlin's specific market conditions, investigating how the particular strategies affect the consumption of stateowned housing. The analysis is predominantly based on three out of the six stateowned housing companies.

\subsubsection{Finance of State-owned Housing Companies}

Even though Berlin's government introduced economic goals into the guiding principles of state-owned housing companies, the financial mechanisms differ considerably from both types of investment funds, the value added and the opportunistic, analysed in the previous chapter. First, the financial preconditions of state-owned housing companies differ largely from real estate private equity funds. Managers of real estate private equity funds collect capital for a specific investment project (see section 5.3) which they exit as soon as the return on investment is realised. State-owned housing companies, being public limited companies (AG) or companies of limited liability $(\mathrm{GmbH})$, cannot enter and exit Berlin's housing market as they please. They are permanent actors in Berlin's housing market, carrying historically developed financial preconditions with them (see below). This means, they have to integrate much longer time spans into their strategies, even compared to long-term investors such as value added investment funds. As a result, state-owned housing companies are highly dependent on steady income from the provision of housing.

Second, in comparison to the institutional investors' profit expectations of 11 to 15 percent for value added funds and 16 percent or more for opportunistic funds, the state's profit expectations are lower. There is no official number, but a former parlia- 
mentarian claimed that the Senator for Finance had expected five percent. Although profit expectations were lower, the state required state-owned housing companies to increase their equity rates (see Table 6.1). In order to reduce debt and increase their equity rates, state-owned housing companies had to make high profit rates. Only through high profits, were they able to fulfil both expectations; increasing equity rates and pay out dividends. Again, this was achieved through increasing income streams. Third, state-owned housing companies were not only structured through these finance mechanisms, but were further structured through the social and innovative guiding principles of the state (see section 6.1) such as the mandate to provide housing for low income households. In contrast to the private real estate equity funds, state-owned housing companies had to generate higher incomes in order to carry out these social responsibilities (Duvigneau 2001: 8).

All of the remaining state-owned housing companies acted under these finance mechanisms. They had to reduce their debts and increase their income streams in order to meet the terms of their owner, the government of Berlin. However, each state-owned housing company's specific condition differed based on its historical development. The following paragraph analyses how the state-owned housing companies differed in regards to their financial situation and portfolio structure.

\section{Different financial preconditions for state-owned housing companies}

Historically, state-owned housing companies operated in specific areas of the city. This geographical distribution influenced their wealth. Their position was however reconstituted after merging with other housing companies (see section 6.1). The acquiring company ended up with greater or lesser amounts of debt, depending on the financial condition of the state-owned housing company that was bought. Moreover, the post-merger financial situation of the state-owned housing company also depended on the housing portfolio of the acquired companies. The state-owned housing company that could acquire another one which owned a considerable amount of $19^{\text {th }}$ century block developments for which demand was relatively high, ended up in a better position compared to a state-owned housing company that had to acquire one which predominantly owned prefabricated housing estates in the outskirts. A stateowned housing company project manager explained the acquisitions they made and the financial situation they were put in:

"In 2000, we made an acquisition of two other state-owned housing companies. One of the companies had exclusively old housing units in Prenzlauer Berg, around 13,000 units I think. The other company was in a catastrophic situation necessitating major repairs and maintenance to its housing stock. We also had to modernise the acquired company's housing stock and make it cost-effective again. This acquisi- 
tion therefore had an extreme impact on the finances of our company."

(Technical project manager of a state-owned housing company, ID 20)

The 2003 annual report of another state-owned housing company described the effect of the shrinking population on its business operations, explaining how the shrinkage unevenly affected its housing stock. The housing stock it owned historically was only marginally affected because it was distributed all over the city and contained housing from all time periods. However, the housing stock it acquired from a company in East Berlin with almost exclusively prefabricated housing built between 1980 and 1985 in the outskirts was dramatically affected (Senatsverwaltung für Finanzen 2004b: 223). Table 6.1 shows the equity and vacancy rates of the three state-owned housing companies analysed, indicating their economic position in terms of equity and vacancy rates in 2002 after the mergers were completed, and in 2009, respectively.

Table 6.1: Economic Position of State-owned Housing Companies Analysed

\begin{tabular}{|c|c|c|c|c|}
\hline & \multicolumn{2}{|c|}{ Equity rates } & \multicolumn{2}{|c|}{ Vacancy rates } \\
\hline & 2002 & 2009 & 2002 & 2009 \\
\hline Company A & $14 \%$ & $19 \%$ & No data & $5.0 \%$ \\
\hline Company B & $2 \%$ & $7 \%$ & $3.5 \%$ & $3.5 \%$ \\
\hline Company C & $14 \%$ & $25 \%$ & $8.9 \%$ & $5.8 \%$ \\
\hline
\end{tabular}

Source: Senatsverwaltung für Finanzen (2004b) and Senatsverwaltung für Finanzen (2010b).

The analysis shows that the financial situation of state-owned housing companies was uneven, creating different conditions under which they had to comply with the economic and social goals mandated by Berlin's government. This underlines the argument that state-led housing provision takes different forms and cannot be abstracted as such. Moreover, it points to the need to take both the finance mechanisms and the differing pre-conditions into account (see also section 6.3.3).

Having established the financial mechanisms of state-owned housing companies and their differing conditions, the following section analyses the contingently emerging investment, management, and exchange strategies of state-owned housing companies.

\subsubsection{Investment, Management, and Exchange of State-owned Housing Companies}

The finance mechanisms established in the last section show that state-owned housing companies became highly dependent on income streams. Due to the depressed market situation where rent levels cannot be increased arbitrarily, the logic consequence for state-owned housing companies would have been that - similar to the value added investment funds - they would have focused on the housing stock with development potential, modernised it and increased rent levels, improving the social structure of 
tenants. Compared to value added investment funds, state-owned housing companies have however a mandate to provide and maintain housing for low income households. This created specific investment, management, and exchange mechanisms. This section explores the strategies observed among state-owned housing companies.

\section{Increasing income streams through selling unprofitable housing estates}

In order to pay dividends to Berlin's government (see section 6.1), state-owned housing companies took up credit capital to buy the other state-owned housing companies. This affected their equity structure because they faced increasing interest payments and reduced liquidity often resulting in precarious financial situations which forced them to consolidate their budgets and reduce their debt. In order to increase their equity rates as required by Berlin's government, state-owned housing companies sold a portion of their properties (see section 5.1).

All state-owned housing companies followed this divestment strategy. The government's imperative was to sell 15 percent of the state-owned housing stock (see chapter 5). State-owned housing companies tried to divest properties that were not deemed good investment opportunities and that would not create demand. The managing director of a state-owned housing company emphasised the company's survival strategy and pointed to the fact that the housing required renovation:

"The housing estate needed between 35 to 45 million Euros in renovation. The estate was characterised by a difficult social structure and a vacancy rate of 15 percent. It was necessary for our company to sell it, we would have had no chance otherwise." (Managing director of a state-owned housing company, ID 28)

State-owned housing companies predominantly sold the housing stock with the most problematic physical and social conditions. Similarly to value added investment funds, state-owned housing companies divested housing without development potential as much as possible. If they were in a financial position to acquire new housing, they invested in housing with better profit margins. The representative of the Senate Department for Urban Development confirmed this strategy:

"There is also the tendency that state-owned housing companies acquire housing again. Certain estates, I say, where for example the modernising and maintenance costs are very high, they are naturally going to be tried to be divested. Other housing estates are acquired which can be further developed. There is a lot of movement." (Employee Senate Department for Urban Development, ID 5)

In 2007, the state stopped the privatisation of state-owned housing. State-owned housing companies could therefore no longer divest the housing without development potential as easily as during the height of the privatisation phase. Instead, now they had 
to get approval from Berlin's government for each en bloc privatisation. State-owned housing companies were therefore constrained in the housing divestment process for political reasons and not, as in the case of private investors, due to financial market failures (see section 5.3.3).

In comparison to value added investment funds that could cherry-pick the portfolios they acquired, state-owned housing companies still have housing without development potential. In this regard they are closer to value added investment funds that took over whole companies and were left with some housing that did not have development potential (see section 5.4.2). However, unlike value added investment funds which neglected the housing without development potential when divestment was not possible - state-owned housing companies were under closer political control and could not completely abandon their unprofitable housing estates. The next sections analyse how state-owned housing companies dealt with the imperative to create income aside from selling complete housing estates and provide good housing standards for a broad cross-section of the population.

\section{Creating profit and providing low income housing through investing selectively}

State-owned housing companies have a high amount of housing units in large-scale housing estates at the edge of the city (see chapter 4 ). These estates are normally not regarded as housing with development potential. In contrast to the investment funds that neglected the housing without development potential, state-owned housing companies did invest and upgrade less popular housing stock such as the post-war highrise developments located in the outskirts. Thus, while the investment fund did not invest at all in its large-scale apartment blocks, the state-owned housing company improved and painted their buildings' façade within the same housing estate. Complete modernisation of the buildings did however also not happen under the ownership of the state-owned housing company. A tenant consultant compared the privatised and state-owned housing company's investment strategy in the large-scale housing estate he has been working in:

"The privatised housing company has not invested anything into the buildings since I am there. The state-owned housing company has at least renovated the façade of the building, but basically they just painted the façade; it was not a full renovation." (Collaborator of a tenant consulting service, ID 21)

State-owned housing companies invested highly selectively, adapting the quality of modernisation to a certain housing type according to its potential to create demand and ultimately increase rents. State-owned housing companies strategically invested to provide housing at different rent levels: While continuing to invest in all housing types, they prioritised investment into housing with development potential and mini- 
mally renovated properties where profits could not be achieved due to the depressed market situation. A technical project manager from a state-owned housing company underlined the necessity for this prioritisation:

"The solution is to reduce the housing standard, to no longer spoil the tenants, but also to explain to the tenants that there is no money for it. This is possible. There are ways to renovate cheaply. The message is simple; we have to tighten our belts. We cannot make every repair you wish for. At the same time, you have to optimise your core business where there are good chances in the long-term to make profit: You have to chose the housing with good chances for development to invest in and wait to invest in the other ones with the hope that maybe one day the state has money again to subsidise housing." (Technical project manager of a state-owned housing company, ID 20)

This selective investment strategy was also applied within a single apartment building. A state-owned housing company renovated a high-rise development in one of the large-scale housing estates of the post-war period in the periphery of the city. The state-owned housing company modernised the five top floors apartments to luxurious standards while renovating the apartments without a view according to lower standards. The representative of the state-owned housing company explained:

"This is the first time we deployed an entrepreneurial housing concept that we developed ourselves. With this concept, the idea came up to renovate the five top floor apartments based on a high standard, but also with high rents because it is cool to live there and to have a view over the city. We try to attract a clientele who is willing to pay 6 to 6.20 Euros per square meter. The lower floor apartments will be cheaper in terms of rent levels, but also in regards to the quality of renovation." (Head of a customer service centre for a state-owned housing company, ID 24)

This selective investment strategy illustrates the balance between the pressure to make profits, thus being entrepreneurial, and provide housing for lower-income households. The state-owned housing companies tried to create a demand for better off incoming tenants. The top floor apartments were renovated without taking into account the existing tenants' financial situation. The apartments were vacated and existing tenants were not able to move back into the renovated unit because rent levels were too high. At the same time, the state-owned housing company complied with the mandate to provide housing for lower-income households, renovating the bottom floors according to a lower standard. The representative was also highly aware of the government's mandate to hold onto low income housing:

"The task of our company, which is determined by the government, is to hold onto low income housing. We cannot completely move away from this market segment and solely focus on the higher-priced mar- 
ket segment." (Head of a customer service centre for a state-owned housing company, ID 24)

In order to hold on to low income housing, state-owned housing companies tried to make profits in the higher market segments and make the best of the housing they had in the lower market segments. This selective investment strategy starkly contrasts with the normalised conceptualisation of state-led housing provision that provides equal housing standards to everyone in need. Moreover, this investment strategy underlines the hybrid form of state-led housing provision which seeks to strike a balance between economic and social goals.

State-owned housing companies however not only strategically invested in their housing stock, they also reduced personnel and maintenance in order to save costs and generate more income. The next section explores these management mechanisms.

\section{Saving costs through reducing personnel and maintenance of housing}

After the different state-owned housing companies' mergers were completed at the end of 2002 (see section 6.1), the remaining state-owned housing companies began to streamline their organisation reducing personnel to consolidate their budgets. This affected the maintenance of the housing. The state-owned housing companies differ very little from value added investment funds in this regard. While both types of actors provided a certain standard to keep tenants (see section 5.4.2), state-owned housing companies and value added investment funds saved costs by lowering maintenance standards.

All analysed companies reduced personnel. This indicates that the ratio between the number of employees and the amount of housing they managed had increased. A respondent confirmed the reduction in employees and explained it with the high debt that had to be reduced after the acquisition of other state-owned housing companies:

"I think we paid 270 million Euros for the two others state-owned housing companies we bought. This money went to the state of Berlin. [...] When the state had to extract that money, it meant we had to save it. [...] We also considerably reduced personnel through retirement or compensation packages." (Technical project manager of a state-owned housing company, ID 20)

Table 6.2 shows the reduction of personnel in comparison to the reduction of the housing stock. Except for one of the state-owned housing companies analysed, the reduction of the number of employees was considerably higher than the reduction of properties. 
Table 6.2: Reduction of Personnel in Comparison to Reduction of Housing

\begin{tabular}{|l|r|r|}
\hline & $\begin{array}{l}\text { Reduction of personnel be- } \\
\text { tween 2003 and 2009 in \% }\end{array}$ & $\begin{array}{l}\text { Reduction of housing stock } \\
\text { between 2003 and 2009 in \% }\end{array}$ \\
\hline Company A & $-36 \%$ & $-26 \%$ \\
\hline Company B & $-4 \%$ & $-15 \%$ \\
\hline Company C & $-34 \%$ & $-13 \%$ \\
\hline
\end{tabular}

Source: Based on Senatsverwaltung für Finanzen (2004a), Senatsverwaltung für Finanzen (Senatsverwaltung für Finanzen 2010a), Senatsverwaltung für Finanzen (2004b), and Senatsverwaltung für Finanzen (Senatsverwaltung für Finanzen 2010b).

Table 6.2 however also shows that there are considerable differences between the three state-owned housing companies analysed. These variations point to the fact that state-owned housing companies possibly differentiated in the way they dealt with the state's economic and social requirements. A possible explanation for this is the uneven financial preconditions faced by state-owned housing companies mentioned above (see section 6.3.1). One respondent also claimed that it highly depended on the management team in charge of the company and the strategy it followed. The fact that state-owned housing companies had different approaches to housing provision (see also section 6.3.3 where this is further discussed) despite having the same owner and the same finance mechanisms was an unexpected outcome not previously conceptualised (see section 8.5 for a discussion of integrating this point into future research).

Independent of the reasons for the difference in reducing personnel, this move also affected the management of the properties, influencing the physical outcome of the housing provision. In comparison to the value added investment funds, service centres were still operating. Housekeeping however, deteriorated. The tenant consultant of a $19^{\text {th }}$-century block developments neighbourhood complained about the state-owned housing company's management of the housing stock:

"The state-owned housing company asked as much as possible for rent. And since the neighbourhood is popular, what they ask for is nowadays quite a lot. At the same time, they invest as little as possible into the maintenance of the housing. [...] The housekeeping work such as cleaning and gardening is also reduced." (Collaborator of a tenant consulting service, ID 19)

The rationale behind these cost-saving strategies point to a more entrepreneurial housing provision. The state-owned housing companies reduce their investment because of the government's prerogative to extract dividends. The income from housing provision and management is no longer necessarily re-invested in the housing stock, but is a profit-making endeavour. This more entrepreneurial rationale for state-led housing 
provision does however not yet explain the uneven processes it creates. Instead, the way state-owned housing companies applied cost-saving strategies selectively is key to understanding uneven processes. The analysis shows that state-owned housing companies invested and saved costs in an uneven way, depending on the housing type and the possibility of making a profit with the particular unit or not. Moreover, the analysis points to the fact that the state-owned housing companies played out differently, therefore generating processes of uneven development.

Having established the state-owned housing companies' investment and management strategies, the following sections turn to the exchange strategies undertaken by them. In order to create income in a relatively depressed market situation, especially in the large-scale housing estates located in the periphery, state-owned housing companies had to find a balance between lowering vacancy rates and increasing rent levels. As analysed above, state-owned housing companies also invested in housing with less development potential, albeit selectively. They however also actively sought clients in order to decrease vacancy rates without compromising rent levels.

\section{Attracting tenants through creating niche markets and branding}

Due to a more competitive market (see section 6.2), but also because of the depressed market situation in the post-war high-rise developments, state-owned housing companies increasingly sought to improve their competitive advantage and attract tenants through the creation of niche markets. State-owned housing companies were targeting specific tenant groups such as students, and promoted themselves as leaders in energy efficient housing to attract the conscious consumer. A deputy manager of an umbrella tenant organisation confirmed the repositioning of state-owned housing companies in certain market segments:

"There is the tendency of state-owned housing companies to occupy certain subjects in order to gain a reputation. For example, there are companies that are concerned with the question of housing for senior citizens. Or there are others that are occupied with the question how to make housing energy-efficient and how to use renewable energies." (Deputy manager of an umbrella tenant association, ID 6)

While reducing maintenance and management costs, state-owned housing companies put considerable effort into advertising. With a new image intended to set them apart from their competitors (both state-owned and private housing companies), stateowned housing companies attempted to attract and retain tenants. A representative of a state-owned housing company explained the attempt to brand itself:

"We have a new logo and started an image campaign with posters all over the city. This is an attempt to establish the brand of our company. We are not sure if we achieve this goal because we can only do it 
within Berlin and not throughout Germany. But the idea is that people in Berlin know the name of our company." (Head of a customer service centre for a state-owned housing company, ID 24)

The state-owned housing companies also stopped publishing their common trade magazine and began publishing their own. Every individual company increased its investment in marketing.

"They increase their efforts for attracting and retaining clients; they all publish their own magazine now, whereas they previously had a common one. Apparently, they could not present themselves well enough to distinguish themselves from each other." (Deputy manager of an umbrella tenant association, ID 6)

The strategy of attracting tenants to reduce vacancy rates stood in stark contrast to opportunistic investment funds that lowered rent levels to seek more tenants. Stateowned housing companies were highly dependent on income streams, and could not compromise on rent levels. They had to seek tenants with other strategies, such as development investment, creation of niche markets, and branding. This allowed them to decrease vacancy rates and increase rent levels at the same time.

Undertaking branding campaigns and its search for niche markets suggests that the state no longer provides housing opportunities in relatively equal standards with equal rent levels. Housing has become a commodity that is customised and advertised to different target groups. State-owned housing companies make the consumer believe that being their tenant differentiates them from others. This starkly contrasts with an understanding of state-led housing as a decommodified form of provision that is socially financed, standardised, and allocated. Commodification of state-led housing also took place by raising rent levels in all market segments and abandoning the principle of quasi-social housing, analysed in the next section.

\section{Increasing income through raising rent levels to the maximum amount possible}

To generate more rental income, state-owned housing companies pushed rent levels to the maximum amount possible. They acted equally aggressively as value added investment funds to achieve high profits (see section 5.4.2), ultimately displacing tenants. This especially affected tenants in modernised housing units of $19^{\text {th }}$-century block developments, where demand was high, but also in luxuriously modernised top floor apartments located in the outskirts as analysed above. However, state-owned housing companies also increased rent levels in the lower market segments.

Highly dependent on income streams, state-owned housing companies increased rent levels to the maximum amount possible in all market segments. In comparison to opportunistic funds that completely neglected their housing (see section 0 ), state-owned 
housing companies maintained the housing stock relatively well. With the creation of niche markets and branding efforts, state-owned housing companies were able to attract clientele and increase rent levels. A representative of a state-owned housing company explained their rent strategy that clearly pushed rent levels as high as possible.

"The decisive point is the location. In the Köpenik area, we clearly have high-priced housing because the location is near the water. There you can get six Euros per square metre in smaller apartments. In certain areas, we work with seven to eight Euros because of the location, and the clientele that demands this kind of housing is ready to pay a lot of money for living in a trendy old apartment under heritage protection a little further away from the centre. However, Köpenik also has other areas with two to three storeys and where we can take 5.50 or 6.50 [Euros]. In large housing estates, 5.50 Euros is however already the maximum we can take." (Head of a customer service centre for a state-owned housing company, ID 24)

The state-owned housing companies' year end reports that were analysed, further confirmed that rent increases were implemented wherever the market situation allowed it (Senatsverwaltung für Finanzen 2010b). ${ }^{104}$

The turn towards extracting the maximum possible rents contradicts with what Droste and Knorr-Siedow (2007) call 'quasi social' housing (see also Stephens et al. 2008). According to these authors, state-owned housing companies traditionally rented their free market rental units at below market rates to fulfil their social mandate. Profit maximisation was not sought in favour of social benefits such as low levels of segregation within neighbourhoods or limiting housing allowance expenditure. None of the state-owned housing companies analysed adhered to the provision of 'quasi social' housing. The representative of a state-owned housing company confirmed this and explained what happened when the housing units in a high-rise estate from the late 1970s came on the free market because state subsidies were repaid:

"In this area, 4,300 housing units will come on the free market in January 2010. This means, we will announce a 20 percent rise to our tenants. This is a rise from 3.80 to 4.50 Euros per square metre and yes, it is not clear if the tenants can bear this increase." (Head of a customer service centre for a state-owned housing company, ID 24)

\footnotetext{
${ }^{104}$ Hallenberg's report (2008: 106) also confirmed this. The report stated that state-owned housing companies still owned a larger amount of housing units in lower market segments compared to added value investment funds. The increase of rent levels was however similar to that of the investments funds' housing stock. Between the end of 2004 and 2007, rent levels of state-owned housing companies increased between 7 and 10.5 percent compared to 13 percent by the largest privatised housing company.
} 
Under the new guiding principles (see section 6.1), state-owned housing companies were no longer able to make general concessions reducing their revenue. Due to their social mandate, the state-owned housing companies were however prepared to make temporary compromises for tenants with financial difficulties. Their exchange strategy ended up insisting on increasing rent levels, but did not force tenants who were not able to pay out immediately. Under exceptional circumstances, state-owned housing companies, compared to value added investment funds, were willing to make concessions on their profit-making. A representative of a state-owned housing company claimed that they would still act in a socially responsible manner, prepared to negotiate individual cases of hardship:

"Today, in order to maximise profits, we exhaust all legal possibilities. That sometimes hurts because long-term tenants can no longer bear the rents. However, we can of course also help; we can look for another apartment that might not be 100 square metres, but 65 to 70 square metres for a two-person household. We have lots of possibilities there. And in case of hardship we can also wave the rent increase. However, in these cases we have to be sure that the tenant is really without means and can't pay the rent. And of course, this can only be done as a temporary measure." (Technical project manager of a stateowned housing company, ID 20)

State-owned housing companies could often fall back on their wide ranging housing portfolio and were able to relocate tenants within their own housing stock. A representative of a district administration also confirmed the willingness to negotiate and find individual solutions for socially disadvantaged tenants.

"There are difficult tenants that are just not moving out when there is a renovation announcement. There are several of these cases due to the low rent levels that were common in this neighbourhood before. For these cases, state-owned housing companies are more willing to negotiate." (Collaborator of an urban renewal division within a district administration, ID 18)

The abandonment of quasi-social housing clearly marks a shift from the traditional form of state-led housing provision. The state-owned housing companies' informal means of negotiating single cases distinguishes them from the private-led housing provision analysed in chapter 5 . The openness to negotiate single cases however, does not hide the fact that state-owned housing companies rely on higher rent levels because they have to increase profit margins in order to reduce their debt load and pay dividends. This also affected their tenant allocation strategy. 
When state-owned housing companies modernised the housing stock, they pursued an allocation strategy which prioritised a clientele with a high socio-economic status.

State-owned housing companies were reluctant to allocate their housing to less well off tenants, even when it was still under regulatory control as a result of subsidisation (see chapter 7). A tenant consultant attributed this to the ignorance of certain employees within the housing company:

"They would prefer not to take anyone with a housing voucher, but only tenants that have a higher income. However, this is also because the administrators of the housing companies often don't know that the income limit for a housing voucher is pretty high and people with housing vouchers are not necessarily the most disadvantaged." (Collaborator of a tenant consulting service, ID 21)

In comparison to value added investment funds that openly admitted their discriminating allocation strategies, state-owned housing companies were aware of their political mandate to provide housing for lower-income households. A quote from a representative of a state-owned housing company showed how cautious they were:

"At least we want to keep the social structure as it is now. Of course, we want to improve it a little, but we have to be careful with this subject. We have a mandate from the state to provide affordable housing. And if we say now we don't want to have tenants on social benefits, we naturally can't say it like this because people on social benefits are part of this city. However you can't only take them." (Head of a customer service centre for a state-owned housing company, ID 24)

State-owned housing companies could not openly discriminate tenants. However, by pushing rent levels to the maximum allowable possible, state-owned housing companies still excluded certain household groups from renting a specific unit. Tenants who could not afford higher rent levels after modernisation were allocated to lower quality housing.

The production mechanisms of state-owned housing companies were guided by the government's imperative to lower their debt, increase their equity and profit-making, while continuing to hold housing for low income households. State-owned housing companies complied with these principles by divesting some of their non-profitable housing estates. When the en bloc privatisation of state-owned housing was no longer politically acceptable, state-owned housing companies held onto their portfolio, selectively investing based on expected rental income after modernisation. They restructured, reducing personnel and the quality of maintenance, in addition to undertaking considerable efforts to attract and retain their clientele through the creation of niche markets and branding. At the same time, they increased rent levels according to the 
possibilities within specific market segments. These production mechanisms split the state-owned housing into different market segments.

\section{State-owned housing companies shape a segmented form of consumption}

Based on the production mechanisms analysed above, state-owned housing companies accepted a segmented form of consumption. Selective investment linked to strategic rent increases further augmented tenant segmentation. State-owned housing companies made a clear division between upper and lower market segments. They achieved their economic goals by increasing rent levels to the maximum amount possible and abandoning the principle of quasi-social housing. Because these companies could attract an affluent clientele to the $19^{\text {th }}$-century block developments in inner city areas or in luxuriously renovated apartments further out of the city, they increased rent levels primarily in these housing units. This created a situation where inner city housing became too expensive for low income households.

At the same time, state-owned housing companies complied with the mandate to provide housing for low income households by using the less profitable housing stock in their portfolio. This housing is in the outskirts where vacancy rates are still high and rent levels relatively low. Investment in this housing stock was often not profitable and therefore developed according to lower standards, resulting in the concentration of low income households in these properties. This segmentation, on a neighbourhood or a block scale ${ }^{105}$, starkly contrasts with the traditional form of state-led housing provision that focused on the provision of high quality standardised and often monotonous housing for a broad stratum of the population. Compared to the production mechanisms of value added and opportunistic investment funds, which actively created a concentration of high and low income households respectively, state-owned housing companies created segregation in a more subtle way (compare section 5.4).

Unlike the investment funds analysed in chapter 5, state-owned housing companies adhered to a wide range of housing types. However, the particular way they developed their properties fostered the uneven development of housing and did not counter segregation tendencies. A respondent described this situation:

"With a few social projects, the state-owned companies suggested that everything remained the same. However, especially where they saw market opportunities, state-owned housing companies pressed ahead

\footnotetext{
${ }^{105}$ The segmentation of tenants within one building is comparable to the situation in the $19^{\text {th }}$-century block developments at the beginning of the Twentieth century before the state intervened in the provision of housing structure; low income families lived in the rear wings of the block and higher income families in the front rows of the block (see section 4.1).
} 
to increase rent levels in new tenancy agreements without considering the context of the market. They pushed forward with significantly higher offers, the consequences being that tenants were under pressure. State-owned housing companies were responsible for a development that worsened the situation in many neighbourhoods, leading to more social segregation." (Deputy managing director of an association for housing and urban development, ID 8)

The production mechanisms and their effects on housing consumption analysed above, have been observed among all of the state-owned housing companies studied. As mentioned, differences among state-owned housing companies however existed regarding the extent to which they followed the strategies analysed. These differences are further explored in the next section.

\subsubsection{Differences Among State-owned Housing Companies}

The above-explored strategies have been observed among all three state-owned housing companies analysed. As pointed out, subtle differences between state-owned housing companies however emerged. These differences became especially apparent with regards to the state-owned housing companies' social engagement. This engagement is analysed in more detail, especially how state-owned housing companies' attitudes differed on this subject.

In contrast to employing 'hard' means such as below-market rents (quasi-social housing), the social responsibility mandate of state-owned housing companies increasingly focused on 'soft' means such as supporting neighbourhood improvement. Commitment to urban development beyond housing was not new: State-owned housing companies have a long tradition of taking care of the neighbourhoods they built (Burkhardt 1999). Since 1999, state-owned housing companies have also participated in the 'social city' (Soziale Stadt) national policy programme that is implemented through Berlin's 'neighbourhood management programme' (Quartiersmanagement). This programme aims for resident participation to improve their disadvantaged neighbourhood. Through educational and cultural projects, neighbourhood management teams ${ }^{106}$ are trying to integrate immigrant families, engage young people, or help create businesses in vacant neighbourhood lots. State-owned housing companies are often important partners for neighbourhood managers.

These neighbourhood revitalisation projects continued to be undertaken by all the state-owned housing companies, as opposed to reduced neighbourhood activities by

\footnotetext{
${ }^{106}$ At the time of investigation, there were 33 neighbourhood management teams, usually constituted of social workers from non-governmental organisations.
} 
investment funds (see section 5.4.2). One of the state-owned housing companies analysed chose however to deepen its social engagement with a strategy called "Value Added City" (Stadtrendite) ${ }^{107}$. The Value Added City concept is defined as the added value provided to Berlin's citizens in terms of social, ecological, cultural, and quality of life components of city living. The particular state-owned housing company therefore used a different mechanism to housing provision.

With the Value Added City strategy, the state-owned housing company not only deepened its social engagement, it also attempted to capture and cost out the social side of its 'soft' engagement in the neighbourhood and the city. The housing company explained on its website that "Value Added City allows it to present the success of social engagement in numbers" (Degewo 2011, author's translation). ${ }^{108}$ The representative of a state-owned housing company explained the idea behind the concept:

"In the wake of the privatisation process, the idea of a Value Added City came on the table for the first time. The question was what the shareholder [the state] gets out of these housing companies besides the annual net income. What other profits are there from having these companies? And then it was assessed that these housing companies are participating in lots of other areas in their neighbourhoods and districts and therefore establish a certain added value or so called Value Added City. [The respondent then went on to talk about the diverse projects, from building an association for coaching students to increased security guards, to tenant parties and sport facilities]. These are of course all small things where the question remains how much impact they have. We cannot measure the value. [...] I cannot say that because of this engagement we have rented out so many more apartments." (Head of a customer service centre for a state-owned housing company, ID 24)

In comparison to traditional neighbourhood engagement, the Value Added City strategy is not only used to reinforce the idea of 'soft' means to support the social improvement of neighbourhoods. As the quote underscores, the particular state-owned housing company uses the strategy also to strengthen its competitive position and to attract tenants. This type of engagement is also closely linked to the company's promotional activities aimed at creating higher demand for their housing. A neighbourhood manager described the collaboration with the state-owned housing company and the importance for the company to sell it as their own product:

\footnotetext{
${ }^{107}$ The literal translation of Stadtrendite would be city-yield. However Value Added City was considered more accurate in portraying the concept, which defines the value added to a city's development, which goes beyond a pure economic return.

${ }^{108}$ The particular state-owned housing company mandated the Humboldt University in Berlin to calculate the Value Added City and came up with the following formula: The value added city = (annual net income + expenditures for social engagement + consequential societal revenues) / (deployed capital) (Degewo 2008: 26).
} 
"The state-owned housing company is very active with regards to school development. They contributed some money at the beginning to our educational initiative. Their engagement happens in collaboration with us. This means, we sometimes have a debate whose name is on the promotional material. The state-owned housing company has a high need for recognition, but we can deal with that. At least they have the same goals as we do." (Project director of neighbourhood management team, ID 26)

This Value Added City strategy promoted by one of the state-owned housing companies was however not embraced by all counterparts. One state-owned housing company that was analysed emphasised the goal to decrease debt more than neighbourhood engagement, even though it was still contributing to the traditional neighbourhood management programmes. The director of this state-owned housing company felt threatened by new political demands that state-owned housing companies need to play a role in dealing with the city's social problems. The director explained the company's strategy and how profit maximisation could be mitigated through new political demands that prioritise social over economic goals:

"We will optimise our core business. We have an investment plan until 2018 which is already quite concrete for up to 2013/14 and we restructure the company which is almost done. We have been certified as an ISO9001 company, this is our strategy: Write off debts, optimise the core business and then, if the demand from the political side turns again, and we have to contribute to the making of the city, we need to have the strength for this. With the former Senator of Finance, we could really be entrepreneurial for five years. But this is ending. Since we are more or less financially stabilised, the political demands with regards to rent levels etc. are increasing again. That will be the big conflict in the future. Value Added City, Value Added City. We say though, without financial added value, there is no Value Added City." (Managing director of a state-owned housing company, ID 28)

This state-owned housing company sees the Value Added City strategy not as an opportunity to strengthen its competitive position, but as a constraint to its economic goals. By contrast, the company that applied the Value Added City strategy used it as a tool to strengthen the entrepreneurial goals. The analysis regarding the state-owned housing companies' attitude towards the Value Added City strategy suggests that state-owned housing companies interpret the state's guiding principles differently and do not cohesively adapt to economic and social demands, but adopt different strategies under Berlin's specific market conditions.

This diverging emphasis with regards to their social engagement contradicts the understanding that state-owned housing companies follow equally the same strategies based on the state's economic and social imperatives. As argued, the analysis suggests that the financial condition of a particular state-owned housing company (see section 
6.3.1) plays a role in explaining these differences. Depending on its financial situation, a company has more or less room for manoeuvre to invest in neighbourhood engagement and using this engagement for promotional activities. Other factors that need further exploration such as the specific management structure may also play a role (see also section 8.5).

The analysis of state-owned housing companies confirmed a more entrepreneurial approach through the integration of market mechanisms into state-led housing provision. State-owned housing companies increasingly treated housing as a commodity that is no longer standardised for a broad cross-section of the population, but tailored to different clients. The integration of these market mechanisms represents however not an abandonment of state-led housing provision. I therefore strongly argue against the simplistic dualism of state-led versus private-led housing provision as analytical categories. The analysis shows that a more entrepreneurial state strategy for housing provision does not equal a privatised form of housing provision. Moreover, the specific market mechanisms that were integrated into state-owned housing companies indicate a particular hybrid form of housing provision.

A more entrepreneurial form of state-led housing provision has to be analysed along the production, regulation, and consumption relations within a specific temporal and spatial context to understand the particular processes it creates. In Berlin, state-owned housing companies apply strategies that were also observed among privatised housing companies (compare with chapter 5). The particular way they use entrepreneurial strategies and the degree to which they use them however differ from privatised housing provision. Having explored the privatised housing provision in chapter 5 and the state-owned housing provision in this chapter, the next section turns to a comparative synthesis of the different providers, looking at their key production mechanisms and their effects on the consumption of different types of housing. 


\subsection{Synthesis of Privatised and State-owned Production Mechanisms}

The analysis of the production mechanisms of both privatised and state-owned housing provision showed that there is no clear distinction between either, but there are different hybrid forms. Moreover, the state's transformation towards an entrepreneurial housing provision has to be treated with caution. The privatisation of state-owned housing does not lead to a one-dimensional mechanism, but has multiple consequences based on how housing production plays out in a specific spatial and temporal context. At the same time, the incorporation of entrepreneurial goals into state-owned housing provision does not generate the same production mechanisms as private-led housing; state-owned housing companies still differ from real estate private equity funds. Furthermore, state-owned housing companies chose to respond to the state's economic and social in different ways.

The analysis of the real estate private equity funds (see chapter 5) and the state-owned housing companies (this chapter) shows that the conceptualisation of private versus state-led housing does not satisfactorily explain the multidimensional mechanisms. I therefore argue that a re-conceptualisation of production mechanisms defined as the particular finance strategy to achieve economic (and, for state-owned housing companies, social) goals better explains the uneven mechanisms. The finance strategy based on risk versus profit (investment funds) and entrepreneurial versus social (stateowned housing companies) explains the way these companies invest, manage, and exchange housing. This section provides an overview of the key mechanisms observed among the different privatised and state-led housing companies in the specific circumstances of Berlin's housing market between 1999 and 2009. Table 6.3 summarises the mechanisms of the value added investment fund, the opportunistic investment fund, and the state-owned housing company. 
Table 6.3: Key Production Mechanisms of Privatised and State-owned Housing

\begin{tabular}{|c|c|c|c|}
\hline & Value Added Investment Funds & Opportunistic Investment Funds & State-owned Housing Companies \\
\hline Finance & $\begin{array}{l}\text { Balancing risk versus profit: Capital gain } \\
\text { through use-value of housing }\end{array}$ & $\begin{array}{l}\text { Balancing risk versus profit: Capital gain } \\
\text { through exchange-value of housing }\end{array}$ & $\begin{array}{l}\text { Balancing economic versus social goals: } \\
\text { Capital gain through use-value of housing and } \\
\text { provision of housing for low income tenants }\end{array}$ \\
\hline Investment & $\begin{array}{l}\text { Value added strategy: Cherry-picking and } \\
\text { modernising } 19^{\text {th }} \text {-century block developments } \\
\text { and Twenties and Thirties row developments } \\
\text { in good locations }\end{array}$ & $\begin{array}{l}\text { Bigger-fool strategy: Purchasing cheap, often } \\
\text { low quality, housing (post-war high-rise de- } \\
\text { velopments) in order to re-sell it at a higher } \\
\text { price }\end{array}$ & $\begin{array}{l}\text { Segmented strategy: Adhering to a wide port- } \\
\text { folio (all housing types), but modernising } \\
\text { based on the possibility to raise rents }\end{array}$ \\
\hline Management & $\begin{array}{l}\text { Efficient management: Streamlining manage- } \\
\text { ment of housing stock }\end{array}$ & $\begin{array}{l}\text { Neglecting management: Abandoning man- } \\
\text { agement of the housing stock }\end{array}$ & $\begin{array}{l}\text { Efficient management: Streamlining manage- } \\
\text { ment of housing stock }\end{array}$ \\
\hline Exchange & $\begin{array}{l}\text { Exclusive exchange strategy: Increasing rent } \\
\text { levels and following a discriminating alloca- } \\
\text { tion strategy, selectively choosing affluent } \\
\text { families }\end{array}$ & $\begin{array}{l}\text { Inclusive exchange strategy: Decreasing rent } \\
\text { levels and following an aggressive letting } \\
\text { strategy, attracting low income tenants }\end{array}$ & $\begin{array}{l}\text { Segmented exchange strategy: Increase rent } \\
\text { levels in all market segments, while willing to } \\
\text { negotiate individual solutions }\end{array}$ \\
\hline Consumption & $\begin{array}{l}\text { Exclusive consumption: Low income house- } \\
\text { holds are displaced or prevented from moving } \\
\text { into the housing that was revalorised }\end{array}$ & $\begin{array}{l}\text { Inclusive consumption: Low income house- } \\
\text { holds, often on social welfare, move into the } \\
\text { neglected housing stock }\end{array}$ & $\begin{array}{l}\text { Segmented consumption: Low income house- } \\
\text { holds can no longer afford the rent and are } \\
\text { displaced from the housing in the higher- } \\
\text { market segments }\end{array}$ \\
\hline
\end{tabular}


Value added investment funds followed a comparably lower risk strategy, with higher equity investment and lower profit targets. They predominantly focused on capital gain through the use-value of the housing, and therefore depended on rental income. This finance strategy entailed both investment in housing with development potential and divestment or, if the latter was not possible, neglecting housing with no development potential. The value added funds modernised the housing, sometimes to luxurious standards, in order to place it within a higher market segment and demand higher rent levels. Tenant service was restructured, and neighbourhood engagement was specifically reduced, but the management of the housing was maintained to a relatively high standard. Value added investment funds provided housing for well off people actively displacing and excluding low income households through rental barriers and a discriminating allocation strategy.

Opportunistic investment funds followed a high-risk strategy that targeted high profits with small equity investment through financial leveraging. They were therefore not interested in investing in the housing. They bought cheap housing to resell it at a higher price within a short amount of time. During the time they held on to the housing, they neglected necessary renovations and abandoned maintenance. The housing management personnel was reduced and replaced with unskilled employees. Especially once opportunistic funds could no longer re-sell the housing due to the financial crisis, they chose to lower rent levels in order to decrease vacancy rates and increase income streams, a necessity in order to serve their interest payments. For the same reasons, they followed an aggressive letting strategy, attracting low income households. Better off households moved out of the neglected housing stock. At the same time, low income households, often on social welfare, moved in creating a concentration of socially disadvantaged tenants.

State-owned housing companies were required to make capital gain through the provision of housing. At the same time, they were still restricted through their political mandate to provide housing for low income households. They chose to respond to this political mandate adhering to a wide-ranging portfolio and strategically investing in the housing based on the rents they could expect. Additionally, they were willing to negotiate with difficult tenants to at least temporarily provide relief from higher rent levels. Furthermore, the state-owned housing companies were committed to neighbourhood improvement. However, the pressure to make profits was high and state-owned housing companies replied by maximising rental income and saving management costs. This generated more segregated neighbourhoods because rent levels in neighbourhoods with high de- 
mand were no longer affordable for low income tenants. Low income households therefore moved into lower quality housing, often in the large-scale housing estates in the periphery.

\section{Conclusion}

The reformation process of Berlin's state-owned housing companies did not mark a withdrawal, but rather a transformation of the state's role in housing provision. The economic and social guiding principles for state-owned housing companies showed however that the state's approach towards housing provision had become increasingly entrepreneurial: Market mechanisms have been implemented or were no longer restricted through particular regulation. Again, the analysis shows that one needs to go beyond a mere confirmation of a more entrepreneurial form - as described in section 2.2 - of state-led housing provision to understand the processes of uneven development that it created. To understand these processes, it is crucial to investigate the particular market mechanisms that were integrated and how they played out in practice. The state's new strategic plan put state-owned housing companies in an ambiguous position - between an economic successful, but socially responsible enterprise. The state's guidelines fostered the state-owned housing companies' profit seeking in order to benefit from dividend payments. At the same time, the state adhered to a principle of providing housing for a broad stratum of the population and specifically for low income households. These finance relations influenced the investment, management, and exchange strategies of state-owned housing companies.

The analysis shows that the way state-owned housing companies dealt with the state's principles was uneven in two ways. On the one hand, state-owned housing companies invested and managed the different types of housing in their portfolio unevenly. On the other hand, state-owned housing companies responded differently to the state's economic and social goals, especially with regards to the social commitment. In this way, they provided housing unevenly. The mechanisms analysed in this chapter further contribute to finding empirically grounded explanations on how a more entrepreneurial mode of housing provision generates processes of uneven development and shows that there is more than one mechanism creating uneven development.

Having established the contingently emerging production mechanisms of the different types of housing providers in the previous and current chapter, the next chapter turns towards the state's re-regulation of social housing and urban renewal, addressing the question of how the state further regulates processes of 
uneven development. Social housing and urban renewal housing are two extremes based on their development potential. Social housing is non-profitable because of its restricted rent ceiling. Urban renewal housing is considered a good investment, especially when supported by state subsidies. The re-regulation of supply-side subsidies for social housing and urban renewal is therefore expected to reinforce the uneven production mechanisms explored in this and the previous chapter 5 . The next chapter investigates how the production mechanisms established so far change under these specific regulatory conditions for social and urban renewal housing. 


\section{Abandonment of State Subsidies for Housing}

This chapter turns towards the question of how the state regulates processes of uneven production development, within the particular housing sectors of social and urban renewal housing. The chapter illustrates how the state further contributes and reinforces processes of uneven development through particular regulatory changes of supply-side housing subsidisation. This is the third process identified in Berlin's new mode of housing provision: The abandonment of supplyside subsidies for social and urban renewal housing coupled with deregulation of rent and allocation rules. This chapter examines how specific regulatory conditions of social housing and urban renewal influence the production mechanisms of institutional investors and state-owned housing companies. It is argued that the way the abandonment of state subsidies plays out in practice reinforces the uneven production mechanisms previously established. The following questions guided the analysis of this chapter:

- How do the production mechanisms change under the specific regulatory changes of social housing and urban renewal?

- How do the production mechanisms affect the consumption mechanisms under the specific regulatory changes of social housing and urban renewal?

- How do the production and consumption mechanisms interact with each other creating processes of uneven development?

Supply-side subsidies for the construction and renewal of housing usually include one or all of the following: Construction grants, loans at lower interest rates, payments of the difference between market and below-market interest rates, and payments between market rent and a subsidised rent (Lawson 2006: 69). The supply-side subsidies that Berlin's government granted targeted the reduction of credit necessary for the construction of social housing and the renewal of old housing. However, towards the end of the $1990 \mathrm{~s}$, Berlin's government started to withdraw from any commitment towards the subsidisation of housing due to increasing financial pressure which rendered the government incapable of continuing to run a costly housing subsidies system. ${ }^{109}$

\footnotetext{
${ }^{109}$ See chapter 1 on Berlin's urban development in the 1990s and the resulting financial difficulties.
} 
Two processes resulting from the abandonment of supply-side subsidies can be distinguished: First, the abandonment of supply-side subsidies for social housing and second, the reconfiguration of urban renewal policies. This chapter is therefore divided into two parts. Section 7.1 analyses the mechanisms generated through the abandonment of subsidies for the social housing stock. Section 7.2 explores the mechanisms triggered by the reconfiguration of the urban renewal programme which continually reduced the subsidies for the housing stock and finally shifted the subsidies from housing towards public infrastructure. Both sections analyse the contingently defined production mechanisms under the new regulatory conditions for social housing and urban renewal, explaining how they affected consumption relations and reinforced processes of uneven development.

\subsection{Abandonment of Subsidies for Social Housing}

For the same reasons that the state traditionally held state-owned housing (see chapter 6), it financed so-called social housing. In the broadest sense, socially financed housing is "housing whose construction and in consequence rents are subsidised from public funds" (Emms 1990: 1). As with state-led housing, social housing is either target to the masses or residualised. Harloe (1995: 7, emphasis in original) argued that states solely support a mass model in times when specific "social, economic and political circumstances limit the scope for private provision and when this limitation is of strategic significance for certain aspects of the maintenance and development of the capitalist social and economic system". Harloe (1995) detects in Europe and in the US a general trend towards the states' retreat from a mass model of housing provision, underlining the withdrawal tendencies from the provision of social services identified by the entrepreneurial city debate (see section 2.3.1). This section explores the development of social housing in Berlin and confirms a transformation from a mass towards a residualised form of housing provision. In order to understand the processes of uneven development, the analysis goes beyond a confirmation of the state's withdrawal from mass housing provision and investigates how the contingently defined production mechanisms play out under a particular form of social housing provision generating processes of uneven development.

In Germany, socially financed housing was traditionally constructed for a broad stratum of the population, reflecting a mass model (see also chapter 4). This was especially the case in the city of Berlin (Krätke and Borst 2000: 165). ${ }^{110}$ Because

\footnotetext{
${ }^{110}$ Between 1949 and 1987, around 80 percent of the new housing construction in West Berlin was state-subsidised, 40 percent of which was social housing (Häußermann and Kapphan 2002). See also chapter 4 .
} 
of the specific status of West Berlin as an isolated city and chronicle housing shortages, both land price and construction costs were high. In order to make rent affordable for Berlin's tenants, but also to make long-term investment more attractive in a city where investment was considered too risky, the state granted high amounts of subsidies. The state subsidised private- and state-owned housing companies through direct grants, the allocation of public construction loans, or an allowance to decrease expenditures for capital and management costs (Hanauske 1995: 39 et seq.). These subsidies decreased the economic rent (Kostenmiete), which was calculated by the costs of credit interest rate, equity yield rate, management costs, and amortisation. ${ }^{111}$ During the time that the housing unit was subsidised, it had to be rented under certain conditions; meaning that rent ceilings were determined at the subsidised economic rent and allocation was restricted to households who received housing vouchers (Wohnberechtigungsschein, WBS) because their income was under a certain level. However, the later the subsidies were granted, the more expensive the credit costs. This means that the social housing stock became increasingly more expensive.

Socially financed housing in Germany was, from the very beginning, designed to become part of the free market after a certain period. The social housing subsidies lasted for 15 years, usually followed by subsidies for another 15 years. Since the subsidies were declining, the state paid less each year and the subsidised economic rent to be paid by the tenant increased. After the 30 years, the so-called subsidy lock-in period ended and housing units became part of the free market. The idea behind this declining form of social housing subsidies was the assumption that tenants' income would increase enough during the 30 -year period so that they would be able to pay the full economic rent. This, however, is based on the assumption of a high degree of stability within the tenants' structure and of their continuously improving financial status.

In contrast to other western European countries (Harloe 1995: 337 et seq.), this form of socially financed housing provision was always considered as an emergency intervention due to the desperate housing shortage after the Second World War (Novy 1991: 20). The decline in social housing transforming from a mass model towards a residualised model of housing provision was pre-programmed (Harloe 1995: 495; see also chapter 4). While most regional governments

\footnotetext{
${ }^{111}$ The economic rent model was criticised as an incentive to overprice the initial investment. Since the interest rate for invested equity and credit capital differed, the initial investment significantly influenced the economic rent level. Furthermore, the critiques of the economic rent model complained about the independence of the economic rent level from the actual market situation. See Kofner (2004) for more details on the economic rent model.
} 
(Länder) in Germany continue to finance social housing, ${ }^{112}$ even though to a considerably lesser degree, Berlin decided to completely withdraw from financing social housing. Analytically, this withdrawal further confirms Berlin's move towards a more entrepreneurial mode of housing provision. What are however the particularities of the abandonment of socially financed housing in the context of Berlin? And how do these particularities play out in practice reinforcing uneven production and consumption mechanisms? It is to this end that this section of the chapter now turns.

In 1998, the government of Berlin ended subsidisation programmes for the construction of social housing. More dramatically however, at the beginning of 2003, the government of Berlin decided to stop the follow-up support of all housing units that fell out of the basic subsidy period of 15 years. All housing that was built with state subsidies between 1987 and 1997 no longer received follow-up subsidies of another 15 years. ${ }^{113}$ This new regulation affected approximately 28,000 housing units (Senatsverwaltung für Stadtentwicklung), which was 15 percent of the social housing stock in 2009. With the premature abandonment of the follow-up subsidies, the government also lifted the rent limits conditions and allocation rules for the affected housing units (Senatsverwaltung für Stadtentwicklung), ultimately integrating these housing units into the free market after 15 years and not 30 years. The government argued that the subsidisation of social housing was no longer feasible because of the high state debt loads (Senatsverwaltung für Stadtentwicklung 2011). A representative of the Senate Department for Urban Development confirmed, and proposed another argument:

"There were two components. On the one side, it was said that there is a depressed housing market and therefore subsidisation is not necessary. On the other side - and from my point of view this was more important - was the financial situation in Berlin. The subsidisation system in Berlin was relatively expensive and therefore a big burden on Berlin's budget." (Employee of the Senate Department for Urban Development, ID5)

The argument, that high vacancy rates were an indication that the free market would provide enough affordable housing, stems from a naïve view of the workings of free housing market, as the following analysis shows.

\footnotetext{
${ }^{112}$ Since 2006, the financing of social housing is the sole responsibility of the regional governmants (see also chapter 4).

${ }^{113}$ The government provided the follow-up subsidies starting in 1972. However, the follow-up support of an extra 15 years had never been contractually guaranteed. Thus, legally, the government had the right to withdraw from its commitment. The Federal Administrative Court confirmed this in a decision from $6^{\text {th }}$ May 2006, after it dismissed an application for further subsidies.
} 


\subsubsection{Production Mechanisms for Former Social Housing}

In Berlin, the abandonment of the follow-up social housing subsidies affected all housing providers that owned social housing built between 1987 and 1997 because earlier built social housing had already been integrated into the free market or received subsidies for the full 30 years. These providers, however, only received 15 years worth of subsidies due to the new regulations even though they based their cost-benefit analysis for the construction of the social housing units on the expectation of receiving state subsidies for 30 years. With the abandonment of the previously committed follow-up subsidies, these housing providers were left with a gap of 15 years governmental financial support. The housing providers consequently had to deal with increasing financial shortage and had to find new financial channels to cover the deficit.

The abandonment of social housing subsidies constitutes a shift in the finance structure of housing, from public to private loans, and from subsidised interest rates to market interest rates defined by the capital market (Priemus and Dieleman 1999). This suggests that the housing providers operated along previously established finance strategies. The abandonment of the follow-up subsidies for social housing coupled with early re-integration into the free market is therefore expected to reinforce the uneven production mechanisms established in the previous chapters 5 and 6 . In order to analyse how the abandonment of the follow-up subsidies reinforced processes of uneven development, this section investigates the following question: How do the different types of housing providers finance, invest, manage, and exchange the former social housing stock that no longer benefits from supply-side subsidies?

The analysis distinguishes between four types of housing providers. First, the previously established value added investment funds, which have a long-term strategy based on creating added value; second, the opportunistic investment funds, which follow a short-term strategy based on leveraging (see chapter 5); and third, the remaining state-owned housing companies, which have to balance economic and social goals (see chapter 6). In addition to the already established housing providers, this section introduces a fourth type of provider: Social housing companies that have exclusively built in the social housing market seg- 
ment. ${ }^{114}$ In contrast to state-owned housing companies (see chapter 5), social housing companies continue to operate in a non-profit manner. The following sections explore how the production mechanisms contingently emerge through these different types of housing companies under the new regulatory conditions for social housing.

\section{Finding new forms of finance for former social housing}

All four analytically distinguished types of housing providers had a certain amount of housing units that were affected by the abandonment of the follow-up subsidies and the early re-integration of the social housing into the free market. The new regulation affected the housing provider depending on how much social housing it owned that was built between 1987 and 1997. This was especially problematic for companies that solely built social housing. Housing providers that had a broader portfolio such as large housing companies owned by value added investment funds or the state were less affected by the new regulations. The division manager of a social housing company explained the impact that the abandonment of the follow-up subsidies had on them:

"With the Senate decision abandoning the follow-up subsidies, the housing companies that built with those subsidies got their legs cut. That means the government cut subsidies that were agreed upon and they are now lacking in the budgets of these housing companies. That affects us strongly because we have only built in the domain of social housing. Thus, we don't see this as a positive decision. What should we do now? How should we deal with this?" (Division manager of a social housing company, ID 25)

Every year, further social housing units built between 1987 and 1997 phased out of the first 15 years lock-in period and therefore no longer received subsidies. For these units, the companies lacked the financial resources that they expected to receive through the follow-up subsidies. This effect is cumulative until 2012 when the last batch of social housing constructed in 1997 phases out of the 15 years lock-in period. The technical manager of a state-owned housing company that was not exclusively in the business of social housing saw the situation less dramatic than the previous respondent. However, the technical manager pointed out the cumulative effect over time:

\footnotetext{
${ }^{114}$ A social housing company owned by a regional church was analysed here. While the company also owns housing on the free market as a result of the specific way socially financed housing comes onto the free market after a certain period of time, it distinguishes itself from state-owned housing companies because it exclusively built within the social housing market. It has therefore no $19^{\text {th }}$-century block developments in its portfolio, but almost exclusively post-war high-rise developments.
} 
"We did not get from one day to the next into a dire economic situation. We were affected, I think in 2006 for the first time, with 200 apartments. The difference between rent and economic rent for 200 apartments is bearable. However, with each year the number of apartments affected adds up and we will have a peak of affected apartments in 2011/2012 when the financial impact is pretty dramatic." (Technical project manager of a state-owned housing company, ID 20)

In a stressed housing market, housing companies possibly fill the subsidies income gap by increasing rent levels (Turner and Whitehead 2002: 207 et seq.). In Berlin, the abandonment of follow-up subsidies was coupled with a release from rent ceilings and allocation rules. As such, housing companies could - at least in theory - increase the rents to the full economic rent level. In practice, however, this was not possible because the full economic rent level is around 15 Euros per square metre (Holm 2005) because of the high construction costs explained above. Housing companies are not able to achieve such high rent levels in Berlin's market environment where the average rent is 4.83 Euros per square metre (Investitionsbank Berlin 2010). Evidence from the past few years confirmed this (Senatsverwaltung für Stadtentwicklung 2011). Housing companies could not achieve cost-effective rent levels for the housing stock that was affected by the abandonment of follow-up subsidies: Despite the release from rent limits, the market situation of the former social housing stock made it impossible to increase rents above the rent levels in the surrounding area. A respondent explained:

"To achieve cost-effectiveness of these housing units is basically impossible because the financing was calculated differently and because the tenant that originally moved in, as a socially disadvantaged tenant with a housing voucher, cannot pay the economic rent which is around 12 to 15 Euros per square metre." (Division manager of a social housing company, ID 25)

Social housing that was released from the lock-in period was often in need of renovation because housing companies had not invested in it during the lock-in period; they had no incentive to do so. The dire housing conditions contributed to the fact that housing companies could not increase rent levels. Because of the abandonment of the follow-up subsidies, the companies lacked the financial means to invest in the improvement of the housing stock. These improvements were however necessary to justify increasing rents. A spokesperson for an association of housing companies in Berlin and Brandenburg stated that the companies lacked funding for renovations and investment in the housing stock as a result of the abandonment of the subsidies:

"The problem is not only that the subsidies are no longer continued, but also that the housing stock affected is getting older 
and investments should be made. However, because the companies cannot achieve effective rent levels and the operating costs are increasing, they lack the money for investment." (Spokesman for an umbrella organisation for housing companies, ID 9)

Companies faced difficulties increasing rents among social housing tenants because they were already low in the surrounding area. This was also because the housing was often in areas with a 'poor reputation' caused by the existence of social housing in these areas in the first place. Investors therefore considered the housing as having low development potential.

As a result of the abandonment of social housing subsidies and the impossibility of raising rent levels, housing providers had to find other ways to deal with the financial deficit. Such a shift from a public structure of finance to a private one usually means replacing "considerations of fairness and bureaucracy" with a "criteria of efficiency and effectivity" (Priemus and Dieleman 1999: 630). This transformation involves market-oriented strategies such as cross-subsidisation (Lawson 2006), selling the housing stock, or reducing maintenance costs (Turner and Whitehead 2002). The concrete investment, management, and exchange strategies however depend on the type of housing company. The following sections explore all the identified strategies that the different types of housing providers applied in order to deal with the financial shortcomings as a result of the abandonment of social housing subsidies.

\section{Selling off or neglecting former social housing}

The lack of finance for former social housing units reinforced the contingently emerging production mechanisms of value added investment funds, opportunistic investment funds, and state-owned housing companies established in the previous chapters 5 and 6 . The former social housing stock that lacked the expected benefit of subsidies has low development potential due to the mechanisms analysed above. Housing providers therefore treated this housing stock according to their investment strategies.

Value added investment funds that followed a cherry-picking strategy avoided the purchase of problematic social housing estates. However, in the cases where they purchased whole housing companies, they could not avoid getting social housing in their portfolio and were therefore unintentionally affected by the abandonment of the follow-up subsidies for social housing (see section 5.4.2). When they could not rent the housing units for a profitable margin, the value added investment funds sold off the unprofitable former social housing stock. A 
respondent of a private housing company that is owned by an institutional investment fund expresses it pretty clearly:

"Housing units with no development potential in poor locations are sold." (Chief financial officer of a private housing company, ID 12)

In contrast to value added investment funds, opportunistic investment funds did not take into account the housing conditions or the regulatory bindings of the housing they purchased. Due to their short-term strategy to sell the housing within a short time period at a higher price than they purchased it (see section 0 ), their investment decision was independent of whether it was social housing or not. During the short time they held onto the housing, they neglected any kind of necessary investments.

As a result of their diverging finance and investment strategies, value added and opportunistic investment funds responded quite differently to the lack of followup subsidies in the particular market situation. While value added investment funds focused on higher market segments and tried to get rid of the former social housing stock, opportunistic investment funds bought it, but neglected it, causing physical and social deterioration of the housing stock (see section 0 ). This starkly contrasted with the government's anticipation that the free market would invest in and provide affordable housing. Moreover, it fostered a deterioration of the quality of the housing.

In comparison to the investment funds, state-owned housing companies and social housing companies had a mandate to provide housing for low income tenants and could therefore not completely neglect the former social housing stock. With the state's consent, state-owned housing companies also sold unprofitable housing stock to reduce their debt, especially when they lacked the financial resources to make the necessary improvements (see chapter 6). Responsible for the mandate to continue providing housing for low income tenants, state-owned housing companies however, could not sell all the former social housing stock. Specifically when the state no longer promoted en bloc privatisation (see chapter 5), state-owned housing companies were left with unprofitable former social housing. They therefore had to keep this type of housing and could not entirely neglect it. This was also the case for social housing companies which were solely active in the social housing market. State-owned housing companies and social housing companies therefore had to find alternative ways to deal with lacking subsidies. 
In general, housing owners with a large portfolio are able to pool rents across different housing units to balance unprofitable housing units with cost-effective ones (Lawson 2006: 70). This strategy was followed by social and state-owned housing companies which cross-subsidised their unprofitable housing units with rent levels from more profitable ones in other locations in Berlin. Both types of housing companies owned considerable amounts of former social housing that was already on the free market. These housing units had benefitted from the 30year subsidies and were not affected by the subsidy default. If these units were located within well-situated neighbourhoods, housing companies could attract a clientele with a higher socio-economic status. With the higher profit margin they offset the lacking subsidies for the housing units they had built between 1987 and 1997. The division manager of a social housing company explained this strategy to balance out the income gap:

"We decided in our company to increase the rents of these [affected] housing units to the average of the rent mirror ${ }^{115}$, sometimes to the upper limit of the rent mirror, but this also depended on the area and the fittings of the apartment. Of course, you can't forget that the fitting is social housing standard that is already 15 years old. We then cross-subsidise the difference between this rent and the economic rent with rents that we get from older social housing stock that already phased out of the lock-in period." (Division manager of a social housing company, ID 25)

Due to the abandonment of the follow-up subsidies, social housing companies were forced to make profits on certain properties, in order to offset the deficit in the social housing stock: They could no longer manage all of their housing at a non-profitable rate. For state-owned housing companies, the pressure was even higher due to the state's profit expectations (see chapter 6). The rent pooling strategy therefore generated an accelerated upgrading of attractive housing in Berlin, because housing companies increased rents of the housing on the free market that had been located in better neighbourhoods or had been equipped with better standards.

The analysis of the different strategies followed by private investors and stateowned housing companies once again shows that it is not concepts of private or public which define the way housing companies operate. Instead, it is the housing providers' finance strategies, their imperative to make profit or provide for low income tenants - or both. State-owned housing companies might therefore

\footnotetext{
${ }^{115}$ The rent mirror is a comparative rent-index. See section 7.2.1 for further explanations of how the rent mirror works.
} 
act in a way only expected of private investors or vice-versa. This underlines the argument that the dualistic conceptualisation of private versus public-led housing provision simplifies complex processes. Rather, a conceptualisation along causal mechanisms such as production relations and the constraints within which actors operate is more useful to understand these processes.

The analysis also shows that the particular state regulation reinforced uneven investment by the different housing providers. The abandonment of housing subsidies for social housing underpinned the constraints faced by housing providers; not only did the social housing stock that came prematurely onto the free housing market not have enough development potential for investment. The housing providers that were affected also lacked the necessary financial resources and became even more constrained to undertake the necessary investments. Value added and opportunistic investment funds divested or neglected this housing because it did not have the necessary development potential to achieve target returns, but they achieved their targets through speculative buying and selling. State-owned housing companies also sold part of this housing stock but together with social housing companies, they were predominantly dependent on crosssubsidising strategies through rent pooling. None of the housing providers however invested into this type of housing.

Contrary to the understanding that the state's withdrawal fosters private investment, its retreat did not trigger a modernisation process of this type of housing. Moreover, the abandonment of social housing subsidies reinforced the deterioration of the former social housing stock. This also affected the provision of the remaining social housing which was continuously reduced and, at the same time, became more expensive. The following section turns towards an analysis of the effects on the provision of housing for low income households.

\subsubsection{Provision of Remaining Social Housing}

With the abandonment of social housing subsidies, private and state-owned housing companies completely stopped the construction of new social housing. ${ }^{116}$ Since housing companies no longer had any financial incentives to build social housing and Berlin's government has not replaced the abandonment of supply-

\footnotetext{
${ }^{116}$ In 2009, social housing made up 18.3 percent of the rental housing stock (Investitionsbank Berlin 2010: 31). Due to historical developments, the social housing stock was almost exclusively in West Berlin. There were additional housing units that were built during the GDR era in East Berlin and, after reunification, were placed under allocation control based on the allocation control law (Belegungsbindungs-gesetz, BelBindG) (Investitionsbank Berlin 2010). See also section 7.1.4.
} 
side subsidies with other regulatory tools, such as planning regulations (Whitehead 2007), there is a decline in affordable housing. Two historically contingent processes are fostering this decline.

First, as described above, social housing was historically established as a temporary condition. The old social housing units were therefore continuously phasing out of the lock-in period and were integrated into the free market. At the same time, housing companies no longer constructed new social housing due to the lack of subsidies. Hence, the amount of social housing declined each year. ${ }^{117}$ Second, credit and therefore housing construction costs increased with time. The rent ceilings that the government determined were therefore higher for later built social housing. As a consequence, the social housing units that did not yet phase out of the lock-in period - and were therefore reserved for low income households - were the ones with higher rent levels. At the same time, the former social housing stock that was already released from the rent and allocation restrictions were the ones that had lower rent ceilings. When housing companies did not invest in the social housing stock that came onto the free market, rent levels in these units remained low.

These mechanisms ensured that the average rent level of social housing was higher than the average rent level on the free housing market. Moreover, between 1999 and 2008, social housing rents increased faster than the rents on the free market. ${ }^{118}$ Figure 7.1 reflects the base rent ${ }^{119}$ development within the social housing stock and shows the accelerating increase of rent levels due to the processes described above. According to the government's housing market report, the average rent for social housing was 5.12 Euros per square metre compared to the 4.83 Euros per square metre for housing on the free market (Investitionsbank Berlin 2010: 44 et seq.).

\footnotetext{
${ }^{117}$ Between 1999 and 2008, the social housing stock under rent and allocation control has decreased by 32 percent to around 9.8 percent of the total housing stock. The Investitionsbank Berlin (2009: 32) forecasts that from the 290,000 social housing units in 1998, only 140,000 will be left in 2018 , because more and more fall out of the subsidised period.

${ }^{118}$ The rent level of the social housing stock has increased with an average yearly growth rate of 3.2 percent between 1999 and 2008. This increase is higher than for the rent levels on the free market (average growth of 2.1 percent per year in the same time period).

${ }^{119}$ Base rent is defined as the rent without operational costs like heating.
} 
Figure 7.1: Base Rent Development of Social Housing (Euro/m² per Month)

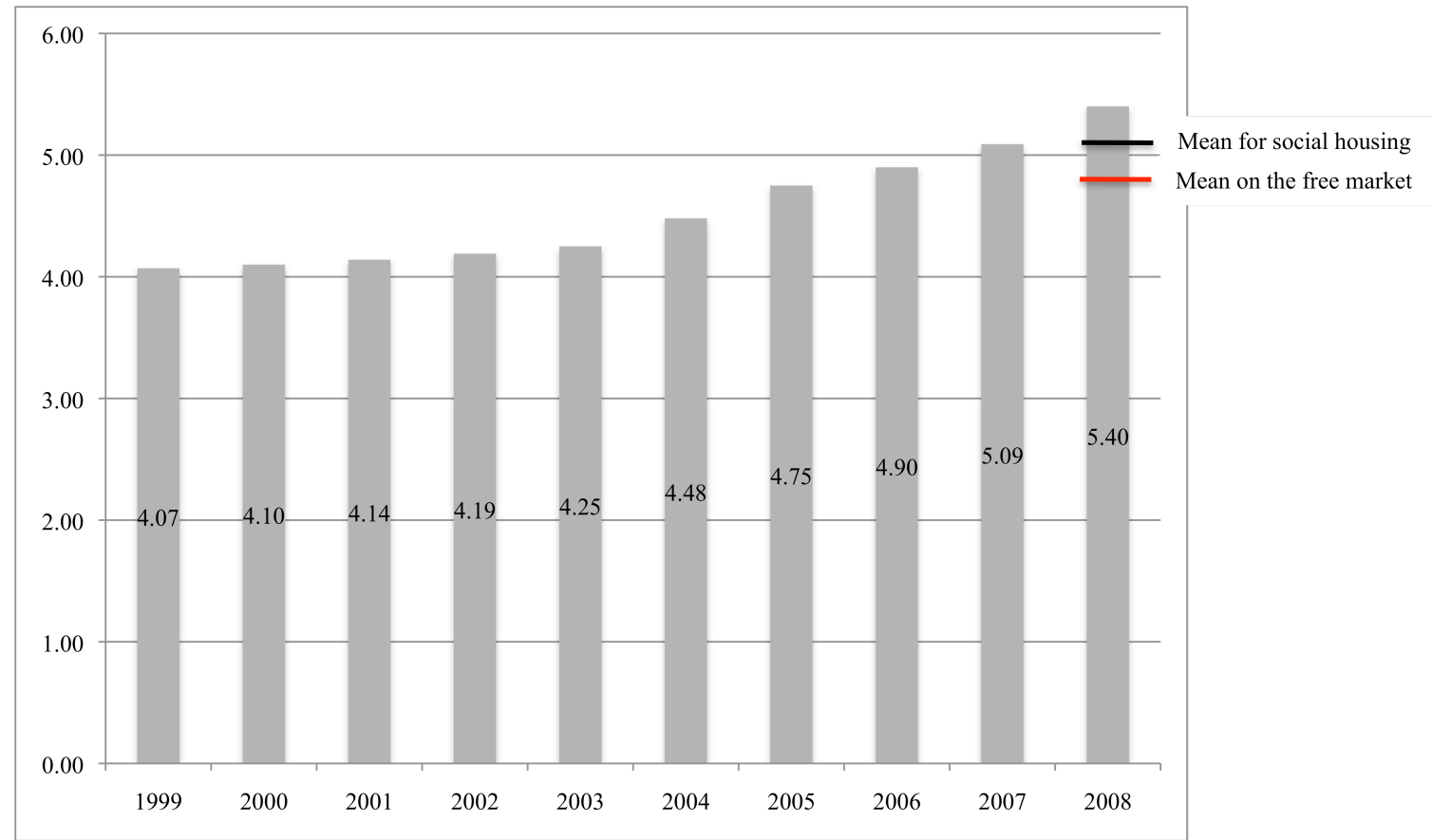

Source: adapted from IBB Wohnungsmarktbericht 2009 (Investitionsbank Berlin 2010: 47).

While the range of rent levels on the free market was much wider, the apartments on the free market that either needed urgent renovation or had lower quality fittings than social housing, pulled the average free market rent down. A representative of the Senate Department of Urban Development confirmed the problem, pointing out that socially financed housing might not be able to play a role in providing for low income households in future:

"In about ten years, there will be around 130,000 social housing apartments left. This is a large reduction and because of the historical development of social housing in large housing estates in certain areas of the city, the effect is a concentration of the remaining social housing. And the second problem is that the housing units that are released from the lock-in period sooner, are the housing units with relatively low rents because they were subsidised through cheap construction credits. This means that the housing that is coming onto the free-market is the cheaper housing. And the remaining social housing has already a relatively high rent. This is from my point of view a problem and there is the question how the remaining social housing can contribute to the provision of housing for poor households." (Employee of the Senate Department for Urban Development, ID 5) 
Figure 7.1 also shows that the real average of rent in social housing is lower than the base rent. ${ }^{120}$ This indicates that housing companies were not able to raise rent levels in the social housing stock according to the government-determined rent ceilings for social housing. This happened because Berlin's tenants could find housing units on the free market that were cheaper than the social housing units.

With no new social housing construction and no alternative regulations, the provision of affordable housing is therefore not secured for the future. According to the 2009 Housing Market Report, only seven percent of the social housing stock was still available for less than four Euros per square metre and will gradually be omitted from the social housing stock by 2015 (Investitionsbank Berlin 2010: 47). This means that there will be an increasing lack of affordable and good standard housing for the poorer population of Berlin. Increasingly, tenants most in need of state assistance cannot access social housing dwellings because rent levels in the remaining social housing units are becoming higher. These tenants have to find housing units on the free market. The free market units at affordable rent levels are however often of substandard quality because housing companies disinvest in these units due to their finance and investment strategies (see chapter 5 and 6).

The increasing lack of affordable housing due to the abandonment of socially financed housing was not especially surprising since it has been documented in other countries (see, for example, Turner and Whitehead 2002). The lack of affordable housing was, however, not due to increasing rent levels as one might expect, but due to particular market relations. As demonstrated, if housing providers did not make the necessary investments, they were not able to increase rent levels. The quality of the housing however deteriorated. At the same time, the remaining social housing (that still received subsidies) became more expensive, which caused a decrease in the affordable housing stock.

The analysis shows that the abandonment of social housing subsidies reinforced the uneven production mechanisms of the different types of housing providers. Under the particular regulatory and market relations, these production mechanisms increasingly created a lack of affordable housing. The following section analyses the changing relations in the consumption of social housing.

\footnotetext{
${ }^{120}$ The average rent ceiling for social housing units is 5.40 Euros per square metre. The real average however is 5.12 Euros (Investitionsbank Berlin 2010: 48).
} 


\subsubsection{Consumption of Social Housing}

As already mentioned, Berlin's social housing stock was historically built for a wide stratum of the population. In the post-war era, new social housing in the outskirts was often considered a better alternative to the rundown inner city housing stock that sometimes still retained signs of war. The middle classes therefore moved into the social housing of post-war high-rise developments (see chapter 4). The following section explores the changes in consumption under the new regulatory conditions and the production mechanisms analysed above. It addresses the following question: How does the demand of different types of income groups and types of household structures shape the process of uneven development under the new regulatory conditions for social housing?

Two processes have been observed. First, better off tenants left social housing units due to particular regulatory conditions, which meant that they would have had to pay higher rent levels in the social housing stock. Second, due to the physical characteristics of certain social housing estates from the post-war era and a particular national regulation that affects households on social welfare, a concentration of large households on social welfare is built up in these estates. The following analysis underlines the argument that the particular production and regulation mechanisms shape the consumption of social housing (Ball 1986; Lawson 2006).

\section{Better off tenants leave social housing units}

Regulatory changes and a lack of investment in the social housing stock created a process where mobile better off tenants left social housing apartments. At the beginning of the 1980s, Berlin's government introduced a fee for households whose income considerably increased over the years. In order to be able to stay in the social housing unit, these households had to pay the fee in addition to the subsidised rent. ${ }^{121}$ This further reflects the change from a social housing model that provides for the masses to a more residualised model (see section 7.1; Harloe 1995). Through the introduction of the fee, better off and mobile tenants had therefore no longer an economic incentive to stay in the social housing unit. The ageing social housing stock coupled with a lack of investment (see section 7.1.1) contributed to the exodus of tenants because the latter were no longer satisfied

\footnotetext{
${ }^{121}$ In 1981, a national law permitted the states to introduce such a fee in order to reduce the number of 'wrongly' subsidised housing (Gesetz über den Abbau der Fehlsubventionierung im Wohnungswesen).
} 
with the value for money (Geyer 1999: 93 in Häußermann and Kapphan 2002: 161). The depressed housing market after reunification (see chapter 1) accelerated this process because housing units with similar standards could be found cheaper on the free market. Tenants who had been living in these estates for a long time, often elderly people who moved in when they were newly built, remained because they were less mobile. At the same time, low income households and immigrants started to occupy the vacant units. These groups had not access to other markets segments because of high rent barriers or active allocation discrimination (see chapter 5 and 6).

These specific processes generated an increasing concentration of low income households in the social housing stock of the post-war high-rise developments (Häußermann and Kapphan 2002: 154). A neighbourhood manager of a large social housing estate described the process and the conflicts that emerged:

"We have here a situation where we have a population that moved into these housing units in the 1960s. When they moved here, these apartments were very modern and the people are still proud that they received these modern apartments. They have brought up their children here and they feel at home here. The children however moved out and these early tenants are ageing. Now, they are confronted with the moving in of the socially disadvantaged, among them a lot of immigrants. The early tenants cannot relate to these families because they have brought up their own children differently. We have conflicts here between old and young, between Germans and non-Germans." (Project director of neighbourhood management team, ID 26)

The increasing social problems that came with a concentration of low income households, especially in the big social housing estates in the periphery, reinforced the processes where mobile households moved out. In areas where this movement took place, the state interfered. In 2002, the government of Berlin abandoned the fee that wealthier households had to pay when staying in social housing units. The aim of this re-regulation was to "create a social mix that is urgently necessary in social housing estates" and to "secure social housing for a broad stratum of the population" (Senatsverwaltung für Stadtentwicklung 2002, author's translation). The state thus tried to incentivise better off tenants to remain in the social housing stock or attract new middle class families in specific neighbourhoods. A few years later, in 2005, the state also abandoned the allocation rules for approximately 40,000 social housing units in order to open up these dwellings for everyone (Senatsverwaltung für Stadtentwicklung 2005a). 
The simple lifting of the fees and the allocation regulation had however no impact on the social structure of the social housing estates. The representative of the Senate Department for Urban Development confirmed this:

"The record shows that even in the areas where the allocation rule has been lifted, it is mostly the population strata which is entitled to a housing voucher that moves into the social housing stock." (Employee of the Senate Department for Urban Development, ID 5)

This was primarily the case for social housing that was not modernised. And housing companies did not upgrade social housing units because as long as the housing stock was locked-in, there was no incentive to so; and when the social housing stock came onto the free market, it was mostly not cost-effective to do so (see sections 7.1.1). The lack of investment in the less-well located social housing stock hollowed out the government's efforts to attract wealthy households to some of the disadvantaged neighbourhoods. The analysis shows that the state's changes to regulate previous rounds of uneven development (the exodus of better off tenants) did not play out the way it anticipated or hoped for. The uneven production mechanisms, which predominantly neglected the social housing stock, shaped the consumption.

\section{Large households on social welfare move into certain social housing estates}

Income mechanisms did not only shape the process of uneven development under the specific regulatory conditions and production mechanisms. Specific types of households also shaped processes of uneven development. In social housing estates from the 1960s and 1970s, a concentration of large households could be observed. Again, production mechanisms and regulatory processes caused the unevenness of housing consumption.

Social housing estates from the 1960s and 1970s were standardised and constructed with generously sized rooms. ${ }^{122}$ This had the effect that even though the rent per square metre was still relatively low, the apartment was becoming unaffordable because of the unit's size. Smaller households had to leave the premises because they could not afford the increasing rents. The neighbourhood manager regretted the exodus of smaller households:

\footnotetext{
${ }^{122}$ A social housing estate from the 1970s that was analysed contained two-room apartments of 80 square metres. The living room or lounge is counted as a room, thus a two-room apartment in Germany is the equivalent of a one-bedroom plus lounge apartment in the United Kingdom.
} 
"The last senior citizen households have also moved out of this estate because they could no longer afford the rents." (Project director of a neighbourhood management team, ID 29)

This affected people on social welfare even more because of regulatory changes to their housing allocation. With the reform of the social welfare regulations on the national level, households on social welfare were allocated housing by the job centre according to an 'adequate rent' for the number of people living in the same household. ${ }^{123}$ The adequate rent was based on a certain number of square metres per person. In the end, social housing estates with large sized bedrooms became too expensive for smaller households on welfare and they had to relocate. $^{124}$

The job centre then allocated the generously sized apartments to larger households that matched adequate rent criteria. Because the apartments of the estate were standardised, the job centre automatically created an unintended concentration of larger families on social welfare. These families were often immigrants. The social structure of these housing estates then prevented better off households who were not on social welfare from moving in. Again, the abandonment of the allocation (see above) could not change this process. The neighbourhood manager of such a social housing estate complained about this process:

"The problem is, these apartments are very generous in their size. That means the households that are moving into these apartments nowadays are not a family with two children because in this case the job centre would not pay the rent. And private tenants who earn their own money would of course never voluntarily chose to live in these housing units where each balcony has a satellite dish, where the children go to a school with seventy percent immigrants, where German is no longer spoken." (Project director of the Neighbourhood Management Programme, ID 29)

The bigger families were allocated these generously sized apartments while smaller households could no longer afford them because they were not allocated and did not receive a subsidy. In this case, the national regulatory conditions for households on social welfare had a major impact in shaping this process. More-

\footnotetext{
${ }^{123}$ According to social welfare regulations (Hartz-IV), adequate housing in Berlin for a oneperson household costs no more than 378 Euros including all utilities and heating costs; for a two-person household it is 444 Euros (Senatsverwaltung für Integration Arbeit und Soziales 2009).

${ }^{124}$ Eekhoff and Mackscheidt (2006), in their study on the consequence of the changing regulation in social welfare at the national level, emphasise that the municipal governments have to pay the housing costs of persons on social welfare. This means that municipalities, especially those with financial difficulties, are increasingly under pressure to strictly apply these living standard adequacy regulations. In these municipalities households on social welfare will most likely be relocated because the government cannot sustain subsidies for these tenants' housing.
} 
over, the specific physical characteristics of the monotonous, but generously sized post-war social housing estates played an important role in the concentration of large households on social welfare. The local state's attempt to create a more diversified social structure in such social housing estates did not have an impact under these conditions.

The concentration of low income households has been confirmed for other countries where governments re-regulated the social housing provision (Van Kempen and Priemus 2002; Whitehead and Scanlon 2007: 6). This analysis shows the particular production and regulatory mechanisms that shaped this concentration in Berlin. It also shows that there is not only a concentration of low income households, but under specific circumstances, there is also a concentration of specific types of low income households, such as large families.

\subsubsection{Synthesis of Key Mechanisms in Social Housing and Their Spatial Outcomes}

The abandonment of subsidies for social housing can be regarded as a shift towards a more entrepreneurial, market-oriented mode of regulation with regards to housing provision. The analysis however shows that a reductionist view of the abandonment of government institutions and the infiltration of market mechanisms often put forward by the entrepreneurial city debate (see, for example, Swyngedouw 2000; Meyer 1995) is not sufficient for understanding the complex processes of uneven mechanisms. It is not enough to confirm the transformation of the state towards a more entrepreneurial form. In order to understand the processes of uneven development, there is a need to investigate the uneven production and consumption mechanisms, triggered intentionally or unintentionally by particular state regulation.

With the abandonment of social housing subsidies, the state halted the construction of new social housing. At the same time, the state's abandonment of followup subsidies for social housing created financial havoc for housing companies owning social housing that was built between 1987 and 1997. This triggered mechanisms that were not necessarily anticipated by the government. In the particular market situation, housing companies were not able to adjust rent levels cost-effectively and therefore had to find other ways to balance their income gap. This, in consequence, reinforced the uneven production mechanisms of the different housing providers. Value added funds divested or neglected the unprofitable former social housing. State-owned housing companies did the same until the government stopped promoting en bloc privatisation. Opportunistic investment funds did buy these housing estates, but did not invest and upgrade them. 
Thus, the withdrawal of the state did not foster investment for the modernisation of former social housing ensuring their eventual neglect. State-owned housing companies and social housing companies, both of them with a mandate to provide for low income households, did adhere to unprofitable housing and crosssubsidised with rents from more profitable housing stock.

Due to the historical development of social housing, the abandonment of the supply-side subsidies created an increasing gap between cheap, but belowstandard housing on the free market, and more expensive social housing. Again, the government's anticipation that the free market would be able to provide for low income housing could not be confirmed. While opportunistic investment funds did provide housing for low income residents through their 'discount housing' strategy (see section 5.4.3), they did it in a way unintended by the government - by neglecting the housing stock and creating problematic neighbourhoods. The decline in social housing units coupled with increasingly expensive rents in the remaining social housing stock, points to the fact that it got difficult for low income households to find good housing.

The processes of uneven development are caused by the diverging strategies that the different housing providers applied. Likewise, each of the strategies is inherently uneven because of the selective investment. The different investment strategies all create a revalorisation of well-situated housing stock and an increasingly neglect of dwellings that actually need investment, such as former social housing. These uneven production mechanisms also influence the consumption mechanisms. Under the specific regulatory conditions, the disinvestment of housing companies in the non-profitable housing stock creates a concentration of low income households and large families on social welfare in certain housing estates.

Critically, as a result of the spatial development of social housing, these mechanisms had different effects on their respective neighbourhoods. Figure 7.2 illustrates the distribution of social housing and allocation restricted housing in the districts in 2009. Most of the social housing stock was located within the western part of the city. This was because social housing was only built in East Berlin after reunification until the abandonment of the social housing subsidy in 1998. The housing stock built by the government in East Berlin was not considered social housing after reunification, but received the status of allocation-restricted housing. In comparison to social housing, allocation-restricted housing units had no rent ceilings, but only allocation restrictions. 
Figure 7.2: Distribution of Social Housing in the Districts $2009^{125}$

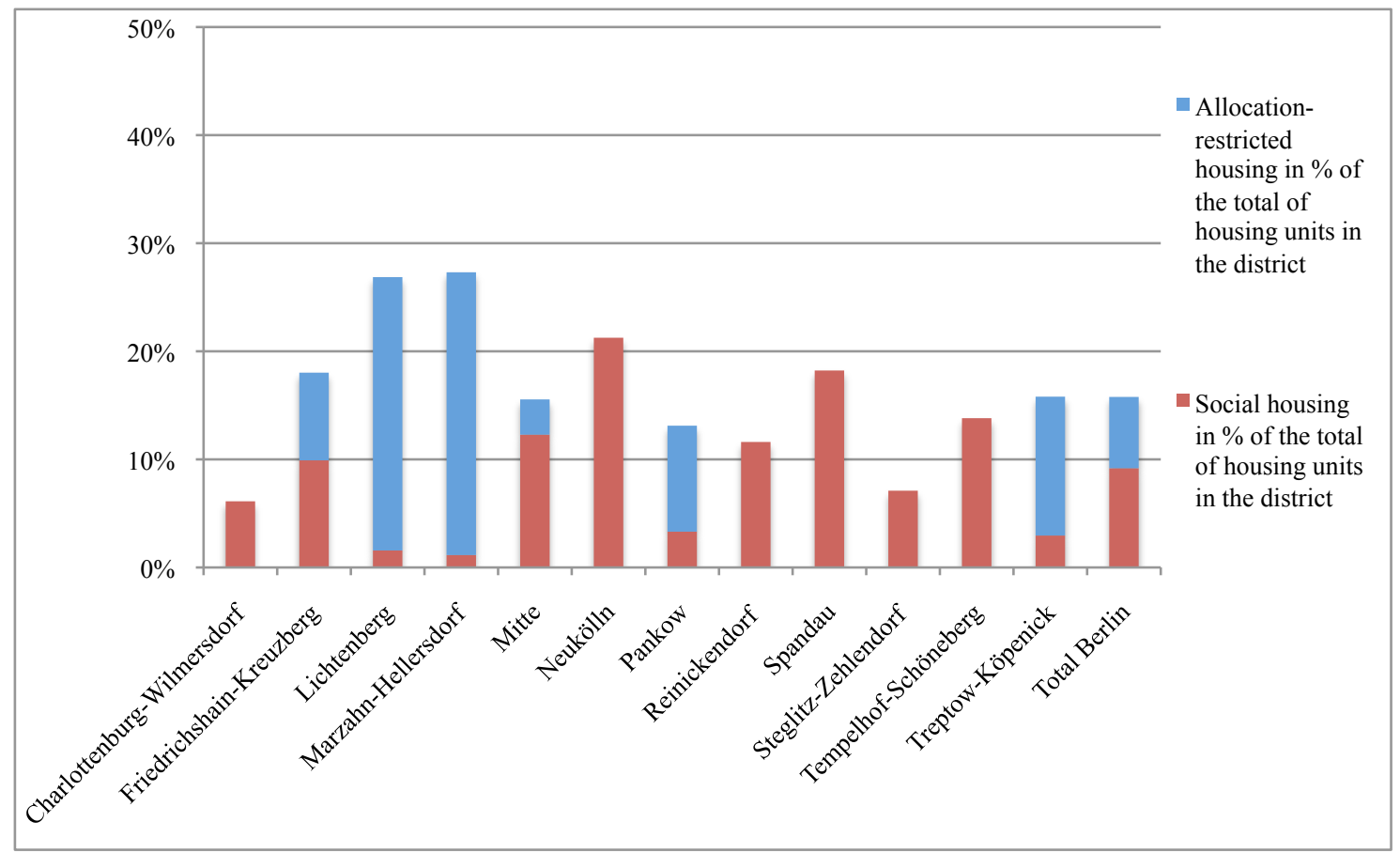

Source: adapted from IBB Wohnungsmarktbericht (Investitionsbank Berlin 2010).

The distribution of the social and allocation-restricted housing had three consequences. First, since the social housing stock in the eastern part of the city was built between 1991 and 1997, this area will no longer have social housing after 2013 because of the abandonment of the 15 year follow-up subsidies (Lichtenberg, Marzahn-Hellersdorf, Pankow, Treptow-Köpenick, and parts of Friedrichshain-Kreuzberg and Mitte ${ }^{126}$ ). Second, the increasing exclusion of social housing from the lock-in period affected the western parts of the city most because western districts had most of the social housing stock (Mitte, Neukölln, Reinickendorf, Spandau, and Tempelhof-Schöneberg). Third, the allocationrestricted housing units in the eastern parts of Berlin will only be available until 2013 according to established law (Senatsverwaltung für Justiz 1995). Thereafter, it will be released from any restrictions. ${ }^{127}$ With this continuous decline of social

\footnotetext{
${ }^{125}$ Unfortunately, it was not possible to find geographical data on the housing stock that is affected by the abandonment of the 15-year follow-up subsidies.

${ }^{126}$ Friedrichshain-Kreuzberg and Mitte are two districts that have been merged with districts from West Berlin (Kreuzberg was part of West Berlin; Mitte integrated the Western districts of Tiergarten and Wedding). These districts therefore have a mixture of social housing that was built before reunification in the West and of social housing that was built after reunification.

${ }^{127}$ For some of these housing units, Berlin's government and the housing companies agreed on a release from the allocation restriction for several years. This is because this housing stock has a relative high degree of vacancies. The government hopes that by releasing this housing stock from the allocation restriction, the government will be able to restrict allocation in the future as needed.
} 
and allocation-restricted housing, there will be an increasing concentration of social housing in certain districts due to its historical distribution.

\section{$* * *$}

\subsection{Reconfiguration of Urban Renewal}

Traditionally, state-led urban renewal was a means to battle housing shortages and improve dwelling conditions in inner city areas that were destroyed in World War Two (Edgar and Taylor 2000: 165). The state initially helped the private market which was not able to make the necessary investments (Smith 2002: 438). In recent years, state-led urban renewal of inner city housing has often been connected with a more entrepreneurial urban strategy. The state uses urban renewal strategies to strengthen the competitive position of the city by attracting investment, but also wealthier people to increase its tax base (Harris 2008). Moreover, governments deal with disadvantaged neighbourhoods by promoting the influx of middle and upper income families, in order to disintegrate the concentration of the poor and improve the social mix of neighbourhoods (Lees 2008), often leading to the displacement of poorer households (Davidson 2008). These urban renewal strategies are connected to a more private-led housing provision, where the state is no longer subsidising the provision of housing, but continuously withdrawing from supply-side subsidies in favour of creating incentives for privateled urban renewal (see also chapter 2). This section investigates how the changes towards a more entrepreneurial strategy of housing renewal played out in Berlin. It not only investigates the particular form in which the state reconfigured its urban renewal strategy, but more importantly how the production mechanisms of previously established housing providers play out in practice under the particular regulatory conditions of urban renewal.

I analytically distinguish three phases of regulatory conditions in Berlin's urban renewal process: First, the direct subsidisation of urban renewal coupled with strict rent ceilings and allocation rules; second, the change towards tax incentives for private investors; and third, the abandonment of any subsidies towards the renewal of housing. The reconfiguration of the urban renewal programme analysed in the three phases shows the changing rules, which brought about a shift towards a more entrepreneurial mode of housing renewal in Berlin. The state has been continuously withdrawing from its commitment to renovate the city's old housing stock and concentrates its actions towards the creation of incentives for private housing developers to do the task. In order to understand the reasons for how these urban renewal regulatory conditions create uneven spatial develop- 
ment in Berlin, the following sections turn to the contingently defined production mechanisms during the three phases of reconfiguration and the changing consumption relations these promoted.

\subsubsection{Production Mechanisms of Urban Renewal Housing}

In order to understand the production mechanisms of urban renewal housing, three types of housing providers are important to consider. While each has played a key role in one of the phases, they co-exist today under equal regulatory conditions. In the first phase of urban renewal that took place before reunification in the neighbourhoods of West Berlin, the state commissioned predominantly state-owned housing companies to renew old $19^{\text {th }}$-century block development housing (see also chapter 4). Already towards the end of the first phase, but primarily in the second and third phase, the state commissioned urban renewal agencies to coordinate the investment of private landlords within the designated urban renewal areas, predominantly in the inner city districts of East Berlin. In the second phase, small-scale private investors played a major role. ${ }^{128}$ In this phase, institutional investors have not yet entered Berlin's housing market on a large scale. The urban renewal programme of the second phase helped however to create demand for $19^{\text {th }}$-century block developments which value added investment funds then used to strategically invest in housing with development potential once they entered Berlin's housing market (see chapter 5). ${ }^{129}$ The third phase marked a complete shift from housing renewal towards the support of infrastructure renewal. The state redirected the funds for the improvement of parks, schools and other public infrastructure, and counted exclusively on private investment for the renewal of housing.

The following section investigates how urban renewal strategies became incorporated in the entrepreneurial strategies of Berlin's government. Going beyond the identification of urban renewal as an entrepreneurial strategy, the section then explores the contingently emerging production mechanisms under the regulatory conditions of the three phases. It investigates the uneven development processes

\footnotetext{
${ }^{128}$ The small-scale investors are analytically difficult to differentiate because of their heterogeneous ownership structure (Holm 2006: 126). Due to the thesis' focus on institutional investors and state-owned housing companies, the analysis of small-scale investors is based on the existing literature's detailed account of urban renewal in the district of Prenzlauer Berg in the former East Berlin (Häußermann et al. 2002; Bernt and Holm 2005; Holm 2006) and interviews conducted with a district councilor of urban development, a head of a department for urban redevelopment projects and two representatives of a tenant consulting service in an inner city district in former East Berlin.

${ }^{129}$ Opportunistic investment funds did not have a particular interest in this type of housing because they were looking for cheap stock in order to re-sell it at a higher price (see chapter 5).
} 
that the different phases triggered and addresses the question: How do the different housing owners invest and manage the urban renewal housing under the specific regulatory phases?

\section{First phase: Subsidies and rent ceilings}

Urban renewal programmes ${ }^{130}$ were initially aiming at the improvement of the derelict housing stock of the late $19^{\text {th }}$-century block developments in West Berlin. The programmes were structured similarly to the social housing construction programmes: The government provided grants for the modernisation of the housing stock and subsidised rents according to a predetermined limit. Districts received allocation rights with priority for tenants that were affected by the urban renewal process. As within the social housing stock, the predefined rent level continuously increased until the subsidies were exhausted or repaid, and the housing was released on the free market. Due to public protests that led to the urban renewal of old housing stock in inner city areas (see chapter 4), the process was characterised by a high degree of public participation. At first, state-owned housing companies executed the modernisation. The government mandated that state-owned housing companies buy the housing from the private owners who were unable or not prepared to modernise the housing units themselves and willing to sell them. Later, the government increasingly also collaborated with private housing investors.

\section{State-owned housing companies modernised under strict rent regulations}

The highly subsidised urban renewal process with public participation and strict rent limits created a slow modernisation process. Under these conditions, the state-owned housing company ${ }^{131}$ that was in charge had to negotiate the process with the state with regards to renovation costs, rent and allocation rules. At the same time, the state-owned housing company had to negotiate with the existing tenants, taking into account their capacity to pay higher rent levels and accordingly adjust the form of modernisation. The project manager of a state-owned housing company described this process:

\footnotetext{
${ }^{130}$ The urban renewal program was first introduced in the late 1960s and aimed at tearing down the old housing stock and building new large estates. This strategy was especially followed in the poorer areas. It had similarities with slum clearances in the Anglo-Saxon countries (Hall 2002: 240 et seq.). With increasing protests against this form of urban renewal, from the late 1970s onwards, the state had adopted a strategy with a more sensitive approach where old housing stock was renovated rather than torn down (see also chapter 4).

${ }^{131}$ During the first phase of urban renewal, state-owned housing companies still acted under the principle of the common public interest (see section 6.1) and therefore were constrained in their profit maximisation.
} 
"We had a contract with the government where every detail was regulated from buying the neglected housing, to the process of modernisation and future rent ceilings. [...] At the beginning, the duty was to modernise the housing keeping rent levels at a moderate level in order to prevent tenants from dislocating. [...] When, for example, a gas system had to be renewed and it could not be paid from the current rent, Berlin [the government] - according to the contract - covered the deficit." (Technical project manager of a state-owned housing company, ID 20)

It was not only the regulatory conditions that influenced the state-owned housing companies' investment in Berlin's urban renewal. Because of the participatory planning process, the modernisation also depended on tenant engagement. In neighbourhoods where tenants were actively participating, state-owned housing companies could only invest with the tenants' consent. This led to less displacement. A collaborator of a tenant consulting service who was involved in the whole process since the beginning expressed her satisfaction:

"It was all terrific - during the urban renewal process and even at the end. I was impressed how we managed the process, how the tenants were satisfied and no one was displaced." (Collaborator of a tenant consulting service, ID 21)

Urban renewal in the first phase was highly subsidised, investment processes were negotiated and displacement of tenants was prevented. The process of state subsidies linked to predetermined rent ceilings contributed to a relatively standardised investment process, independent from the state-owned housing company in charge. The urban renewal process was thus characterised by a social regulatory overview where tenants' interests were represented. This drastically changed with the second phase of urban renewal.

\section{Second phase: Tax incentives and relaxed rent regulations}

The situation dramatically changed after reunification. Before reunification, the government of West Berlin intervened in the urban renewal of its old housing stock because private investors were not willing to stem renovation costs without state support. It was too risky to invest. Urban renewal was considered as a way to battle the housing shortage and improve the physical structure of the sometimes still war-torn housing (Häußermann and Kapphan 2002: 75 et seq.). This created the investment processes described in the first phase.

However, between 1993 and 1995, the government of Berlin reconfigured its urban renewal programme. The aim was now not only to improve the physical condition of the housing, but to "increase the competitive position" of these urban renewal designated districts (Senatsverwaltung für Stadtentwicklung, 
author's translation) and to foster the influx of population groups that have a "stabilising effect" (Senatsverwaltung für Stadtentwicklung 2005c: 1, author's translation). In comparison to the first phase of urban renewal, which was at least partly a bottom-up approach with active tenant participation, the second phase of urban renewal was a top-down approach. The government designated 22 new urban renewal areas, now mostly in East Berlin. ${ }^{132}$ Some of the older urban renewal areas in West Berlin were however still designated as urban renewal areas and were now treated under the same regulatory conditions as the newly designated urban renewal areas.

With less money than for previous rounds of renewal, the state subsidised the renovation of East Berlin's old housing stock by providing tax incentives to private investors in exchange for allocation rights for a portion of the housing stock. A commissioned urban renewal agency in each designated neighbourhood coordinated the investment process. This second phase was the initial step of withdrawal from direct state intervention in the modernisation of old housing stock within inner city areas. With tax incentives instead of direct subsidies, the state hoped to attract private investment and therefore speed-up the modernisation process of the inner city neighbourhoods of former East Berlin (Bremer et al. 2007). At the same time, rent regulations for urban renewal housing were relaxed.

The state, through its re-regulation, fostered the revalorisation of the designated urban renewal areas. This more private-led form of housing renewal could however only happen because the fall of the Wall made investment in Berlin attractive again and investors could capitalise on a particular rent gap. The following sections explore the contingently emerging production mechanisms of - and at the time predominantly - small scale private investors and how they produced this upgrading process under the particular regulatory conditions of the second urban renewal phase.

\section{Private investors capitalised on a rent gap}

With the abandonment of direct state subsidies for urban renewal, housing providers became more dependent on the capital market for housing renewal investment credits. Investors were therefore subject to market conditions. Besides the tax deductions for investment in housing renewal, the possible financial re-

\footnotetext{
${ }^{132}$ See Holm (2006) for an analysis of the effects of urban renewal on a specific neighbourhood Prenzlauer Berg.
} 
turns after renewal, through resale or rental income, became the most important factor for investment decisions (Holm 2006: 157).

In the urban renewal designated areas of former East Berlin, housing providers, at the time especially small-scale private investors, capitalised on the existing rent gap (Smith 1996: 51 et seq.). The housing stock of the inner city areas in East Berlin had been what Smith (1996: 65) calls "under-maintained" for many years. In a capitalist market system, a housing shortage such as the one that occurred in East Berlin before reunification would have stirred housing investment because rent levels could have been increased. However, in the planned economy of East Germany, the housing stock of East Berlin was completely abandoned for ideological reasons and rent remained at pre-war levels. ${ }^{133}$ At the time of reunification, the housing stock was rundown. This led to a rent gap whereas the actual price was considerably lower than the potential profit of the dwellings. According to Holm (2006: 205), this under-maintenance of the housing stock was the key factor triggering the fast-paced modernisation process. Since the state no longer subsidised unprofitable urban renewal costs as it did in the first phase, private investors were under greater pressure to make the investment profitable. However, because they could not increase rents to a profitable level without modernising the housing stock, they renovated the housing - often to a high standard.

The particular tenant structure in these designated urban renewal areas also facilitated the capitalisation of the existing rent gap. The buildings' decline in value is often accompanied by a move-in of socially disadvantaged tenants (Smith 1996: 66). This was however not the case in East Berlin's urban renewal areas. While there were considerable vacancies after reunification, the remaining tenants were part of a highly educated class that stayed in these dwellings for life-style and ideological reasons (see chapter 4). Investors therefore found an existing clientele that was able to pay higher rent levels. A respondent explained this specific condition:

"Here, the buildings were in extremely poor condition, they were all dilapidated [...]. But the social structure of the residents was completely unproblematic. It was actually very good. Normally, as for example in West Berlin, when you have such deteriorated housing, you would also have a problematic tenant structure with a lot of foreigners or the socially disadvantaged. This was not the case here. And this was attractive to the private investor, because

\footnotetext{
${ }^{133}$ See chapter 4 for a discussion of how East Berlin's government neglected the housing stock in the inner city.
} 
it did not have to force the problematic tenants out first, but had a clientele that could afford paying higher prices. [...] This was the reason for the specific dynamic that took place. [...] I think this was very special." (District councillor for urban development, ID 11)

Investment strategies then also affected rent levels in the renovated housing where the state's regulatory conditions were considerably relaxed in the second urban renewal phase.

\section{Private investors modernised under relaxed rent regulations}

In this second phase of urban renewal, the state abandoned rent ceilings, reducing its control over market mechanisms. Before 1995, the subsidies were tied to a predefined rent ceiling that increased a certain amount each year in accordance with the declining subsidies. Therefore, state-owned housing companies only increased rent levels in the designated urban renewal areas according to predetermined ceilings. Because of this regulation, the tenant could foresee the rent increase for as long as the housing units were subsidised. With the deregulation during the second phase of urban renewal, after 1995, the rent ceiling in urban renewal areas was based on the average of the 'rent mirror', a comparative rent index that also regulated rent levels on the free market.

Mechanism of the rent mirror: To understand the difference between the predefined rent ceilings of the first phase and the rents based on the average of the rent mirror, the workings of the rent mirror have to be briefly explained. Together with tenant and landlord organisations, the state evaluates the comparative rent index every four years. ${ }^{134}$ On the free housing market, this rent index applies to existing tenancy agreements (Bundesministerium der Justiz 2009). Within a time period of three years, the rents of existing tenants then cannot be raised above twenty percent of the comparative rent. Tenants who newly move into an apartment and sign a new tenancy agreement are however not protected by the comparative rent regulation. This specifically affects the rent levels of free market $19^{\text {th }}$-century block developments because demand is high enough that value added investment funds increase rent levels to earn more profit through higher income streams (see section 5.4.2). Tenants who seek housing in these develop-

\footnotetext{
${ }^{134}$ Rents are regulated on the national level based on the principle of comparative rent of an area (ortsübliche Vergleichsmiete). In order to define the comparative rent for a specific place, most communities, especially bigger cities, develop a so-called "rent mirror" every four years. Berlin's "rent mirror" is based on a sampling method and negotiations between stakeholders. It is a comparative rent scheme with different rent indices regarding the type, size, configuration, quality, and location of the housing unit.
} 
ments often pay higher rent than the indexed rent. ${ }^{135}$ These newly negotiated rents then influence the next rent mirror reflecting a higher average rent level in the $19^{\text {th }}$-century block developments. With a new rent mirror that appears every four years, rent increases are legitimised for existing tenancy agreements on the free market and in designated urban renewal areas. In urban renewal designated housing, the owner can consequently increase rents to the average rent of the comparative index which is the rent ceiling. In $19^{\text {th }}$-century block development neighbourhoods with high demand, this process is creating a self-reinforcing cycle. The time lag of four years is slowing down, but not halting the revalorisation process.

With this regulatory change from predefined rent ceilings to the rent average of the mirror, both private investors and state-owned housing companies increased rent levels. In contrast to the former social housing stock, demand for the urban renewal housing was high and private investors, as well as state-owned housing companies, could raise it the maximum amount possible. The mechanism of the rent mirror therefore accelerated the increase of rent levels in urban renewal housing of $19^{\text {th }}$-century block developments.

When urban renewal neighbourhoods were released from their designated status and planning permission was no longer needed for renovation, investors were prone to further modernise the housing in order to increase profits. This was also because they could pass renovation costs onto the tenants. ${ }^{136}$ The release from urban renewal designation created a system where investors luxuriously modernised housing for the sake of increasing rents. The responsible person for urban renewal areas in a district pointed this out:

"Especially in this neighbourhood, the fact that we cannot limit rent levels is a problem, because the neighbourhood is in an area that is very popular among tenants, also among those who earn good money. And the former population that not necessarily earns a lot of money, there are also pensioners among them, has to worry about being dislocated. There are also renovations taking place that redo something that has already been modernised. This results again in increasing rents. And the private owners always get the apartment emptied." (Collaborator of a tenant consulting service, ID 21)

\footnotetext{
${ }^{135}$ An analysis of the latest rent mirror shows that rent levels for new tenancy contracts are considerably higher than rent levels in existing tenancy agreements (Müller 2009).

${ }^{136}$ The housing owner can transfer 11 percent of the modernisation costs onto the rent. Even when the costs are amortised, the rent remains at the higher level.
} 
The state's reconfiguration of the urban renewal programme was not a mere withdrawal from the housing provision. Moreover, it was this reconfiguration which allowed value-creating through investment. It thus was not the mere withdrawal of the state that created the revalorisation of housing, but the way in which it incentivised investment without a social regulatory overview representing tenants' interests. The appreciation of housing also benefitted the state itself with regards to its own housing companies' financial situation (see chapter 6). The following quote from a representative of a state-owned housing company shows that the state no longer hindered its housing companies to increase rent levels in urban renewal areas.

"Towards the end of the 1990s, the state forced rent increases. Rents for new tenants after the renewal were also pushed significantly higher with the aim to improve profitability and therefore also Berlin's budget." (Technical project manager of a stateowned housing company, ID 20)

The upgrading of inner city areas through investment and increasing rents created processes of displacement. The government still required a social plan for when urban renewal "expected to negatively impact the personal circumstances of the affected tenants" in order to prevent a displacement of low income households (Senatsverwaltung für Stadtentwicklung 2005c: 1, author's translation). However, while existing tenants were not necessarily directly displaced due to the regulatory conditions in place, urban renewal created a process of exclusionary displacement where low income households are no longer able to move into these neighbourhoods (Marcuse 1986).

This second phase of the changing regulatory conditions marked the first step towards a more entrepreneurial form of renewal. Urban renewal was used as a strategy to promote private investment in the city and its built environment. The particular way in which the state deregulated rent levels and attracted investment through tax-incentives without public participation generated production mechanisms that fostered the capitalisation of the existing rent gap. At the time, it was predominantly small-scale private investors that invested in the urban renewal of the designated areas. Due to their heterogeneous character, it is difficult to differentiate the specific strategy that each investor followed. However, in order to make investment in these urban renewal areas profitable, it was essential to modernise the housing stock to create demand and increase rent levels (Holm 2006: 126). 
In contrast to the first phase of urban renewal, the modernisation process of the reconfigured urban renewal programme generated a much faster renewal process. It was a process that was, so the analysis suggests, anticipated by the government. The fast-paced upgrading process however also brought about increasingly indirect and exclusionary displacement of tenants (see also section 7.2.2). In contrast to modernisation, the government did, at least officially, not anticipate the displacement; it was an unintended consequence. Once a majority of the old housing stock was renewed, the state reconfigured the urban renewal programme once again.

\section{Third phase: From housing to infrastructure}

In 2002, the programme entered what is analytically identified as its third phase. This time, the government withdrew completely from the subsidisation of housing renewal and proclaimed that it ought to be a task for private capital. Urban renewal subsidies were now exclusively targeting the modernisation of infrastructure and the improvement of the urban environment in designated neighbourhoods. The new programme declared that public money would only be allocated for public buildings (Senatsverwaltung für Stadtentwicklung 2005c: 2). This entailed less financial responsibility for Berlin's Senate Department for Urban Development which was no longer able to support housing renewal.

In this third phase of urban renewal, the engagement of private capital was no longer sought with tax incentives (Senatsverwaltung für Stadtentwicklung), but instead with the improvement of infrastructure such as schools and parks. By upgrading public infrastructure, the state attracted private investors to upgrade its housing stock. A district politician questioned the new urban renewal strategy of Berlin's government:

"I can quarrel for a long time about the fact that in 2000, the government of Berlin stopped investing into housing and now invests in public space. At first, this sounds reasonable. But one could also ask why the state should now additionally improve the residential environment with public money further benefiting private investors. However, why should the state not? It makes no sense when the schools are in a poor state. This is a difficult question." (District councillor for urban development, ID 11)

Without tax incentives for housing renewal, providers made their decisions solely based on the calculation of the return on the investment after modernisation. This reinforced the pressure to increase rent levels after modernisation. With the abandonment of state subsidies towards housing, the state could no 
longer influence rent levels beyond general rent regulations. A respondent confirmed this:

"You had the phase before 2000/2001 with the commitment of public subsidies, where the state could negotiate the renewal goals with the private landlord, where it had considerable power to offer something. From 2001 onwards, after there were no more public subsidies, the state could no longer offer anything and therefore it was not entitled to demand anything. From 2001 onwards, this has led to increasing gentrification of this district." (Former project manager for the development of a housing estate employed by an asset management company, ID 13)

State-owned housing companies and private investors, and now increasingly also value added investment funds, operated according to their strategic goals (see chapters 5 and 6) without any specific regulatory obstacles. In market segments that benefitted from a relatively high demand such as the urban renewal areas of the $19^{\text {th }}$-century block developments, the removal of regulatory challenges created a reinforcing investment and revalorisation process. Alternative forms of housing subsidies that were still available played only a subordinate role as the next section shows.

State-owned housing companies and value added investment funds modernised under market conditions, rarely using alternative forms of housing subsidies

With the further reconfiguration of the urban renewal programme, the government of Berlin completely abandoned its commitment to the renovation of the old housing stock. Even though the government still had to pay subsidies to honour former commitments, it abandoned any further engagement in this domain and does - according to a representative of the Senate Department for Urban Development - not plan any new intervention to subsidise housing construction or renovation. As a consequence of this reconfiguration from public to private urban renewal, the state continuously reduced its influence within the domain of housing provision. The following quote summarises the process.

"Housing renovation used to be connected to high subsidy expenditure by the state and it used to be regulated differently. Nowadays, subsidies are obtained through a bank and it is voluntarily to take the subsidies. In the traditional urban renewal programmes of the 1980s in Berlin, it was completely different. The subsidies were paid and the landlord was forced to renew the housing with the subsidies. Therefore, you had the rent obligations, a social regulation that is nowadays no longer possible because we now have the principle: public money for public buildings, private money for private buildings. This means that with regards to the provision of housing there are no state subsidies anymore. None might be exaggerated, but only very few; in the 
domain of energy efficiency upgrades and housing suitable for elder people, but these subsidies are very limited and therefore have practically no effect on the rent level." (Deputy managing director of an umbrella tenant organisation, ID 6)

As this deputy managing director mentioned, there were new forms of subsidies, predominantly for energy-efficiency upgrades and for the modernisation of housing to make it suitable for elderly people. These subsidies in form of a credit at a subsidised interest rate were distributed and administered by the Investment Bank Berlin (IBB) in collaboration with the KfW bank (Kreditanstalt für den Wiederaufbau). The former offered promotion programs with low interest credits. $^{137}$

Compared to the influence that subsidies had on rent levels during the early phase of the urban renewal programme, these newer forms only had a minor impact. The subsidies were not mandatory for the renovation of certain housing units. Housing providers were therefore free to decide if they wanted to make use of this subsidisation programme that was coupled with certain conditions. Stateowned housing companies accessed these subsidies more than value added investment funds. However, both emphasised that a decision to access the subsidies was only made after a cost-benefit analysis. A representative of a stateowned housing company described their decision-making process:

"These subsidies do play a role and we will access them for the block we start renovating this year. However, there is always the question if it is worth to receive the credit at a subsidised rate. On the one hand, there is an administrative work that accompanies it. On the other hand, we have to transfer the subsidy to the rent levels. And since we want to keep the social structure or even improve it by attracting a better off clientele, the lower rent levels are not always wished for." (Head of a customer service centre for a state-owned housing company, ID 24)

In cases where housing companies saw possibilities to increase rents to profitable levels, the subsidies were not very attractive because it could constrain possible profit maximisation. Value added investment funds were even more reluctant to access the subsidies. A statement from a portfolio manager of a privatised housing company reflected this attitude:

"Yes, subsidies do play a role. That is, we always examine the subsidies program if it fits our investment portfolio. For example, if the subsidy programme only supports one aspect, we however aim at a complete renewal; it is often not worth to apply for it. To summarise though, we examine each time, but we do not often

\footnotetext{
${ }^{137}$ See Investitionsbank Berlin (2011) for more details.
} 
access them." (Portfolio manager of a private housing company, ID 12)

In the cases where state-owned housing companies or private investors accessed the subsidies, the regulatory conditions were not constraining enough for the subsidies to have a relevant impact on rent levels. Housing companies that decided to make use of these programmes had to convey the difference of the subsidised interest rate and the capital market interest rate onto the tenants' rent. However, the difference between the subsidised and the capital market interest rate was too small to have a major effect on rent levels. Furthermore, several informants indicated that investors often did not pass this reduction onto tenants because there was no control mechanism in place and the administrative effort was too cumbersome. A project manager who renovated a housing estate on behalf of an investor illustrated this point:

"There was a conflict with my employer concerning the transfer of the interest advantage from the KfW-subsidies to tenants where I said, either we do this or I am leaving this job. It is unbelievable that the KfW provides subsidies, and the law regulates the transfer of the interest advantage onto the rents, but there is no one who controls it." (Former project manager for the development of a housing estate employed by an asset management company, ID 13)

The way these alternative forms of housing subsidies work was not attractive enough for investors' with regards to their cost-benefit analysis. At the same time, when the subsidies were used and the regulatory conditions implemented, they were not effective enough for tenants because of the small difference it made to their rents.

The three phases of Berlin's urban renewal programme confirm a transformation towards a more entrepreneurial form of housing renewal. The first phase that was analysed shows that the state focused on the improvement of the physical condition of the old housing stock through a state-subsidised urban renewal process that was linked to restrictive rent levels. State-owned housing companies, at that time the major player in urban renewal, operated within particular regulations that guaranteed the financing of urban renewal, but were also hindered from maximising profit. The second phase marked the radical departure of the initial urban renewal programme: It aimed to attract both private capital into neighbourhoods and "socially stabilised families" (Senatsverwaltung für Stadtentwicklung, author's translation). Housing providers, then mostly smallscale private investors, increasingly worked under market conditions, pressured to make high returns on their housing renewal investment. These investors capi- 
talised on an existing rent gap and increased rent levels. The third phase of urban renewal continued the changes made in the second one by completely abandoning urban renewal subsidies. Housing providers, and now increasingly value added investment funds, but also state-owned housing companies invested, managed, and exchanged the housing according to their strategic goals established in the previous chapters 5 and 6 .

The radical break towards a more entrepreneurial form of housing renewal took place within the second phase. However, the analysis shows that there is a continuous reconfiguration and a particular mode of social regulation is always only temporary. It is this continuous process between the particular form of regulation and production, and how these relations play out under temporal and spatial circumstances, that is crucial to understanding uneven processes. In the case of the reconfiguration of the urban renewal programme, there was a continuous process towards a more entrepreneurial form, whereas the contingently emerging production mechanisms of state-owned housing companies and value added investment funds were less and less constrained by regulatory conditions. This reinforced the revalorisation of the $19^{\text {th }}$-century block developments considered as having development potential, especially where a rent gap can be capitalised upon.

The reconfiguration of the urban renewal programme towards creating incentives for investment shows that the interplay between the production and regulation mechanisms created gentrification in the designated neighbourhoods. This underlines the argument that gentrification is not solely an effect of production (rent gap), but also the consequence of an entrepreneurial policy regime (Lees 2003, 2008). Through this more entrepreneurial policy regime, the government of Berlin achieved the goal of modernising these districts and improving their competitive position. It however also created a more exclusionary form of consumption within these housing units. The next section turns towards an analysis of the consequences on consumption.

\subsubsection{Consumption of Urban Renewal Housing}

The production mechanisms under the urban renewal regulatory changes have influenced, in turn, the consumption of aggregated demand with regards to income and household structure. The following section addresses the question: How does the demand of different types of income groups and types of household structures shape the process of uneven development under the regulatory conditions of urban renewal? 


\section{Direct and exclusionary displacement of low income households}

The new rent levels for urban renewal designated areas - that were based on the rent mirror - generated increasing financial pressure for low income households. Even though existing tenants were protected from arbitrary rent increases, the legitimate increase after every rent mirror evaluation resulted in the direct displacement of households that could no longer afford the rents. This type of displacement especially occurred in the inner city areas of West Berlin which largely still benefitted from the early urban renewal programmes. Before urban renewal, immigrants and other low income tenants such as students and retirees who were not able to move into the new social housing in the outskirts occupied the rundown dwellings (see chapter 4). These tenants could no longer afford to live in the old housing stock. With the renovation of the housing units, tenants often had to move out and even though they were entitled to re-occupy the former apartment after renovation, they could often not afford the higher rent. Some housing units were still bound to allocation regulations where only tenants with a housing voucher were entitled to move. However, housing vouchers are not only reserved for the poor. ${ }^{138}$ Even though the landlord had to rent out the newly renovated apartment in urban renewal areas to households with vouchers, the rent levels hindered the in-movement of the poor.

As mentioned, in East Berlin's urban renewal designated neighbourhoods, the rundown dwellings were either vacant or occupied by a well-educated middle class. Direct displacement played a less important role. However, more dramatic in these neighbourhoods was the type of displacement Marcuse (1986) calls exclusionary displacement (see section 2.2.4). This means that low income households were excluded from moving into this area because of increasing rent levels. This process, which happened in both East and West Berlin, was even more accelerated once the designated urban renewal area was released from its urban renewal status and the housing became excluded from any regulatory bindings. An urban renewal consultant, who experienced the urban renewal process from the beginning to the end and who was still working on the development of the neighbourhood, explained:

"For 25 years this neighbourhood was an urban renewal area [from 1979 to 2003]. 75 percent of the housing stock in this

\footnotetext{
${ }^{138}$ A single person household in Berlin is entitled to a housing voucher if their net income is below 16,800 Euros per year (Senatsverwaltung für Stadtentwicklung 2010c). The average net income per person in Berlin is 15,342 Euros a year (Statistische Ämter des Bundes und der Länder 2008). Thus, even single households, which have a net income slightly above average, are entitled to a housing voucher.
} 
neighbourhood is now renovated and modernised. In the meantime, many of the original tenants have however been displaced. We were in charge of creating social plans during the time of the urban renewal programme. The displacement of the tenant only took place after the neighbourhood was released from the programme. [...] The negative impact of the renovation process is felt now, years later, but in a very cruel way." (Collaborator of a tenant consulting service, ID 19)

The combination of deregulated rent limits and modernisation increasingly created expensive residential areas. Allocation regulations, where they still existed, did not have a great impact because they not only applied to poorer households. While low income households were displaced, middle and upper income households moved into the urban renewal housing.

\section{Increasing demand of middle class households for urban renewal housing}

The investment into the designated urban renewal areas created islands of nicely renovated housing units reserved for the expanding national and international middle class.

"The neighbourhood is very popular and the latest studies have shown that the people who are financially strong, make up a growing part of the population in the neighbourhood. This development was certainly initiated by the designation as an urban renewal area." (Head of an urban renewal division within a district administration, ID 18)

At the same time, the increasing demand for dwellings in the old housing stock of inner city areas propelled housing providers into further investment. New rounds of investment however not only took place in the urban designated areas, but also in neighbouring areas (see section 7.2.3).

The reconfiguration of urban renewal towards a more entrepreneurial form prioritised the investment of private capital over the protection of more vulnerable tenants. It generated the social exclusion of poorer households in inner city neighbourhoods because housing providers were no longer restricted in the way they operated on Berlin's housing market. The contingently emerging production mechanisms that created processes of uneven development (see chapter 5 and 6) were therefore reinforced. The following section recaptures the key mechanisms and analyses their spatial outcome. 


\subsubsection{Synthesis of Key Mechanisms in Urban Renewal Housing and Their Spatial Outcomes}

The reconfiguration of the urban renewal programme created an accelerated revalorisation process of inner city areas. The abandonment of direct state subsidies linked to rent ceilings in favour of tax incentives for private investment generated a fast paced modernisation process. This was partly influenced by specific historical circumstances. After reunification, investment became attractive again and private housing providers could capitalise on the rent gap due to the neglect of the old housing stock in East Berlin's inner city during the GDR era. Private investors, at the time small-scale, used possible tax deductions to modernise the $19^{\text {th }}$-century block developments and increased rents, which were no longer limited according to predetermined levels. The production mechanisms, combined with the reconfiguration of the urban renewal programme created two processes: On the one hand, the private investors' strategies under the particular regulatory conditions improved the old housing stock. On the other hand, these strategies created a socio-spatial segregation where low income households were displaced and middle class households moved in. The following two quotes illustrate this process:

"This urban renewal area is a success because we achieved a technical renovation coupled with social development. We didn't achieve everything we wanted, but look at the cars that are parked outside and the streets etc. At least we marked the territory in a way that people highly identify themselves with the area, that they enjoy living here and that people who don't live here would like to move here. Furthermore, this area is also profitable for us." (Technical project manager of a state-owned housing company, ID 20)

"The area is a great success from an urban development point of view. From a social perspective however, it is not successful." (Collaborator of a tenant consulting service, ID 19)

These mechanisms not only affected the designated urban renewal areas: With tax incentives, the urban renewal programme generated investors' interest and sparked the renovation process of rundown inner city areas. Due to the increasing demand and the attractive investment conditions described above, investors also started to modernise the housing stock adjacent to the urban renewal areas. 
The development of urban renewal designated neighbourhoods fostered investment in the surrounding areas. Investors, in this case value added investment funds and state-owned housing companies, renewed the $19^{\text {th }}$-century block developments without urban renewal tax incentives, without the need to apply for planning permission, and no need to adhere to rent and allocation rules.

The islands of nicely renovated housing expanded, extending even beyond the $19^{\text {th }}$-century block developments. Investors also started to target the Twenties and Thirties row developments (see chapter 4 ) adjacent to the $19^{\text {th }}$-century block developments. Because these row developments were centrally located and were increasingly celebrated for their architectural style, they became the new target for modernisation. Map 7.1 shows the old and current renewal areas; the revalorisation processes also took place around each of the renewal areas.

\section{Map 7.1: Current and Former Urban Renewal Areas in the Inner City of Berlin}

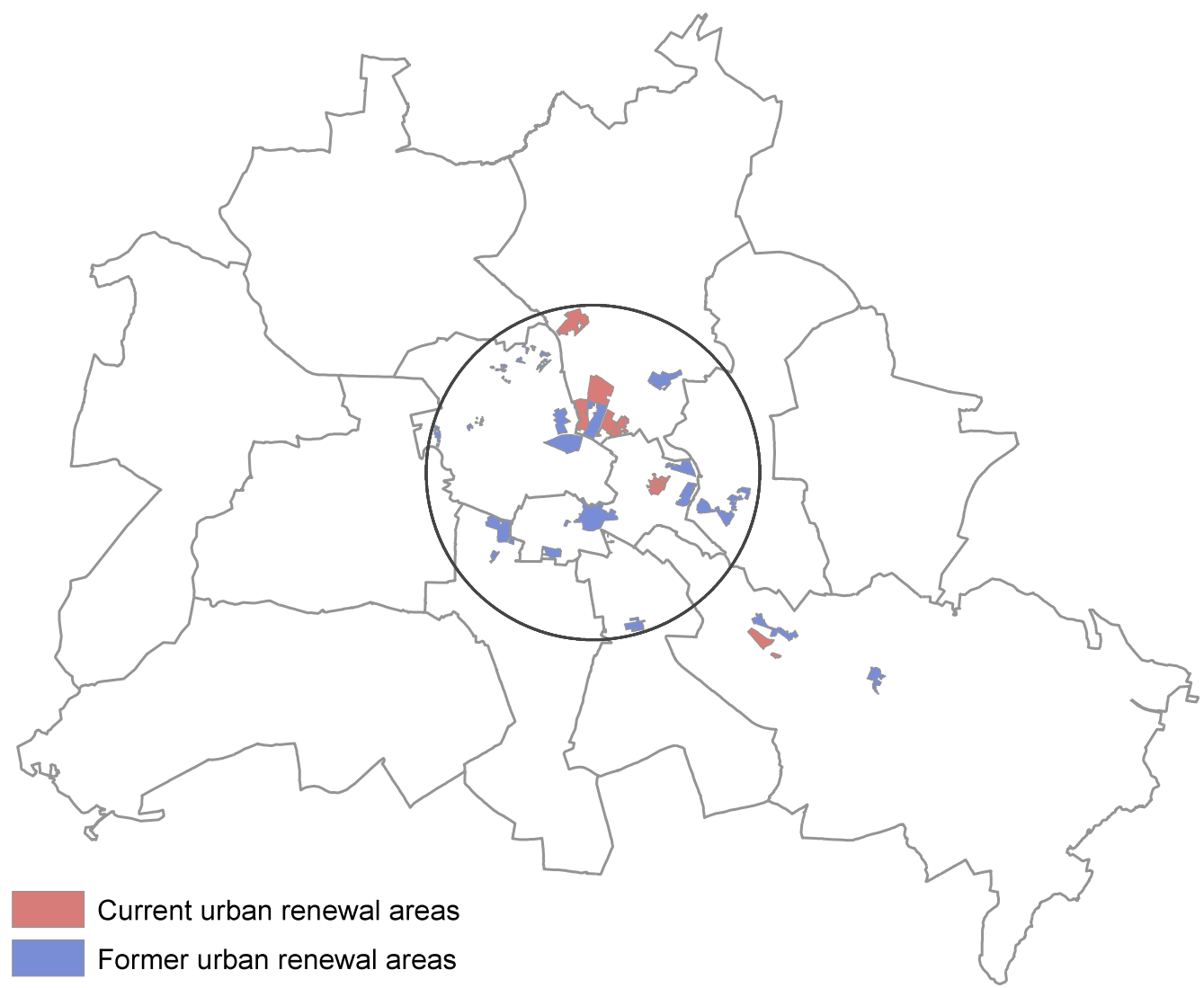

Data set: Informationssystem Stadt und Umwelt (ISU) der Senatsverwaltung für Stadtentwicklung Berlin 
Throughout the upgrading process of whole districts, the few subsidised housing units located in the designated urban renewal areas still under rent and allocation rules were relatively irrelevant. A district politician explained:

"The effect is that even though a lot of state money was invested, an apartment in Prenzlauer Berg is no longer affordable for the tenant with an average income. This process became apparent relatively early on. Yes, you receive the housing unit that has been subsidised relatively cheap. However, everything that is surrounding the subsidised housing, you can no longer afford. Prenzlauer Berg has 150,000 to 170,000 inhabitants, if you have a few thousand subsidised housing units, then this is okay, but it's not very much." (District councillor for urban development, ID 11)

The mechanisms of direct and indirect displacement were amplified in the surrounding areas because the housing outside of the designated urban renewal areas were under no specific regulatory constraints. The analysis thus shows that the state sponsored and enabled, through its particular reconfiguration of urban renewal, the gentrification of whole neighbourhoods.

Berlin's reconfiguration of urban renewal marked a more entrepreneurial form of housing provision, shaping processes of uneven development. Duncan and Goodwin (1988: 41) argue that local levels of regulation contribute to this differentiation due to the specific way in which the local level transforms specific state regulation based on their representational and interpretative role (see also section 2.1.3). In comparison to other lower state levels (Duncan and Goodwin 1988), district governments in Berlin have however little room for manoeuvre in the implementation and filtering of Berlin's regulatory conditions. Nevertheless, there were differences among districts, which emerged from the analysis. In a final section, the analysis thus turns to the lowest regulatory state level and explores the districts' influence on the entrepreneurial form of housing provision and the processes of uneven development.

\section{District governments' local mode of social regulation}

Berlin is divided into twelve districts (Bezirke), representing the lowest level of government. ${ }^{139}$ The districts in Berlin do not play the same role as communities in other German provinces (Länder), thus they do not have the same influence on housing provision. Compared to other communities, the districts also do not have their own income streams, but receive their income from Berlin's city gov-

\footnotetext{
139 The 12 districts were established with the reformation of the administration of Berlin in 2001 (Verwaltungsreform). Before there were 23 districts; 11 in East Berlin and 12 in West Berlin.
} 
ernment. This further limits their power to influence the housing provision, but they have certain influence through planning regulations.

Some districts that were heavily affected by the mechanisms analysed above selectively deployed planning tools to challenge the new regulatory conditions set by Berlin's government. As Map 7.2 shows, there were predominantly two districts - the most affected ones - that applied these measures. Moreover, there was a relatively high degree of resistance to the upgrading of these two districts. ${ }^{140}$ The following quote further showed that districts were guided by their representational function.

"The districts' interests differ from the ones of Berlin's government. The estate with 1,800 apartments that got modernised is a very small portion of the two millions apartments in Berlin. The estate is therefore uninteresting to Berlin's government. However, it is interesting to us because it affects our electorate. This is also why the tenants approached us. We have a resident question period at the district assembly and the tenants asked us how the district can possibly accept what happens." (Urban planner, member of a district parliament and head of the district's urban planning commission, ID 15)

Three intervention mechanisms could be observed in these districts: The attempt to cap rents to a certain level, the designation of milieu protection areas, and the restructuring ordinance.

To counter the accelerated increase of rent levels, the districts tried to reinstall predetermined caps on rents as a condition for planning permission in designated urban renewal areas. By doing this, they tried to counter the consequences of Berlin's reconfigured urban renewal programme which abandoned the predetermined rent limits and therefore enabled housing providers to increase rent levels according to the rent mirror (see section 7.2.1). After a judicial proceeding, the Federal Administrative Court however prohibited the caps on rents in these urban renewal areas. This put an end to the districts' interpretative role on rent regulation. A district representative who is responsible for urban renewal areas considered this a big problem:

"In the formerly eastern part of our district, we have negotiated rent caps with the developers since 1995 . However, with the decision of the Federal Administrative Court [in June 2006], this regulatory mean was taken from us, so we are no longer able to link the renewal with certain rent levels. This is a big problem."

\footnotetext{
${ }^{140}$ Both districts have a tradition of having resistance movements. The majority of the cars burnt (see chapter 1) were in these two districts.
} 
(Collaborator of an urban renewal division within a district administration, ID 18)

District governments could not filter the new regulations, but could only retroactively try to stop some of the consequences of the production and consumption mechanisms under Berlin's new regulatory conditions. Since the decision made it impossible to interfere in rent levels, districts instead deployed designation of milieu protection areas and the restructuring ordinance.

As Map 7.2 shows, the two district governments designated several of their neighbourhoods as milieu protection areas. The milieu protection area could be applied to any neighbourhood in danger of accelerated upgrading and forcing developers to apply for planning permission. This was however often only an administrative procedure; if it was not something extraordinary in comparison to the housing standards of the surrounding area, planning permission had to be granted anyway. The designation of neighbourhoods as milieu protection areas was only a retroactive policy. Districts did not apply it to areas where renovation had not taken place yet because they also desired modernisation of their housing stock. There was a fine line between their goal to improve old housing stock conditions and their goal to prevent tenant displacement. When they designated an area, the milieu protection often came too late. Since urban renewal areas had already been modernised to high standards, the districts had to approve planning permission for the modernisation of adjacent housings despite milieu protection.

A respondent pointed to the weakness, but believed it was better than nothing:

"The instrument of milieu protection areas is too weak. It doesn't help to stop the displacement of tenants. The only thing that you have to do now is to ask for permission if you want to add, for example, a balcony or a lift in the building. Then it will be examined if tenants can afford it. But basically, it's just a very bureaucratic instrument. Nevertheless, I am glad that this area here is a designated area." (Collaborator of a tenant consulting service, ID 19)

The designation of a milieu protection area could therefore only slow down the general trend of revalorisation, but could not halt it. 


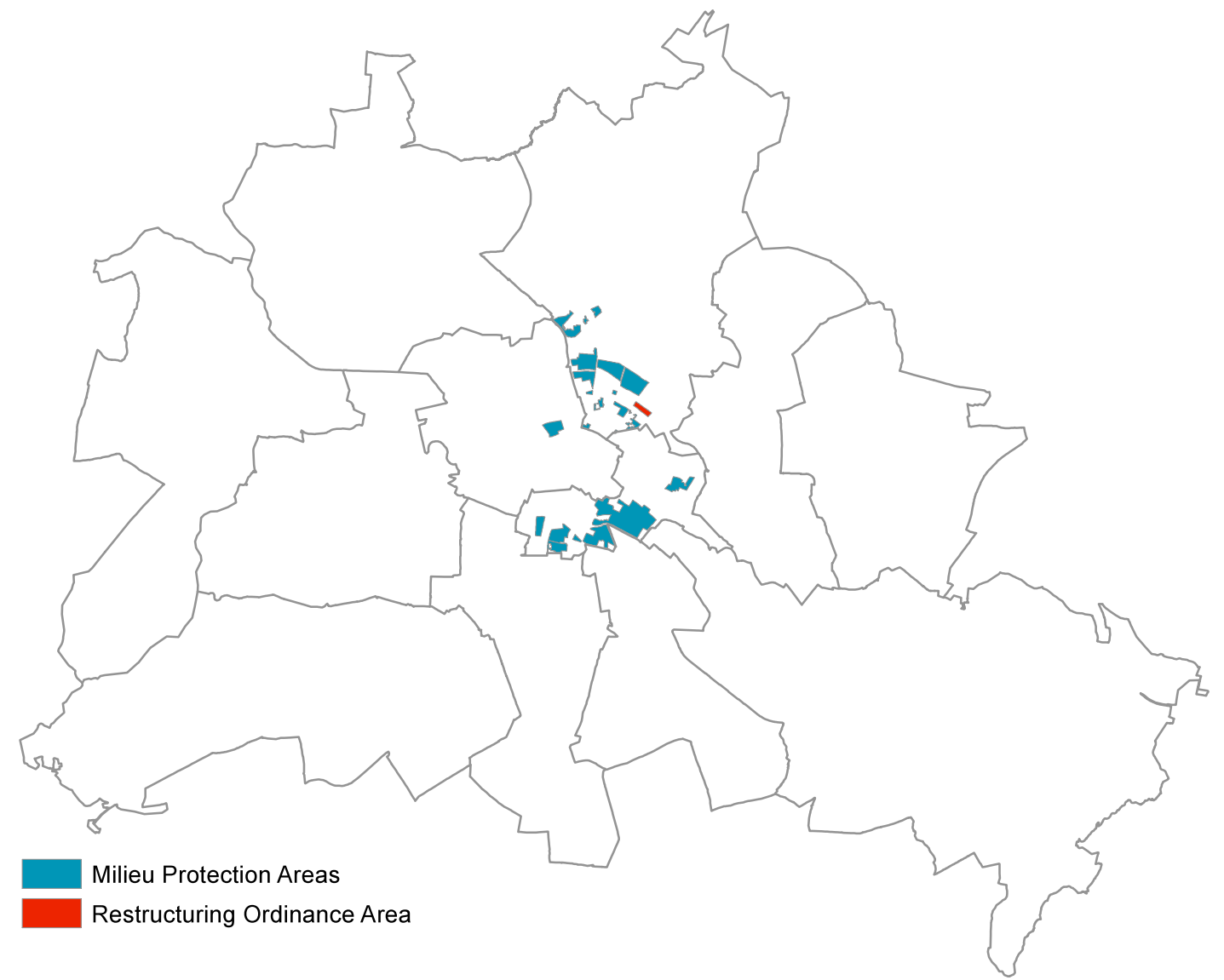

Data set: Informationssystem Stadt und Umwelt (ISU) der Senatsverwaltung für Stadtentwicklung Berlin

In comparison to milieu protection, the restructuring ordinance had only been applied once (as shown in Map 7.2). District governments could apply a restructuring ordinance to specific estates that were about to be modernised. This ordinance forced the developer to grant existing tenants the right to stay within the housing even if they could not bear the modernisation costs. It therefore directly interfered in the process of displacement that would otherwise happen. This intervention strategy was relatively strong because when applied, it actively shaped production mechanisms. However, the tool could only be applied once a modernisation process was announced. In contrast to the milieu protection area, the restructuring ordinance could not be deployed preemptively. Often, the intervention came too late because when planning permission was not needed, the district was not always aware of the modernisation process.

In the case where the district government applied this restructuring ordinance, tenants of the estate who got a modernisation notice approached the district government. The district government only reacted after pressure from the tenants as 
well as the district parliament. In cases where the district government did not take note of the modernisation process in advance because there was no tenant resistance or no planning permission needed, it could not interfere in the process.

"Often, the district finds out too late about the modernisation process, because modernisation outside of milieu protection and urban renewal areas does not need planning permission. In our case, the district found out because the tenants fought against the modernisation. Furthermore, the housing company needed planning approval because one of the blocks was under heritage protection." (Urban planner, member of a district parliament and head of the district's urban planning commission, ID 15)

The restructuring ordinance was also limited to the existing tenants. The social plan that granted tenants the right to stay within the housing did not prevent the upgrading of other housing units. This therefore still excluded lower-income households from moving into the vacant housing units after modernisation. In cases such as, for example, the estates of the Twenties and Thirties row developments in inner city areas where there was a high degree of vacancies before renovation due to the deplorable condition the restructuring ordinance had only a temporary effect for the remaining existing tenants. These developments created enough demand after renovation that under the existing regulatory and production mechanisms, an upgrading process with exclusionary displacement was inevitable.
"The estate is now renovated and there is no further investment needed, which would drive the rents up. However, we are not able to prevent the area from further appreciation, not least be- cause of the demographic structure of the tenants of the estate. There are many older tenants and when they die, which is inevi- table, new tenants will move in who pay higher rents which in- creases the standard of the estate." (Urban planner, member of a district parliament and head of the district's urban planning commission, ID 15)

The analysis shows that district governments' room for manoeuvre was limited. They could rarely challenge Berlin's transformation towards a more entrepreneurial mode of housing provision, because the district governments' did not have the capacity to interfere in the production mechanisms of housing provision. Instead, districts could only try to retroactively slow down the outcomes of uneven production mechanisms under the particular state regulations and the market conditions. In contrast to Duncan and Goodwin's (1988) analysis of councils in the United Kingdom, the interpretative and representational role of districts in Berlin is marginal due to limited regulatory means. 


\section{Conclusion}

The abandonment of supply-side subsidies for social and urban renewal housing analysed in this chapter distinguishes Berlin's further transformation to a more entrepreneurial form of housing provision. The abandonment of subsidies for social housing construction and the reconfiguration of the urban renewal programme mark the rollback of the state in favour of private investment in housing provision. In addition to this, Berlin's government also reduced its influence in regulating rent limits and allocation. The regulatory conditions explored in this chapter created constraints and opportunities for housing providers, which reinforced the processes identified in previous chapters.

The abandonment of follow-up subsidies for social housing put financial constraints on housing companies. Since it was not possible to raise the rent to the intended cost efficient levels, housing companies suffered from an income gap that prevented them from modernising unprofitable housing units. The analysis shows that housing providers were unequally affected by these conditions. Moreover, based on their finance and investment relations, housing providers employed different strategies to deal with the subsidy gap. The housing companies that primarily owned social housing were most affected by the abandonment of social housing subsidies. State-owned housing companies and social housing companies, both of which still adhered to their mandate of providing housing for low income households, cross-subsidised it with more profitable housing. Value added and opportunistic investment funds, which were tied to their return on investment targets, divested this unprofitable type of housing or neglected it. The consequence was a concentration of households on welfare in certain housing estates.

At the same time, the reconfiguration of the urban renewal programme towards supporting private capital investment into the renewal of the housing stock created opportunities for investors. Private and increasingly value added investment funds, but also state-owned housing companies, revalorised the $19^{\text {th }}$-century block developments in inner city areas. With the abandonment of urban renewal subsidies and the deregulation of rents that came with it, regulatory constraints dissolved. The revalorisation process of housing with development potential was therefore accelerated. As a consequence, low income households were directly displaced or could no longer move into these areas. These processes led to islands of modernised housing occupied by wealthy people. 
The analysis in this chapter underlines the argument that it is the particular coupling of regulation and production mechanisms that create processes of uneven development. This chapter shows that state regulation influences production mechanisms. The mechanisms state regulation triggers are however often unintended, because it does not know how particular regulations, such as the abandonment of supply-side subsidies play out in a specific context. Thus, the abandonment of supply-side subsidies affected social housing differently than urban renewal housing, even though the abandonment meant that both housing types became increasingly integrated into free market mechanisms.

This chapter, and those preceding it have demonstrated that a critical realist examination of the uneven processes of Berlin's provision of housing structure allows for a better understanding of how the three forms of reorganisation - the privatisation of state-owned housing, the reformation of state-owned housing companies, and the abandonment of supply-side housing subsidies - triggered mechanisms within the provision of housing structure that leads to a process of social and spatial inequality. The analysis went beyond a confirmation of Berlin's move towards a more entrepreneurial city within the domain of social welfare provision. Moreover, the analysis shows that entrepreneurial housing provision is struggled for and takes many different forms. Exploring the contingently emerging production and consumption mechanisms, the analysis shows how these mechanisms work with and against existing and changing state regulations in specific market conditions. The analysis therefore provides empirical explanations for how a new mode of social regulation takes place under specific conditions and how it creates processes of uneven development.

The following concluding chapter of the thesis, turns towards a discussion of what these results mean for the understanding of regulation theory, the entrepreneurial city, and uneven development, arguing that these theoretical approaches have to incorporate a more finely tuned analysis in order to explain the mechanisms between a new mode of regulation such as the entrepreneurial city and the social and spatial inequalities it triggers. 


\section{Conclusion}

The Introduction to this thesis stated two aims: First, to contribute to the theoretical debate on uneven development by investigating how a particular mode of social regulation creates socio-spatial inequalities at the urban level. Second, to add to the debate of Berlin's urban development over the last decade through an understanding of the city's mode of housing provision. The question the thesis thus addressed was: How have the transformations of Berlin's mode of housing provision generated particular spatial and social inequalities?

With the purpose of researching this question, I engaged with a specific approach to regulation theory which is concerned with the transformation of the local state and its impact on spatial development. I argued that a specific mode of regulation comes about through crisis resolutions struggled for, and moderated by, the state. This crisis resolution is an ongoing process of (re-)regulation. In this sense, regulation theory was not used as a means to search for an ideal type institutional fix, but as a tool to investigate the processes of regulatory changes. Within this approach, I argued, uneven development emerges due to tensions within and between existing distinctive local modes of social regulation, which can be identified at all spatial scales. I then defined the current historical-specific mode of regulation at the urban level as the entrepreneurial city. Within this context, the entrepreneurial city regulatory form is characterised by a transformation from public-led welfare provision to the prioritisation of economic growth policies creating social and spatial inequalities.

I argued - applying a sympathetic critique towards regulation theory and the entrepreneurial city debate - that both, regulation theory, and on a more concrete level the entrepreneurial city, tend however to be over-deterministic. In doing so, they fail to account for the multidimensionality of the transformation process of a particular mode of social regulation. Through this normalisation "for the specificity of outcomes" (Massey 1984: 6), regulation theory misses, or underplays, a causal explanation for why and how processes of uneven development occur due to the particular modes of social regulation. Accordingly, in order to understand the processes of uneven spatial development generated through an entrepreneurial mode of social regulation, I strongly argue in favour of a more specific conceptualisation of possible processes. As Peck (2003: 223) states:

"The task of theoretically informed research on state restructuring has to extend beyond mere reaffirmation of these received categories (or worse still, the indiscriminate relabeling of mundane policy shifts in such terms, as if this itself con- 
stituted an 'explanation'). Not only must the categories themselves be subject to critical scrutiny, but carefully formulated empirical work is required in order to expose underlying patterns and processes, and to generate critical cases and counter-cases." (Peck 2003: 223)

Taking up Peck's challenge, and extending it further I used a critical realist methodology to "carefully formulate the empirical work". Through a critical realist approach, the thesis therefore overcame a "stylized reading of processes like 'deregulation, 'privatization', 'neoliberalization"', but instead investigated the "underlying patterns and processes" (Peck 2003: 223). A critical realist approach helped to establish coherent causal mechanisms for explaining why and how a particular mode of housing provision creates processes of uneven development.

The thesis therefore provides the tools to better understand the underlying processes and relationships between the transformation of Berlin's mode of housing provision and their consequences of spatial and social inequalities at particular points in time. Accordingly, the thesis contributes to the creation of new empirical knowledge. The thesis is however not only an empirical study of Berlin's mode of housing provision; by integrating a critical realist methodology with a state-centred regulation theory, the thesis contributes to a re-conceptualisation of the entrepreneurial city and uneven development, which helps to better understand how and why a specific mode of regulation negotiated through the state creates processes of uneven development. The way I took a critical realist position and developed it in the particular context and practices of housing provision has enabled me to demonstrate unique insights into Berlin's housing provision, but also - more generally - into understanding how uneven spatial development is produced and intertwined with state restructuring.

Based on the analysis of the transformation of Berlin's mode of housing provision, this concluding chapter revisits the theoretical concepts. Given the significance of this conceptual innovation, the chapter discusses how a critical realist analysis contributes to regulation theory through a re-conceptualisation of the entrepreneurial city and uneven development. The chapter starts with a discussion on the integration of a critical realist methodology and a state-focused approach of regulation theory (8.1). Section 8.2 discusses how this critical realist methodology contributes to the re-conceptualisation of the entrepreneurial city as a starting rather than an end point of research. The section further illustrates why this re-conceptualisation contributes to a better understanding of state restructuring and its uneven consequences. Section 8.3 reflects on the re-conceptualisation of uneven development as a process instead of an outcome, discussing its impact 
beyond this thesis. In a further section (8.4), the chapter discusses the empirical contributions of the thesis, emphasising how the conceptual innovation contributed to a better understanding of the regulatory changes of Berlin's mode of housing provision. The final section of the chapter (8.5) points to some of the research gaps revealed and discusses possible leads for further research.

\subsection{Regulation Theory, the Role of the State, and Spatial Division of Labour}

In the Introduction to the thesis I argued that a state-focused approach to regulation theory proves to be most useful to understand regulatory changes at the local scale due to its theorisation of the state through which local modes of social regulation are negotiated and moderated. Moreover, the more concrete concept of the entrepreneurial city helped to identify regulatory changes in the mode of housing provision focusing on the role of the state. At the same time, I rejected Massey's (1984) concept of spatial division of labour for understanding the transformation of Berlin's mode of housing provision and the uneven development as a starting point. I argued that the spatial division of labour underemphasises the role of the state. Later, it was stated that Peck and Tickell (1995: 26 et seq.) argue for an integration of Massey's (1984) concept of spatial division of labour in order to integrate sub-national economic spaces into the analysis. In doing so, Peck and Tickell (1995: 26 et seq.) state that regulation theory can take account of the local state as a necessary product of the division of capitalist production systems and its uneven development. This line of argument does however, as shown, not entirely solve the problem of an overly deterministic conceptualisation of uneven development as an outcome and does not account for the processes of how uneven development emerges.

Here I argue that regulation theory is a valid starting point for understanding processes of regulatory changes. However, instead of a stylised integration of Massey's concept of spatial division of labour as proposed by Peck and Tickell (1995: 26 et seq.), it is Massey's critical realist thinking, and more specifically her critical realist methodology, which should be integrated into a regulation theory based analysis. While regulation theory claims to be based on realist ontology (Jessop 1990a), research by regulation theorists has rarely been taken far enough to integrate realism as a methodological approach. It is thus here, where critical realism makes the most valid contribution to regulation theory. A critical realist approach to regulation theory minimises the shortcoming of the overly deterministic conceptualisations of entrepreneurial city and uneven development (see below 8.2 and 8.3). 
Using a critical realist methodology, the thesis is thus close to Massey's (1984; Massey and Meegan 1982) conceptualisation of uneven development. ${ }^{141}$ Massey and Meegan (1982) argue in their investigation of the unevenness of job loss in different sectors of the British economy during the early 1970s that the particular causal mechanism for job loss, such as technical changes or rationalisation, generated different spatial outcomes. Thus, it is the particular way the companies worked and their effect on the existing environment that defines the uneven development process. In contrast to Massey and Meegan (1982), this thesis however integrates critical realist methodology with regulation theory's specific focus on state restructuring. Moreover, the thesis explores the particularities of the housing provision and its uneven development process, therefore investigating a specific sector and its impact on the built environment.

The following two sections re-examine the concepts of entrepreneurial city and uneven development, explaining how critical realism contributes to a better understanding of how and why a particular mode of regulation creates processes of uneven development. Critical realism as a methodology (see Pratt 1994) contributes to regulation theory and the entrepreneurial city debate respectively, and their conceptualisation of uneven development: First, realism addresses the issue of scale by shifting from abstract to concrete and from concrete to abstract. It therefore avoids an overly deterministic analysis of a particular mode of social regulation without falling into the trap of empirical particularities. Second, realism shifts from an understanding of uneven development as the outcome of different modes of local regulations to an open understanding of uneven development as continuous and continuing processes.

\subsection{The Entrepreneurial City Re-examined}

Based on the review of the theoretical literature (see chapter 2) on the entrepreneurial form of urban governance, I defined the concept of the entrepreneurial city according to three characteristics. First, the local state's emphasis on economic growth oriented policies coupled with a withdrawal from the sphere of welfare provision; second, the institutional transformation from state-directed to private-led policy formulation and implementation; and third, the increasing socio-spatial inequality as a consequence of the transformation. This conceptualisation of the entrepreneurial city is useful in identifying current regulatory changes at the urban scale. The changing priorities from welfare to economic devel-

\footnotetext{
${ }^{141}$ While she mostly avoids the realist language in her best-known work 'Spatial Division of Labour' (Massey 1984), she clearly adheres to a realist approach and explicitly does so in her earlier work, such as the 'Anatomy of Job Loss' (Massey and Meegan 1982).
} 
opment can also be observed in the domain of housing provision. With regards to the provision of housing, urban entrepreneurialism is understood as a withdrawal from public-led housing provision such as the privatisation of state-owned housing. At the same time, an entrepreneurial form of housing provision aims to attract private investment through growth oriented policies such as tax incentives. The consequences of a more entrepreneurial form of housing provision are exclusionary spaces for the rich, in form of gentrified or gated neighbourhoods and increased socio-spatial inequalities.

However, as pointed out in chapter 2, this conceptualisation of the entrepreneurial city does not account for the multidimensionality of causal mechanisms triggered by a transformation of the mode of housing provision. Moreover, I challenged the usefulness of the entrepreneurial city concept to understand the processes of uneven development because the concept hides too many differentiating causal mechanisms under one umbrella. In this sense, the concept of entrepreneurial city remains 'chaotic' (see Sayer 1992: 138 et seq.) because it has no "coherent relation to causality" (Massey and Meegan 1982: 9). This is especially problematic when trying to explain the why and how of uneven development. As Allen (1987: 235) indicates, "'chaotic' conceptions are not intrinsically bad; they are only inadequate if they represent the end product of an analysis rather than the starting point." Instead of reproducing these chaotic concepts, it is however necessary to construct "a more rigorous conception" of the particular forms in which the concept such as that of the entrepreneurial city can play out in practice.

The thesis achieved this more rigorous conception with a two-step approach. First, I used the concept of the entrepreneurial city not as an end point for explaining socio-spatial inequalities, but as a starting point to identify processes of re-regulation of Berlin's mode of housing provision. Second, based on critical realism I applied a rational abstraction (see Sayer 1992: 138 et seq.) of causal relations within the processes of housing re-regulation. Informed by realist studies of housing, I abstracted causally coherent analytical categories under the banners of production, regulation, and consumption of housing.

I defined production relations as the finance, investment, management, and exchange strategies that emerge through different types of housing providers. The analysis revealed that the key to understand production relations was the financeinvestment relation, meaning that the particular type of finance determined the way housing providers invested, but also how they managed and exchanged the housing. 
These production relations are however influenced by housing regulation and consumption relations. I abstracted housing regulation as constraining or enabling rights to develop, maintain, exchange, and use housing. I further conceptualised consumption relations as the aggregate demand of users based on their income and their household structure. The production, regulation, and consumption relations interact with each other, building the provision of housing structure. This rational abstraction provided the necessary tools to reveal the uneven mechanisms that are taking place.

The emphasis of the thesis clearly based on the understanding of the production relations under the regulatory conditions they operated. I argued that the production and regulation relations were the key to understand the uneven mechanisms of the mode of housing provision. Through the empirically grounded analysis three different types of production mechanisms were identified. The value added investment fund, the opportunistic investment fund, and the state-owned housing companies. The particular way these three types of housing providers played out in relation to regulation and consumption mechanisms uncovered the uneven causal processes of a more entrepreneurial form of housing provision.

This two step approach contributes not only to a better understanding of the multidimensionality of entrepreneurial forms of urban governance, but also the uneven mechanisms of a particular mode of regulation within the housing sector. The following section shows in more detail how this innovative conceptualisation contributed to a better understanding of the re-regulation of Berlin's housing provision and its uneven consequences.

\section{Revealing the uneven mechanisms beyond the entrepreneurial city}

Derived from the conceptualisation of an entrepreneurial mode of housing provision, the analysis of the transformation of Berlin's mode of housing provision identified three processes of re-regulation: First, the privatisation of state-owned housing and the entrance of institutional investment; second, the reformation of the remaining state-owned housing companies and the newly integrated economic goals into their finance relations; third, the abandonment of supply-side subsidies for the construction and renewal of housing and the deregulation of rent and allocation rules. The detailed investigation of the three processes revealed a multitude of mechanisms underpinning the argument that it is not the more entrepreneurial form of housing provision per se, which creates the social and spatial inequalities. Instead, it is the way the housing production and consumption plays out under the specific regulatory conditions, creating intended and unin- 
tended consequences. It is only through the rational abstraction of the particular mode of housing provision that these intended and unintended consequences of the processes of re-regulation could be revealed. By this, the analysis yielded new empirical knowledge that is above and beyond what previous conceptualisations afforded. The three processes of re-regulation are briefly recaptured in order to illustrate how the empirical analysis exposed the uneven mechanisms.

First, the government privatised state-owned housing in a particular way, which facilitated the entrance of institutional investment in Berlin's housing market. The en bloc privatisation excluded small-scale investors or home ownership. It is therefore not the privatisation process nor the entrance of institutional investment that creates social and spatial inequalities - as argued by the entrepreneurial city debate but the diverging ways in which the privatisation process plays out. This type of analysis further challenges the normalised conceptualisations of privatisation and of institutional investment. Privatisation of housing in this case took a particular form that contrasts from other forms of housing privatisation such as the increase of owner-occupied housing. Institutional investment, in turn, is often insufficiently abstracted under the concept of international financial capital. Institutional investors follow diverging strategies, which are defined through their finance relations. Value added investment funds operate differently from opportunistic investment funds, due to their differing return and risk strategies. In order to understand the uneven mechanisms, it is therefore important to differentiate between diverging finance-investment relations of private-led housing provision and how they play out under different regulatory and market conditions.

Second, the particular way through which the state integrated economic goals into the guiding principles for state-owned housing companies created a specific hybrid form of state- and market-led housing provision. This uncovered mechanisms, which go beyond the old dualism of state versus market-led housing provision and showed how complex the inter-linkage between the two spheres is. The particular integration of market mechanisms into state-led housing did not turn state-owned housing companies into private investors, but created particular mechanisms between economic profit-orientation and adhering to social goals such as the provision of housing for low income households dictated by the government. The analysis of state-owned housing companies further pointed to differing mechanisms within the state-led form of housing provision. While adhering to the same finance mechanisms dictated by Berlin's government, the historical development of the different state-owned housing companies generates diverging pathways. The analysis shows that the conceptual model (see chapter 3 ) 
underemphasised the explanatory relations for these diverging pathways (see also section 8.5 below).

Third, the abandonment of supply-side subsidies for the construction and renewal of housing coupled with the deregulation of rent and allocation rules reinforced the previously established mechanisms. It showed that regulatory changes constitute opportunities or constraints for the different institutional investors and the state-owned housing companies, affecting the different market segments unequally. This shows that an increasing lack of affordable housing and the process of gentrification are not only due to the particular production mechanisms, but also a result of the particular regulatory regime.

The detailed analysis of the three processes challenged the normative notion of market versus state-led housing provision referred to in the entrepreneurial city debate. The analysis exposed a complex transformation of the old dualism between the state and the private sphere. Berlin's mode of housing provision is not a mere change from a state-led to a private-led housing provision. The particular way of the transformation created hybrid forms of housing provision. The boundaries between private and state-led housing are therefore blurred. Moreover, neither the private nor the state can be regarded as a coherent entity. Private-led housing provision takes diverse forms, depending on the specific finance mechanism of the private housing provider. The same is true for state-led housing provision. Thus, the analysis shows that a dualistic distinction between the state and the private domain needs to be abandoned in favour of a more complex analysis, which accounts for the causal mechanisms between regulation, production, and consumption.

These specific uneven mechanisms of Berlin's mode of housing provision exposed through a method of rational abstraction not only challenged the concept of the entrepreneurial city as an explanation for socio-spatial inequalities. The rational abstraction also contributes to a re-conceptualisation of uneven development as a process instead of an outcome. The following section reflects on this re-conceptualisation of uneven development, addressing its impact, which goes beyond the particularities of this thesis. 


\subsection{Uneven Development Reviewed}

The critical realist analysis of the transformation of Berlin's mode of housing provision also extends regulation theorists' conceptualisation of uneven development. Following specific regulation theorists (see chapter 2), I stated that uneven development is the spatial outcome of the temporary coupling between the regime of accumulation and the mode of regulation in a capitalist system. Moreover, uneven development emerges from "different regulatory functions" (Peck and Tickell 1995: 27), which are located at different scales. The distinctive local modes of social regulation therefore create an uneven development which is reinforced by the local state's autonomy as a regulatory agent who orchestrates uneven development. This conceptualisation, I argued, is however not able to take into account uneven development at the local scale where regulatory differences no longer play a significant role. The thesis therefore sought a reconceptualisation of uneven development as process instead of outcome. This reconceptualisation, again, came about through the critical realist methodology applied.

The causal processes that arise from the particular way the different finance and investment relations of housing providers play out in practice are inherently uneven. From this realist analysis of Berlin's mode of housing provision follows that uneven development is not a mere consequence of the mode of social regulation at a particular scale. Instead, it is the diverging finance strategies of value added funds, opportunistic funds, and state-owned housing companies that create processes of uneven development. Due to their particular finance strategy, the different housing providers follow diverging and uneven investment, management, and exchange strategies. The uncovering of these mechanisms goes beyond an affirmation of different modes of social regulation, therefore achieving a higher level of understanding of the ongoing processes between regulation, production and consumption.

The analysis thus exposed the distinctive finance and investment relations the three identified housing providers have. Value added investment funds' profit strategy is based on the modernisation of housing. They invest therefore only in the housing stock, which they believe has development potential for making profit through higher rent levels. They however abandon the unprofitable housing stock. Opportunistic investment funds have a high-risk strategy making profit through financial leveraging. They therefore buy often-unprofitable housing cheaply and try to re-sell it at a higher price. State-owned housing companies adhere to a wide range of housing types in their portfolio due to hybrid economic 
and social goals. They however prioritise investment in the housing where they see possibilities for increasing rent levels.

It is these diverging production mechanisms, emerging through the different types of housing providers that create processes of uneven development. These uneven finance and investment processes manifest themselves in the increasing social and spatial inequality of Berlin's housing provision. However, the processes of uneven development lead not to a final outcome, or spatial-fix, but are continuously reshaped. During the period of investigation, the mode of housing provision continued to be transformed through further regulatory changes such as the shift from state subsidies for housing to public infrastructure. Moreover, the market conditions were drastically changing because of the global financial crisis. It is these contingent relations, which continue to shift processes of uneven development. The social and spatial inequalities are therefore always only provisional (see Pratt 1994: 4). The reasons as to why particular providers invest and the processes of how and where they invest are therefore crucial for understanding the processes of uneven development. This raises a final question of how much the characteristics of a place - the spatial, physical, institutional, and social predispositions as described in chapter 4 - matters for an explanation of uneven development.

\section{Understanding spatial relations beyond the characteristics of a neighbourhood}

Chapter 4 argued that the uneven spatial, physical, institutional, and social context of the neighbourhood matters in order to understand subsequent processes of uneven development. Through a realist analysis, the thesis showed that the particular characteristics of a place - a neighbourhood - are however not enough to understand uneven development. It is the particular way, I argue, in which the different housing providers use these characteristics that create processes of uneven development. The characteristics of the neighbourhood matter only to the extent that they depend on the type of production mechanism that create investment or disinvestment in the particular type of housing (see also Massey and Meegan 1982: 123 et seq.).

The thesis thus confirmed that 'space matters' in the analysis of a particular mode of social regulation. More importantly, through developing the realist position in the context of housing provision, the thesis showed how space matters. The under-maintained old neighbourhoods of the $19^{\text {th }}$-century block developments in the inner city are not just invested in because there is a rent gap. It is the particular way value added investment funds, and similarly the state-owned 
housing companies, create profit through investing in this type of housing. At the same time, prefabricated high-rise housing estates from the 1970s are getting neglected due to the opportunistic investment funds' finance strategy to buy cheap and make profit on the exchange value. Opportunistic investment funds therefore poorly manage and maintain the neighbourhoods of high-rise housing estates.

The features of a particular place such as the spatial, physical, institutional, and social context of a neighbourhood have therefore only "effects via the particular objects, with causal powers, that constitute it" (Pratt 2004: 249). Spatial relations cannot be reduced to the characteristics of a place, but need to be examined with regards to how these characteristics are used by the housing providers and their financial mechanisms. The thesis uncovered the production mechanisms of housing not only in their abstract form, but investigated these mechanisms in relation to the particular conditions of the different neighbourhoods. This allowed for an in-depth understanding of how processes of uneven development play out spatially (see Pratt 2004: 249).

Logically, a further step of analysis is the question of how the different neighbourhoods shape the uneven processes. Extending on Massey's (1984: 242) point that "[...] geographical differentiation, distance and locational mobility themselves moulded, sometimes even enabled, the social and economic changes which took place" the question of the autonomy of localities argued for by Duncan and Goodwin (1988; see also Goodwin et al. 1993) becomes a more central focus to the analysis. The thesis made a start in this direction by investigating the role of particular district administrations in shaping the mode of housing provision. An exploration of the housing consumers as agents in orchestrating this process could be a further step in this direction (see also section 8.5 below). Through the critical realist model, the thesis provided the necessary tools for such an analysis.

The re-conceptualisation of the current mode of social regulation and uneven development as the particular processes taking place through objects and their causal relations has consequences on the understanding of the debate of Berlin's urban development between an entrepreneurial way and possible alternatives. 


\subsection{Berlin's Urban Development Revisited}

There is a lively debate among scholars on the way Berlin has been developing since reunification (see chapter 1). Some scholars (see, for example, Cochrane and Jonas 1999; Bernt and Holm 2009) claim that Berlin's urban development takes up a neoliberal pathway and follows other cities in its quest for economic competitiveness. Others (see, for example, Latham 2006a; Colomb 2007) point to the alternative pathways that are sought out. They emphasise Berlin as the place for alternative living strategies, and political resistance. In this sense, the analysis of the transformations of Berlin's mode of housing provision could have been interpreted as a neoliberal or entrepreneurial turn creating more inequalities. An analytical focus on resistance towards the transformations in the housing provision could however have possibly revealed alternative pathways.

Thus, the argument I make here, based on the approach developed and findings exposed in this thesis, is that in order to understand Berlin's urban development, it is not a matter of reconfirming the neoliberal or alternative pathway Berlin might have taken or will take. It is the way the particular mode of social regulation plays out in practice, the why and how of a particular form of urban governance that is important. Re-conceptualising the way in which the transformation of a local mode of social regulation is analysed by taking the concept of the entrepreneurial city as the start and not the end point, the thesis went beyond the dualistic view of entrepreneurial city versus alternative urban development model and explains how a particular mode of housing provision plays out in practice. The debate of whether Berlin converges with the neoliberal urban model or takes alternative pathways is thus not particularly useful since one always finds stylised confirmation for one or the other.

Based on the findings of the research done in this thesis, I argue therefore that research on Berlin's urban development - and, of course, urban development more generally - should focus less on reconfirming neoliberal strategies or political alternatives, but on how these strategies play out under the particular circumstances. Research thus needs to address not only the theoretical abstraction of causally coherent concepts, but also needs to investigate the particularities of these concepts under the specific contingent conditions (see Pratt 2004: 249). This means an analysis of Berlin's urban development needs to investigate the necessary relations of the object studied - as in this thesis' case the production, consumption and regulation of the provision of housing structure - and how these relations play out under specific temporal and spatial conditions. This thesis showed how such an approach contributes to a better understanding of ongoing processes of urban development. 
This thesis' innovative approach to conceptually link regulation theory, the entrepreneurial city and critical realism, and empirically investigate Berlin's mode of housing provision produced new empirical knowledge and provided the conceptual tools to understand the role of urban governance in producing processes of uneven development. The last section discusses how, based on the empirical findings, research should be taken further.

\subsection{Further Research}

The thesis' findings point to a conceptual and an empirical gap, which should be further addressed. These gaps were underemphasised in the study due to the particular aims and design of it, but will be discussed in this final section of this concluding chapter. First, as already suggested, the role of housing consumption was not a key focus of the research and therefore deserves further attention in future research on the uneven mechanisms of housing provision. Consumption relations therefore need further conceptualisation with regards to the causal processes within the structure of housing provision.

Second, the investigation of Berlin's mode of housing provision revealed not only the uneven mechanisms of institutional investment, but of the state-owned housing companies themselves. The causal relations for these mechanisms were however underemphasised by my conceptual model of the provision of housing structure due to the entrepreneurial city's debate on housing privatisation and my focus on the causal mechanisms of institutional investors. Further research should therefore take a closer look at causal mechanisms of state-owned housing companies, but possibly also at causal mechanisms of other housing providers such as housing associations.

\section{Conceptualising the role of housing consumption}

The role of consumption was conceptually underdeveloped in this thesis. I argued that consumption is shaped through the particular production and regulation relations. Consumption therefore plays only a subordinate role for understanding processes of uneven spatial development. This conceptual underdevelopment resulted in an underemphasis of the influence of consumption and the increasing and decreasing demand of different types of households; it raises the question of what role the demand side of housing plays within the provision of housing structure and its uneven mechanisms. For a better understanding of the role consumption plays within the processes of uneven development, "well-developed 
conceptual models of this complex realm, and its influence on forms of housing provision, have yet to be developed" (Lawson 2006: 75).

Lawson (2006: 76) mentions labour and welfare relations as possible leads to investigate the bargaining power of households in a specific housing market. The strand of literature on the consumption-oriented explanations of gentrification processes (Lees et al. 2008) might point to further leads, such as the political culture of consumers, gender relations, tastes, and lifestyles. Questions such as how particular groups' consumption strategies create uneven mechanisms and influence the mode of housing provision should therefore be addressed in more detail.

\section{Investigating the uneven mechanisms of state-owned housing}

Extending on the literature of the entrepreneurial city, which focuses on the transformation from a state-led to a private-led mode of housing provision and its consequences of social and spatial inequalities, the thesis focused on the investigation of the differentiated mechanisms of private-led housing provision, and more concretely on the entrance of institutional investment which took place due to the particular way Berlin's government privatised its housing stock. Moreover, the realist literature on housing (Ball 1990; Lawson 2006) emphasises the finance and investment relations as the key to understand different modes of housing provision. The thesis focus rested therefore on the different financial mechanisms of institutional investment taking place in Berlin and their uneven investment, management, and exchange strategies.

However, during the course of the research, the question arose why there are strategic differences between state-owned housing companies despite operating under the same finance relations defined by Berlin's government. The differences found, especially with regards to their social engagement, suggested that other types of relations, such as the organisational structure might also play a role in explaining different investment, management, and exchange strategies. The focus on finance relations did not seem sufficient to understand the different strategies state-owned housing companies chose to follow.

The thesis has preliminarily argued that the differing historical development of the state-owned housing companies and the specific portfolio they inherited through this historical development accounts for the distinctive mechanisms observed. The three state-owned housing companies, which were under scrutiny, might have been insufficiently differentiated to understand the relations which 
create the different strategies. Future research on the role of state-owned housing in the uneven development of the provision of housing structure should therefore address the question of whether there are other necessary relations, besides the finance-investment ones, that influence the particular mode of housing provision.

\section{Conclusion}

This thesis confirmed that the restructuring of Berlin's mode of housing provision involved a turn towards market-oriented housing provision creating sociospatial inequalities. However, in contrast to previous accounts of state restructuring, the thesis' critical realist methodology to investigate the entrepreneurial city and uneven development contributed to a more rigorous understanding of how and why state restructuring fosters uneven mechanisms, which in turn create social and spatial processes of uneven development.

The thesis constructed a rigorous empirical evidence base of Berlin's mode of housing provision and its impact on the city's urban development. Moreover, the way the thesis integrated and developed the specific regulation theory, the entrepreneurial city, and critical realism contributed to conceptual innovations. The entrepreneurial city as the current form of mode of regulation, I argued, is a starting point for understanding state restructuring, but not the end point for explaining how and why socio-spatial inequalities are created. Developing a conceptual model within the specific sector of housing, through rational abstraction, the thesis exposed the causal mechanisms and its uneven consequences that emerged from the re-regulation of a particular mode of housing provision. This allowed for a better understanding of the multiple dimensions of the particular form of urban governance. Moreover, it provided a way of re-conceptualising uneven development as a process within a specific regulatory mode rather than an outcome of different regulatory modes.

Following on from these conceptual contributions and empirical knowledge, the thesis has implications on two levels; one regarding future research on urban governance and the other on the politics of housing. First, it reassesses the way urban governance, and in particular urban housing provision, is researched. It provides conceptual tools for a more rigorous analysis of state restructuring and its uneven consequences. Moreover, the thesis proposes a particular conceptual model for theoretically informed research on the causal mechanisms of housing provision and its uneven consequences. Second, a better understanding of the intended and unintended consequences of Berlin's particular mode of housing provision exposed through this research allows for a reassessment of the impact 
of state restructuring. The thesis therefore provides not only new conceptual and empirical knowledge for researchers, but also delivers important insights to policy makers on how Berlin's housing provision, and more specifically, the particular regulations negotiated and moderated through the state, contribute to uneven development. 


\section{Appendices}

Appendix 1: Interview List

Appendix 2: Interview Guideline (German)

Appendix 3: Conference List

Appendix 4: Document List

Appendix 5: Networks of the Data Analysis

Appendix 5.1: Reorganisation of Housing Provision

Appendix 5.2: Regulation

Appendix 5.3: Institutional Investors

Appendix 5.4: State-owned Housing Companies 


\section{Appendix 1 Interview List}

\begin{tabular}{|c|c|c|}
\hline ID & Position & Date \\
\hline \multicolumn{3}{|c|}{ Administration of Berlin Government } \\
\hline 5 & Employee of the Senate Department for Urban Development & 25.6.09 \\
\hline \multicolumn{3}{|c|}{ Administration of District Governments } \\
\hline 15 & $\begin{array}{l}\text { Urban planner who is also a member of a district parliament and head of the dis- } \\
\text { trict's urban planning commission }\end{array}$ & 15.5.09 \\
\hline 11 & District councillor and his collaborator for urban development & 10.6.09 \\
\hline 17 & Deputy head and his collaborator of a district housing administration & 2.6 .09 \\
\hline 18 & $\begin{array}{l}\text { Head and his collaborator of an urban renewal division within a district administra- } \\
\text { tion }\end{array}$ & 8.6 .09 \\
\hline 22 & District councillor for social welfare, housing and environment & 10.6.09 \\
\hline \multicolumn{3}{|c|}{ Private Housing Companies and Investors } \\
\hline 12 & Chief financial officer and his portfolio manager of a private housing company & 20.7.09 \\
\hline 7 & Principal of an investment firm & 17.6.09 \\
\hline 16 & Director of a real estate fund at a bank & 12.8 .09 \\
\hline 13 & $\begin{array}{l}\text { Former project manager for the development of a housing estate employed by an } \\
\text { asset management company }\end{array}$ & 18.6.09 \\
\hline 23 & Head of public relations of a private housing company & $\begin{array}{r}13.5 . \\
09 \\
\end{array}$ \\
\hline 30 & Managing director of a property management firm & 21.7.09 \\
\hline \multicolumn{3}{|c|}{ Social Housing Company } \\
\hline 25 & Division manager and his collaborator of a social housing company & 10.7 .09 \\
\hline \multicolumn{3}{|c|}{ State-owned Housing Companies } \\
\hline 24 & $\begin{array}{l}\text { Head and his deputy of a customer service centre for a state-owned housing } \\
\text { company }\end{array}$ & 24.6.09 \\
\hline 20 & Technical project manager of a state-owned housing company & 7.7 .09 \\
\hline 28 & Managing director of a state-owned housing company & 14.7 .09 \\
\hline \multicolumn{3}{|c|}{ Tenant Associations and Urban Development Consultants } \\
\hline 6 & Deputy managing director of an umbrella tenant organisation & 11.6 .09 \\
\hline 19 & Collaborator of a tenant consulting service & 2.6.09 \\
\hline 21 & Two collaborators of a tenant consulting service & 16.7.09 \\
\hline 14 & Two collaborators of a tenant consulting service & 29.5.09 \\
\hline 27 & District head of a tenant association & 29.6 .09 \\
\hline
\end{tabular}




\begin{tabular}{|r|l|r|}
\hline 29 & Project director of a neighbourhood management team & 23.7 .09 \\
\hline 26 & Project director of neighbourhood management team & 12.5 .09 \\
\hline \multicolumn{2}{|l|}{ Umbrella Organisations for Housing and Urban Development } \\
\hline 9 & Spokesman for an umbrella organisation for housing companies & 1.7 .09 \\
\hline 8 & Deputy managing director of an association for housing and urban development & 22.7 .09 \\
\hline Housing Experts & \\
\hline 1 & Professor for Urban Renewal and Urban Redevelopment, University of Kassel & 9.1 .09 \\
\hline 2 & Managing director of a research institute for housing and urban development & 6.1 .09 \\
\hline 3 & Lecturer for Urban Planning, University of Cottbus & 6.1 .09 \\
\hline 4 & Visiting Professor for Urban Renewal, University of Cottbus & 7.1 .09 \\
\hline 10 & Managing directors of a consulting firm & 2.6 .09 \\
\hline
\end{tabular}




\section{Appendix 2 Interview Guideline (German)}

\section{Interviewleitfaden}

\section{Einleitung}

Vielen Dank, dass Sie sich die Zeit nehmen für dieses Gespräch. Wie ich bereits in meiner Email angekündigt habe, mache ich eine Doktorarbeit zum Thema Wohnungsversorgung in Berlin. Dabei bin ich besonders daran interessiert, die Veränderungen der Wohnungsersorgung in den letzten zehn Jahren besser zu verstehen. Ich hoffe deshalb, dass Sie mir dabei behilflich sein können.

Vier Aspekte sind mir dabei besonders wichtig. Der Prozess der Privatisierung, die Interessen privater Investoren, die Strategien der kommunalen Wohnungsbaugesellschaften und die Rolle des Staates, der Stadt Berlin wie auch der Bezirke. Dies ist jedoch ein Gespräch und soll keine Umfrage sein, deshalb bitte ich Sie, Aspekte, die Sie für wichtig erachten, einzubringen.

Dürfte ich dieses Gespräch aufnehmen? Dies dient vor allem mir, damit ich dem Gespräch besser folgen kann und mir nicht die Hand wund schreibe. Das Gespräch bleibt natürlich anonym.

Vielleicht können Sie, bevor wir mit der ersten Frage beginnen, kurz Ihre Organisation und Ihre Arbeit beschreiben.

Dann lassen Sie uns mit der ersten Einstiegsfrage beginnen:

1. Was erachten Sie als größte Veränderung der Berliner Wohnungsversorgung in den letzten zehn Jahren? Vielleicht können Sie zwei drei Aspekte erläutern.

\section{Privatisierung / Internationalisierung}

Das bringt uns zur Frage der Privatisierungen kommunaler Wohnungsbaugesellschaften, respektive dem kontinuierlichen Rückzug der Stadt aus der Wohnungsversorgung.

\section{Was sind aus Ihrer Sicht die Chancen und Risiken des Verkaufs der kommunalen Woh-} nungs-baugesellschaften an private Investoren?

- Gibt es Unterschiede zwischen internationalen Investoren und lokalen Investoren?

- Mehr Druck auf den Wohnungsmarkt?

- Höhere Mieten?

- Erhöhte Segregation der Bewohner?

- Welche Konsequenzen sehen Sie für Ihre Organisation / für die verbliebenen kommunalen Wohnungsbaugesellschaften?

- Sind gewisse Bezirke/Ortschaften stärker/anders von den Konsequenzen betroffen?

3. Was waren die Umstände für die Privatisierung der Wohnungsbaugesellschaften?

- Weshalb wurde privatisiert?

- Zu welchen Bedingungen? Wie sahen die Verträge aus, gab es da große Unterschiede zwischen den Verkaufsverträgen?

- Wie verpflichtend sind die Verträge?

- Und wie wird die Einhaltung überprüft und gewährleistet?

Wohnungsbaugesellschaften und deren Investoren (Privat und Stadt)

Die drei wichtigsten Akteure in der Wohnungsversorgung sind die Wohnungsbaugesellschaften, die privaten Investoren und die Stadt, einerseits als Investoren andererseits als Regulator. Lassen Sie uns mit den Investoren und den Wohnungsbaugesellschaften beginnen.

\section{Was sind in Ihren Augen die Interessen der Investoren, in Berlin zu investieren?}


- Was sind die Strategien der privaten Investoren? (Umwandlung in Eigentumswohnungen, Weiterverkauf von Portfolios, Erhöhung der Mieten durch Modernisierung, Einsparung der Kosten, Exit-Strategien?)

- Was sind die Investitionskriterien? Weshalb wird in ein spezielles Objekt investiert?

- Wo wird investiert? Gibt es Präferenzen / Kriterien bei der Lage?

- Haben Politikinstrumente wie Steuererleichterungen/Fördermittel Einfluss auf die Investitionsstrategie? (Im Sinne, es wird nur da investiert, wo man Fördergelder erhält)

- Gibt es gewisse staatliche Hinderungsgründe für die Investition?

- Stimmen die staatlichen Interessen mit den privaten überein?

(Frage 4 muss für die kommunalen Wohnungsbaugesellschaften etwas geändert werden: zum Beispiel muss das Thema der Wohnberechtigung angesprochen werden, die zu erfüllenden Quoten.)

5. Wie beeinflusst die Eigentümerstruktur der Wohnungsbaugesellschaft die Strategie der Gesellschaft? (Hier muss je nach Interviewpartner die Frage geändert werden: Wie beeinflusst die Eigentümerstruktur Ihr Machen und Tun?)

- Was ist die Eigentümerstruktur?

- Gab es Strategieänderungen nach der Privatisierung(swelle)?

- Hat sich die Geschäftstätigkeit seither verändert?

\section{Modernisierung}

Die Wohnsiedlung wurde vor einigen Jahren modernisiert. Lassen Sie uns ein wenig über diesen Prozess sprechen.

\section{Weshalb wurde die Siedlung modernisiert?}

- Was wurde genau renoviert/modernisiert? War es eine Luxusrenovierung?

- Wie wurde die Modernisierung finanziert?

- Gab es Subventionen? Wurden die in Anspruch genommen? Zu welchen Bedingungen?

- Gab es Opposition von der Bewohnerschaft? Wie wurde damit umgegangen?

7. Was waren die Konsequenzen der Modernisierung?

- Wie hat sich die Miete entwickelt?

- Wie hat sich die Mieterstruktur entwickelt?

\section{Konsequenzen für die Wohnungsnachfrage}

Wir haben bis anhin vor allem über die Angebotsseite der Wohnungsversorgung gesprochen. Ich möchte Ihnen noch zwei Fragen zur Nachfrageseite stellen.

\section{Was sind die Chancen / Risiken des Privatisierungsprozesses für die Bewohner?}

- Gab es Veränderungen in der Unterhaltung/Bewirtschaftung der Wohnungen?

- Hat sich die Mieterstruktur nach der Privatisierung verändert? Weshalb?

Sie haben zu Beginn angesprochen, dass sich die Belegungs- und Mietregelungen ebenfalls verändert haben.

9. Was sind die Chancen / Risiken der Aufgabe der Belegungsbindungen in einigen Wohnsiedlungen für die Bewohner?

- Ist dieses Projekt von diesen neuen Regelungen betroffen?

\section{Die Rolle des Staates}

Der letzte Aspekt, den ich diskutieren möchte, ist die Rolle des Staates. Wir haben bereits die Rolle des Staates als Wohnungsversorger diskutiert als wir über den Privatisierungs- und Modernisierungsprozess gesprochen haben. Hier möchte ich die Rolle des Staates im Umgang mit den Konsequenzen der Privatisierung wie wir sie oben diskutiert haben, ansprechen - also zum Beispiel eben die erhöhte soziale Segregation. Auf der einen Seite gibt es gewisse politische Instrumente, wie die Festlegung von Sanierungsgebieten, welche die Modernisierung des Wohnungsbestandes fördert und gleichzeitig die Bewohnerschaft vor unbezahlbaren Mieten schützen 
soll. Auf der anderen Seite gibt es informelle Wege, um mit dem erhöhten Druck auf die Mieterstruktur umzugehen.

10. Was für eine Bedeutung haben Ihrer Meinung nach diese politischen oder informellen Instrumente?

- Können diese Instrumente etwas auswirken?

- Was sind die Möglichkeiten / Einschränkungen der Regierung?

11. Verfolgen die Bezirksregierungen eine andere Strategie als die Landesregierung im Umgang mit den Veränderungen in der Wohnungsversorgung?

- Gibt es da gewisse Spannungen zwischen den Regierungsebenen?

- Welche Rolle spielt der Bezirk im Prozess der Wohnungsprivatisierung?

(Frage 11 bei den Bezirken etwas ausführlicher behandeln)

12. Wie geht die Regierung Berlins mit dem Druck um, die Lebensqualität zu erhöhen, global wirtschaftlich mithalten zu können und gleichzeitig mit einem eingeschränkten Budget eine sozialverträgliche Wohnungspolitik zu erbringen? Oder etwas provokative gefragt: Könnte die Regierung überhaupt anders handeln?

\section{Abschluss}

14. Gibt es noch etwas, das Sie gerne ansprechen würden, was bisher nicht diskutiert wurde?

15. Kennen Sie Dokumente zu diesem Projekt, auf die Sie mich hinweisen können? Leute mit denen ich noch sprechen sollte?

Noch einmal vielen Dank für dieses Gespräch. 


\begin{tabular}{|l|l|l|l|}
\hline Organisation & Conference & Date & Location \\
\hline $\begin{array}{l}\text { Leibniz Gemeinschaft } \\
\text { und Technische Univer- } \\
\text { sität }\end{array}$ & $\begin{array}{l}\text { Leeres Land und bunte Stadt? } \\
\text { Räumliche Differenzierung im } \\
\text { Zeichen des demographischen } \\
\text { Wandels }\end{array}$ & $\begin{array}{l}07 .- \\
08.05 .2009\end{array}$ & $\begin{array}{l}\text { Vertretung Nordrhein- } \\
\text { Westfahlen, Berlin }\end{array}$ \\
\hline $\begin{array}{l}\text { Bündnis 90/Die Grünen } \\
\text { Bundestagsfraktion }\end{array}$ & $\begin{array}{l}\text { Gespaltene Städte? Segregation } \\
\text { in der Stadt }\end{array}$ & 15.06 .2009 & $\begin{array}{l}\text { Vertretung Hamburg, } \\
\text { Berlin }\end{array}$ \\
\hline vhw & $\begin{array}{l}\text { Public Value durch Urban Go- } \\
\text { vernance }\end{array}$ & 23.06 .2009 & $\begin{array}{l}\text { Wissenschaftszentrum } \\
\text { Berlin }\end{array}$ \\
\hline $\begin{array}{l}\text { Senatsverwaltung für } \\
\text { Stadtentwicklung Berlin }\end{array}$ & $\begin{array}{l}\text { Stadtumbau in Großsiedlungen } \\
\text { Neutsche Wohnen AG } \\
\text { Nungswirtschaft }\end{array}$ & 08.07 .2009 & $\begin{array}{l}\text { Märkisches Viertel, } \\
\text { Berlin }\end{array}$ \\
\hline
\end{tabular}




\section{Appendix 4 Document List}

\section{Government documents}

\subsection{Parliamentarian Discussions on the Provision of Housing (January 2004 - July 2009)}

(Searched with the following keywords: landeseigene Wohnungsbaugesellschaften, städtische Wohnungsbaugesellschaften, GSW, GEHAG, GEWOBAG, DEGEWO on http://www.parlament-berlin.de:8080/starweb/AHAB/ (last accessed 17.07.2011))

Abgeordnetenhaus Berlin (2004). Durch Kooperationsvertrag ins nächste finanzielle Desaster?, Drucksache 15/11217, 17.02.2004.

Abgeordnetenhaus Berlin (2004). Verkauf der Wohnungsbaugesellschaft GSW, Drucksache 15/11520, 06.05.2004.

Abgeordnetenhaus Berlin (2004). Wie wertvoll ist die GSW?, Drucksache 15/20352, 16.05.2004.

Abgeordnetenhaus Berlin (2004). Wohnungsverkauf durch städtische Wohnungsbaugesellschaften 2001 bis 2003, Drucksache 15/11543, 21.05.2004.

Abgeordnetenhaus Berlin (2004). Dringliche Beschlussempfehlung Nr.5/2004 des Verzeichnisses über Vermögensgeschäfte, Drucksache 15/2968, 17.06.2004.

Abgeordnetenhaus Berlin (2005). Entwicklung nach dem Verkauf der GSW and das Konsortium C./W., Drucksache 15/13002, 05.01.2006.

Abgeordnetenhaus Berlin (2006). Liquiditätsverkäufe der Wohnungsbaugesellschaften ohne Mieterschutz?, Drucksache 15/20656, 30.01.2006.

Abgeordnetenhaus Berlin (2006). Aktuelle Stunde. Öffentlichen Wohnungsbestand des Landes Berlin durch ein tragfähiges Gesamtkonzept dauerhaft sichern. Plenarprotokoll 15/81, 16.02.2006.

Abgeordnetenhaus Berlin (2006). Wohnungsverkauf durch städtische Wohnungsbaugesellschaften 2004 und 2005, Drucksache 15/13161, 15.03.2006.

Abgeordnetenhaus Berlin (2006). Probleme für die GEWOBAG durch Ausstieg aus der Anschlussförderung?, Drucksache 15/13317, 22.03.2006.

Abgeordnetenhaus Berlin (2006). Cerberus - Höllenhund oder Schoßhündchen (Nachfragen zur Kleinen Anfrage 15/13002), Drucksache 15/13198, 12.04.2006.

Abgeordnetenhaus Berlin (2006). GEHAG - Was nützt der Vertrag? Drucksache 15/13605, 14.07.2006.

Abgeordnetenhaus Berlin (2007). Landeseigene Wohnungsbaugesellschaften und Sozialstruktur in der Stadt, Drucksache 16/10293, 15.03.2007.

Abgeordnetenhaus Berlin (2007). Landeseigene Wohnungsbaugesellschaften und Aufgaben für die Stadt, Drucksache 16/10324, 15.03.2007.

Abgeordnetenhaus Berlin (2007). Wirtschaftlichkeit der landeseigenen Wohnungsbaugesellschaften, Drucksache 16/10412, 15.03.2007.

Abgeordnetenhaus Berlin (2007). Vorlage - zur Kenntnisnahme - Gesamtkonzept für die Städtischen Wohnungsbaugesellschaften in Berlin, Drucksache 16/0747, 11.07.2007.

Abgeordnetenhaus Berlin (2007). Wie geht's den MitarbeiterInnen bei privatisierten Wohnungsbaugesellschaften? Drucksache 16/11280, 31.10.2007.

Abgeordnetenhaus Berlin (2008). Die Situation für Mieter in den Beständen der GEHAG, Drucksache 16/11618, 28.02.2008.

Abgeordnetenhaus Berlin (2008). Zur Situation der GSW nach ihrem Verkauf, Drucksache 16/11902, 02.04.2008. 
Abgeordnetenhaus Berlin (2008). Hat der Senat die Mieter und Mitarbeiter der GEHAG vergessen?, Drucksache 16/12179, 07.07.2008.

Abgeordnetenhaus Berlin (2008). Privatisierung aus den Beständen landeseigener Wohnungsbaugesellschaften, Drucksache 16/12356, 12.08.2008.

Abgeordnetenhaus Berlin (2008). Soziale Zusammensetzung der Mieterschaft bei landeseigenen Wohnungsbaugesellschaften, Drucksache 16/12362, 25.08.2008.

Abgeordnetenhaus Berlin (2009). Kommunale Wohnungen, Drucksache 16/13294, 05.05.2009.

\subsection{Press Releases}

Senatsverwaltung für Stadtentwicklung (2003). Kürzung von Fördermitteln im sozialen Wohnungsbau Mieterhöhungen für Großsiedlungen begrenzt, Mitteilung vom 04.11.2003, 16:52 Uhr.

Senatsverwaltung für Finanzen (2004). Senat stimmt Verkauf der GSW zu, Mitteilung vom 25.05.2004, 17:24 Uhr.

Senatsverwaltung für Stadtentwicklung (2005). Belegungsbindung Aufgehoben, Pressebox, 15.12.2005.

Senatsverwaltung für Stadtentwicklung (2006). Belegungsbindung weiter ausgesetzt, Pressebox, 30.15.2006.

Senatsverwaltung für Stadtentwicklung (2007). Gesamtkonzept für städtische Wohnungsbaugesellschaften beschlossen, Mitteilung vom 03.07.2007, 13:45 Uhr.

\subsection{Finance Reports}

Senatsverwaltung für Finanzen (2005-2010). Beteiligungsberichte 2004-2009.

\section{Case Specific Documents}

\subsection{Grüne Stadt, Pankow}

\subsubsection{District Government Documents}

Bezirksverordnetenversammlung Pankow von Berlin (2005). Protokoll - Entwurf, öffentliche Sitzung des Ausschusses für Stadtentwicklung/Bauen und Wohnen, 24.11.2005.

Bezirksverordnetenversammlung Pankow von Berlin (2006). Protokoll - Entwurf, öffentliche Sitzung des Ausschusses für Stadtentwicklung/Bauen und Wohnen, 02.02.2006.

Bezirksverordnetenversammlung Pankow von Berlin (2006). Protokoll - Entwurf, öffentliche Sitzung des Ausschusses für Stadtentwicklung/Bauen und Wohnen, 09.02.2006.

Bezirksverordnetenversammlung Pankow von Berlin (2006). Antrag Betreff: Erlass einer Umstrukturierungssatzung für das Quartier der "Grünen Stadt" und Einleitung eines Sozialplanverfahrens, Drucksache V-1209, 10.02.2006.

\subsubsection{Evaluation Reports}

Mieterberatung Prenzlauer Berg (2007). Auswertung der Sozialdaten der Mieter im Erneuerungsvorhaben "Grüne Stadt”, Zwischenbericht, Berlin, März 2007.

Mieterberatung Prenzlauer Berg (2009). “Grüne Stadt” Bericht zur Sanierung in den Blöcken I und IV und aktueller Stand zur Durchführung des Sozialplanverfahrens, Stand Januar 2009.

\subsubsection{Housing Company Documents}

GSW (2007). Activity Report 2007. 


\subsection{Chamissoplatz, Friedrichshain-Kreuzberg}

\subsubsection{District Government Documents}

Bezirksverordnetenversammlung Friedrichshain-Kreuzberg von Berlin (2004). Antrag Betreff: Einhaltung der 'Grundsätze der Wohnraumprivatisierung in Berlin', Drucksache DS/0963/11, 21.01.04.

\subsubsection{Evaluation Reports}

Senatsverwaltung für Stadtentwicklung (2003). Abschlussbericht zur Entlassung aus dem Sanierungsgebiet: Chamissoplatz.

\subsubsection{Housing Company Documents}

GEWOBAG (2008). Bericht 2008 der GEWOBAG Gemeinnützige WohnungsbauAktiengesellschaft Berlin.

\subsection{Gropiusstadt, Neukölln}

\subsubsection{Housing Company Documents}

Deutsche Wohnen AG (2009). Erläuternder Bericht des Vorstands der Deutsche Wohnen Aktiengesellschaft zu den Angaben nach § 289 Abs. 4 Handelsgesetzbuch (Lagebericht) und § 315 Abs. 4 Handelsgesetzbuch (Konzernlagebericht) zum 31. Dezember 2008.

DEGEWO (2008). Geschäftsbericht 2008.

DEGEWO (2009). Stadtleben. Das Mietermagazin, Ausgabe 2/2009.

DEGEWO (2009). Die Gropiusstadt - Raum für die ganze Familie. Gut leben. Günstig wohnen. Alles in der Nähe, Mai 2009.

DEGEWO (2009). Stadtsicht. Newsletter der degewo, Mai 2009.

DEGEWO (2009). Stadt gestalten. 20 Jahre Mauerfall.

\subsection{High-Deck-Siedlung, Neukölln}

\subsubsection{Letting Ad}

Du Chesne Immobilien GmbH (2009). Auch mit schlechter Schufa! $250 €$ Gutschein +3 Monate mietfrei + provisionsfrei, http://duchesne-immobilien.de/index3.htm [accessed on 30.06.09]

\subsubsection{Housing Company Documents}

Stadt und Land (2007). Geschäftsbericht 2007. 
Appendix 5 Networks of the Data Analysis

Appendix 5.1: Reorganisation of Housing Provision Appendix 5.2: Regulation

Appendix 5.3: Institutional Investors

Appendix 5.4: State-owned Housing Companies 
Appendix 5.1: Reorganisation of Housing Provision

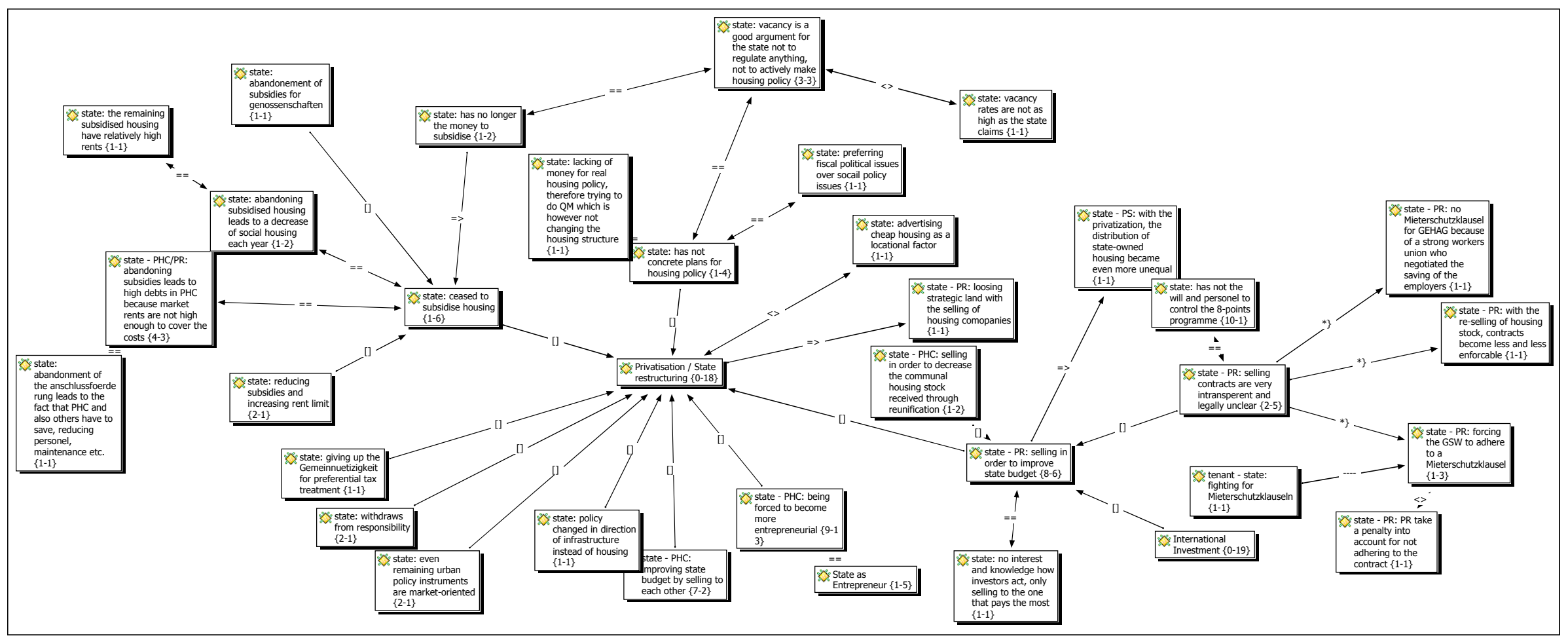




\section{Appendix 5.2: Regulation}

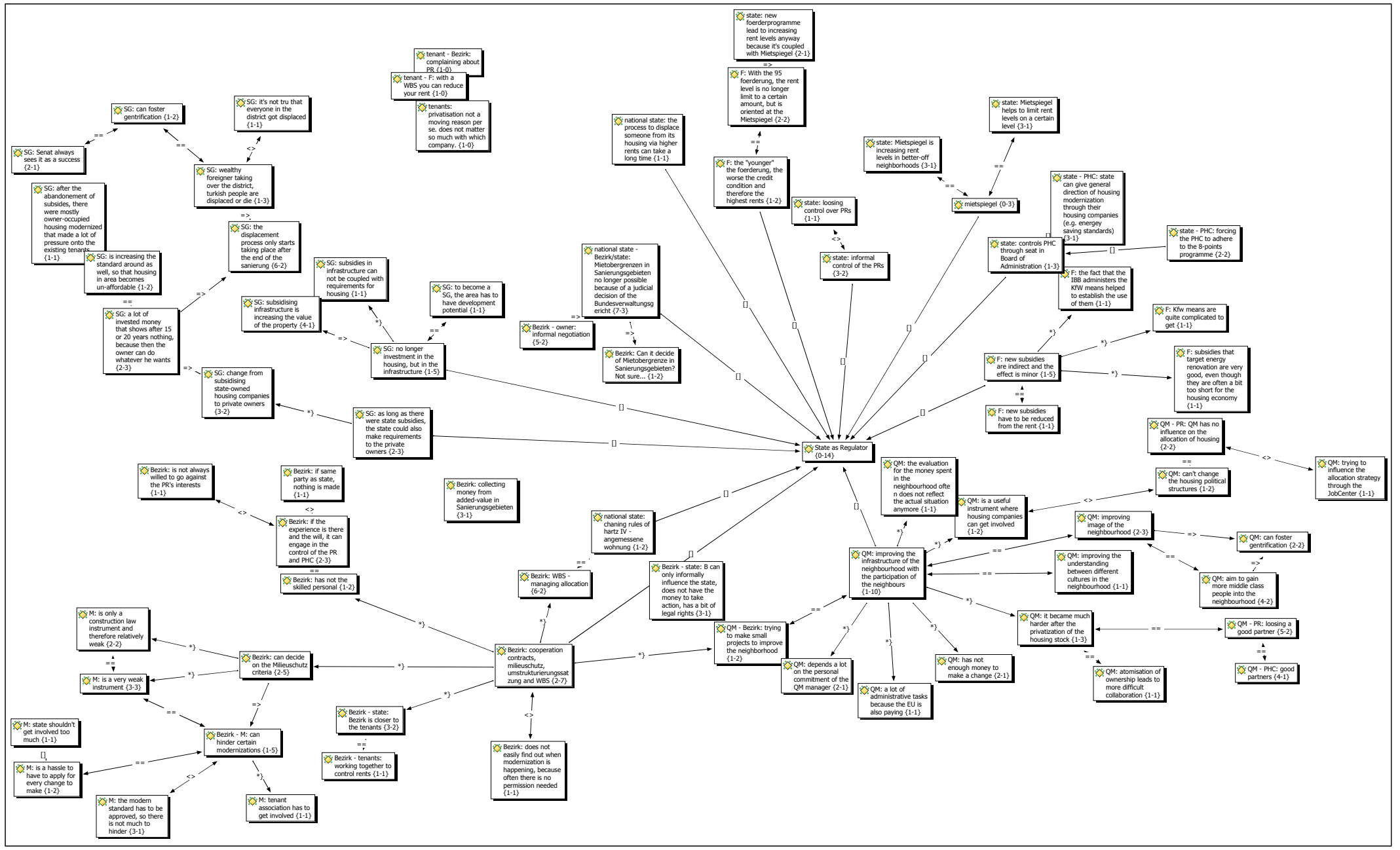




\section{Appendix 5.3: Institutional Investors}

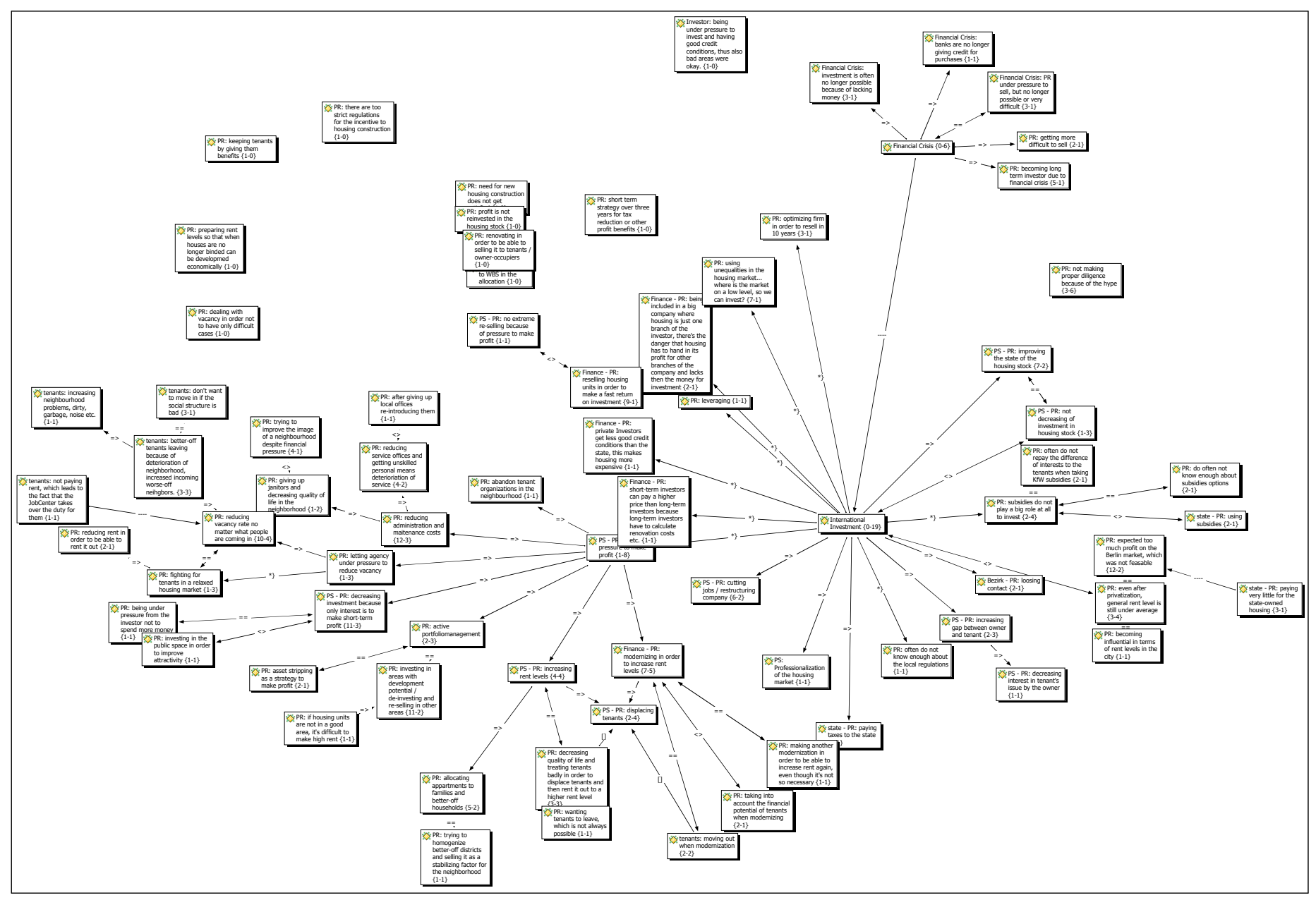




\section{Appendix 5.4: State-owned Housing Companies}

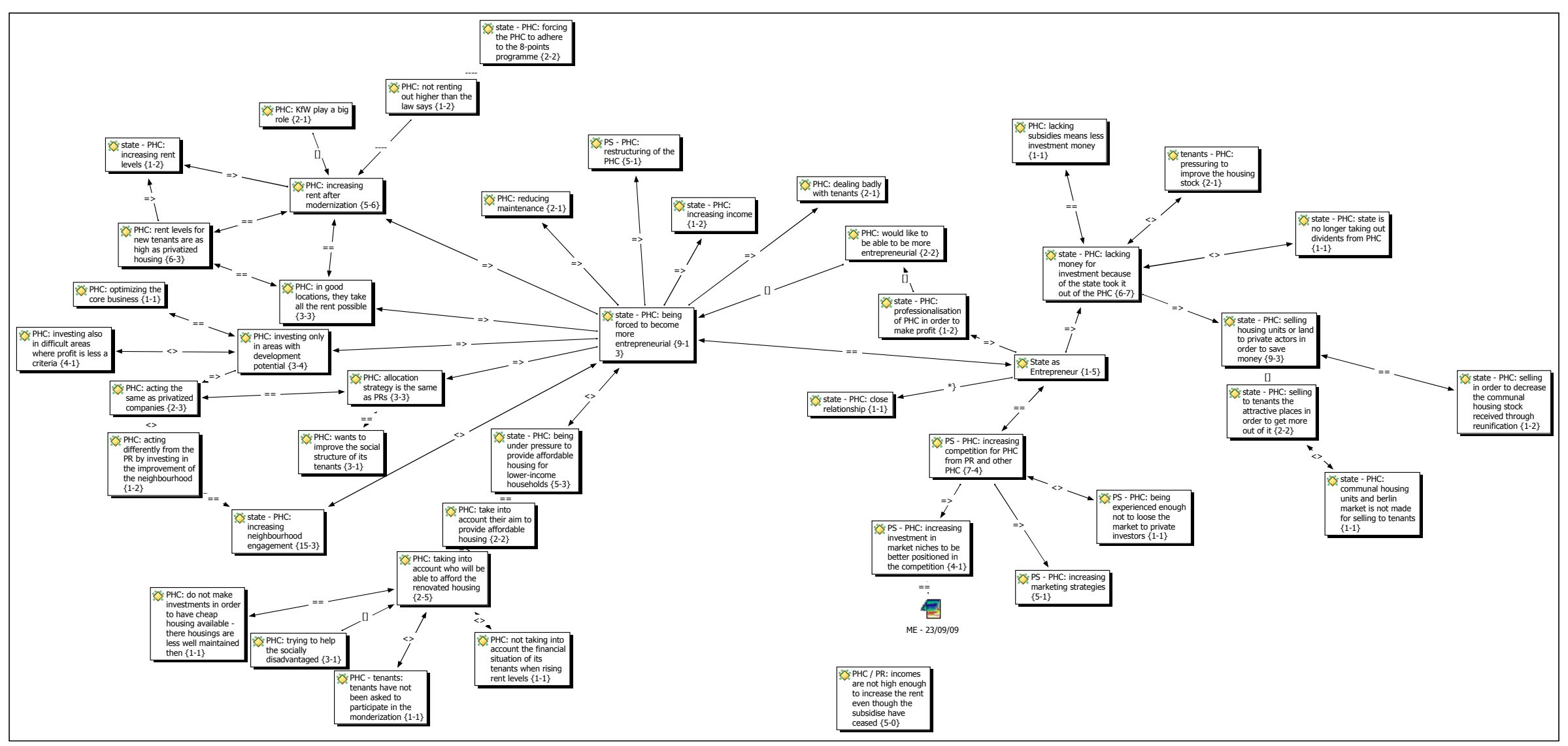




\section{Bibliography}

Aalbers, M. B. (2004). "Promoting Home Ownership in a Social-rented City: Policies, Practices and Pitfalls." Housing Studies 19(3): 483-495.

Aalbers, M. B. and Holm, A. (2008). "Privatising Social Housing in Europe: The Cases of Amsterdam and Berlin." Urban Trends in Berlin and Amsterdam. Heft 110. K. Adelhof, B. Glock, J. Lossau and M. Schulz. Berlin, Geographisches Institut, HU Berlin: 12-23.

Abgeordnetenhaus Berlin (2006). "Aktuelle Stunde. Öffentlichen Wohnungsbestand des Landes Berlin durch ein tragfähiges Gesamtkonzept dauerhaft sichern." Berlin, Parlament Berlin. Plenarprotokoll 15/81 vom 16. Februar 2006.

Aglietta, M. (1976). Régulation et crises du capitalisme. Paris, Calmann-Lévy.

Aglietta, M. (1978). "Phases of US Capitalist Expansion." New Left Review I(110): 17-28.

Allen, J. (1987). "Review Essay on Sayer, A. Method in Social Science: A Realist Approach." Antipode 19(2): 231-240.

Amin, A. and Robins, K. (1990). "The Re-emergence of Regional Economies? The Mythical Geography of Flexible Accumulation." Environment and Planning D: Society and Space 8(1): 7-34.

Amt für Statistik Berlin-Brandenburg. (2009a). "Arbeitsmarkt in Zahlen Jahreszahlen-, Bundesagentur für Arbeit, Zeitreihen, Stand Dezember 2007." Retrieved 16.03.2011, from http://www.statistik-berlin-brandenburg.de/.

Amt für Statistik Berlin-Brandenburg. (2009b). "Bevölkerungsstand. Zeitreihen." Retrieved 5.4.2010, from www.statistik-berlin-brandenburg.de.

Amt für Statistik Berlin-Brandenburg. (2009c). "Volkswirtschaftliche Gesamtrechnungen 2009." Retrieved 16.03.2011, from http://www.statistikberlin-brandenburg.de/.

Amt für Statistik Berlin-Brandenburg (2010). "1990-2010 Berlin und Brandenburg. Bevölkerungsentwicklung." Zeitschrift für amtliche Statistik Berlin Brandenburg. Berlin. 3/2010.

Anonymous Author. (2010). "Brennende-Autos.de." Retrieved 11.10.2010, from www.brennende-autos.de.

Bader, I. and Scharenberg, A. (2010). "The Sound of Berlin: Subculture and the Global Music Industry." International Journal of Urban and Regional Research 34(1): 76-91. 
Baeten, G. (2000). "From Community Planning to Partnership Planning. Urban Regeneration and Shifting Power Geometries on the South Bank, London." GeoJournal 51(4): 293-300.

Ball, M. (1983). Housing Policy and Economic Power: The Political Economy of Owner Occupation London, Methuen.

Ball, M. (1986). "Housing Analysis: Time For a Theoretical Refocus?" Housing Studies 1(3): 147-166.

Ball, M. (1990). Under One Roof : Retail Banking and the International Mortgage Finance Revolution. London, Harvester Wheatsheaf.

Ball, M. (2007). "Large-scale Investor Opportunities in Residential Property: An Overview." IPF Research Programme 2006-2009.

Ball, M. and Harloe, M. (1992). "Rhetorical Barriers to Understanding Housing Provision: What the 'Provision Thesis' Is and Is Not." Housing Studies 7(1): 3-15.

Ball, M., et al. (1988). Housing and Social Change in Europe and the USA. London, Routledge.

Beauregard, R. A. (1993). Voices of Decline: The Postwar Fate of American Cities. New York, Blackwell.

Berliner Mieterverein (2009). "Zahl ohne Wert? Berlins Leerstandsstatistik auf dem Prüfstand." MieterMagazin (5): 14-18.

Bernet, C. (2004). "The 'Hobrecht Plan' (1862) and Berlin's Urban Structure." Urban History 31(3): 400-419.

Bernhardt, C. (1999). "Aufstieg und Krise der öffentlichen Wohnungsbauförderung in Berlin." Wohnen in Berlin. 100 Jahre Wohnungsbau in Berlin.

Arbeitsgemeinschaft der Berliner Wohnungsbaugesellschaften und der Investitionsbank Berlin. Berlin, Edition StadtBauKunst: 45-87.

Bernt, M. and Holm, A. (2005). "Exploring the Substance and Style of Gentrification: Berlin's 'Prenzlberg'." Gentrification in a Global Context. R. Atkinson and G. Bridge. Oxford, Routledge: 106-120.

Bernt, M. and Holm, A. (2009). "Is It, or Is Not? The Conceptualisation of Gentrification and Displacement and Its Political Implications in the Case of Berlin-Prenzlauer Berg." City 13(2): 312-324.

Berry, M. (2000). "Investment in Rental Housing in Australia: Small Landlords and Institutional Investors." Housing Studies 15(5): 661-681.

Berry, M. and Hall, J. (2005). "Institutional Investment in Rental Housing in Australia: A Policy Framework and Two Models." Urban Studies 42(1): 91-111.

Bertramsen, R. B., et al. (1991). State, Economy and Society. London, Unwin Hyman. 
Besecke, A. and Enbergs, C. (2008). "Professionelle Wohnungsunternehmen und soziales Engagement. Duett oder Dissonanz — Das Beispiel Berlin." Graue Reihe des Instituts für Stadt- und Regionalplanung Technische Universität Berlin Heft 11.

Bhaskar, R. (1979). The Possibility of Naturalism. New York, Harvester Wheatsheaf.

Blaikie, N. W. H. (1991). "A Critique of the Use of Triangulation in Social Research." Quality \& Quantity 25(2): 115-136.

Blöcker, U. and Hieber, U., Eds. (2003). Die Europäische Union und die Städtebau-, Wohnungsbau- und Baupolitik in Deutschland. Positionspapier des Arbeitskreises Wohnungspolitik der Friedrich-Ebert-Stiftung. Bonn, Friedrich Ebert Stiftung.

Bodenschatz, H. (1999). "Wohnungsbaukonzeptionen in der geteilten Stadt." Wohnen in Berlin. 100 Jahre Wohnungsbau in Berlin. Arbeitsgemeinschaft der Berliner Wohnungsbaugesellschaften und der Investitionsbank Berlin. Berlin, Edition StadtBauKunst: 222-238.

Boyer, R. (1986). La théorie de la régulation: une analyse critique. Paris, Editions La Découverte.

Bremer, A., et al. (2007). Kreuzberg Chamissoplatz. Geschichte eines Berliner Sanierungsgebiet. Berlin, Propolis Verlag.

Brenner, N. (1998). "Global Cities, Glocal States: Global City Formation and the State Territorial Restructuring in Contemporary Europe." Review of International Political Economy 5(1): 1-37.

Brenner, N. (1999). "Globalisation as Reterritorialisation: The Re-scaling of Urban Governance in the European Union." Urban Studies 36(3): 431-451.

Brenner, N. (2002). "Review Essay: Berlin's Transformations: Postmodern, Postfordist... or Neoliberal?" International Journal of Urban and Regional Research 26(3): 635-642.

Brenner, N. (2004a). New State Spaces. Urban Governance and the Rescaling of Statehood. Oxford, Oxford University Press.

Brenner, N. (2004b). "Urban Governance and the Production of New State Spaces in Western Europe." Review of International Political Economy 11(3): 447-488.

Brenner, N. (2009). "A Thousand Leaves: Notes on the Geographies of Uneven Spatial Development." Leviathan Undone? Towards a Political Economy of Scale. R. Keil and R. Mahon. Vancouver, UBC Press: 27-49.

Brenner, N. and Theodore, N. (2002). "Cities and the Geographies of "Actually Existing Neoliberalism"." Antipode 34(3): 349-379.

Brenner, R. and Glick, M. (1991). "Regulation Approach: Theory and History." New Left Review I(188): 45-119. 
Brueggeman, W. B. and Fisher, J. D. (2008). Real Estate Finance and Investments. Maidenhead, McGraw Hill Education.

Bundesministerium der Justiz (1993). "Gesetz über die Altschuldenhilfen für Kommunale Wohnungsunternehmen, Wohnungsgenossenschaften und private Vermieter in dem in Artikel 3 des Einigungsvertrages genannten Gebiet (Altschuldenhilfe-Gesetz)." Bundesministerium der Justiz.

Bundesministerium der Justiz (2009). "Bürgerliches Gesetzbuch." Bundesministerium der Justiz.

Burkhardt, L. (1999). "Berliner Wohnungswirtschaft gestern, heute und morgen." Wohnen in Berlin. 100 Jahre Wohnungsbau in Berlin. Arbeitsgemeinschaft der Berliner Wohnungsbaugesellschaften und der Investitionsbank Berlin. Berlin, Edition StadtBauKunst: 26-29.

Campbell, S. (1999). "Capital Reconstruction and Capital Accumulation in Berlin: A Reply to Peter Marcuse." International Journal of Urban and Regional Research 23(1): 173-179.

Castells, M. (2000). Information Age: Economy, Society and Culture. Volume 1. The Rise of the Network Society. Oxford, Blackwell.

Chorianopoulos, I. (2008). "Institutional Responses to EU Challenges: Attempting to Articulate a Local Regulatory Scale in Greece." International Journal of Urban and Regional Research 32(2): 324-343.

Cochrane, A. and Jonas, A. (1999). "Reimagining Berlin: World City, National Capital or Ordinary Place?" European Urban and Regional Studies 6(2): 145-164.

Cochrane, A. and Passmore, A. (2001). "Building a National Capital in an Age of Globalization: The Case of Berlin." Area 33(4): 341-352.

Coleman, R., et al. (2005). "Capital, Crime Control and Statecraft in the Entrepreneurial City." Urban Studies 42(13): 2511-2530.

Colomb, C. (2007). "Requiem for a Lost Palast. 'Revanchist Urban Planning' and 'Burdened Landscapes' of the German Democratic Republic in the New Berlin." Planning Perspectives 22(3): 283-323.

Davidson, M. (2008). "Spoiled Mixture: Where Does State-led 'Positive' Gentrification End?" Urban Studies 45(12): 2385-2405.

De Frantz, M. (2006). "Localizing Multi-Level Space in Urban Cultural Politics: The Reconstruction of the Museumquartier Wien and the Schlossplatz in Berlin." Rethinking European Spatial Policy as a Hologram. Actions, Institutions, Discourses. L. Doria, V. Fedeli and C. Tedesco. Aldershot, Ashgate: 45-57.

Degewo (2008). "Die wahren Werte. Wie soziale Verantwortung sich auszahlt: Die Stadtrendite der degewo." Berlin, Degewo. 
Degewo. (2011). "Engagement für die Stadt." Retrieved 14.03.2011, from http://www.degewo.de/content/de/Unternehmen/4-4-Engagement-fuer-dieStadt.html.

Denzin, N. K. (1970). The Research Act in Sociology: A Theoretical Introduction to Sociological Methods. London, Butterworths.

Deutscher Bundestag (2007). "Bund will 2007 knapp 16.000 Wohnungen verkaufen." Parlamentskorrespondenz. 11.07.2007.

Dicken, P. (2003). Global Shift. Reshaping the Global Economic Map in the 21st Century. London, Sage.

Dicken, P. (2007). Global Shift. Mapping the Changing Contours of the World Economy. 5th Edition. London, Sage.

DISP (2004). "Berlin - 15 Jahre ohne Mauer. Berlin - 15 Years on. Special Edition." DISP 156(1).

Doling, J. (1999). "De-commodification and Welfare: Evaluating Housing Systems." Housing, Theory and Society 16(4): 156-164.

Downs, A. (2009). Real Estate and the Financial Crisis. How Turmoil in the Capital Markets Is Restructuring Real Estate Finance. Washington, D.C., Urban Land Institute.

Droste, C. and Knorr-Siedow, T. (2007). "Social Housing in Germany." Social Housing in Europe. C. Whitehead and K. Scanlon. London, London School of Economics and Political Science: 90-104.

Du Chesne Immobilien GmbH. (2009). "Auch mit schlechter Schufa $200 €$ Gutschein + 3 Monate mietfrei + provisionsfrei." Retrieved 17.12.2009, from http://www.duchesne-immobilien.de/index3.htm.

Duncan, S. and Goodwin, M. (1988). The Local State and Uneven Development. Oxford, Blackwell.

Duncan, S. S. (1981). "Housing Policy, the Methodology of Levels, and Urban Research: The Case of Castells." International Journal of Urban and Regional Research 5(2): 231-254.

Duvigneau, H. J. (2001). "Die neue Rolle der Wohnungsunternehmen." Programmheft zum Kongress wohn:wandel 5/2001.

Edgar, B. and Taylor, J. (2000). "Housing." Urban Regeneration. A Handbook. P. Roberts and H. Sykes. London, Sage: 153-173.

Eekhoff, J. and Mackscheidt, K. (2006). "Auswirkungen von Hartz IV auf die Mobilität und Wohnungsversorgung der Mieter." Wirtschaftsdienst 86(4): 236-243.

Egner, B., et al. (2004). Wohnungspolitik in Deutschland. Positionen. Akteure. Instrumente. Darmstadt, Schader-Stiftung. 
Eick, V. (1998). "Neue Sicherheitsstrukturen im "neuen" Berlin. Warehousing öffentlichen Raums und staatlicher Gewalt." Prokla 28(1): 95-118.

Emms, P. (1990). Social Housing. A European Dilemma? Bristol, School for Advanced Urban Studies.

Endres, A. (2010). "Die Zukunft gehört Berlin." ZEIT Online. Hamburg, ZEIT Online. 27.10.2010.

Falzon, R., et al. (2003). "Private Equity Investment Opportunities in Real Estate." The Journal of Private Equity (Spring 2003): 68-78.

Fine, B. and Leopold, E. (1993). The World of Consumption. London, Routledge.

Florida, R. (2003). "Cities and the Creative Class." City \& Community 2(1): 3-19.

Fosler, S. R. (1992). "State Economic Policy: The Emerging Paradigm." Economic Development Quarterly 6(1): 3-13.

Frey, G. (2003). "Money Talk. Lassen Sie uns über Geld reden... Klaus Wowereit, Regierender Bürgermeister von Berlin." Focus. München, Focus Magazin Verlag. Nr. 46, 16. November: 90.

Friedmann, J. (1986). "The World City Hypothesis." Development and Change 17(1): 69-84.

Gaskell, G. (2000). "Individual and Group Interviewing." Qualitative Researching with Text, Image and Sound. G. Gaskell and M. W. Bauer. London, Sage: 38-56.

Geschäftsstelle des Gutachterausschusses für Grundstückswerte in Berlin (2009). "Allgemeine Angaben und Rahmendaten zum Bericht über den Berliner Grundstücksmarkt 2008 / 2009, der Grundstücksmarkt im Überblick." Senatsverwaltung für Stadtentwicklung. Berlin.

Geyer, M. (1999). "Die Gropiusstadt. Wohnzufriedenheit und Umzugsabsichten in einer Großsiedlung." Unveröffentlichte Diplomarbeit, Geographisches Institut der Freien Universtität Berlin.

Ghékiere, L. (1992). "Les politiques du logement dans l'Europe de demain." Union Nationale des Fédérations d'Organismes HLM. Paris, La Documentation Française.

Giddens, A. (1979). Central Problems in Social Theory. Action, Structure and Contradiction in Social Analysis. Berkeley, Unviersity of California Press.

Giddens, A. (1984). The Constitution of Society. Cambridge, Polity.

Glaser, B. G. and Strauss, A. L. (2009). The Discovery of Grounded Theory: Strategies for Qualitative Research. Piscataway, New Jersey, Transaction Publishers.

Golland, A. (1998). Systems of Housing Supply and Housing Production in Europe. Aldershot, Ashagte. 
Gómez, M. V. (1998). "Reflective Images: The Case of Urban Regeneration in Glasgow and Bilbao." International Journal of Urban and Regional Research 22(1): 106-121.

Goodwin, M. (2001). "Regulation as Process: Regulation Theory and Comparative Urban and Regional Research." Journal of Housing and the Built Environment 16(1): 71-87.

Goodwin, M., et al. (1993). "Regulation Theory, the Local State, and the Transition of Urban Politics." Environment and Planning D: Society and Space 11(1): 67-88.

Goodwin, M. and Painter, J. (1996). "Local Governance, the Crises of Fordism and the Changing Geographies of Regulation." Transactions of the Institute of British Geographers, New Series 21(4): 635-648.

Gordon, I. (1999). "Internationalisation and Urban Competition." Urban Studies 36(56): 1001-1016.

GSW (2007). "Grüne Stadt, Berlin-Prenzlauer Berg." Exposé. Berlin, Real Estate Stuttgart im Auftrag der GSW.

Hake, S. (2008). Topographies of Class. Modern Architecture and Mass Society in Weimar Berlin. Ann Arbor, University of Michigan Press.

Hall, P. (2002). Cities of Tomorrow: An Intellectual History of Urban Planning and Design in the Twentieth Century. Oxford, Blackwell.

Hall, T. and Hubbard, P., Eds. (1998). The Entrepreneurial City. Geographies of Politics, Regime and Representation. Chichester, John Wiley \& Sons Ltd.

Hallenberg, B. (2008). "Die Transformation der Wohnangebotslandschaft - Folgen für Mietbelastung und Sozialstrukturen. Ergebnisse des Projektes für entspannte Wohnungsmärkte." Berlin, Vhw - Bundesverband für Wohnen und Stadtentwicklung e.V.

Hamnett, C. (2000). "Gentrification, Postindustrialism, and Industrial and Occupational Restructuring in Global Cities." A Companion to the City. G. Bridge and S. Watson. Oxford, Blackwell: 331-341.

Hanauske, D. (1995). "Bauen, bauen, bauen...!" Die Wohnungspolitik in Berlin (West) 1945-1961. Berlin, Akademie Verlag.

Hanauske, D. (1999). "Der Wiederaufbau in West-Berlin bis zur Umstellung der Wohnungsbauförderung." Wohnen in Berlin. 100 Jahre Wohnungsbau in Berlin. Arbeitsgemeinschaft der Berliner Wohnungsbaugesellschaften und der Investitionsbank Berlin. Berlin, Edition StadtBauKunst: 88-115.

Hannemann, C. (1996). Die Platte: industrialisierter Wohnungsbau in der DDR. Braunschweig, Vieweg.

Harloe, M. (1995). The People's Home? Social Rented Housing in Europe and America. Oxford, Blackwell. 
Harris, A. (2008). "From London to Mumbai and Back Again: Gentrification and Public Policy in Comparative Perspective." Urban Studies 45(12): 2407-2428.

Harrison, B. and Bluestone, B. (1990). "Wage Polarisation in the US and the 'Flexibility' Debate." Cambridge Journal of Economics 14(3): 351-373.

Harvey, D. (1982). The Limits to Capital. London, Verso.

Harvey, D. (1985). The Urbanization of Capital. Oxford, The John Hopkins University Press.

Harvey, D. (1989). "From Managerialism to Entrepreneurialism: The Transformation in Urban Governance in Late Capitalism." Geographiska Annaler 71(B): 3-17.

Harvey, D. (2006). Spaces of Global Capitalism: Towards a Theory of Uneven Geographical Development. London, Verso.

Haspel, J. and Jaeggi, A., Eds. (2007). Housing Estates in the Berlin Modern Style. Berlin, Deutscher Kunstverlag.

Häußermann, H. (1999). "Economic and Political Power in the New Berlin: A Response to Peter Marcuse." International Journal of Urban and Regional Research 23(1): 180-184.

Häußermann, H., et al. (2002). Stadterneurung in der Berliner Republik. Modernisierung in Berlin-Prenzlauer Berg. Opladen, Leske + Budrich.

Häußermann, H. and Kapphan, A. (2002). Berlin: Von der geteilten zur gespaltenen Stadt? Sozialräumlicher Wandel seit 1990. Opladen, Leske + Budrich.

Heeg, S. (1998). "'Vom Ende der Stadt als staatlicher Veranstaltung". Reformulierung städtischer Politikformen am Beispiel Berlin." Prokla 28(1): 5-23.

Heinz, W. (1991). "The Role of Local Authorities in Meeting Housing Need." Low Income Housing in Britain and Germany. A. Norton and K. Novy. London, AngloGerman Foundation: 83-107.

Held, D. and McGrew, A. (2002). Globalization/Anti-Globalization. Cambridge, Polity.

Held, D. and McGrew, A., Eds. (2003). The Gobal Transformations Reader. An Introduction to the Globalization Debate. Cambridge, Polity.

Herring, R. J. and Litan, R. E. (1995). Financial Regulation in the Global Economy. Washington, D.C., The Brookings Institution.

Hirschman, A. O. (1958/1988). The Strategy of Economic Development. London, Westview Press.

Hirst, P. and Thompson, G. (2003). "The Limits to Economic Globalization." The Global Transformations Reader. D. Held and A. McGrew. Cambridge, Polity: 335-348. 
Holm, A. (2005). "Die Bindung an die Kostenmiete wird in Berlin zum Problem." MieterEcho. Berlin, Berliner Mieter Gemeinschaft e.V. 312.

Holm, A. (2006). Die Restrukturierung des Raumes. Stadterneuerung der 90er Jahre in Ostberlin: Interessen und Machtverhältnisse. Bielefeld, transcript Verlag.

Holm, A. (2010). "Privare heisst rauben - Zur Ökonomie von Wohnungsprivatisierungen." Z - Zeitschrift marxistische Erneurung 21(83): 46-59.

Hubbard, P. and Hall, T. (1996). "The Entrepreneurial City: New Urban Politics, New Urban Geographies?" Progress in Human Geography 20(2): 153-174.

Hughes, G. (1999). "Urban Revitalization: The Use of Festive Time Strategies." Leisure Studies 18(2): 119-135.

Investitionsbank Berlin (2009). "IBB Wohnungsmarktbericht 2008."

Investitionsbank Berlin (2010). "IBB Wohnungsmarktbericht 2009." Berlin, Investitionsbank.

Investitionsbank Berlin. (2011). "Förderangebote: Wohnen und Modernisieren mit der IBB." Retrieved 26.03.2011, from http://www.ibb.de/desktopdefault.aspx/tabid$\underline{120 / .}$.

Jessop, B. (1990a). "Regulation Theories in Retrospect and Prospect." Economy and Society 19(2): 153-216.

Jessop, B. (1990b). State Theory: Putting the Capitalist State in Its Place. Oxford, Blackwell.

Jessop, B. (1994a). "Post-Fordism and the State." Post-Fordism: A Reader. A. Amin. Oxford, Blackwell: 251-279.

Jessop, B. (1994b). "The Transition to Post-Fordism and the Schumpeterian Workfare State." Towards a Post-Fordist Welfare State. B. Burrows and B. Loader. London, Routledge: 13-37.

Jessop, B. (1995a). "The Future of the Nation State: Erosion or Reorganisation?" Lancaster Regionalism Group Working Papers. Lancaster, University of Lancaster.

Jessop, B. (1995b). "The Regulation Approach, Governance and Post-Fordism: Alternative Perspectives on Economic and Political Change?" Economy and Society 24(3): 307-333.

Jessop, B. (1997a). "A Neo-Gramscian Approach to the Regulation of Urban Regimes: Accumulation Strategies, Hegemonic Projects, and Governance." Reconstructing Urban Regime Theory. M. Lauria. London, Sage: 51-73.

Jessop, B. (1997b). "The Entrepreneurial City: Re-imaging Localities, Redesigning Economic Governance or Restructuring Capital." Transforming Cities: Contested Governance and New Spatial Divisions. N. Jewson and M. Susanne. London, Routledge: 28-41. 
Jessop, B. (1997c). "Twenty Years of the (Parisian) Regulation Approach: The Paradox of Success and Failure at Home and Abroad." New Political Economy 2(3): 503-526.

Jessop, B. (2001). "Institutional Re(turns) and the Strategic-Relational Approach." Environment and Planning A 33(7): 1213-1235.

Jessop, B. (2002). "Liberalism, Neoliberalism and Urban Governance: A StateTheoretical Perspective." Antipode 34(3): 452-472.

Jessop, B. (2005). "Critical Realism and the Strategic-Relational Approach." New Formations (56): 40-53.

Jessop, B. (2007). State Power. A Strategic-Relational Approach. Cambridge, Polity.

Jessop, B., et al. (2008). "Theorizing Sociospatial Relations." Environment and Planning D: Society and Space 26(3): 389-401.

Jones, M. (1997). "Spatial Selectivity of the State? The Regulationist Enigma and Local Struggles over Economic Governance." Environment and Planning A 29(5): 831-864

Jones, M. and MacLeod, G. (1999). "Towards a Regional Renaissance? Reconfiguring and Rescaling England's Economic Governance." Transactions of the Institute of British Geographers, New Series 24(3): 295-313.

Katz, C. (2001). "Hiding the Target: Social Reproduction in the Privatized Urban Environment." Postmodern Geography. Theory and Praxis. C. Minca. Oxford, Blackwell: 93-110.

Kelle, U., Ed. (1995). Computer-aided Qualitative Data Analysis. London, Sage.

Kemeny, J. and Lowe, S. (1998). "Schools of Comparative Housing Research: From Convergence to Divergence." Housing Studies 13(2): 161-176.

Kemper, F.-J. (1998). "Residential Segregation and Housing in Berlin: Changes since Unification." GeoJournal 46(1): 17-28.

Kleinman, M. (1996). Housing, Welfare and the State in Europe. A Comparative Analysis of Britain, France and Germany. Glos, Edward Elgar Publishing Limited.

Knorr-Siedow, T. and Droste, C. (2005). "Large Housing Estates in Berlin, Germany. Opinions of Residents on Recent Developments." RESTATE. Restructuring Largescale Housing Estates in European Cities: Good Practices and New Visions for Sustainable Neighbourhoods and Cities. Utrecht, Urban and Regional Research Centre.

Knox, P. L. and Taylor, P. J. (1995). World Cities in a World-System. Cambridge, University Press.

Kofner, S. (2004). Wohnungsmarkt und Wohnungswirtschaft. München, Oldenbourg Wissenschaftsverlag. 
Kohlenberg, K. (2010). "Die Krieger von Kreuzberg." DIE ZEIT. Hamburg, Zeitverlag Gerd Bucerious GmbH \& Co. KG. Nr. 9, 25. Februar: 15-17.

Kolland, D., Ed. (2002). Der lange Weg zur Stadt. Die Gropiusstadt im Umbruch. Berlin, Kramer Verlag.

Krätke, S. (2001). "Berlin: Towards a Global City?" Urban Studies 38(10): 17771799.

Krätke, S. (2004). "Economic Restructuring and the Making of a Financial Crisis." DISP 156(1): 58-63.

Krätke, S. and Borst, R. (2000). Berlin. Metropole zwischen Boom und Krise. Opladen, Leske + Budrich.

Kuhn, G. (1999). "Die Wohnungsbaupolitik in West-Berlin vom qualitativen Ausbau zur Marktregulierung." Wohnen in Berlin. 100 Jahre Wohnungsbau in Berlin. Arbeitsgemeinschaft der Berliner Wohnungsbaugesellschaften und der Investitionsbank Berlin. Berlin, Edition StadtBauKunst: 116-140.

Kvale, S. (1996). Interviews. An Introduction to Qualitative Research Interviewing. London, Sage.

LaSalle Investment Management (2009). Real Estate in a Global Market. Presentation to LSE Master students in Real Estate Economics and Finance by Robin Goodchild, International Director: Head of Research \& Strategy, LaSalle Investment Management, November 2009, London.

Latham, A. (2006a). "Anglophone Urban Studies and the European City: Some Comments on Interpreting Berlin." European Urban and Regional Studies 13(1): 88-92.

Latham, A. (2006b). "Berlin and Everywhere Else: A Reply to Allan Cochrane." European Urban and Regional Studies 13(4): 377-379.

Lawson, J. M. (2001). "Comparing the Causal Mechanisms Underlying Housing Networks over Time and Space." Journal of Housing and the Built Environment 16(1): 29-52.

Lawson, J. M. (2006). Critical Realism and Housing Research. Oxon, Routledge.

Lawson, J. M. (2010). "Path Dependency and Emergent Relations: Explaining the Different Role of Limited Profit Housing in the Dynamic Urban Regimes of Vienna and Zurich." Housing, Theory and Society 27(3): 204-220.

Lawson, J. M., et al. (2009). "Comparative Housing Research in the New Millenium: Methodological and Theoretical Contributions from the First Decade." 4th Australasian Housing Researchers Conference. Sydney.

Layder, D. (1993). New Strategies in Social Research. Cambridge, Polity. 
Lee, S. Y., et al. (2004). "Creativity and Entrepreneurship: A Regional Analysis of New Firm Formation." Regional Studies 38(8): 879-891.

Lees, L. (2003). "Policy (Re)turns: Gentrification Research and Urban Policy - Urban Policy and Gentrification Research." Environment and Planning A 35(4): 571-574.

Lees, L. (2008). "Gentrification and Social Mixing: Towards an Inclusive Urban Renaissance?" Urban Studies 45(12): 2449-2470.

Lees, L., et al. (2008). Gentrification. New York, Routledge.

Leitner, H. (1990). "Cities in Pursuit of Economic Growth. The Local State as Entrepreneur." Political Geography Quarterly 9(2): 146-170.

Leitner, H. and Sheppard, E. (1998). "Economic Uncertainty, Inter-Urban Competition and the Efficacy of Entrepreneurialism." The Entrepreneurial City. Geographies of Politics, Regime and Representation. T. Hall and P. Hubbard. Chichester, John Wiley \& Sons Ltd: 285-307.

Lenhart, K. (1998). "'Bubble-politics" in Berlin. Das Beispiel Koordinierungsausschuß für innerstädtische Investitionen: eine "black box" als Macht- und Entscheidungszentrale." Prokla 28(1): 41-66.

Lenhart, K. (2001). Berliner Metropoly. Opladen, Leske \& Budrich.

Lever, W. F. and Turok, I. (1999). "Competitive Cities: Introduction to the Review." Urban Studies 36(5): 791-793.

Levine, M. A. (2004). "Government Policy, the Local State, and Gentrification: The Case of Prenzlauer Berg (Berlin), Germany." Journal of Urban Affairs 26(1): 89108.

Ley, D. (1996). The New Middle Class and the Remaking of the Central City. Oxford, University Press.

Linneman, P. (2004). Real Estate Finance \& Investments: Risks and Opportunities. Philadelphia, Linneman Associates.

Lipietz, A. (1977). Le capital et son espace. Paris, Maspéro.

Lipietz, A. (1987). Mirages and Miracles: The Crises of Global Fordism. London, Verso.

Lipietz, A. (1994). "The National and the Regional: Their Autonomy vis-à-vis the Capitalist World Crisis." Transcending the State-Global Divide. R. Palan and B. Gills. Boulder, Lynne Rienner Publishers: 23-44.

Lundqvist, L. (1992). "Dislodging the Welfare State? Housing and Privatisation in Four European Nations." Housing and Urban Policy Studies, 3. Delft, Delft University Press. 
MacLeod, G. (1997). "Globalizing Parisian Thought-Waves: Recent Advances in the Study of Social Regulation, Politics, Discourse and Space." Progress in Human Geography 21(4): 530-553.

MacLeod, G. (2002). "From Urban Entrepreneurialism to a "Revanchist City"? On the Spatial Injustices of Glasgow's Renaissance." Antipode 34(3): 602-624.

MacLeod, G. and Goodwin, M. (1999). "Space, Scale and State Strategy: Rethinking Urban and Regional Governance." Progress in Human Geography 23(4): 503-527.

MacLeod, G., et al. (2003). "Negotiating the Contemporary City: Introduction." Urban Studies 40(9): 1655-1671.

Marcuse, P. (1986). "Abandonment, Gentrification, and Displacement: The Linkages in New York City." Gentrification of the City. N. Smith and P. Williams. Boston, Allen \& Unwin: 153-177.

Marcuse, P. (1998). "Reflections on Berlin: The Meaning of Construction and the Construction of Meaning." International Journal of Urban and Regional Research 22(2): 331-338.

Marcuse, P. (1999). "Reply to Campbell and Häußermann." International Journal of Urban and Regional Research 23(1): 185-187.

Marston, S. A. (2000). "The Social Construction of Scale." Progress in Human Geography 24(2): 129-242.

Massey, D. (1979). "In What Sense a Regional Problem?" Regional Studies 13(2): 233-243.

Massey, D. (1984). Spatial Division of Labour. Social Structures and the Geography of Production. London, Macmillan.

Massey, D. (2004). "Uneven Development: Social Change and Spatial Division of Labor." Reading Economic Geography. T. J. Barnes, J. Peck, E. Sheppard and A. Tickell. Oxford, Blackwell: 111-124.

Massey, D. and Meegan, R. (1982). The Anatomy of Job Loss. London, Methuen.

Mayer, M. (1994). "Post-Fordist City Politics." Post-Fordism. A Reader. A. Amin. Oxford, Blackwell: 316-337.

McElligott, A. (1992). "Workers' Culture and Workers' Politics on Weimar's New Housing Estates: A Response to Adelheid von Saldern." Social History 17(1): 101113.

Meyer, M. (1995). "Urban Governance in the Post-Fordist City." Managing Cities: The New Urban Context. P. Healey, S. Cameron, S. Davoudi, S. Graham and A. Madani-Pour. Chichester, John Wiley \& Sons: 231-250.

Mitchell, D. (1997). "The Annihilation of Space by Law: The Roots and Implications of Antihomeless Laws in the United States." Antipode 29(3): 303-335. 
Müller, M. (2009). "Berliner Mietspiegel 2009. Kein Grund zur Entwarnung." MieterMagazin, Mieterverein Berlin. Juli/August 2009.

Murie, A. (1976). The Sale of Council Houses. Birmingham, University of Brimingham.

Myrdal, G. (1960). Beyond the Welfare State. Economic Planning in the Welfare States and Its International Implications. London, Yale University Press.

Norton, A. and Novy, K., Eds. (1991). Low Income Housing in Britain and Germany. London, Anglo-German Foundation.

Novy, K. (1991). "Housing Policy in West Germany: Winners and Losers in the Deregulation Battle." Low Income Housing in Britain and Germany. A. Norton and K. Novy. London, Anglo-German Foundation: 17-39.

Oellerich, J. (2011). "Erst abgezockt, dann verscherbelt: Die Destruktion der kommunalen Wohnungswirtschaft in Berlin - vor der rot-roten Koalition." Retrieved 03.03.2011, 2011, from http://www.bmgev.de/politik/wohnungspolitik/berliner-wohnungspolitik-2.html.

Offe, C. (1974). "Structural Problems of the Capitalist State." German Political Studies 1: 31-57.

Painter, J. (1998). "Entrepreneurs Are Made, Not Born: Learning and Urban Regimes in the Production of Entrepreneurial Cities." The Entrepreneurial City. Geographies of Politics, Regime and Representation. T. Hall and P. Hubbard. Chichester, John Wiley \& Sons Ltd: 259-274.

Painter, J. and Goodwin, M. (1995). "Local Governance and Concrete Research: Investigating the Uneven Development of Regulation." Economy and Society 24(3): 334-356.

Park, B.-G. (2008). "Uneven Development, Inter-scalar Tensions, and the Politics of Decentralization in South Korea." International Journal of Urban and Regional Research 32(1): 40-59.

Patton, M. Q. (2002). Qualitative Research \& Evaluation Methods. London, Sage.

Peck, J. (2002). "Political Economies of Scale: Fast Policy, Interscalar Relations, and Neoliberal Workfare." Economic Geography 78(3): 331-360.

Peck, J. (2003). "Geography and Public Policy: Mapping the Penal State." Progress in Human Geography 27(2): 222-232.

Peck, J. and Tickell, A. (1994). "Searching for a New Institutional Fix: The afterFordist Crisis and Global-Local Disorder." Post-Fordism: A Reader. A. Amin. Oxford, Blackwell: 280-315.

Peck, J. and Tickell, A. (1995). "The Social Regulation of Uneven Development and the Collapse of Thatcherism." Environment and Planning A 27(1): 15-40. 
Pickvance, C. G. (1994). "Housing Privatization and Housing Protest in the Transition from State Socialism: A Comparative Study of Budapest and Moscow." International Journal of Urban and Regional Research 18(3): 433-450.

Piore, M. J. and Sabel, C. F. (1984). The Second Industrial Divide: Possibilities for Prosperity. New York, Basic Books.

Porter, M. E. (1998). "Clusters and the New Economics of Competition." Harvard Business Review(November-December): 77-90.

Power, A. and Mumford, K. (1999). "The Slow Death of Great Cities. Urban Abandonment or Urban Renaissance." York, Joseph Rowntree Foundation.

Pratt, A. C. (1994). Uneven Re-Production. Industry, Space and Society. Oxford, Elsevier Science.

Pratt, A. C. (1995). "Putting Critical Realism to Work: The Practical Implications for Geographical Research." Progress in Human Geography 19(1): 61-74.

Pratt, A. C. (2004). "Andrew Sayer." Key Thinkers on Space and Place. P. Hubbard, R. Kitchin and G. Valentine. London, Sage: 245-250.

Prein, G. and Kelle, U. (1995). "Introduction: Using Linkages and Networks for Qualitative Theory Building." Computer-aided Qualitative Data Analysis. U. Kelle, G. Prein and K. Bird. London, Sage: 62-68.

Priemus, H. and Dieleman, F. (1999). "Social Housing Finance in the European Union: Developments and Prospects." Urban Studies 36(4): 623-631.

Prokla (1998). "Special Theme Issue on 'S(t)andOrt Berlin'." Prokla 28(1): 1-138.

Puchta, D. and Koop, V. (2008). Wohnungsbau und Wirtschaftsförderung. Deutsche Geschichte am Beispiel der Investitionsbank Berlin. Berlin, berlin edition.

Quinn, B. (2005). "Arts Festivals and the City." Urban Studies 42(5/6): 927-943.

Ritchie, J. and Lewis, J., Eds. (2003). Qualitative Research Practice. A Guide for Social Science Students and Researchers. London, Sage.

Rodriguez, A., et al. (2001). "Uneven Redevelopment: New Urban Policies and Socio-Spatial Fragmentation in Metropolitan Bilbao." European Urban and Regional Studies 8(2): 161-178.

Rottke, N. (2004). Investitionen mit Real Estate Private Equity. Herleitung eines anreizkompatiblen Beteiligungsmodells unter Berücksichtigung der Transaktionskosten- und Agency-Theorie. Köln, European Business School.

Rudolph-Cleff, A. (1996). Wohnungspolitik und Stadtentwicklung. Ein deutschfranzösischer Vergleich. Basel, Birkhäuser Verlag.

Sassen, S. (1991). The Global City: New York, London, Tokyo. Princeton, Princeton University Press. 
Sayer, A. (1992). Method in Social Science. A Realist Approach. London, Routledge.

Sayer, A. (2000). Realism and Social Science. London, Sage.

Sayer, A. (2004). "Industry and Space: A Sympathetic Critique of Radical Research." Reading Economic Geography. T. J. Barnes, J. Peck, E. Sheppard and A. Tickell. Oxford, Blackwell: 29-47.

Schäche, W. (1999). "Stadtplanung und Wohnungsbau während der nationalsozialistischen Herrschaft: Zwischen Kriegsvorbereitung und 'totalem Krieg'." Wohnen in Berlin. 100 Jahre Wohnungsbau in Berlin. Arbeitsgemeinschaft der Berliner Wohnungsbaugesellschaften und der Investitionsbank Berlin. Berlin, Edition StadtBauKunst: 194-207.

Scharenberg, A., Ed. (2000). Berlin: Global City oder Konkursmasse? Eine Zwischenbilanz zehn Jahre nach dem Mauerfall. Berlin, Karl Dietz Verlag.

Scharenberg, A. and Bader, I. (2009). "Berlin's Waterfront Site Struggle." City 13(2): 325-335.

Schwenk, H. (2002). Lexikon der Berliner Stadtentwicklung. Berlin, Haude \& Spener.

Scott, A. J. (1988). "Flexible Production Systems and Regional Development: The Rise of New Industrial Spaces in North America and Western Europe." International Journal of Urban and Regional Research 12(2): 171-186.

Seale, C. (1999). "Quality in Qualitative Research." Qualitative Inquiry 5(4): 465-478.

Seiler, G. (1998). "Von Subventionsmentalitäten und Metropolenträumen. Wirtschaftspolitik in Berlin." Prokla 28(1): 25-39.

Senatsverwaltung für Finanzen (2004a). "Beteiligungsbericht 2004 - Geschäftsjahre 2002/2003 - Band 1." Berlin, Senatsverwaltung für Finanzen.

Senatsverwaltung für Finanzen (2004b). "Beteiligungsbericht 2004 - Geschäftsjahre 2002/2003 - Band 2." Berlin, Senatsverwaltung für Finanzen.

Senatsverwaltung für Finanzen (2010a). "Beteilgungsbericht 2010 - Band 1: Unternehmensdaten." Berlin, Senatsverwaltung für Finanzen.

Senatsverwaltung für Finanzen (2010b). "Beteilgungsbericht 2010 - Band 2: Lageberichte 2009 mit Erklärungen zum Berliner Corporate Governance Kodex." Berlin, Senatsverwaltung für Finanzen.

Senatsverwaltung für Finanzen (2010c). "Haushalt und Finanzen Berlins. Ein Überblick." Berlin, Senatsverwaltung für Finanzen.

Senatsverwaltung für Integration Arbeit und Soziales. (2009). "Auführungsvorschriften zur Gewährung von Leistungen gemäß § 22 SGB II und $\S \S 29$ und 34 SGB XII (AV-Wohnen)." Retrieved 17.07.2011, from http://www.berlin.de/sen/soziales/berliner-sozialrecht/land/av/av_wohnen.html. 
Senatsverwaltung für Justiz (1995). "Gesetz zur Sicherung von Belegungsbindungen (Belegungsbindungsgesetz - BelBindG)." BRV 234-2. Berlin, Senatsverwaltung für Justiz.

Senatsverwaltung für Stadtentwicklung. (2002, 30.04.2002). "Vollständiger Verzicht auf Fehlbelegungsabgabe." Retrieved 18.01.2011, from http://www.berlin.de/landespressestelle/archiv/2002/04/30/05079/.

Senatsverwaltung für Stadtentwicklung. (2005a, 15.12.2005). "Belegungsbindung aufgehoben." Retrieved 01.02.2011, from http://www.stadtentwicklung.berlin.de/aktuell/pressebox/archiv_volltext.shtml\%3F arch 0512/nachricht2127.html.

Senatsverwaltung für Stadtentwicklung (2005b). "Der Berliner Wohnungsmarkt. Bericht 2004." Berlin, Senatsverwaltung für Stadtentwicklung und Investitionsbank Berlin.

Senatsverwaltung für Stadtentwicklung (2005c). "Leitsätze zur Stadterneuerung für die Sanierungsgebiete in Berlin." Berlin, Senatsverwaltung für Stadtentwicklung.

Senatsverwaltung für Stadtentwicklung (2007a). "Neue Chance für 33 Kieze. Quartiersmanagement in Berlin." Berlin, Senatsverwaltung für Stadtentwicklung.

Senatsverwaltung für Stadtentwicklung. (2007b). "Wohnlagen zum Berliner Mietspiegel 2007." Retrieved 8.7.2010, from http://fbinter.stadtberlin.de/fb/index.jsp.

Senatsverwaltung für Stadtentwicklung (2008). "Berlin Digital Environmental Atlas. 06.07 Urban Structure (Edition 2008)." Berlin, Senatsverwaltung für Stadtentwicklung.

Senatsverwaltung für Stadtentwicklung. (2009). "Wohnlagen zum Berliner Mietspiegel 2009." Retrieved 8.10.2010, from http://fbinter.stadtberlin.de/fb/index.jsp.

Senatsverwaltung für Stadtentwicklung. (2010a). "Berlin Digital Envrionmental Atlas. 06.09 Urban Structural Density (Edition 2010)." Retrieved 1.11.2010, from http://www.stadtentwicklung.berlin.de/umwelt/umweltatlas/ei609.htm.

Senatsverwaltung für Stadtentwicklung. (2010b). "Stadterneuerungsgebiete. Übersicht und Entwicklung." Retrieved 15.02.2010, from http://www.stadtentwicklung.berlin.de/wohnen/stadterneuerung/de/einleitung.shtm 1.

Senatsverwaltung für Stadtentwicklung. (2010c). "Wohnberechtigungsschein (WBS)." Retrieved 31.03.2010, from http://www.stadtentwicklung.berlin.de/wohnen/mieterfibel/de/mf wbs.shtml.

Senatsverwaltung für Stadtentwicklung. (2011). "Wegfall der Anschlussförderung im sozialen Wohnungsbau." Retrieved 05.05.2011, from http://www.stadtentwicklung.berlin.de/wohnen/anschlussfoerderung/. 
Senatsverwaltung für Stadtentwicklung und Investitionsbank Berlin (2002). "Der Berliner Wohnungsmarkt. Entwicklung und Strukturen 1991-2000." Berlin, Senatsverwaltung für Stadtentwicklung und Investitionsbank Berlin.

Sewing, W. and Hannemann, C. (1999). "Wiederaufbau in der 'Viersektorenstadt'." Wohnen in Berlin. 100 Jahre Wohnungsbau in Berlin. Arbeitsgemeinschaft der Berliner Wohnungsbaugesellschaften und der Investitionsbank Berlin. Berlin, Edition StadtBauKunst: 208-221.

Sibley, D. (1995). Geographies of Exclusion. Society and Difference in the West. London, Routledge.

Simons, K. (2007). "Sanierung jetzt auf dem Weg." MieterMagazin (10): 11.

Smith, N. (1982). "Gentrification and Uneven Development." Economic Geography 58(2): 139-155.

Smith, N. (1984). Uneven Development: Nature, Capital and the Production of Space. Oxford, Blackwell.

Smith, N. (1996). The New Urban Frontier. Gentrification and the Revanchist City. London, Routledge.

Smith, N. (2002). "New Globalism, New Urbanism: Gentrification as Global Urban Strategy." Antipode 34(3): 427-450.

Stake, R. E. (2008). "Qualitative Case Studies." Strategies of Qualitative Inquiry. N. K. Denzin and Y. S. Lincoln. London, Sage: 114-150.

Statistische Ämter des Bundes und der Länder. (2008). "Verfügbares Einkommen je Einwohner in Deutschland 1991 bis 2007 nach Bundesländern." Retrieved 31.03.2010, from http://www.vgrdl.de/Arbeitskreis_VGR/tbls/tab14.asp.

Steinmetz, F. (2003). Wohnungsprivatisierung in den neuen Bundesländern unter besonderer Berücksichtigung ländlicher und verstädterter Räume. Eine Analyse im Kontext europäischer Privatisierungsprogramme. Göttingen, Cuvillier Verlag.

Stephens, M., et al. (2008). "The Privatization of Social Housing: Three Different Pathways." Social Housing in Europe II. A Review of Policies and Outcomes. K. Scanlon and C. Whitehead. London, London School of Economics and Political Science: $105-130$.

Stimpel, R. (1990). Der verbaute Markt. Villenglück und Wohnungsnot. Frankfurt am Main, Fischer Taschenbuch Verlag GmbH.

Stoker, G. (1995). "Regime Theory and Urban Politics." Theories of Urban Politics. D. Judge and H. Wolman. London, Sage Publication: 54-71.

Stone, C. N. (1989). Regime Politics: Governing Atlanta, 1946-1988. Lawrence, University Press of Kansas. 
Stone, C. N. (2004). "It's More than the Economy after All: Continuing the Debate about Urban Regimes." Journal of Urban Affairs 26(1): 1-19.

Storper, M. and Scott, A. J. (1992). Pathways to Industrialization and Regional Development. London, Routledge.

Strom, E. (2001). Building the New Berlin: The Politics of Urban Development in Germany's Capital City. Lanham, Lexington Books.

Struyk, R. J., Ed. (1996a). Economic Restructuring of the Former Soviet Bloc: The Case of Housing. Washington D.C., The Urban Institute Press.

Struyk, R. J. (1996b). "Housing Privatization in the Former Soviet Bloc to 1995." Cities After Socialism. Urban and Regional Change and Conflict in Post-Socialist Societies. G. Andrusz, M. Harloe and I. Szelenyi. Oxford, Blackwell: 192-213.

Swyngedouw, E. (1992). "The Mammon Quest: "Glocalisation", Interspatial Competition and the Monetary Order: The Construction of New Scales." Cities and Regions in the New Europe: the Global-Local Interplay and Spatial Development Strategies. M. Dunford and G. Kafkalas. London, Belhaven Press: 39-68.

Swyngedouw, E. (1997). "Neither Gobal Nor Local: "Glocalization" and the Politics of Scale." Spaces of Globalization: Reasserting the Power of the Local. K. R. Cox. New York, Guilford Press: 137-166.

Swyngedouw, E. (2000). "Authoritarian Governance, Power, and the Politics of Rescaling." Environment and Planning D: Society and Space 18(1): 63-76.

Swyngedouw, E., et al. (2002). "Neoliberal Urbanization in Europe: Large-Scale Urban Development Projects and the New Urban Policy." Antipode 34(3): 542-577.

Tickell, A. and Peck, J. (1992). "Accumulation, Regulation and the Geographies of Post-Fordism: Missing Links in Regulationist Research." Progress in Human Geography 16(2): 190-218.

Tickell, A. and Peck, J. (1995). "Social Regulation after Fordism: Regulation Theory, Neo-liberalism and the Global-Local Nexus." Economy and Society 24(3): 357-386.

Tickell, A. and Peck, J. (1996). "The Return of the Manchester Men: Men's Words and Men's Deeds in the Remaking of the Local State." Transactions of the Institute of British Geographers, New Series 21(4): 595-616.

Turner, B. and Whitehead, C. (2002). "Reducing Housing Subsidy: Swedish Housing Policy in an International Context." Urban Studies 39(2): 201-217.

Van Kempen, R. and Priemus, H. (2002). "Revolution in Social Housing in the Netherlands: Possible Effects of New Housing Policies." Urban Studies 39(2): 237-253.

Wacquant, L. (2000). "The Coming of the Penal State Is Not Inevitable." Working Papers in Local Governance and Democracy 4. Berkeley, University of California at Berkeley. 
Ward, K. (2003). "Entrepreneurial Urbanism, State Restructuring and Civilizing 'New East Manchester'." Area 35(2): 116-127.

Weber, R. (2002). "Extracting Value from the City: Neoliberalism and Urban Redevelopment." Antipode 34(3): 519-540.

Wengraf, T. (2001). Qualitative Research Interviewing. Biographic Narrative and Semi-Structured Methods. London, Sage.

Whitehead, C. (1999). "The Provision of Finance for Social Housing: The UK Experience." Urban Studies 36(4): 657-672.

Whitehead, C. (2007). "Planning Policies and Affordable Housing: England as a Successful Case Study?" Housing Studies 22(1): 25-44.

Whitehead, C. and Scanlon, K., Eds. (2007). Social Housing in Europe. London, London School of Economics and Political Science.

Whitehead, C. M. E. (1993). "Privatizing Housing: An Assessment of U.K. Experience." Housing Policy Debate 4(101-139).

Winograd, B. (2004). "US Pension Funds and Real Estate: Still Crazy after all These Years." International Real Estate. An Institutional Approach. W. Seabrooke, P. Kent and H. Hwee-Hong How. Oxford, Blackwell Publishing: 200-219.

Wissen, M. and Naumann, M. (2008). "Die Dialektik von räumlicher Angleichung und Differenzierung: Zum uneven-development-Konzept in der radical geography." ACME: An International E-Journal for Critical Geographies 7(3): 377-407.

Wood, A. (1998). "Making Sense of Urban Entrepreneurialism." Scottish Geographical Journal 114(2): 120-123.

Wowereit, K. and Junge-Reyer, I. (2007). "Vorlage - Zur Kenntnisnahme Gesamtkonzept für die Städtischen Wohnungsbaugesellschaften in Berlin." Abgeordnetenhaus Berlin. Drucksache 16-0747, 11.07.2007.

Yeung, H. W.-C. (1997). "Critical Realism and Realist Research in Human Geography: A Method or a Philosophy in Search of a Method?" Progress in Human Geography 21(1): 51-74.

Yin, R. K. (1994). Case Study Research. Design and Methods. London, Sage.

Zingel, M. (2006). "Analyse der Real Estate Private Equity Investments in Deutschland." Fachbereich Betriebswirtschaft. Kaiserslautern, Fachhochschule Kaiserslautern. Diplom. 